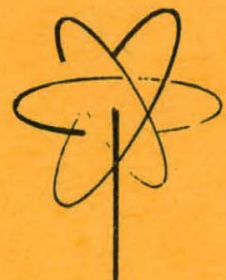

High PERFormanCE $\mathrm{UO}_{2}$ PRogram IRRADIATION OF 0.5 INCH DIAMETER, SOLID PELLET UO ${ }_{2}$ FUEL RODS AT 700,000 Btu/h-ft ${ }^{2}$ PEAK HEAT FLUX

M.F. LYONS

R.C. NELSON

T.J. PASHOS

C.R. WILSON

B. WEIDENBAUM

U.S. ATOMIC ENERGY COMMISSION CONTRACT AT(04-3)-189

PROJECT AGREEMENT 17

ATOMIC POWER EQUIPMENT DEPARTMENT

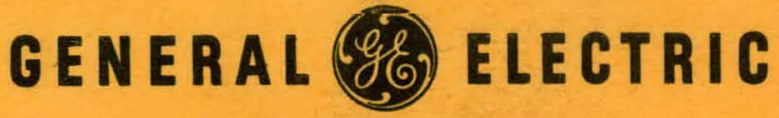

SAK JOSE, CALIFORNIA 


\section{DISCLAIMER}

This report was prepared as an account of work sponsored by an agency of the United States Government. Neither the United States Government nor any agency Thereof, nor any of their employees, makes any warranty, express or implied, or assumes any legal liability or responsibility for the accuracy, completeness, or usefulness of any information, apparatus, product, or process disclosed, or represents that its use would not infringe privately owned rights. Reference herein to any specific commercial product, process, or service by trade name, trademark, manufacturer, or otherwise does not necessarily constitute or imply its endorsement, recommendation, or favoring by the United States Government or any agency thereof. The views and opinions of authors expressed herein do not necessarily state or reflect those of the United States Government or any agency thereof. 


\section{DISCLAIMER}

Portions of this document may be illegible in electronic image products. Images are produced from the best available original document. 
THIS PAGE

WAS INTENTIONALLY

LEFT BLANK 
LEGAL NOTICE

THIS DOCUMENT WAS PREPARED UNDER THE SPONSORSHIP OF THE ATOMIC ENERGY COMMISSION PURSUANT TO THE JOINT RESEARCH AND DEVELOPMENT PROGRAM ESTABLISHED BY THE AGREEMENT FOR COOPERATION SIGNED NOVEMBER 8, 1958, BETWEEN THE GOVERNMENT OF THE UNITED STATES OF AMERICA AND THE EUROPEAN ATOMIC ENERGY COMMUNITY (EURATOM). NEITHER THE UNITED STATES, THE U.S. ATOMIC ENERGY COMMISSION, THE EUROPEAN ATOMIC ENERGY COMMUNITY, THE EURATOM COMMISSION, NOR ANY PERSON ACTING ON BEHALF OF EITHER COMMISSION:

A. MAKES ANY WARRANTY OR REPRESENTATION, EXPRESS OR IMPLIED, WITH RESPECT TO THE ACCURACY, COMPLETENESS, OR USEFULNESS OF THE INFORMATION CONTAINED IN THIS DOCU MENT, OR THAT THE USE OF ANY INFORMATION, APPARATUS, METHOD, OR PROCESS DISCLOSED IN THIS DOCUMENT MAY NOT INFRINGE PRIVATELY OWNED RIGHTS; OR

B. ASSUMES ANY LIABILITIES WITH RESPECT TO THE USE OF, OR FOR DAMAGES RESULTING FROM THE USE OF ANY INFORMATION, APPARATUS, METHOD OR PROCESS DISCLOSED IN THIS DOCUMENT.

AS USED IN THE ABOVE, "PERSON ACTING ON BEHALF OF EITHER COMMISSION" INCLUDES ANY EMPLOYEE OR CONTRACTOR OF EITHER COMMISSIONOR EMPLOYEE OF SUCH CONTRACTOR TO THE EXTENT THAT SUCH. EMPLOYEE OR CONTRACTOR OR EMPLOYEE OF SUCH CONTRACTOR PREPARES, HANDLES, DISSEMINATES, OR PROVIDES ACCESS TO, ANY INFORMATION PURSUANT TO HIS EMPLOYMENT OR CONTRACT WITH EITHER COMMISSION OR HIS EMPLOYMENT WITH SUCH CONTRACTOR.

To expedite dissemination of technical information to. those persons requiring it, this report has been issued without the administrative review necessary to protect the interest of the U.S. Government, the European Atomic Energy Community (Euratom) and the contractor. The recipient of this report agrees that it is passed on to him in confidence, that he will maintain that confidence and make no disclosures or publication of the contents, that would be detrimental to the in-

tcrests of the U.S. Government, the European Atomic Energy Community (Euratom) and the contractor.

L N 5 


\section{PREFACE}

This report is one of a series describing the individual fuel assemblies irradiated during the U.S. Atomic Energy Commission - Euratom sponsored High Performance $\mathrm{UO}_{2}$ Program $^{\circ}$ at the General Electric Company, Atomic Power Equipment Department. The report series is considered an Appendix to the final summary report on the program. All of the High Performance $\mathrm{UO}_{2}$ Program final summary reports will be issued under the single report number GEAP-5100. Major topics in the final report will be designated by the sequence GEAP-5100-1, 5100-2, 5100-3, etc. Sections of the Appendix will follow the sequence GEAP-5100-A, 5100-B, 5100-C etc. 


\section{ABSTRACT}

The fabrication data, ir radiation history, and the complete, correlated post-irradiation examination results are described for a four-rod fuel assembly - designated EPT-6* - that operated in the GETR-PWL** with slight central melting to a burnup of $\sim 1200 \mathrm{MWD} / \mathrm{Te}$. The fuel rods were unsegmented, reactor-length rods containing 95 percent dense, solid, sintered $\mathrm{UO}_{2}$ pellets in freestanding Zircaloy-2 cladding. This fuel assembly was the first of a series irradiated to investigate the feasibility and limitations in $\mathrm{UO}_{2}$ fuel-rod operation with central melting. Post-irradiation examination of this assembly provided the first indication of the basic obstacle to operation with central melting; namely, severe, localized clad swelling accompanying the onset of central melting in high density fuel. Later work proved that the clad swelling resulted from the $\mathrm{UO}_{2}$ phase change volume expansion and could be corrected by proper fuel rod design. This later work and the results and conclusions from the entire series of pellet fuel assembly irradiations, including EPT-6, have been described earlier in GEAP- 4264.

*EPT-6 designates Euratom pellet as sembly, 600,000 Btu/h-ft ${ }^{2}$ nominal peak heat flux.

**GETR-PWL - General Electric Test Reactor - Pressurized Water Loop 


\section{TABLE OF CONTENTS}

PREFACE

iii

ABSTRACT

iv

INTRODUCTION

IRRADIATION HISTORY

POST IRRADIATION EXAMINATION EPT-6 5

FABRICATION AND PERFORMANCE DATA OF EPT- $6 \quad 8$

GAMMA SCAN RESULTS

SECTION VI PHOTOGRAPHIC ANALYSIS

A. Rod 6-A

1. Fracture Sections 18

2. Peak Heat Flux Zone 30

3. Maximum Burnup Zone 37

B. Rod 6-D

1. Fracture Sections 47

2. Peak Heat Flux Zone 70

3. Maximum Burnup Zone 92

4. Other Sections - Prepared for Fission Product Migration Studies 101

SECTION VII ACKNOWLEDGMENTS 132 


\section{ILLUSTRATIONS}

No.

1

2

3

4

5

6

8

9
Title

EPT-6 Thermal Performance History

Dimensional Changes EPT- 6

Fuel Assembly Design

Assembly Pre-Irradiation Appearance

Fuel Rod Design

Gamma Scans - EPT-6

(Photos of Rod 6-A)
Page

4

6

13

14

15

17

$6 / 24$

46

$25 / 96$

130

131 


\section{TABLES}

No.

Title

$\underline{\text { Page }}$

1

Coolant Conditions

Chemical Analysis - $\mathrm{UO}_{2}$ Ceramic Grade Powder

3

Chemical Analysis - $\mathrm{UO}_{2}$ Sintered Pellets

Physical and Chemical Properties - Annealed Zircaloy Tubing 


\section{$\underline{\text { INTRODUCTION }}$}

In 1961 an experimental program was undertaken at the General Electric Atomic Power Equipment Department to systematically explore the feasibility and limitations in $\mathrm{UO}_{2}$ fuel rod operation with central melting. The program was jointly sponsored by the U.S. Atomic Energy Commission and Euratom. The basic experimental plan was to irradiate a series of identical (except for enrichment) fuel assemblies at progressively increasing thermal performance conditions, and consequent central melting, until a fuel rod failure occurred. Two separate irradiation series were performed, the first with pellet containing fuel rods and then a second with compacted $\mathrm{UO}_{2}$ powder. The irradiations were conducted in the GETR Pressurized Water Loop. Fuel assembly heat transfer during the irradiations were completely in the subcooled, forced convection cooled regime, without nucleate boiling.

The irradiation program was concluded in October, 1964, with the successful irradiation of a fuel assembly containing both powder and pellet fuel rods to high burnup, while operating continuously with gross central melting. The results from the initial pellet irradiation series have been summarized in a final report (GEAP-4264) and summary reports are in preparation describing the powder fuel irradiation series and the final, high burnup assembly performance. However, these summary reports are necessarily incomplete regarding the individual assembly irradiation results and concerned primarily with the results and conclusions from the series as a whole. One of the most valuable assets of the program is the detailed post-irradiation examination data on the individual fuel rods. Since this program is the only known systematic investigation of central melting using reactor length fuel rods, these data are believed to be of outstanding technical interest and significance and should prove worthwhile for other investigators to analyze and interpret. To provide a permanent record and convenient reference to these results, a separate report is being prepared on each fuel assembly irradiated during the program. This report describes the correlated fabrication, irradiation and post-irradiation examination data from the first pellet fuel assembly irradiated -. Assembly EPT-6. This initial pellet assembly was designed to undergo slight central melting at the maximum axial power position. 


\section{IRRADIATION HISTORY}

The fuel rods in Assembly EPT-6 contained 1.5\% enriched $\mathrm{UO}_{2}$ fuel pellets and were intended to operate at a nominal peak heat flux of $600,000 \mathrm{Btu} / \mathrm{h}-\mathrm{ft}^{2}\left(190 \mathrm{w} / \mathrm{cm}^{2}\right)$. The following actual conditions obtained at initial; $30 \mathrm{MW}(\mathrm{th})$ reactur power operation were:

Start-up Date - 4/23/62

General Electric Test Reactor (GETR) Cycle No. - 33

Control Rod Bank Position - 19.3 in. $(49 \mathrm{~cm})$

Assembly Average, Peak Heat Flux - 680,000 Btu/h-ft ${ }^{2}\left(214 \mathrm{w} / \mathrm{cm}^{2}\right)$

Rod 6A Peak Surface Heat Flux $-628,000 \mathrm{Btu} / \mathrm{h}-\mathrm{ft}^{2}\left(198 \mathrm{w} / \mathrm{cm}^{2}\right)$

Rod 6D Peak Surface Heat Flux $-734,000 \mathrm{Btu} / \mathrm{h}-\mathrm{ft}^{2}\left(232 \mathrm{w} / \mathrm{cm}^{2}\right)$

The coolant conditions during the EPT-6 assembly irradiation are listed in Table 1 . The assembly operated satisfactorily for the entire 25 - day GETR Cycle 33 and experienced 6 full power cycles. The average thermal power of the assembly during operation was $200 \mathrm{~kW}$. The GETR was refueled on May 10, 1962 which lowered the control rod bank position from 28.4 inches $(72 \mathrm{~cm})$ before refueling to 25.6 inches $(65 \mathrm{~cm})$ after refueling. The chronological variation in average heat flux of Rod.6D during the cycle is shown in Figure 1.

The dates and approximate times of the 5 interim shut-downs are as follows:

$\begin{array}{lll}\text { No. } 1 & 24 \text { April } 1962 & 1000-2200 \mathrm{~h} \\ \text { No. } 2 & 26 \text { April } 1962 & 1420-1430 \mathrm{~h} \\ \text { No. } 3 & 28 \text { April } 1962 & 1510-1525 \mathrm{~h} \\ \text { No. } 4 & 10 \text { May }-11 \text { May 1962 } & 2050-1130 \mathrm{~h} \\ \text { No. } 5 & 13 \text { May } 19662 & 1730-1015 \mathrm{~h}\end{array}$

The following conditions prevailed at $30 \mathrm{MW}$ (th) reactor power immediately before the final shut-down:

Shut-Down Date - 5/19/62

Control Rod Bank Position - 31.5 in. $(80 \mathrm{~cm})$

Assembly Average, Peak Heat Flux $-560,000 \mathrm{Btu} / \mathrm{h}-\mathrm{ft}^{2}\left(177 \mathrm{w} / \mathrm{cm}^{2}\right)$

Rod 6-D Peak Heat Flux - 605, $000 \mathrm{Btu} / \mathrm{h}-\mathrm{ft}^{2}\left(191 \mathrm{w} / \mathrm{cm}^{2}\right)$

Assembly Average Burnup - $1250 \mathrm{MWD} / \mathrm{T}_{\mathrm{e}}\left(0.34 \times 10^{20}\right.$ fissions $\left./ \mathrm{cm}^{3}\right)$ 
Pressure

Saturation Temperature

Fuel Assembly Temperatures:

Inlet

Outlet

Flow Velocity at Fuel Rods

Mass Velocity

Flow Rate

pH (LiOH Regenerated Demineralized)

Dissolved $\mathrm{H}_{2}$

Crud Deposition

Cooling Regime

Film Heat Transfer

Coefficient

Density

Specific Heat
1000 psia

$545^{\circ} \mathrm{F}$

$344^{\circ} \mathrm{F}$

$370^{\circ} \mathrm{F}$

$16 \mathrm{ft} / \mathrm{sec}$

$3.22 \times 10^{6} \mathrm{lb} / \mathrm{h}-\mathrm{ft}^{2}$

$57 \mathrm{gal} / \mathrm{min}$

9.5 to 10.0

25 to $65 \mathrm{cc} / \mathrm{kg}$

None

Forced Convection (Without Nucleate Boiling)

$7,100\left(\mathrm{Btu} / \mathrm{h}-\mathrm{ft}^{2}-{ }^{\circ} \mathrm{F}\right)$

$56 \mathrm{lb} / \mathrm{ft}^{3}$

$1.05 \mathrm{Btu} / \mathrm{lb}-{ }^{\circ} \mathrm{F}$

*For a More Detailed Description see GEAP-4264 


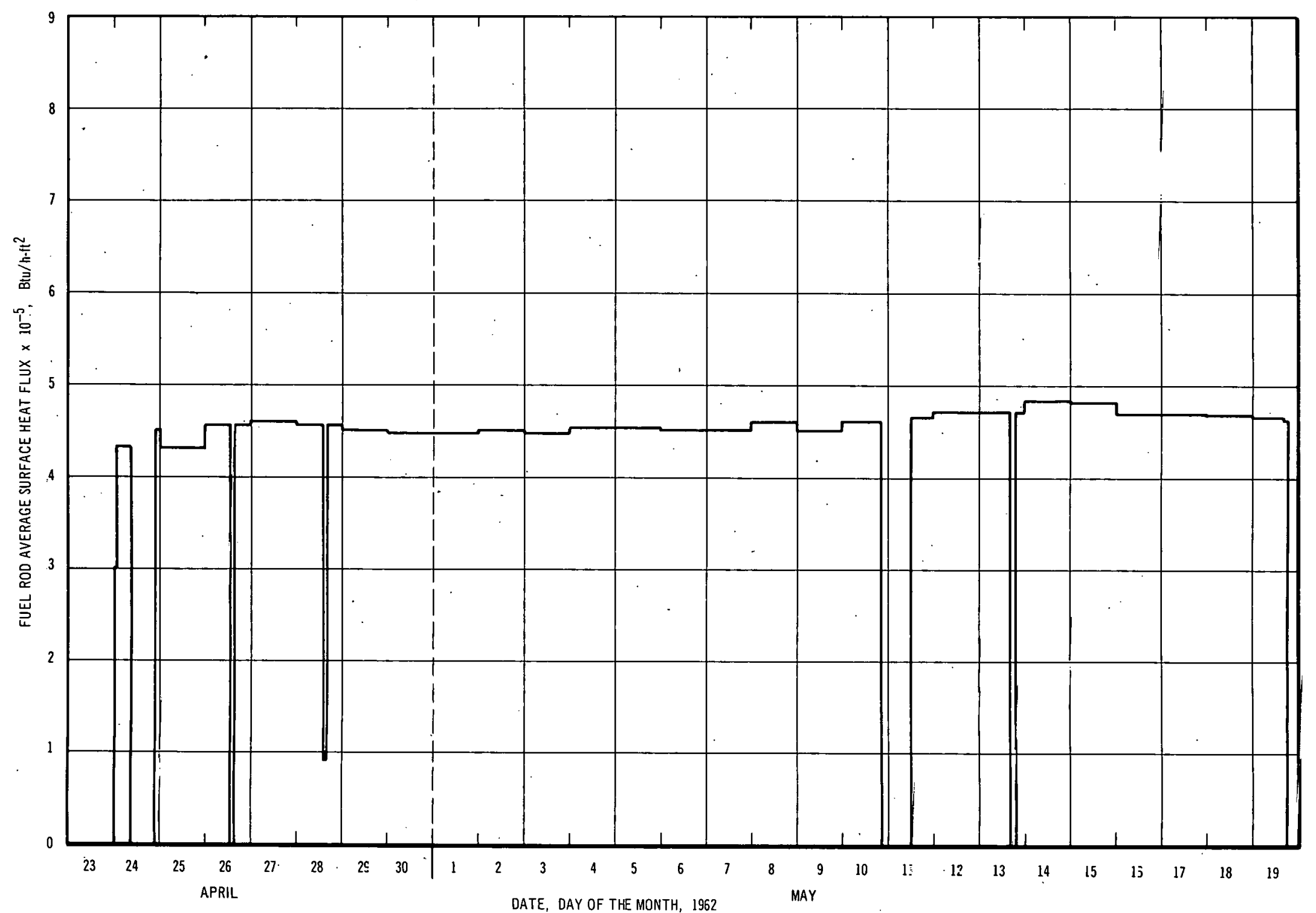


When assembly EPT-6 was initially examined in the RML, only rod 6A was easily removed from its shroud tube. After considerable physical effort, rod 6B was withdrawn from its shroud tube but the rod surface was badly scarred by the lateral spacers in the process. Neither rod 6C nor $6 \mathrm{D}$ could be withdrawn and it was necessary to slit the shroud tubes full length to effect removal. Subsequent dimensional examination revealed severe clad swelling in rods $6 \mathrm{C}$. and $6 \mathrm{D}$. Rod $6 \mathrm{~B}$ was slightly swollen and $6 \mathrm{~A}$ was. just perceptibly swollen. The dimensional increase of $6 \mathrm{~A}$ was less than the experimental measurement accuracy and may not be significant. Figure 2 illustrates the diameter changes in the EPT -6 assembly fuel rods as a function of axial position. The dark shaded areas on the plots shown in Figure 2, indicate the differences in the diameter measurements at 0 and 90 degree rotational orientations of the fuel rods. It is evident that the clad swelling is almost perfectly symmetrical and is confined to a very short, 4 inch axial section of the rods, centered at a position approximately 9 inches above the bottom end of the fuel rod. This axial position corresponds to the peak heat flux location at start-up which indicates clad swelling occurred at startup.

The maximum diameter increase occurred in rod 6D and was $47 \mathrm{mils}$ or an approximately $8 \%$ circumferential elongation of the cladding. Based on its integrated gamma activity, determined during gamma scanning, rod $6 \mathrm{D}$ was also the maximum power rod in the assembly. This result coupled with the axial location of the swelling indicated strongly that the clad swelling was related to thermal performance level of the fuel rod (see Figure 8). In Table 2, the pre- and postirradiation measurements of assembly EPT -6 are summarized.

The visual appearance of the rods $6 \mathrm{C}$ and $6 \mathrm{D}$ was generally identical to the pre-irradiation condition except at the location of the swelling. At this location, the rod surfaces were badly scored from the lateral spacers during the initial attempt to remove them from their shroud tubes. Rod 6D was selected for destructive examination because it was the maximum power rod and also the rod with the maximum diameter increasc. Subsequently, rod $6 \mathrm{~A}$ was also destructively examined for comparision. 

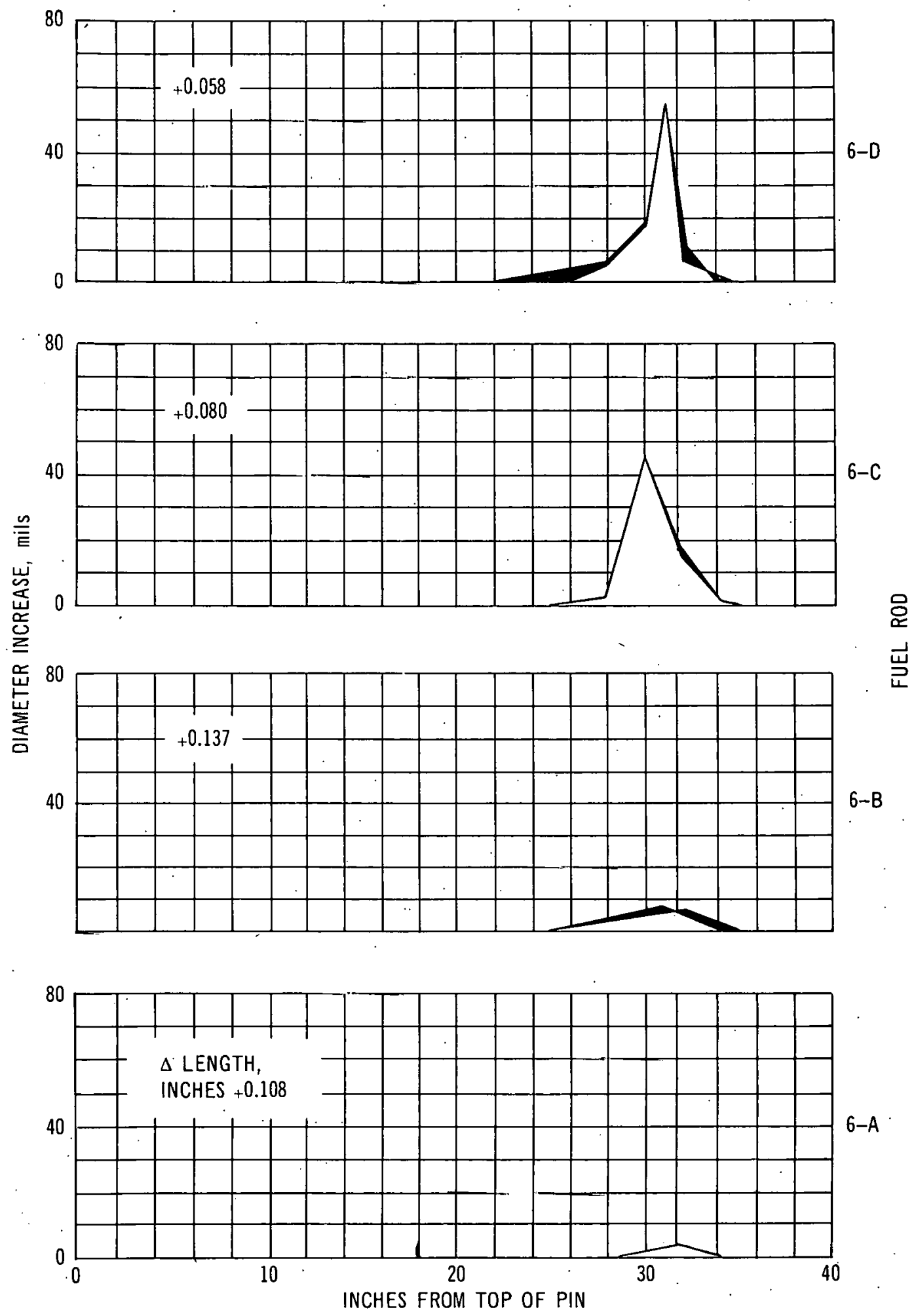

Figure 2 Dimensional Changes - Assembly EPT-6 
TABLE 2. Assembly EPT-6 Pre- and Post-Irradiation Dimensions.

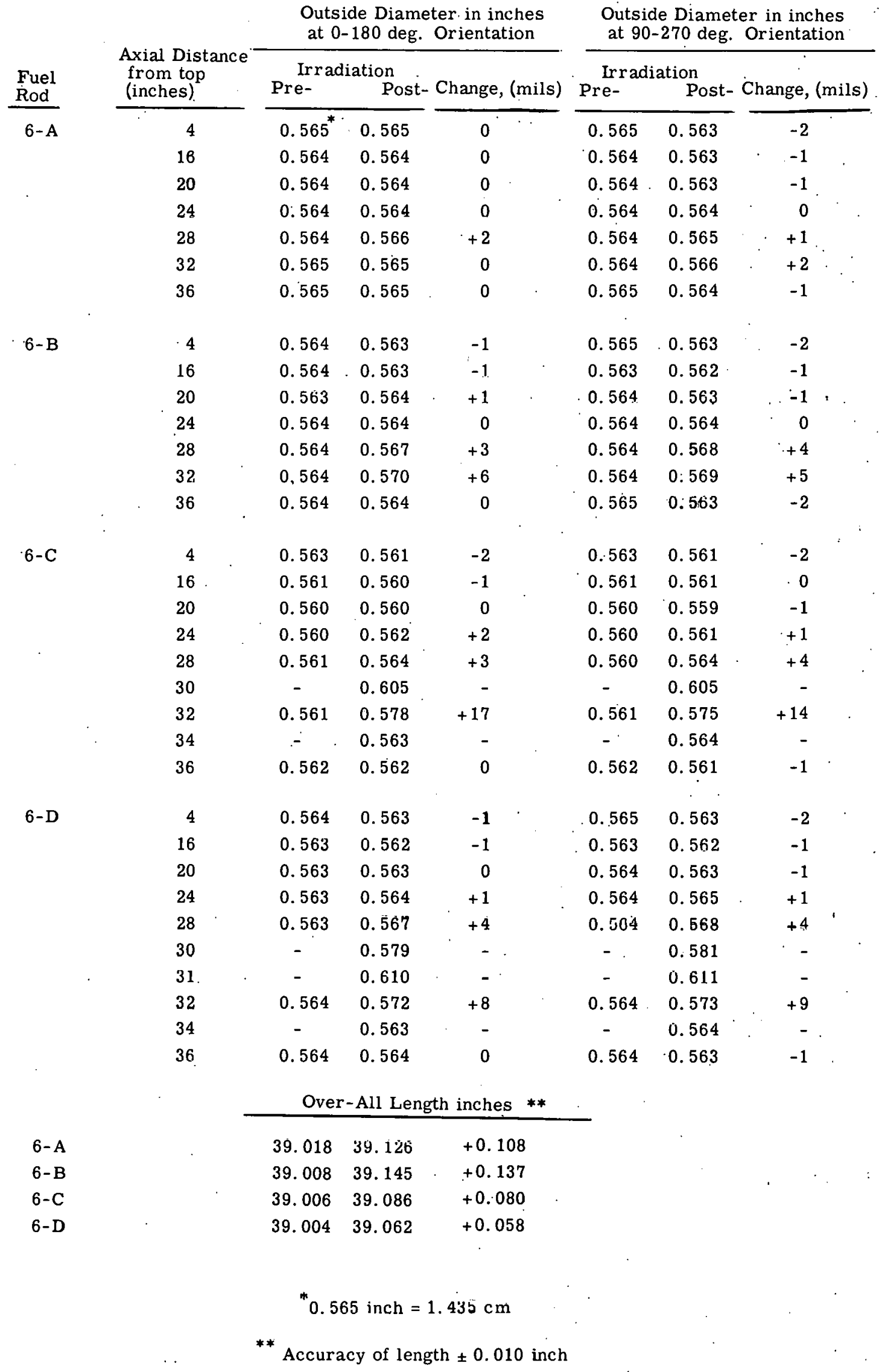


TABLE 3

CHEMICAL ANALYSTS OF $1.5 \%$ ENRICHED

$\mathrm{UO}_{2}$ CERAMIC GRADE POWDER

Element

$\mathrm{Al}$

B

$\mathrm{Cd}$

$\mathrm{Ca}$

$\mathrm{C}$

$\mathrm{F}$

$\mathrm{Fe}$

$\mathrm{Si}$

$\mathrm{Cl}$

$\mathrm{Cr}$

$\mathrm{Cu}$

$\mathrm{Mn}$

$\mathrm{N}$

$\mathrm{V}$

$\mathrm{Ti}$

Co

Mo

$\mathrm{Ni}$

$\mathrm{Ag}$
Impurity Content, PPM

2

0.20

$<0.10$

26

43

49

10

4

$<25$

3

21

3

$<10$

$<10^{*}$

$<100^{*}$

$<5$

$<1 *$

10

$<0.10$
U:O Ratin

Particle Size, $\mu$

(Fisher Sub-Sieve)

Bulk Density, gm/cc $\mathrm{U}^{235}, \%$
2.07

0.93

1. 14

1. 497

*No Determination 
TABLE 4

CHEMICAL ANALYSIS $1.5 \%$ ENRICHED UO SINTERED PELLETS

Element

Al

$\mathrm{Bi}$

B

Cd

$\mathrm{Ca}$

$\mathrm{Cr}$

Co

$\mathrm{Cu}$

$\mathrm{Fe}$

$\mathrm{Pb}$

$\mathrm{Mg}$

$\mathrm{Mn}$

Mo

$\mathrm{Si}$

Ag

$\mathrm{Na}$

$\mathrm{Sn}$

$\mathrm{V}$

Zn

$\mathrm{Ni}$

$\mathrm{Sb}$

N

C

F

U:O Ratio

Density, \% $\mathrm{U}^{235}$
Impurity Content, PPM

20

$<1$

$<1<1$

$<0.2<0.2$

$<1 \quad<1$

$10 \quad 10$

$25 \quad 25$

$<2<2$

$65 \quad 65$

$500 \quad 200$

$<1<1$

$5 \quad 5$

$<1 \quad<1$

$10<3$

$30 \quad 30$

$3 \quad 10$

$<35<35$

$5 \quad 10$

$<15<15$

$<10<10$

$100 \quad 50$

$<2<2$

$160 \quad 390$

$<10<10$

$16 \quad 18$

$2.03,2.01,2.00$

94.1 to $97.3^{*}$

$1.46 \pm 0.04$

$1.50 \pm 0.04$

* Based on 15 Pellets 
TABLE 5. Physical-Chemical Properties, Annealed Zircaloy Tubing

Ingot No. 28601, Lot No. 494

Corrosion Weight Gain -15.8 and $15.5 \mathrm{mg} / \mathrm{dm}^{2}$ in 3 days at $750^{\circ} \mathrm{F}, 1500$ psi steam $\left(399^{\circ} \mathrm{C}\right.$, $605 \times 10^{6} \mathrm{~kg} / \mathrm{m}^{2}$.)

Chemical Analysis:

\begin{tabular}{cl} 
Alloy Elements & \multicolumn{1}{c}{$\%$} \\
\cline { 2 - 2 } $\mathrm{Sn}$ & 1.53 \\
$\mathrm{Fe}$ & 0.132 \\
$\mathrm{Cr}$ & 0.103 \\
$\mathrm{Ni}$ & 0.054 \\
$\mathrm{Fe}+\mathrm{Cr}+\mathrm{Ni}$ & 0.289
\end{tabular}

Imputity, ppm

$\begin{array}{lc}\mathrm{Al} & 29 \\ \mathrm{~B} & <0.3 \\ \mathrm{C} & 172 \\ \mathrm{Ca} & <20 \\ \mathrm{Cd} & <20 \\ \mathrm{Cl} & <20 \\ \mathrm{Co} & <5 \\ \mathrm{Cu} & <20\end{array}$

Impurity, ppm

Hf $\quad 79$

$\mathrm{Mg}<20$

$\mathrm{Mn}<20$

Mo $\quad<20$

$\mathrm{Na}<20$

$\mathrm{Pb}<20$

$\mathrm{Si} \quad 35$

$\mathrm{Ti} \quad<20$
Impurity, ppm

$\begin{array}{lc}\mathrm{V} & <20 \\ \mathrm{~W} & <20 \\ \mathrm{U} & <0.2 \\ & \\ \mathrm{H} & 17 \\ \mathrm{~N} & 23 \\ \mathrm{O} & 910\end{array}$

Longitudinal Mechanical Properties:

Ultimate Tensile Strength, $\mathrm{ksi}\left(\mathrm{kg} / \mathrm{m}^{2}\right)$

Yield Strength $(0.2 \%$ offset $) \mathrm{ksi},\left(\mathrm{kg} / \mathrm{m}^{2}\right)$

Elongation in 2 inches $(5 \mathrm{~cm}), \%$

Hardness (Ruckwell D)

Grain Size: $\quad$ ASTM 6-7

Flare Test: $\quad 33.6 \%$ and $34.4 \%$ o.d. expansion at 60 degrees

Burst Test: 10,500 -psi yield pressure, $\left(7.4 \times 10^{6} \mathrm{~kg} / \mathrm{m}^{2}\right)$

11,000 -psi burst pressure, $\left(7.7 \times 10^{6} \mathrm{~kg} / \mathrm{m}^{2}\right)$ $84.1\left(59.0 \times 10^{6}\right)$

$65.0\left(45.6 \times 10^{6}\right)$

16.5

$81.1\left(57.0 \times 10^{6}\right)$

$63.9\left(44.8 \times 10^{6}\right)$

17.7

$92.0 / 93.0$

$91.5 / 93.0$ 
TABLE 6

EPT-6 ASSEM BLY CHARACT ERISTICS AND HISTORY

Fuel Enrichment

\section{Fuel Type}

Average Fuel Col. Length

Assembly Thermal Power

Irradiation Period

Number of Rods with C lad

Swelling

Maximum Rod Diameter

Increase

Surface Heat Flux:

Nominal for Ept 6

At Startup:

Assembly Average

6A Peak

6D Peak

At Shutdown:

Assembly Average

6A Peak

6D Peak

Assembly Average Burn-up
$1.5 \%$

Pellet, Solid

$34 \pm 1 / 4$ in.

$200 \mathrm{~kW}$

$4 / 23 / 62$ through $5 / 19 / 62$

3

47 mils.

$600,000 \mathrm{Btu} / \mathrm{h}-\mathrm{ft}^{2}$

$680,000 \mathrm{Btu} / \mathrm{h}-\mathrm{ft}^{2}$

$628,000 \mathrm{Btu} / \mathrm{h}-\mathrm{ft}^{2}$

734, $000 \mathrm{Btu} / \mathrm{h}-\mathrm{ft}^{2}$

$560,000 \mathrm{Btu} / \mathrm{h}-\mathrm{ft}^{2}$

$515,000 \mathrm{Btu} / \mathrm{h}-\mathrm{ft}^{2}$

$600,000 \mathrm{Btu} / \mathrm{h}-\mathrm{ft}^{2}$

$1250 \mathrm{MWD} / \mathrm{T}_{\mathrm{e}}$ 
TABLE 7

FUEL ROD DATA

\begin{tabular}{|c|c|c|c|c|}
\hline Rod - EPT - & $6 \mathrm{~A}$ & $6 \mathrm{~B}$ & $6 \mathrm{C}$ & $6 \mathrm{D}$ \\
\hline \multicolumn{5}{|l|}{ Cladding Diameter, in } \\
\hline Outside & $0.5647-0.5653$ & $0.5642-0.5659$ & $0.5611-0.5638$ & $0.5642-0.5654$ \\
\hline Inside & $0.5058-0.5064$ & $0.5060-0.5067$ & $0.5064-0.5068$ & $0.5051-0.5056$ \\
\hline \multicolumn{5}{|l|}{ Pellet Diameter, in } \\
\hline Oulside & \multicolumn{4}{|c|}{$\underline{0.500-0.501 \text { (Centerless Ground) }}$} \\
\hline Inside & Solid & Solid & Solid & Solid \\
\hline Average Pèllet Height, in & 0.519 & 0.519 & 0.519 & 0.519 \\
\hline Fuel Column Length, in & $333 / 4$ & $345 / 16$ & $341 / 4$ & $343 / 16$ \\
\hline Fuel Weight, Grams & 1141.2 & 1147.8 & 1157.0 & 1158.2 \\
\hline Plenum Length, in & $33 / 8$ & $211 / 16$ & $213 / 16$ & $27 / 8$ \\
\hline \multicolumn{5}{|l|}{ Heat Flux, Btu $/ \mathrm{h}-\mathrm{ft}^{2}$ : } \\
\hline \multicolumn{5}{|l|}{ Peak During } \\
\hline Irradiation & 630,000 & 665,000 & 675,000 & 732,000 \\
\hline \multirow[t]{2}{*}{ Peak at Shut-Down } & 515,000 & 545,000 & 550,000 & 600,000 \\
\hline & \multicolumn{4}{|c|}{ Fission Gas Released Based on Atoms of $\mathrm{Kr}^{85}$} \\
\hline \multicolumn{5}{|l|}{ Atoms Produced, Based } \\
\hline On Calorimetry $\times 10^{-19}$ & 0.906 & 0.963 & 0.973 & 1.058 \\
\hline \multicolumn{5}{|l|}{ Atoms Released $\times 10^{19}$ Based on: } \\
\hline Spectrometry & 10.5 & 30.0 & 29.9 & $\ldots$ \\
\hline ras-Chromatography & 11.3 & 25.6 & 29.0 & $\underline{-}$ \\
\hline \multicolumn{5}{|l|}{ Release Percents: } \\
\hline Spectrometry & 11.5 & 31.2 & 30.7 & 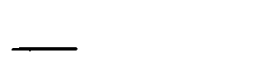 \\
\hline \multirow[t]{2}{*}{ Gas-Chromatogr aphy } & 12.5 & 26.5 & 29.8 & \\
\hline & \multicolumn{4}{|c|}{$\mathrm{UO}_{2}$ Volume Expansion Analysis Results } \\
\hline \multicolumn{5}{|l|}{ Calculated Volume, in ${ }^{3}$ : } \\
\hline Molten Zonc & 0.235 & 0.364 & 0.389 & 0.596 \\
\hline Zone Between 1600 and $2800^{\circ} \mathrm{C}$ & 1.125 & 1.191 & 1. 199 & 1.270 \\
\hline \multicolumn{5}{|l|}{ Free Volume Densification, in ${ }^{3}$ : } \\
\hline From Molten Zone & 0.012 & 0.018 & 0.0 .19 & 0.030 \\
\hline From 1600 to $2800^{\circ} \mathrm{C}$ & 0.028 & 0.030 & 0.030 & 0.032 \\
\hline Pellet Clad Gap Volume, in ${ }^{3}$ & 0.103 & 0.113 & 0.118 & 0.0087 \\
\hline Total Available Free Volume, in ${ }^{3}$ & 0.143 & 0.161 & 0.167 & 0.162 \\
\hline \multicolumn{5}{|l|}{ Calculated $\mathrm{UO}_{2}$ Thermal } \\
\hline Expansion, in ${ }^{3}$ & 0.148 & 0.172 & 0.176 & 0.210 \\
\hline \multicolumn{5}{|l|}{ Fuel Rod Volume increase, in ${ }^{3}$} \\
\hline a) Calculated Net & 0.007 & 0.011 & 0.009 & 0.048 \\
\hline b) Experimental & 0.0099 & 0.0320 & 0.1320 & 0.0911 \\
\hline
\end{tabular}




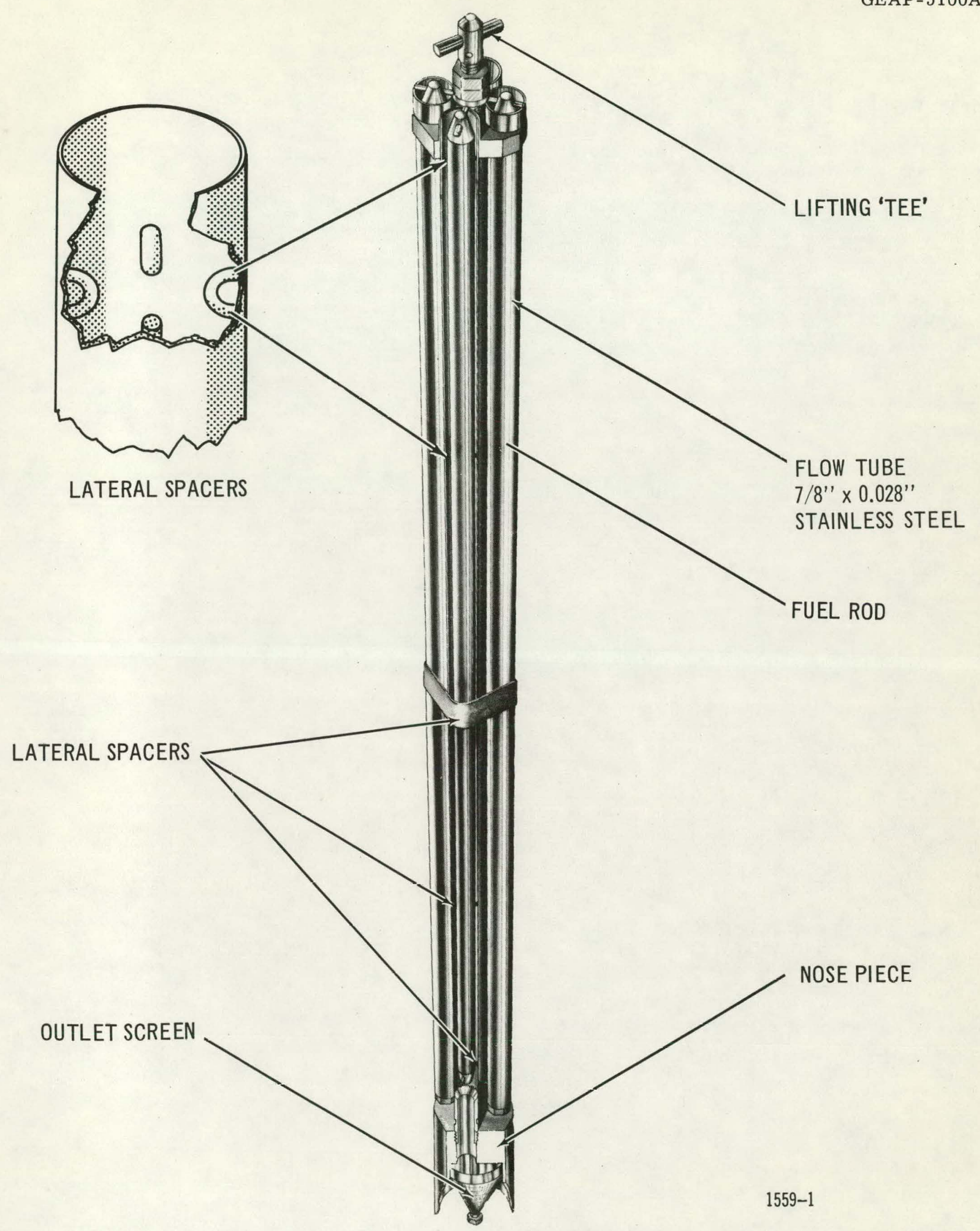

Figure 3. Fuel Assembly Design 
TOP OR INLET END SHOWING LIFTING TEE

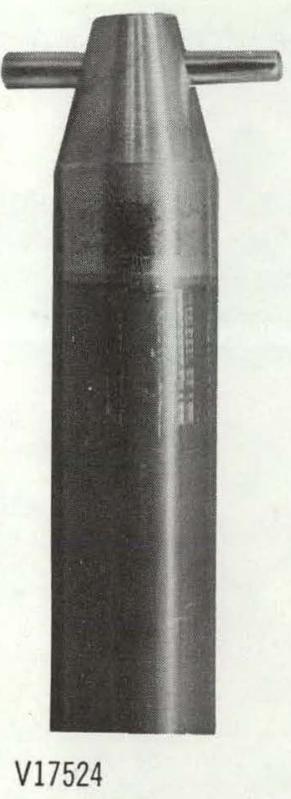

FUEL ELEMENT TOP END PLUG AND LOCKING PIN
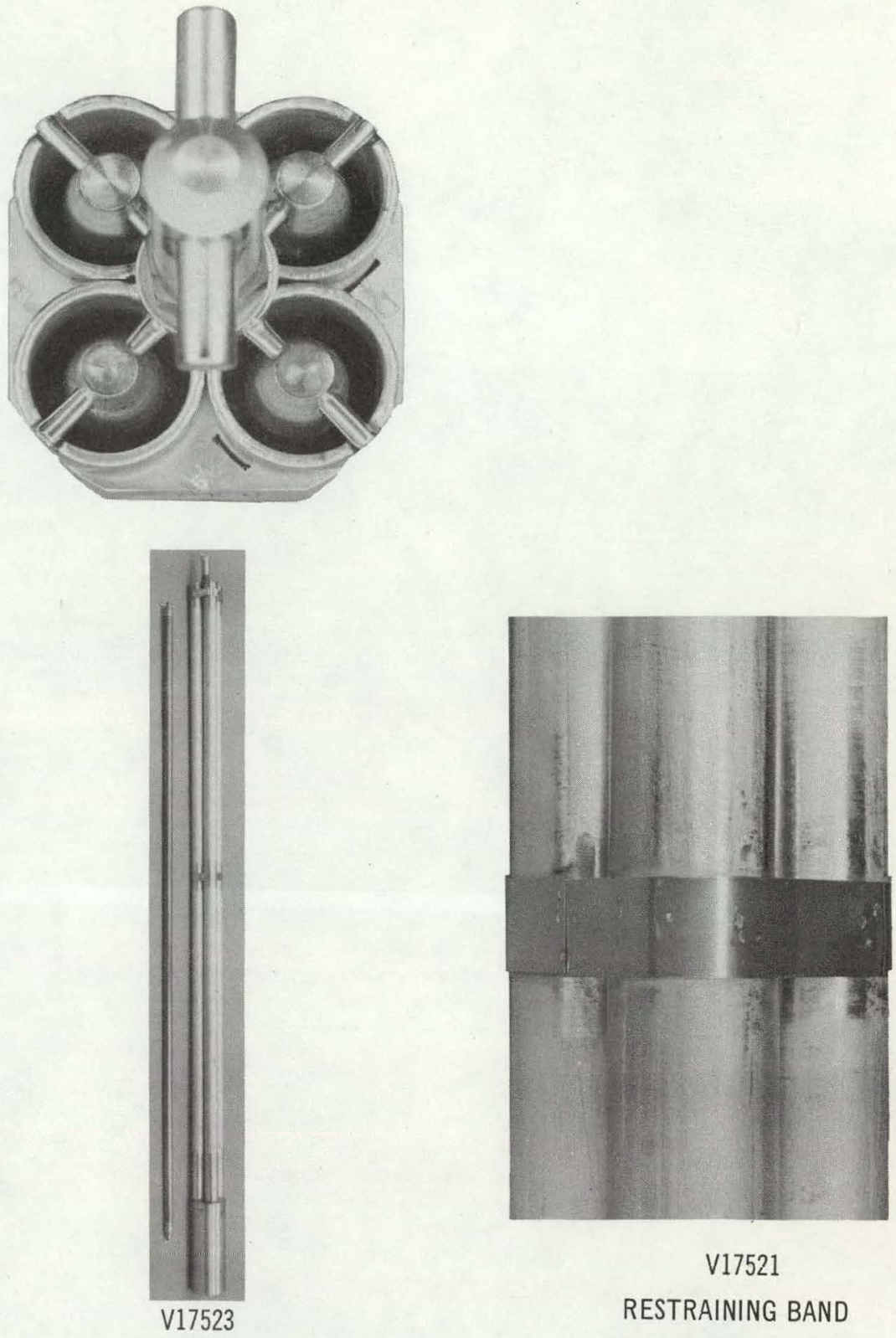

V17521

RESTRAINING BAND AROUND FLOW TUBES

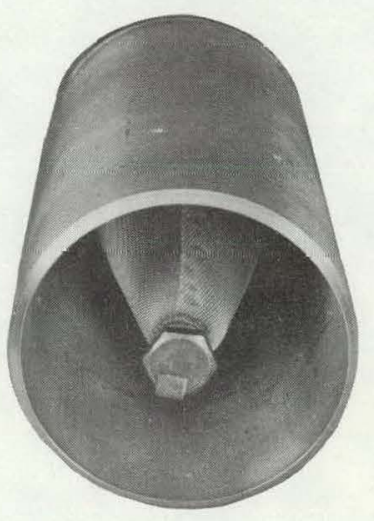

V17522

NOSE PIECE WITH SCREEN

AT THE BOTTOM OR EXIT END

Figure 4. Pre-Irradiation Appearance 


\begin{tabular}{|c|l|}
\hline 1 & END PLUG \\
2 & DISK \\
3 & PIN \\
4 & SPRING \\
5 & TUBE \\
6 & PELLET \\
7 & END PLUG \\
8 & PIN \\
\hline
\end{tabular}

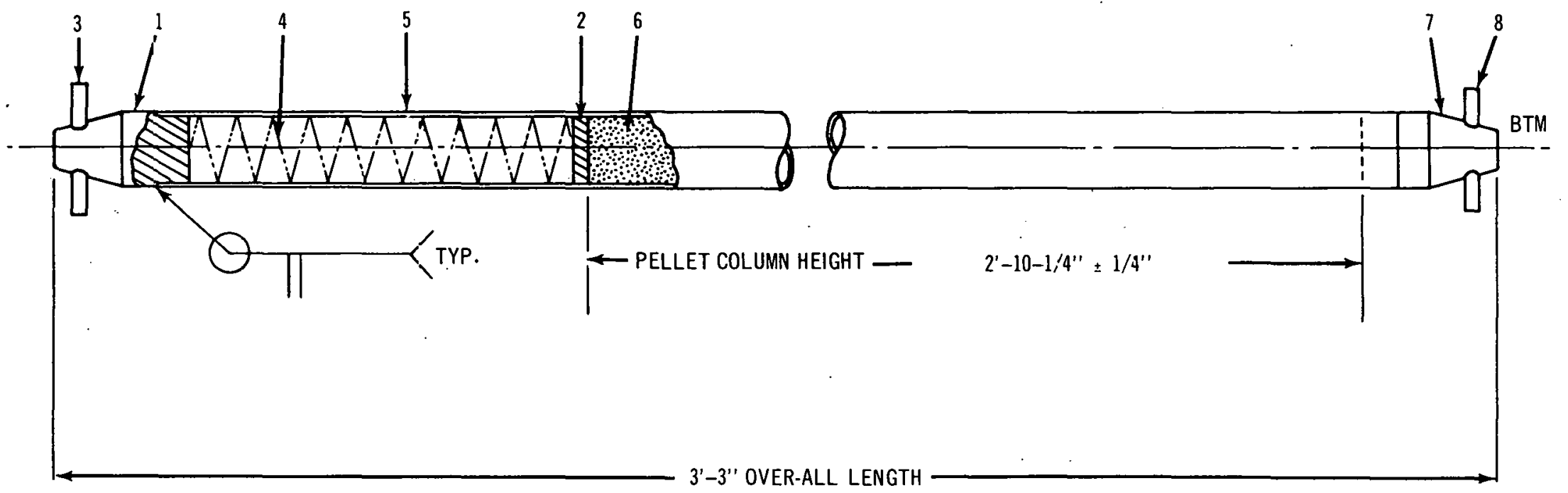




\section{GAMMA SCAN RESULTS}

Based on previous experience with gamma scans from fuel rods without central melting, a normal gamma activity profile is a smooth, regular curve with a shape approximating the average thermal neutron flux profile during irradiation. Rods containing $\mathrm{UO}_{2}$ pellets usually exhibit slight depressions in the profile at the pellet interfaces and one of the main values of gamma scan has been to locate the individual pellets and, thereby, show the general, post-irradiation condition of the fuel column.

The gamma scan from rod 6D, is a normal profile in most respects. However, the scan indicates that definite pellet separation occured in the region of maximum clad swelling, 9 inches above the rod bottom. This separation was confirmed by sectioning and metallography. Axial separation of the pellets has not been observed in any other rod examined during the program and the reason for its occurance in rod $6 \mathrm{D}$ is unexplained. It cannot be attributed to clad swelling alone since subsequent rods exhibited greater clad swelling without axial separation.

The most unusual feature of the rod 6D gamma scan is the sharp activity spike near the axial midpoint of the rod. This type of spike had not been observed before and it is believed to be an indication of a concentration of fission products in the hottest zone of the rod; probably a concentration within the $\mathrm{UO}_{2}$ that was molten just before shutdown. When coupled with the autoradiograph results there is little doubt that the axial relocation and concentration of fission product activity actually occurs. *

\footnotetext{
*See GEAP-4264 Section IX-E.
} 


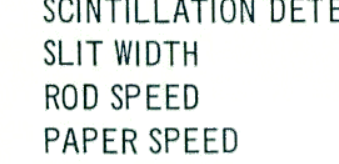

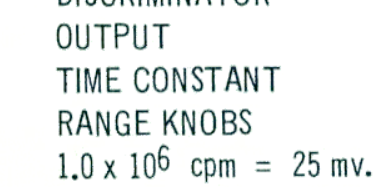

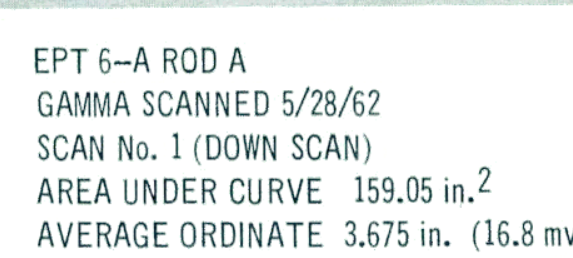

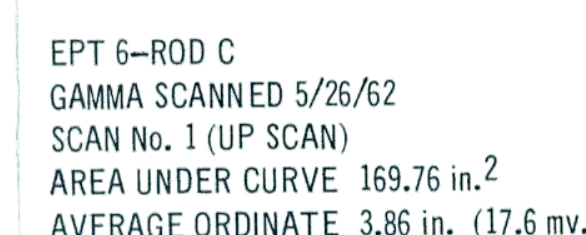

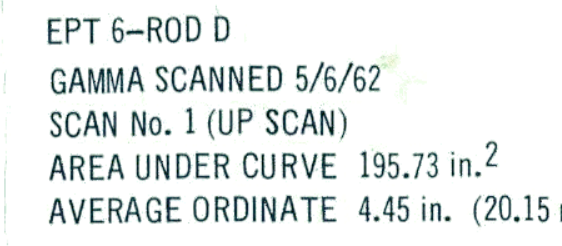




\section{EPT-6 ROD-A}

FRACTURE SECTIONS 
ROD ELEVATION 1 Inch

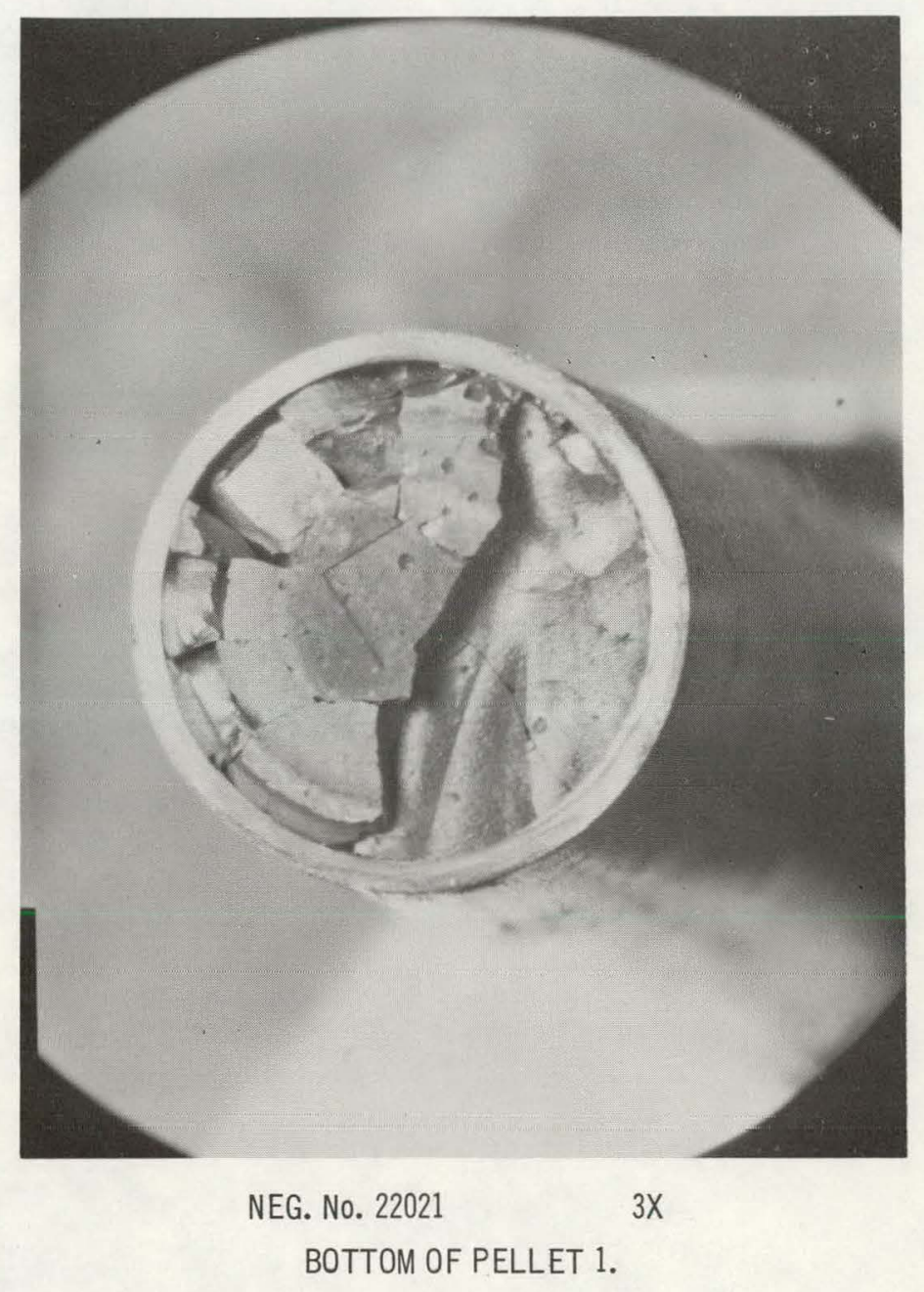




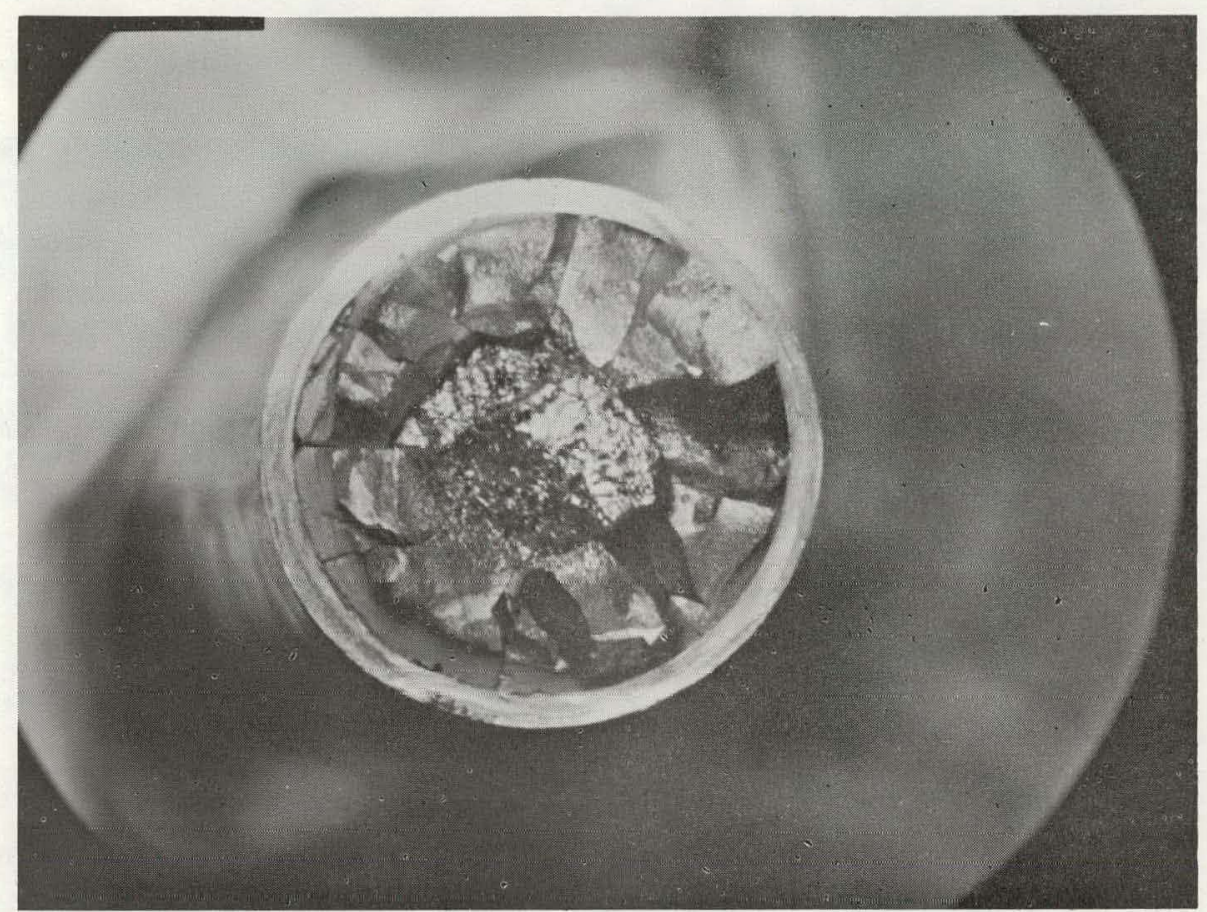

NEG. No. 22023

$3 x$

BOTTOM OF PELLET 9.

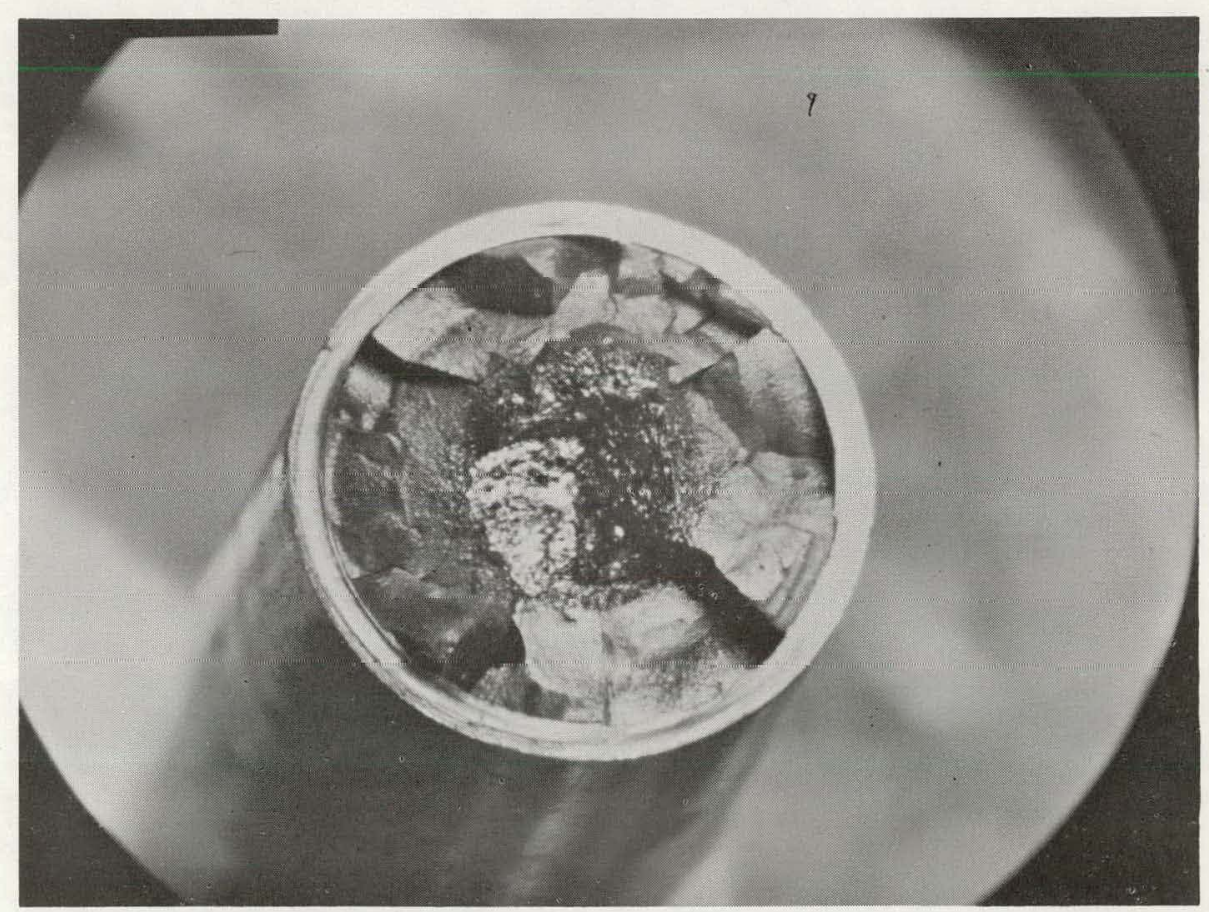

NEG. No. 22022

$3 X$

TOP OF PELLET 8. 


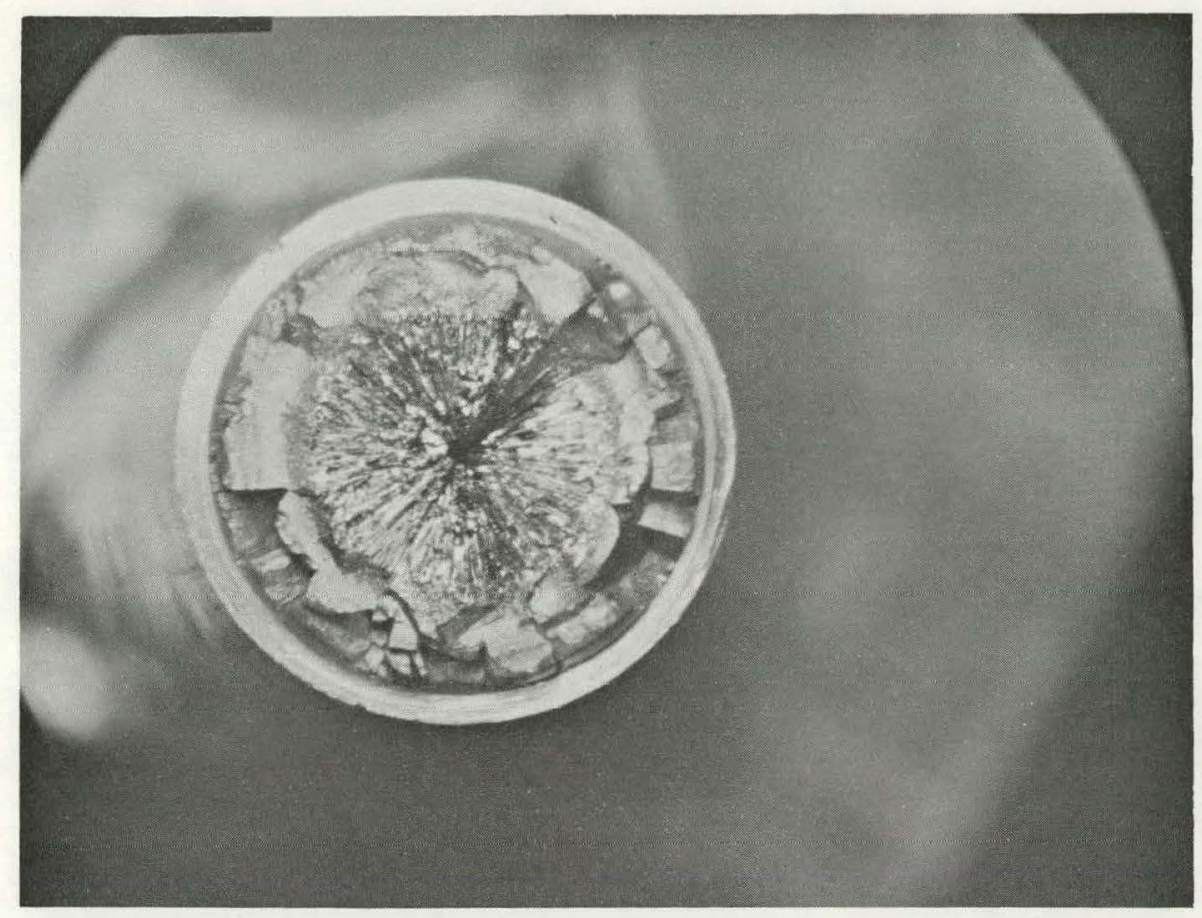

NEG. No. 22026

$3 x$

BOTTOM OF PELLET 17

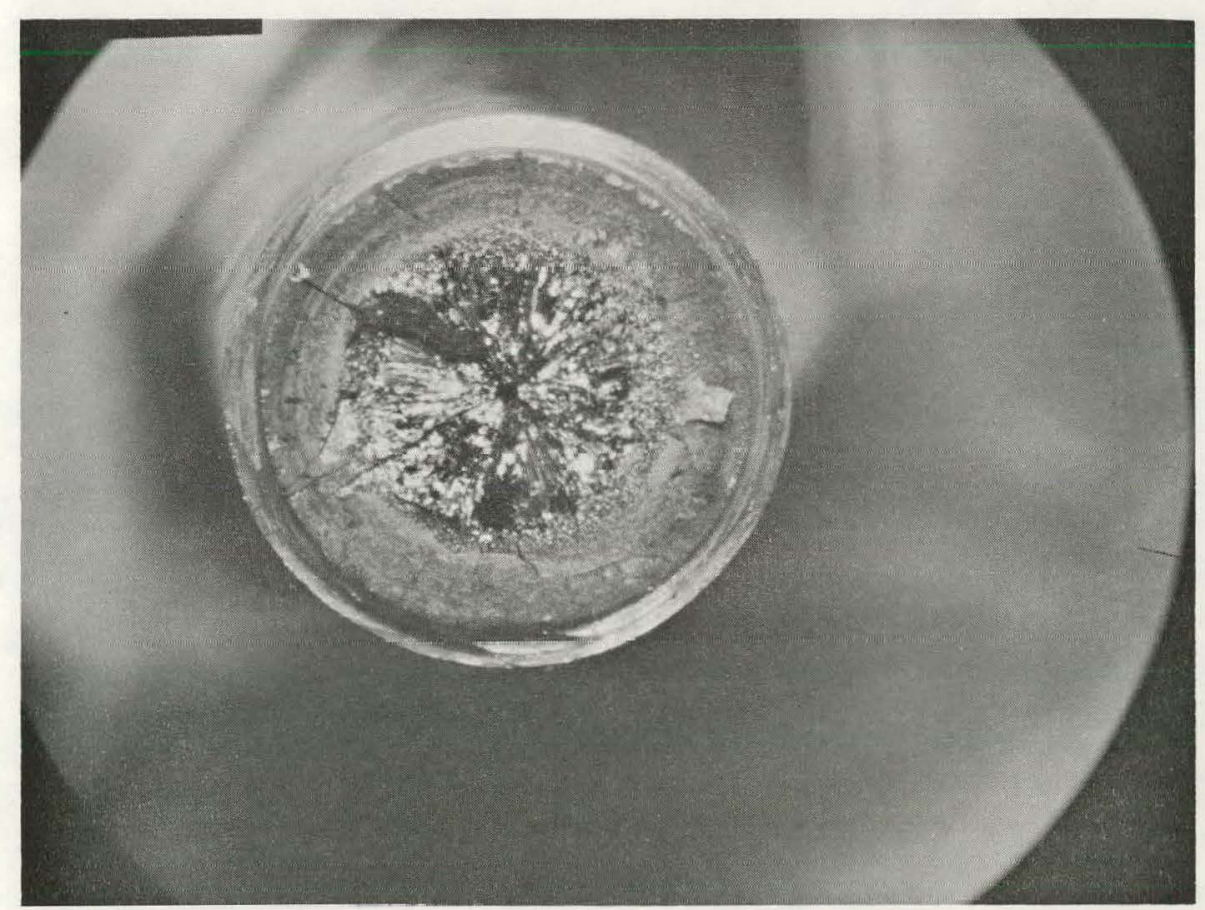

NEG. No. 22024

$3 x$

TOP OF PELLET 16. 
ROD ELEVATION $133 / 8$ Inches

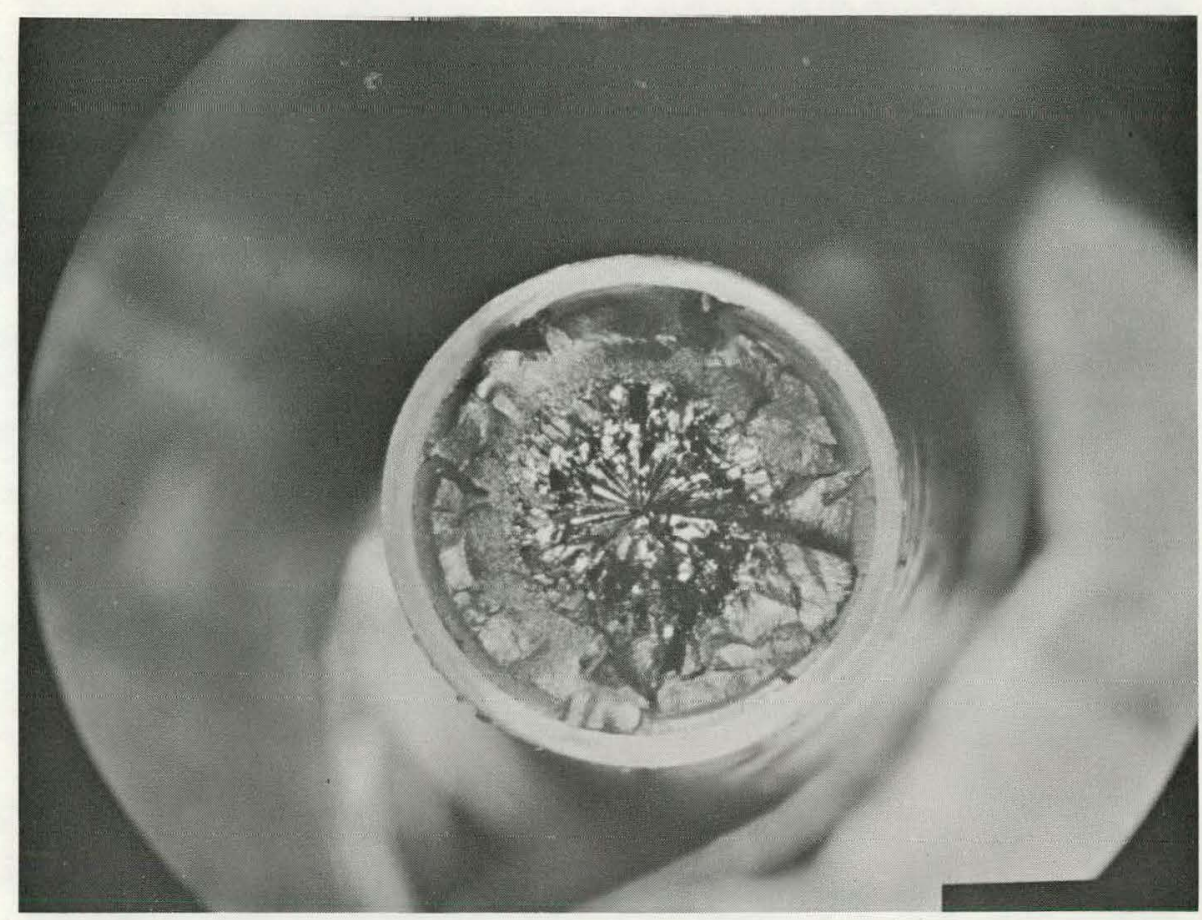

NEG. No. 22028

$3 x$

BOTTOM OF PELLET 25.

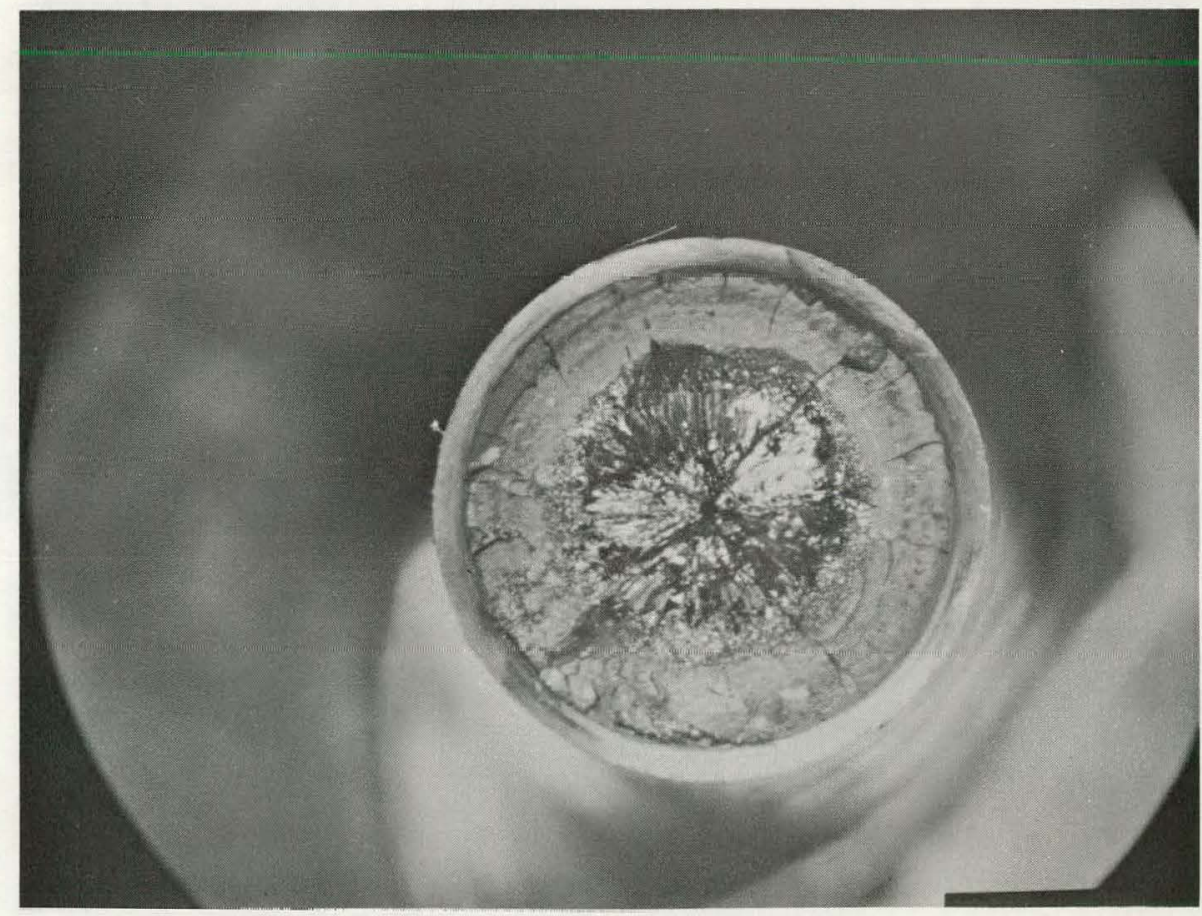

NEG. No. 22025

$3 x$

TOP OF PELLET 24. 
ROD ELEVATION 17 1/8 Inches

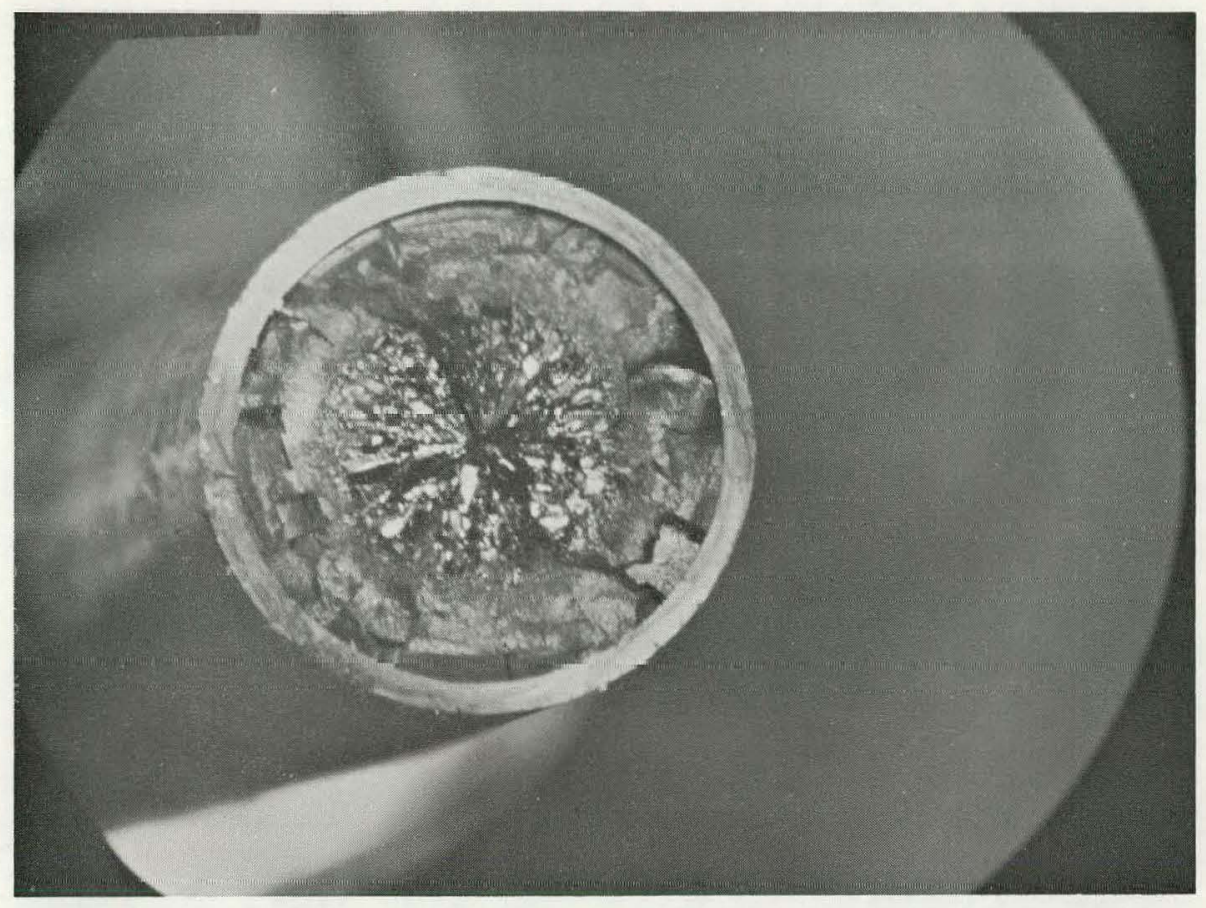

NEG. No. 22029

$3 X$

BOTTOM OF PELLET 32.

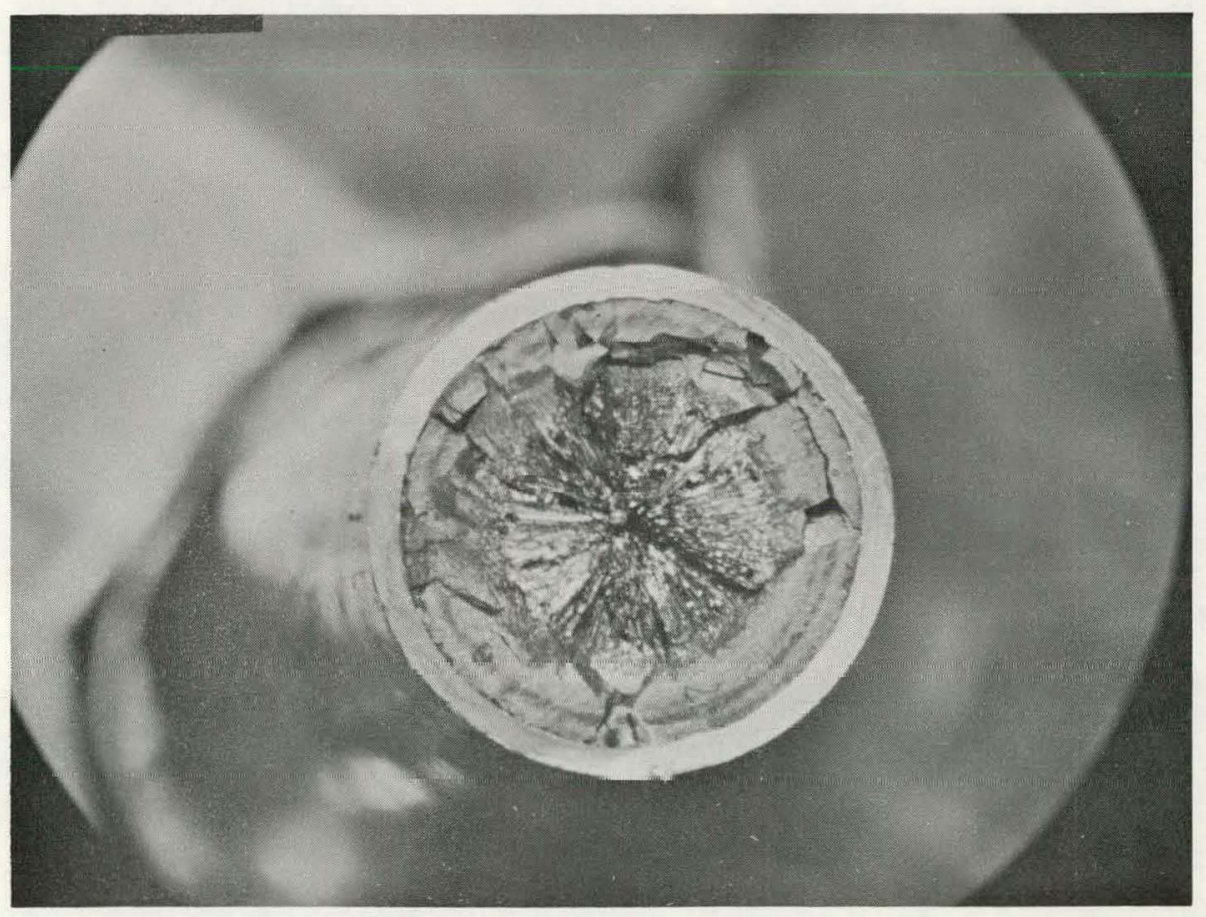

NEG. No. 22027

$3 x$

TOP OF PELLET 31. 
ROD ELEVATION 191/2 Inches

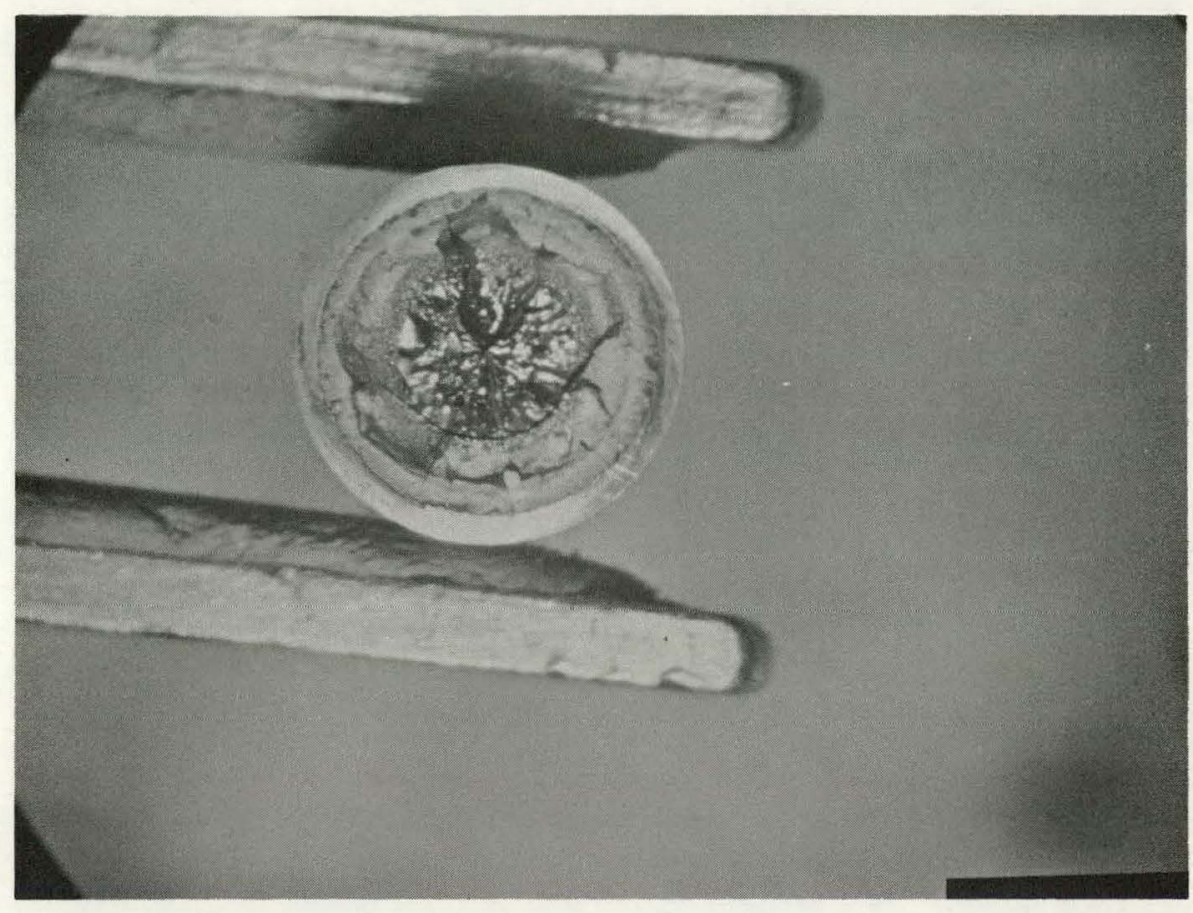

NEG. No. 26927

$3 X$

TOP OF PELLET 36.

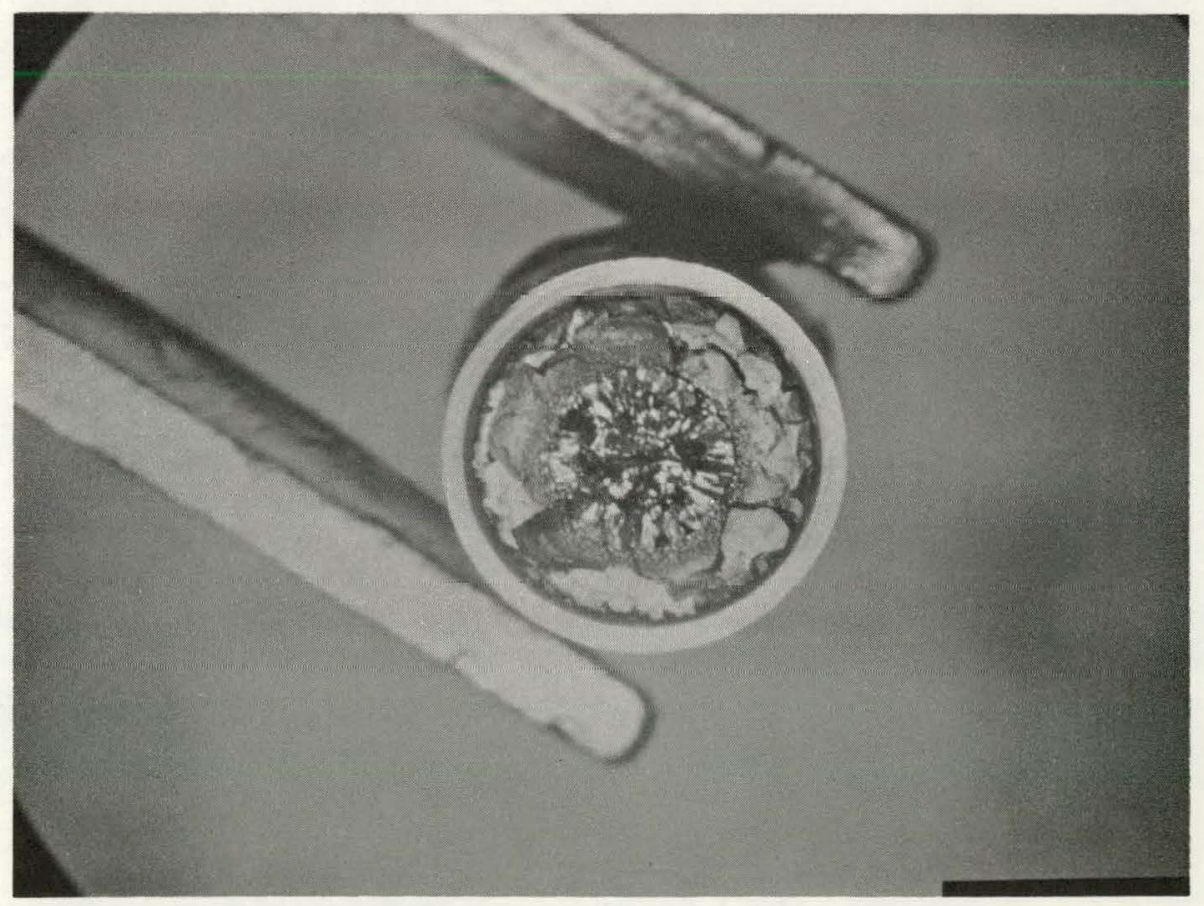

NEG. No. 26928

$3 x$

BOTTOM OF PELLET 36. 
ROD ELEVATION $213 / 8$ Inches

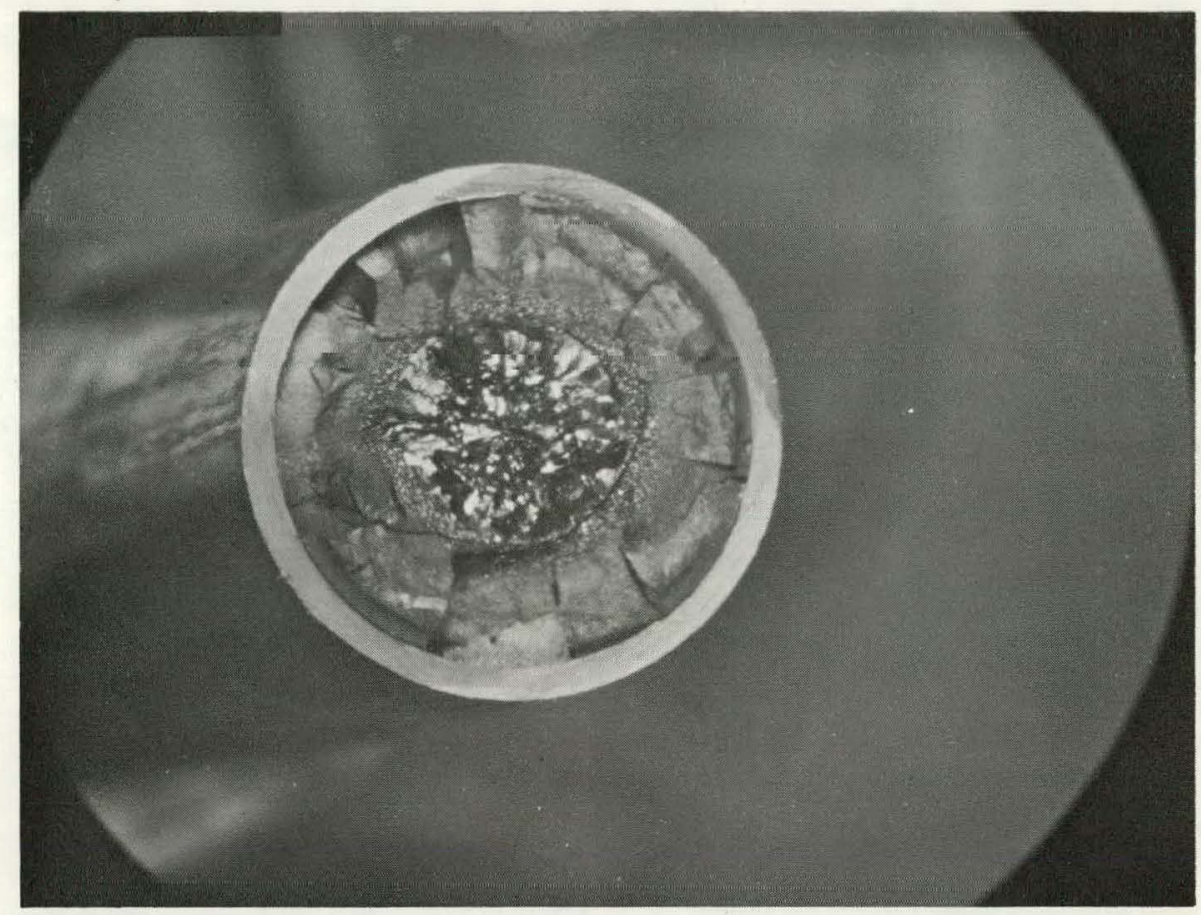

NEG. No. 22032

$3 x$

BOTTOM OF PELLET 41.

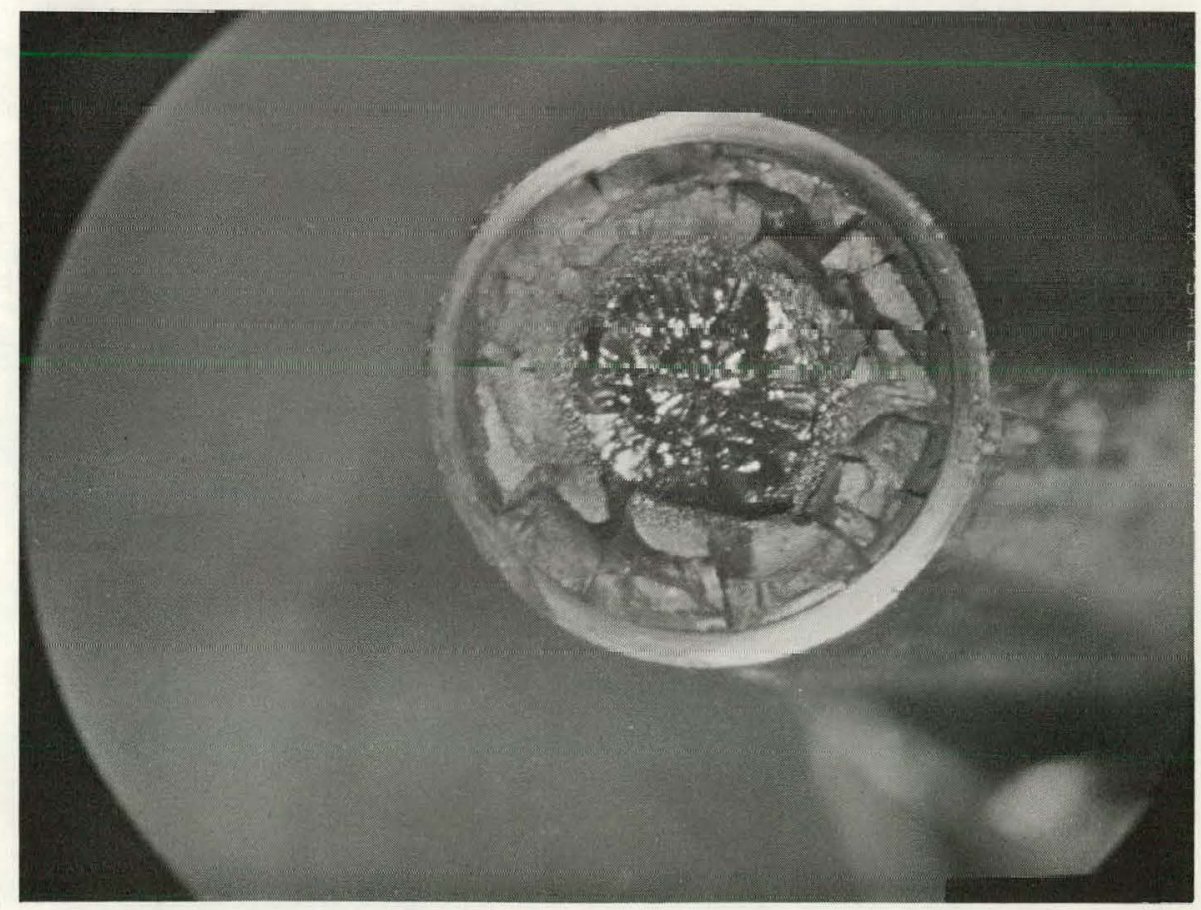

NEG. No. 22030

$3 x$

TOP OF PELLET 40. 


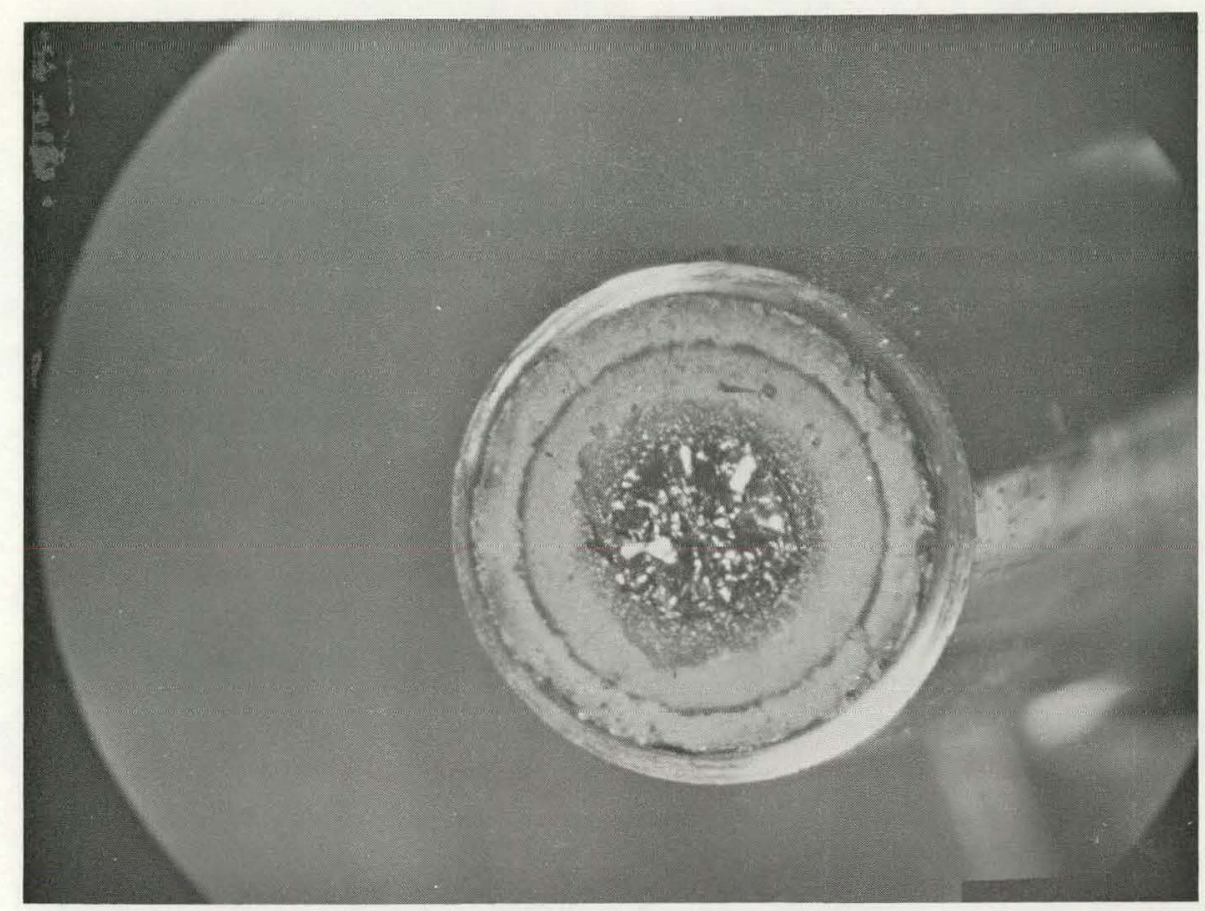

NEG. No. 22033

$3 x$

BOTTOM OF PELLET 49.

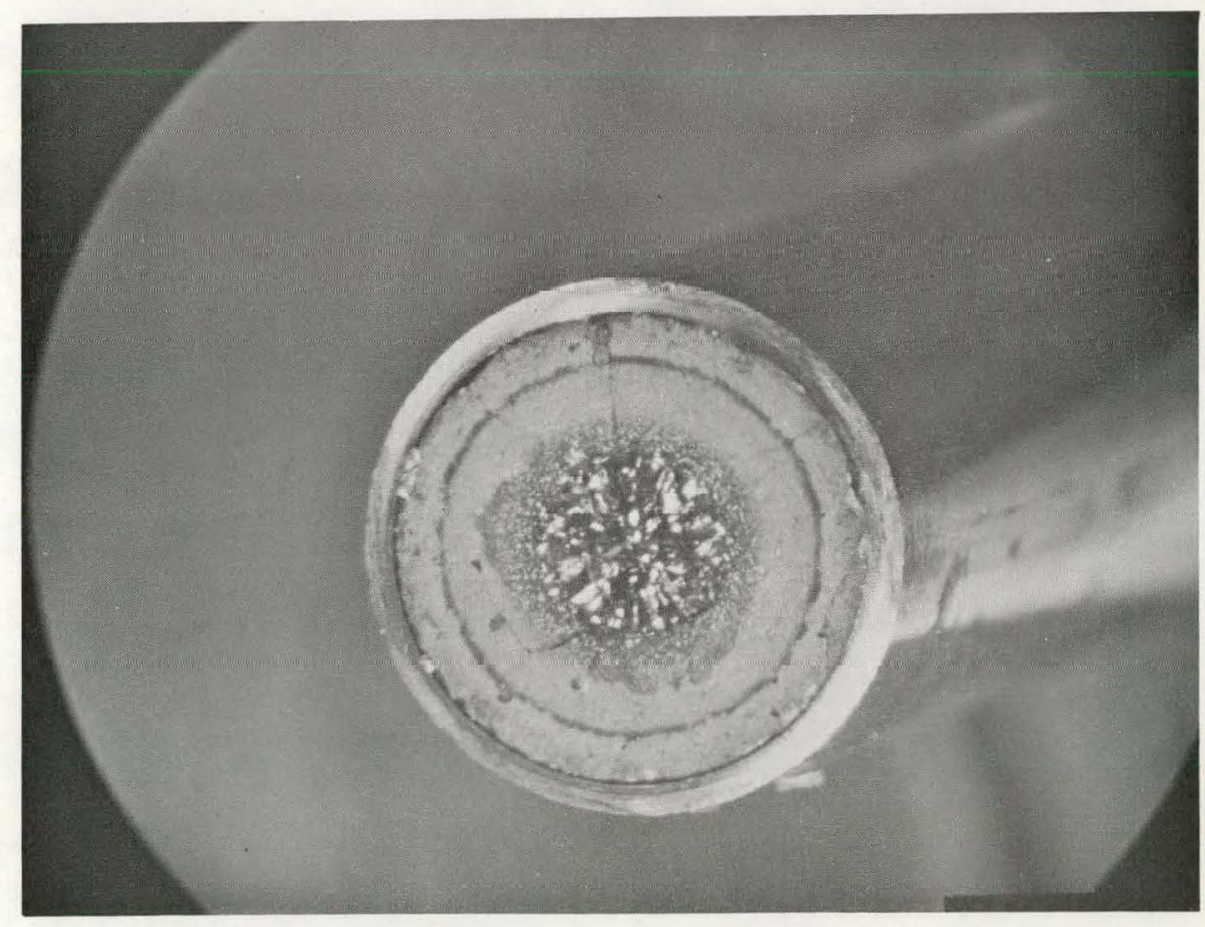

NEG. No. 22031

$3 x$

TOP OF PELLET 48. 


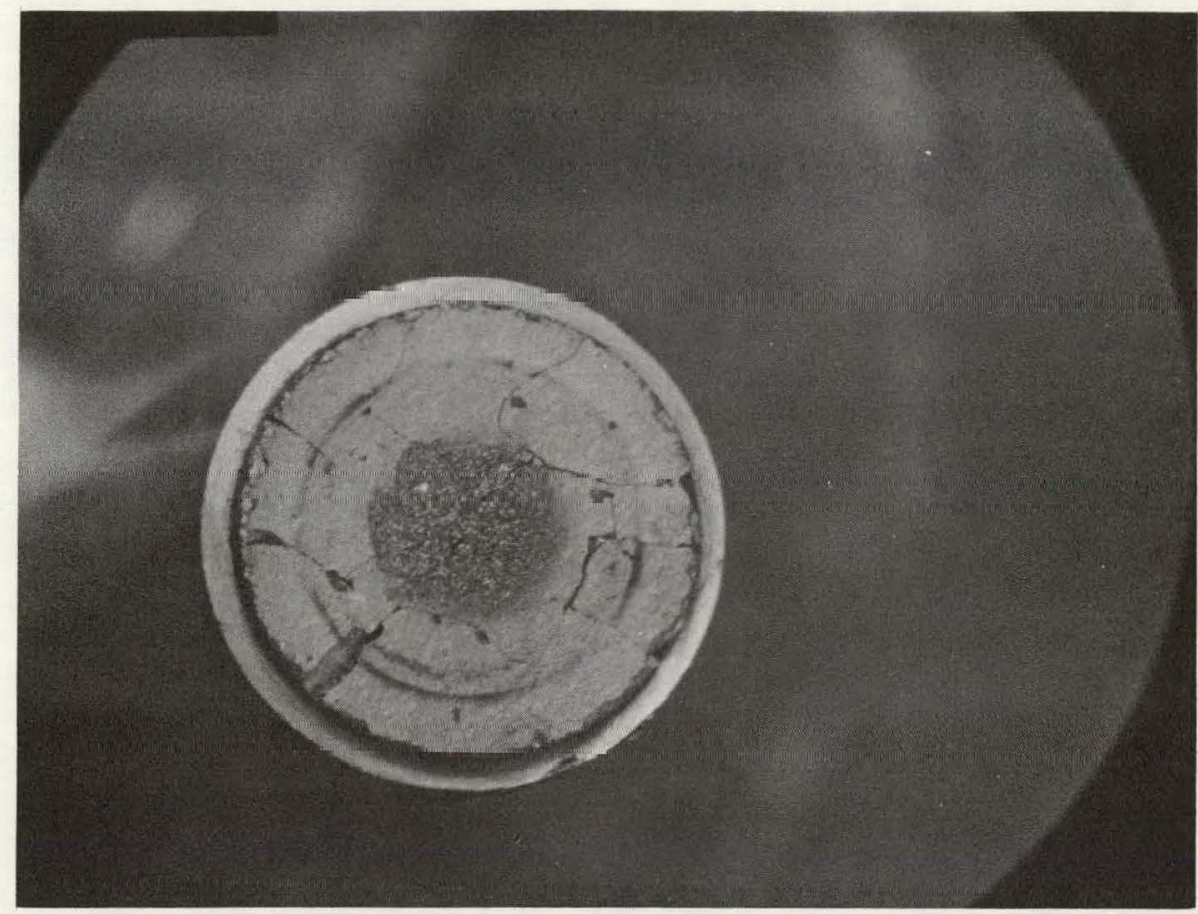

NEG. No. 22035

BOTTOM OF PELLET 57.

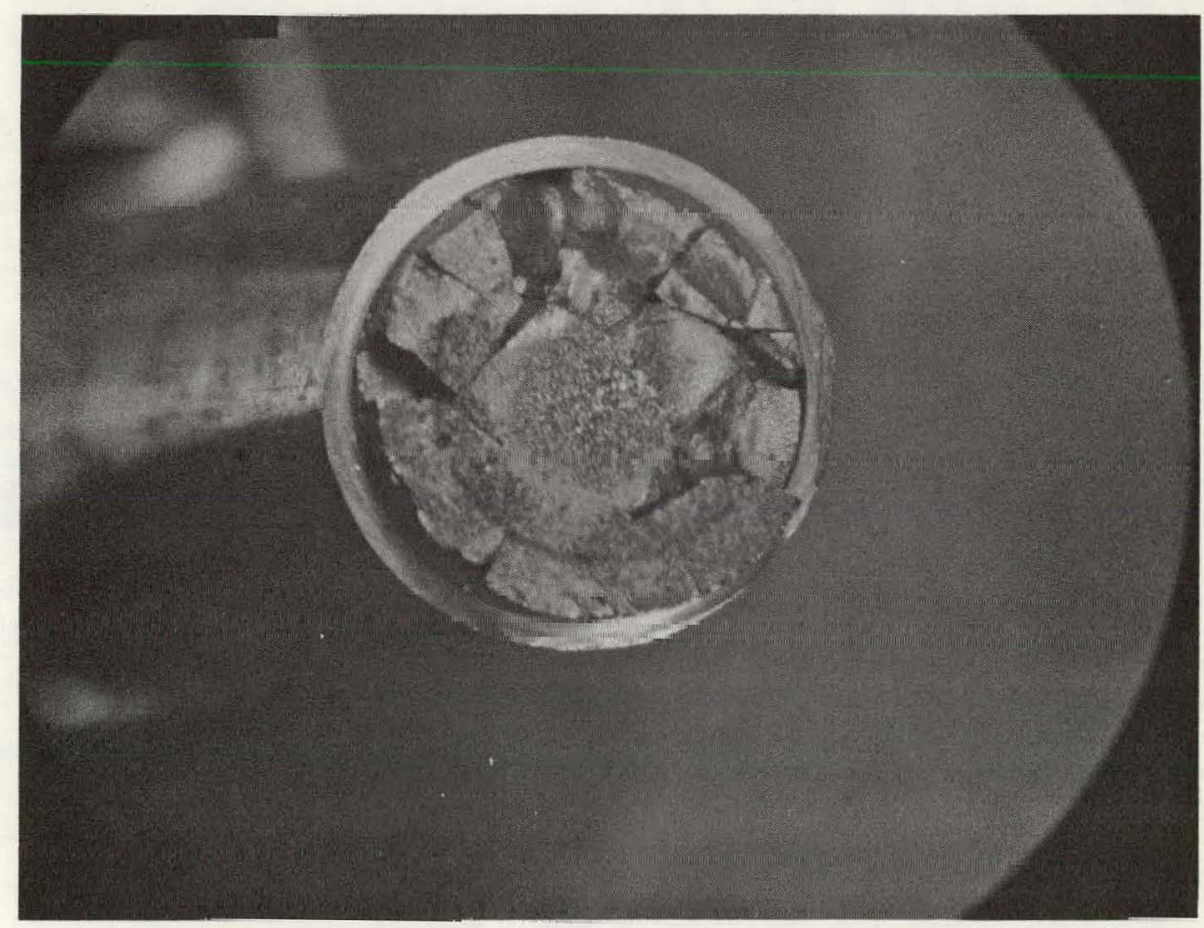

NEG. No. 22034

$3 x$

TOP OF PELLET 56. 
GEAP-5100A

ROD ELEVATION 33 3/8 Inches

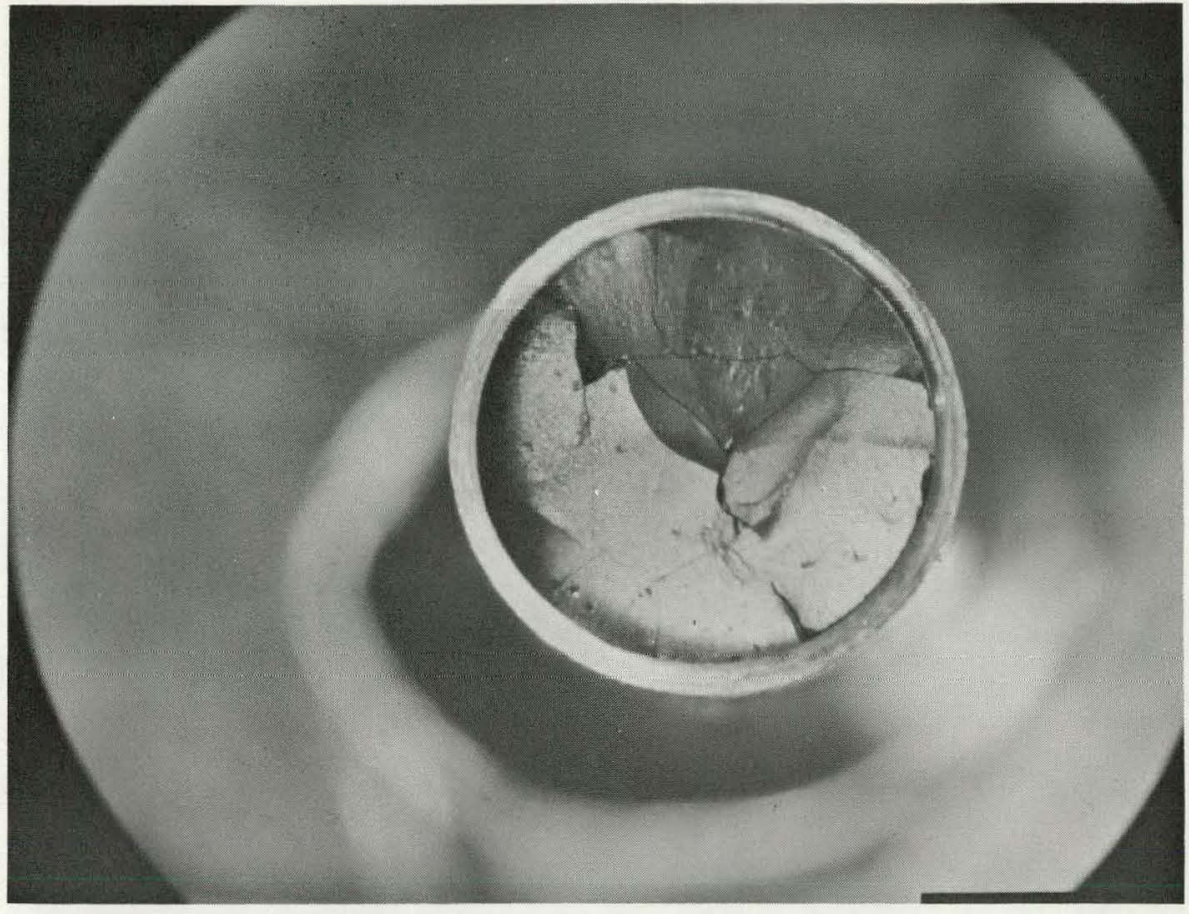

NEG. №. 22037

$3 X$

BOTTOM OF PELLET 63.

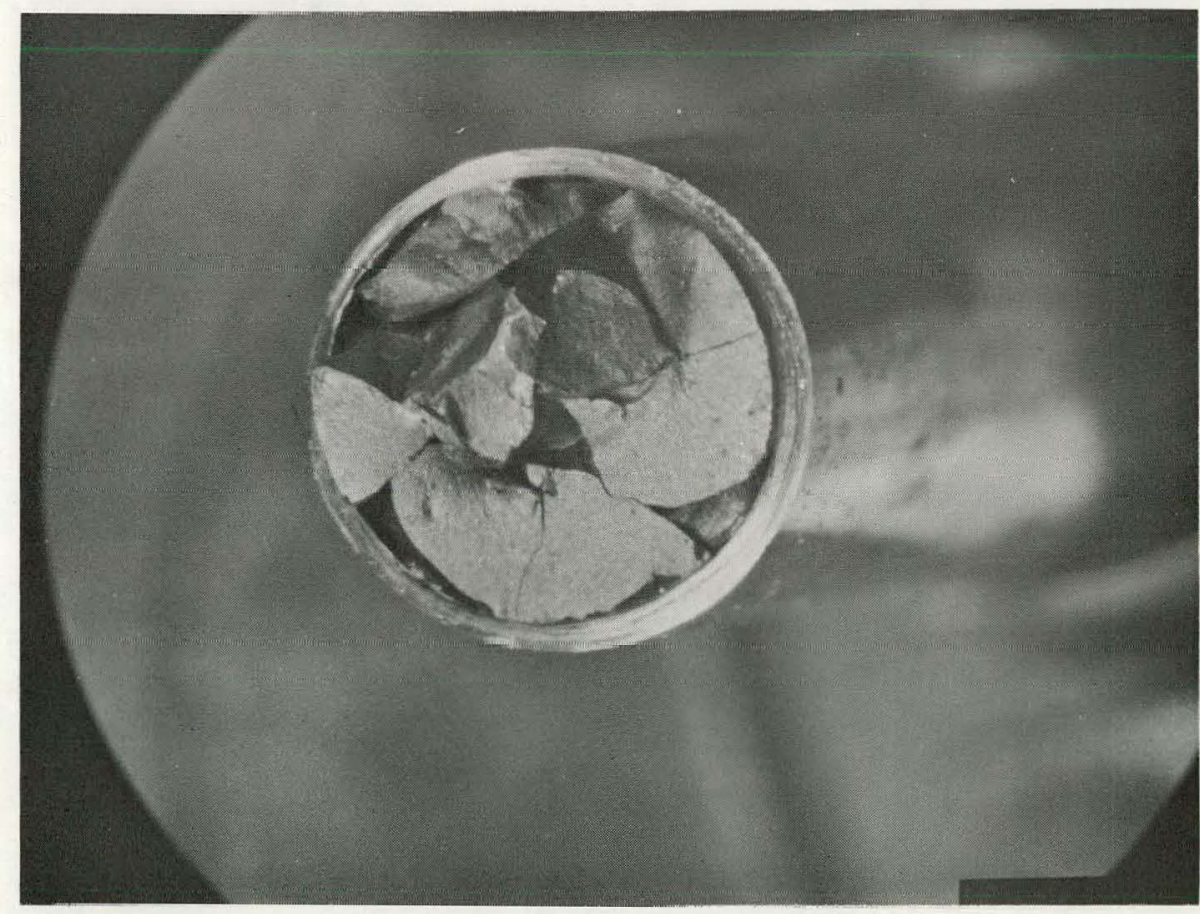

NEG. No. 22036

$3 X$

TOP OF PELLET 62. 


\section{EPT-6 ROD-A}

\section{METALLOGRAPHIC SECTIONS}

ALL SECTIONS ARE "AS POLISHED" UNLESS MARKED "ETCHED." ALL LIGHTING USED IS "BRIGHT FIELD" UNLESS MARKED "POLARIZED LIGHT."

NUMBERS AFTER AUTORADIOGRAPH CAPTIONS INDICATE NUMBER OF DAYS AFTER END OF IRRADIATION. 


\title{
EPT-6 ROD-A
}

\author{
PEAK HEAT FLUX ZONE
}

ROD ELEVATION 91/4 Inches FROM BOTTOM 
ROD ELEVATION 91/4 Inches

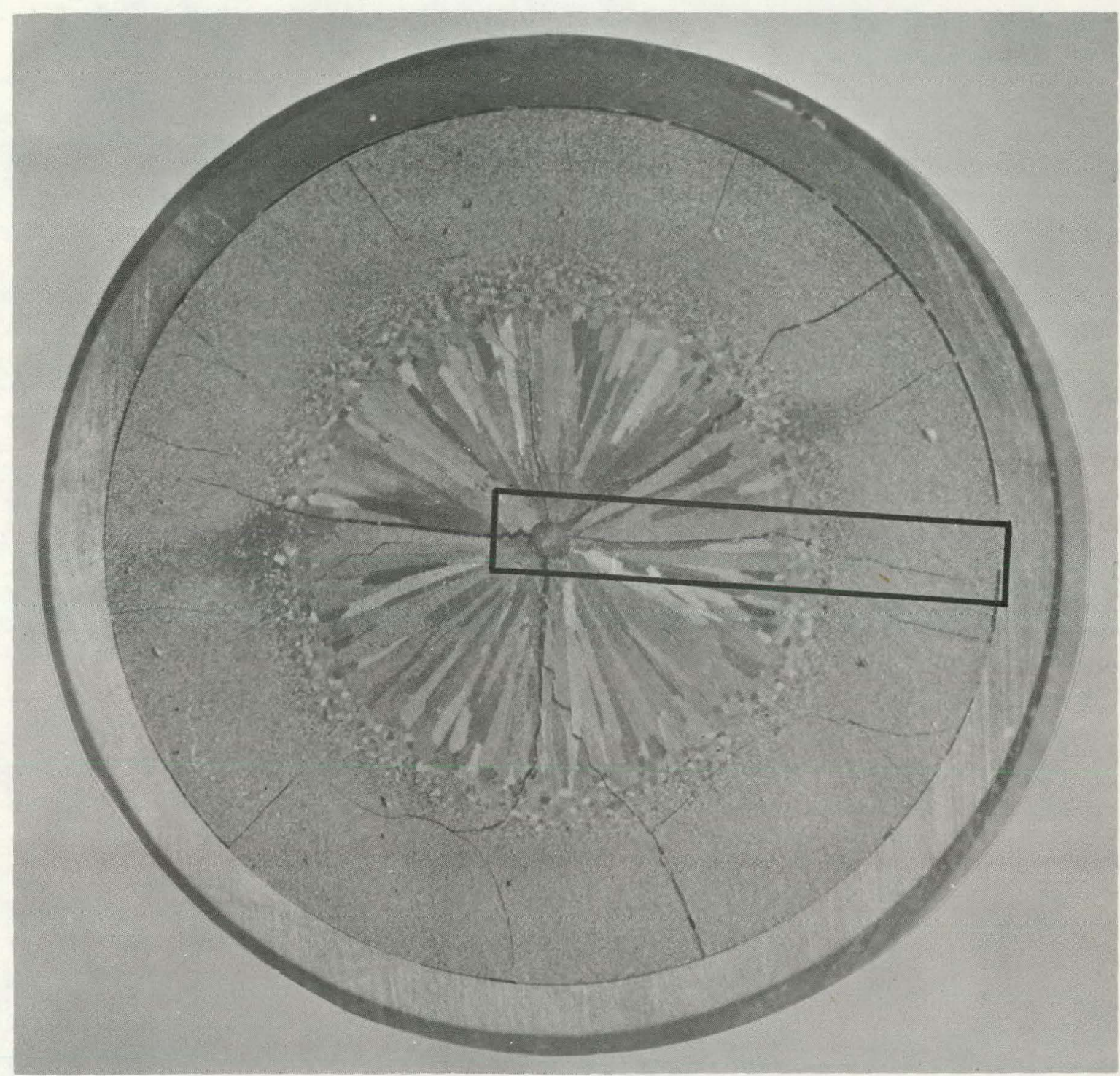

NEG. No. 8716-01 (OFF $600 \mathrm{SiC}$ ) $10 \mathrm{X}$

PHOTOMACROGRAPH OF TRANSVERSE FUEL ROD SECTION AT START-IIP PEAK HEAT FLUX ZONE BETWEEN PELLETS 16 \& 17. 
ROD ELEVATION 91/4 Inches

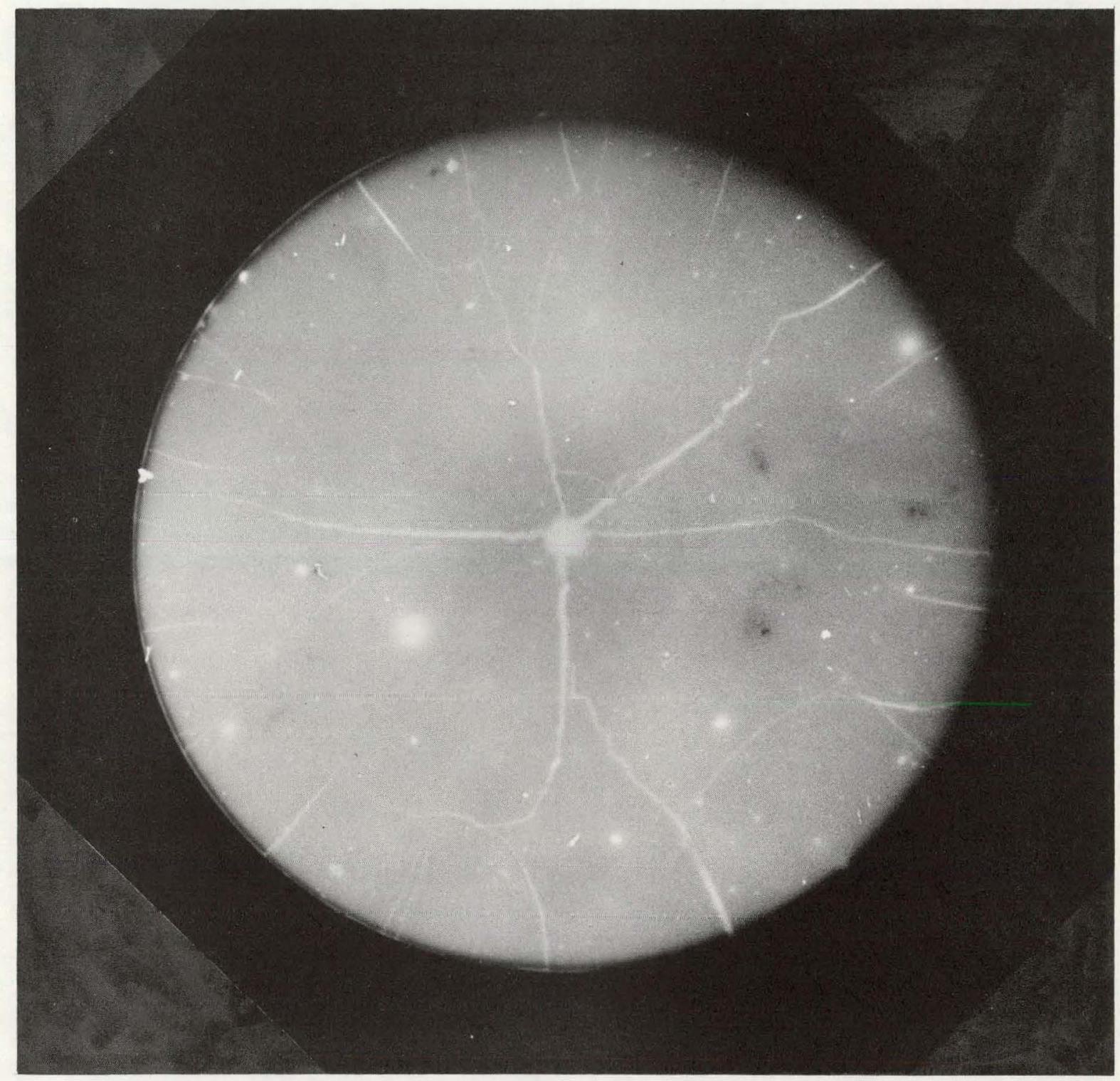

NEG. №. 8716-03 (AS POI ISHFD) $10 \mathrm{X}$ $\beta-\gamma$ AUTORADIOGRAPH OF SAME SECTION AS IN N.EG. 8716-01. 




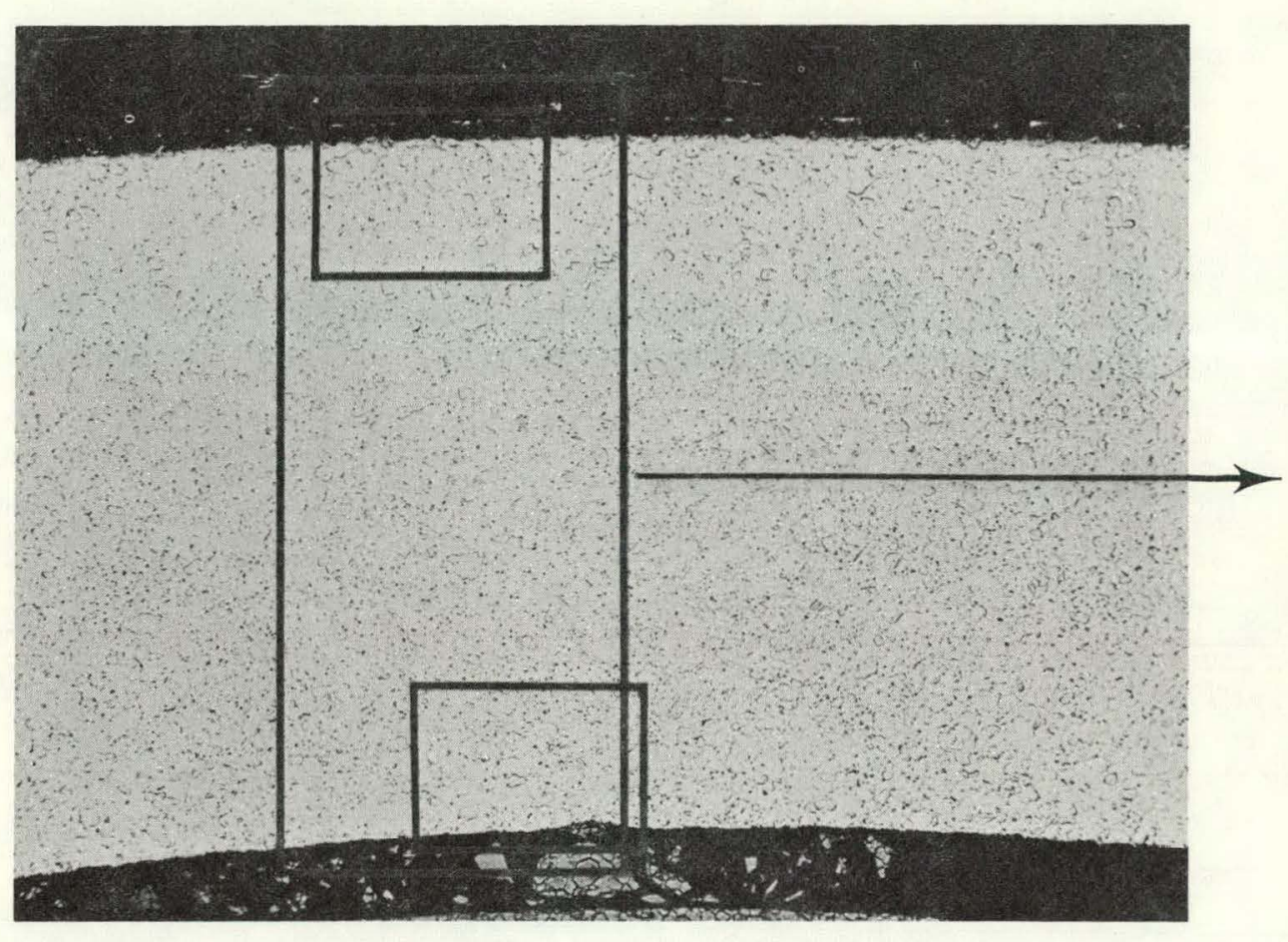

NEG. No. $8716-25$ $100 x$ REPRESENTATIVE CLADDING SECTION

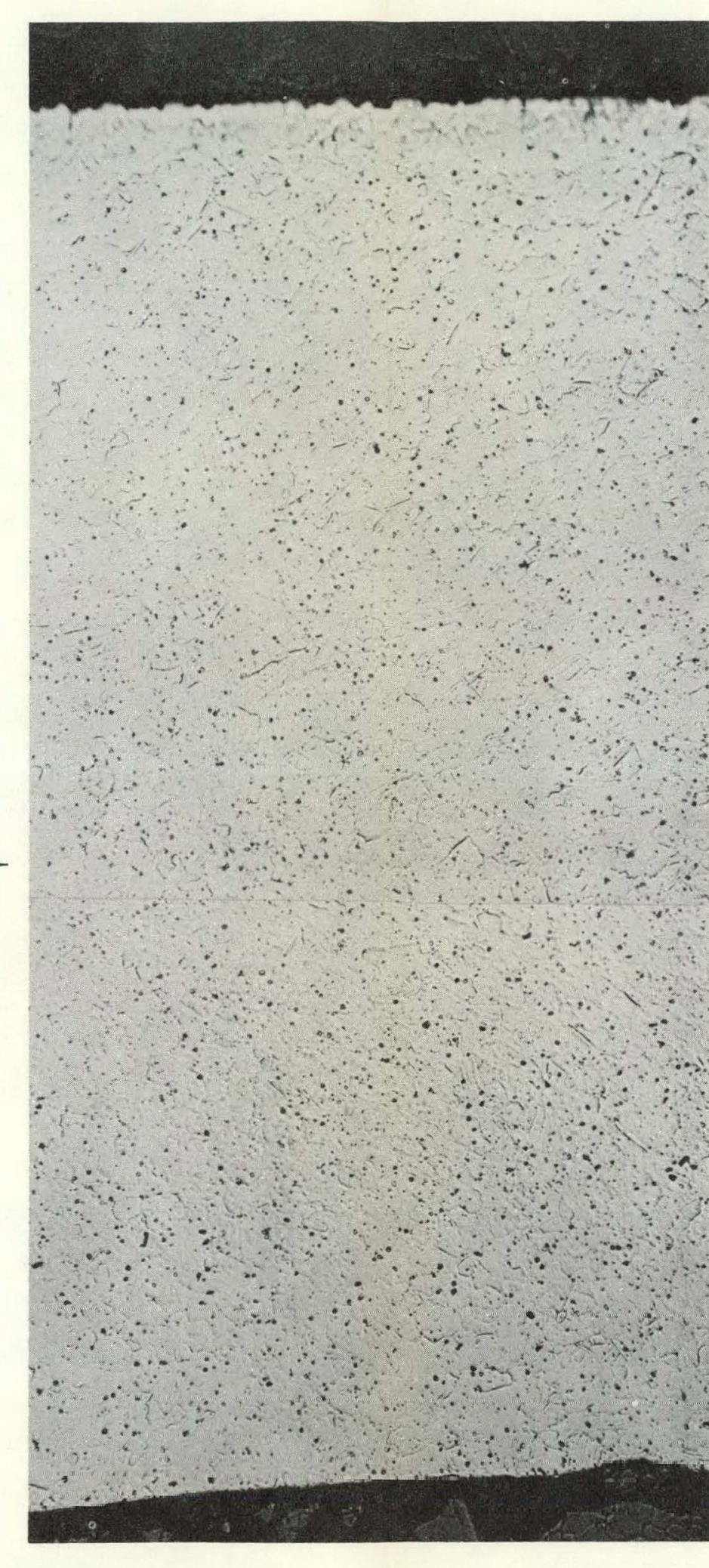

NEG. No. $8716-31 / 8716-32$

$250 \mathrm{X}$

COMPOSITE OF CLADDING SECTION

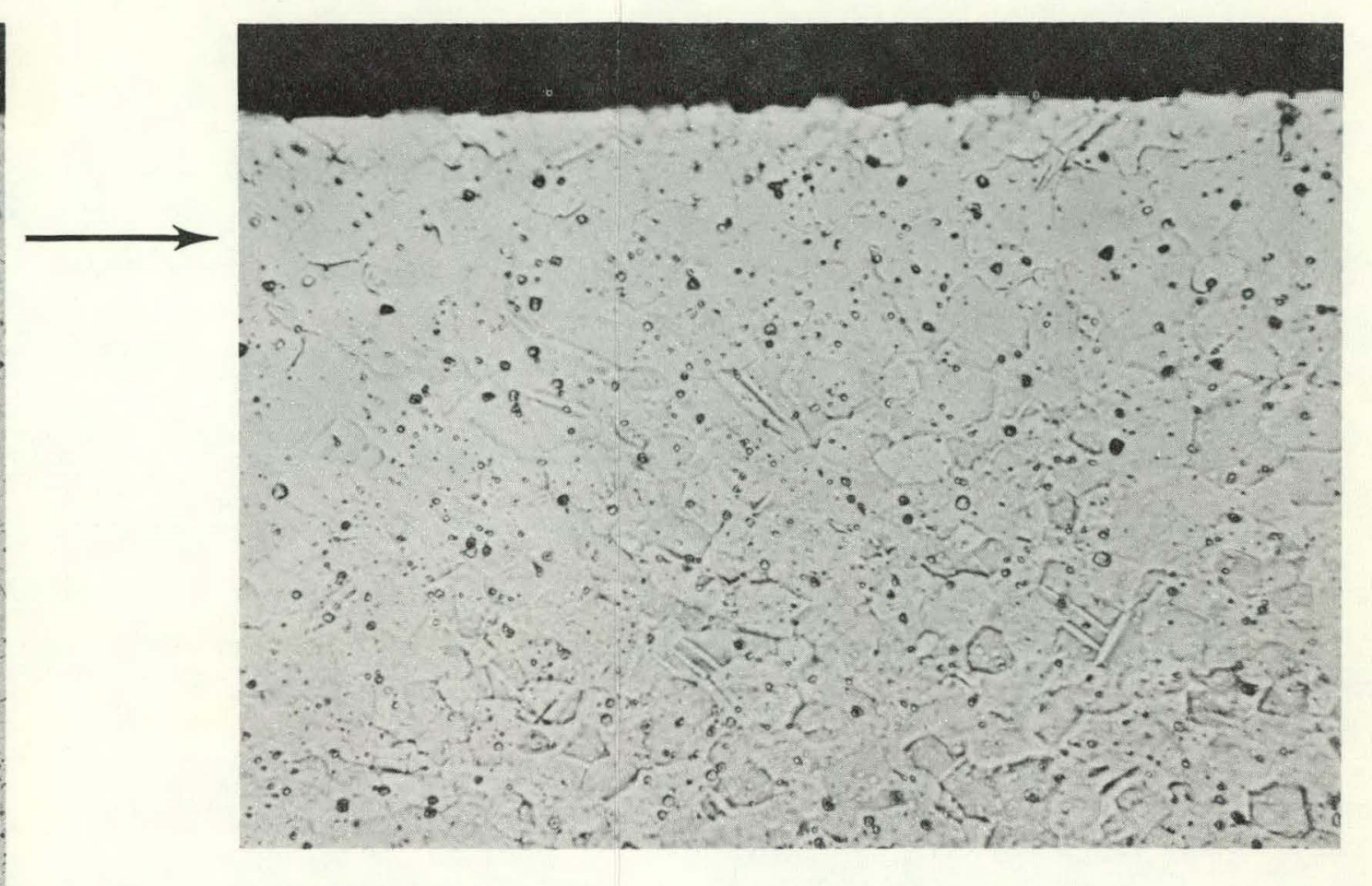

NEG. No. $8716-27$

CLADDING OUTSIDE DIAMETER

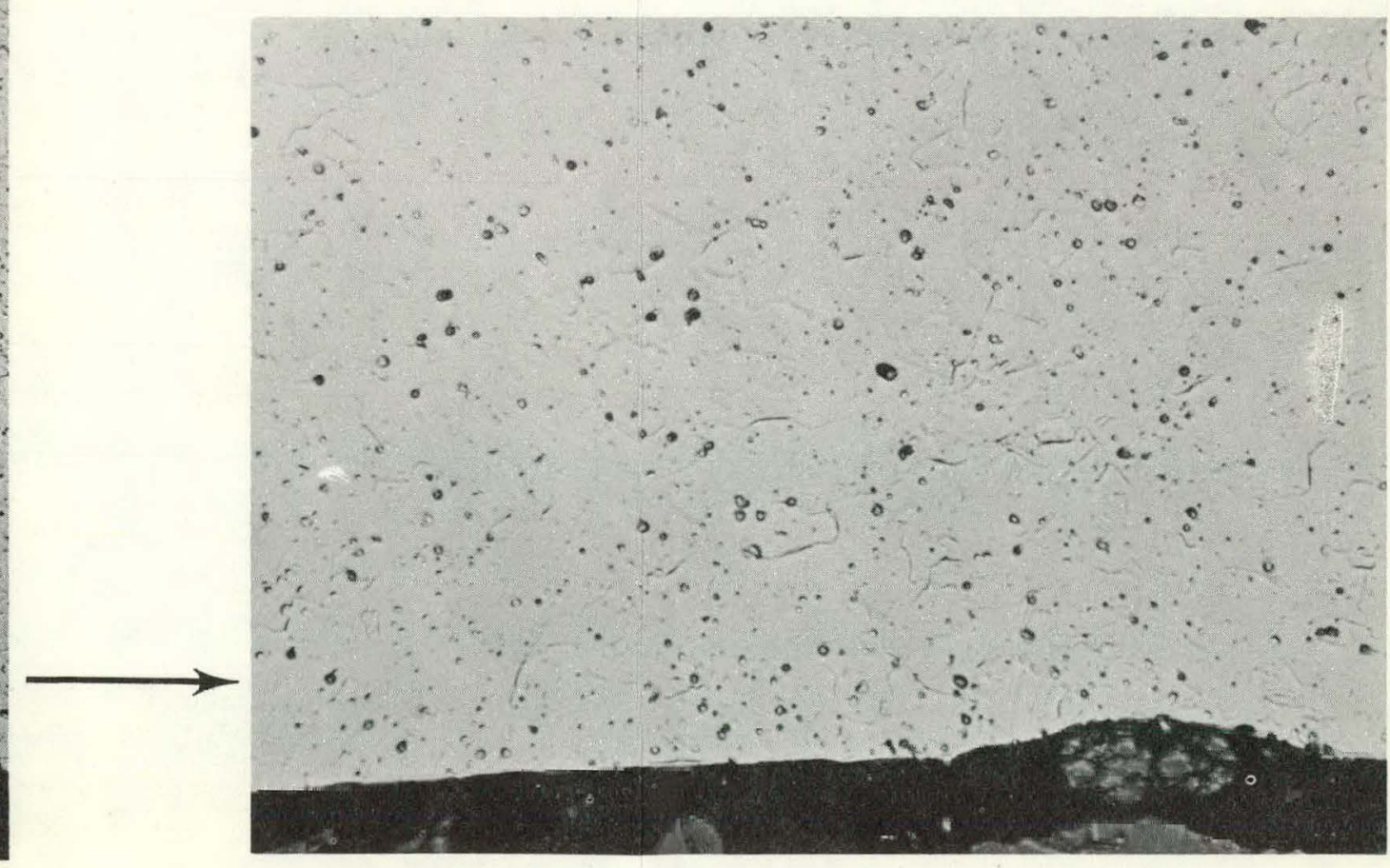

NEG. No. $8716-29$

$500 x$

CLADDING INSIDE DIAMETER 


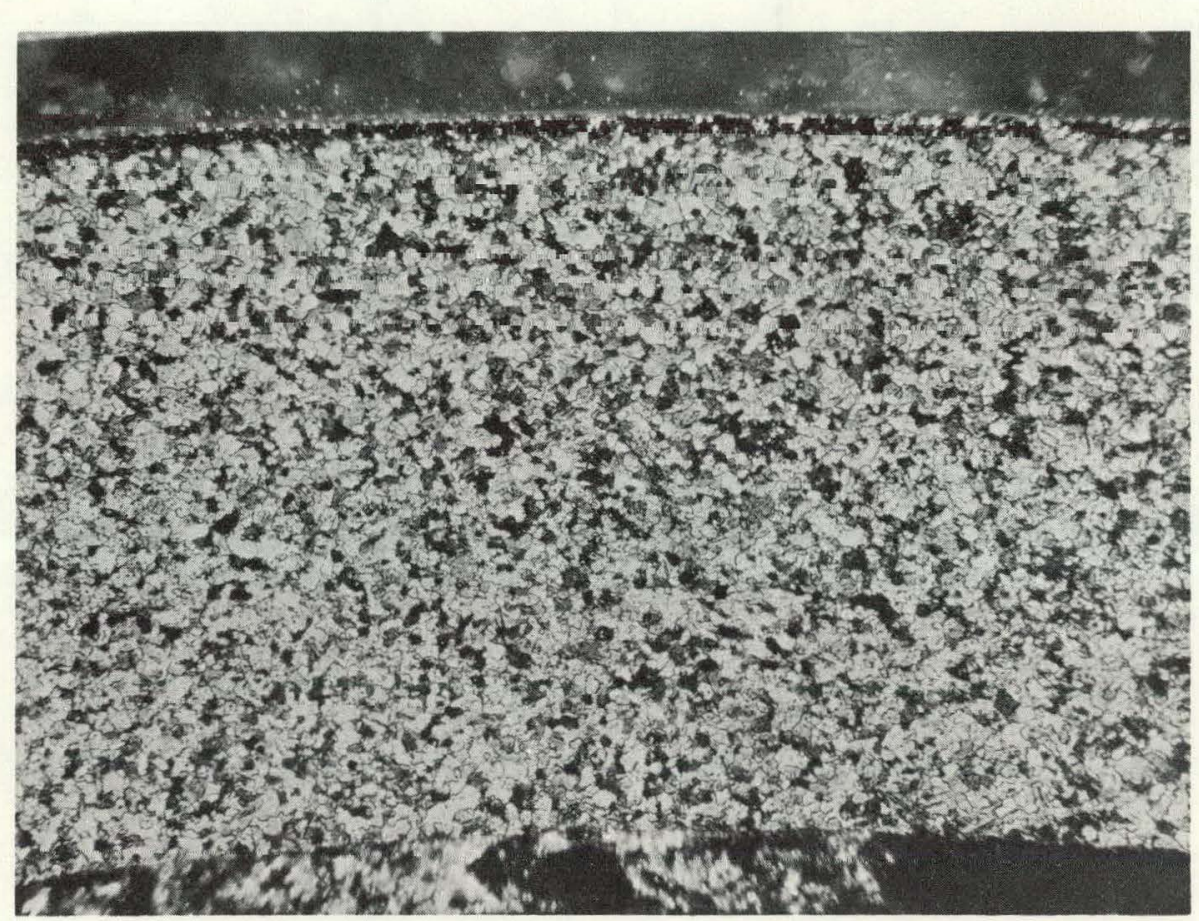

\section{NEG. No. $8716-26$}

$100 x$

REPRESENTATIVE CLADDING SECTION AS SEEN ON PAGL 15, USINC FOLARIZLD LIGHT TO SHOWW GRAIN STRIICTURE.

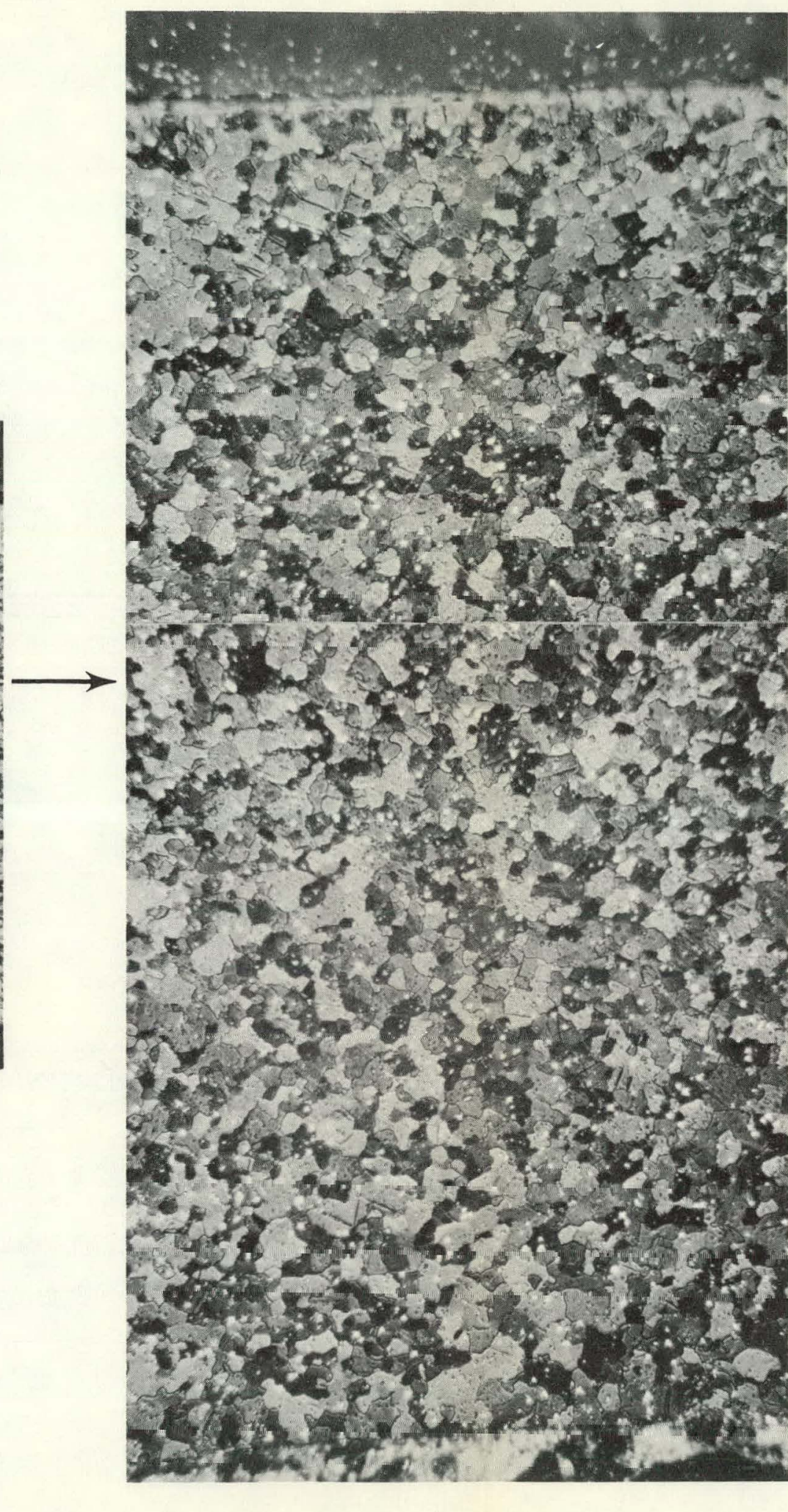

NEG. No. 8716-33/8716-34

250X COMPOSITE OF CLADDING THICKNESS

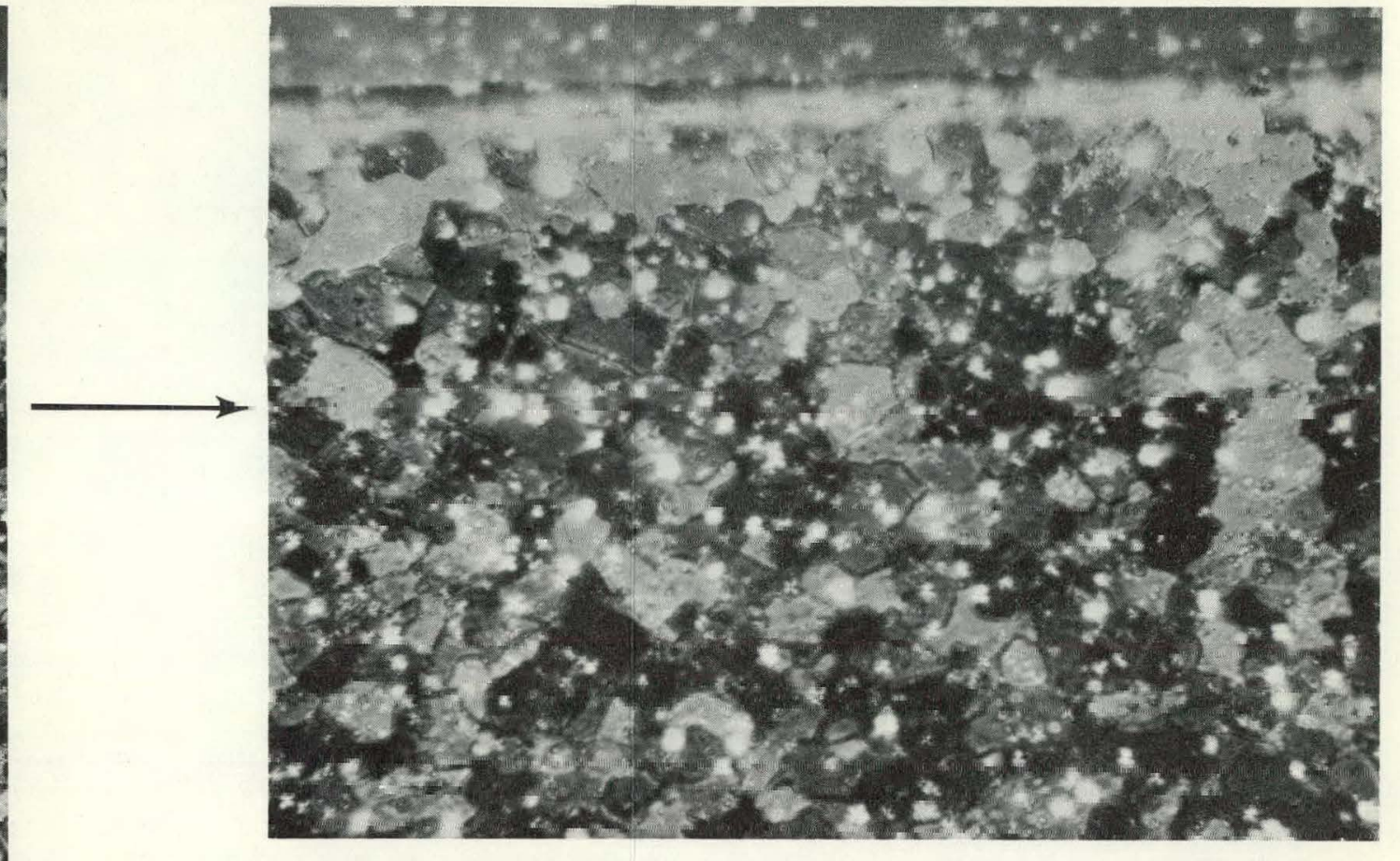

NEG. No. 8716-28 $500 x$ CLAD OUTSIDE DIAMETER SHOWING HYDRIDE

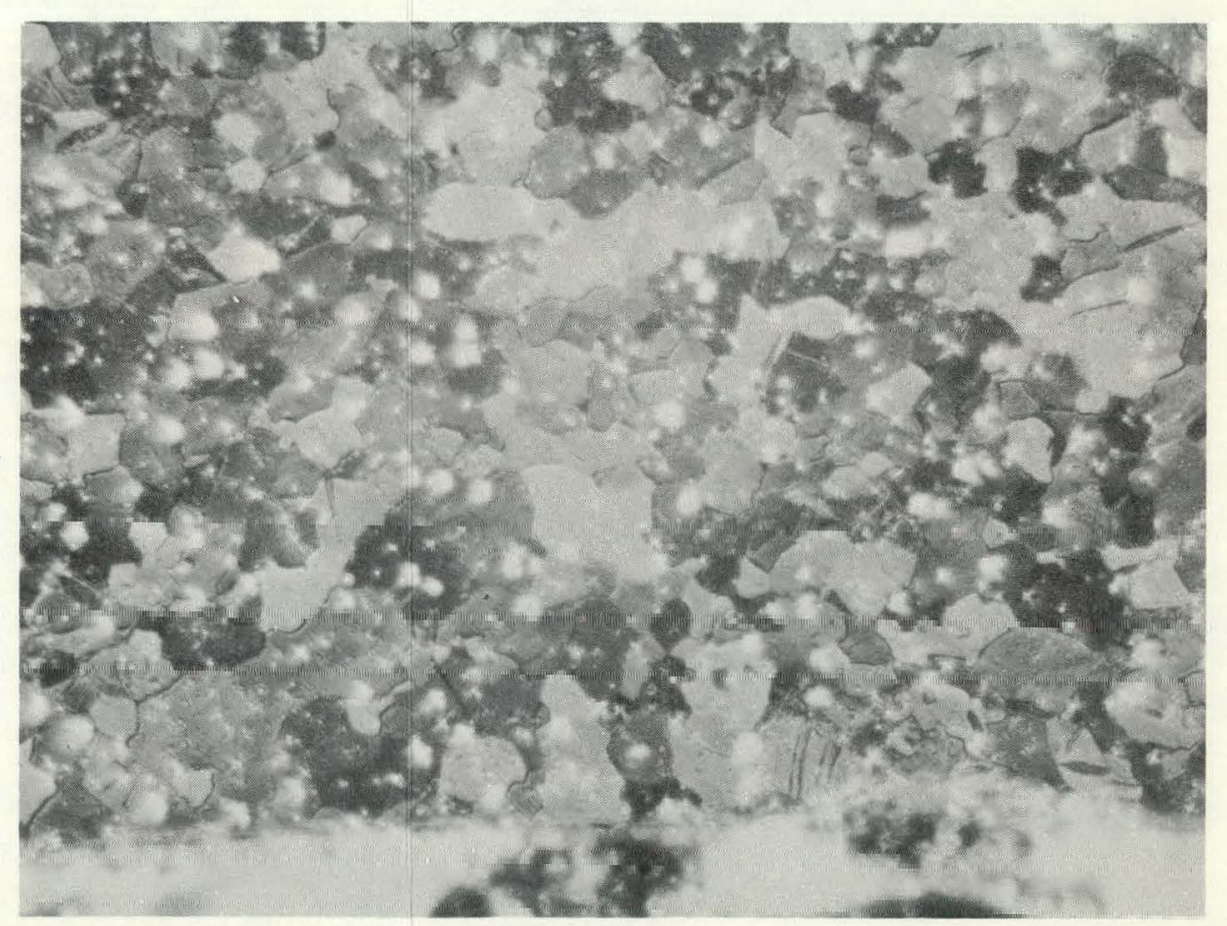

NEG. No. 8716-36 $500 x$ 


\title{
EPT-6 ROD-A
}

\author{
MAXIMUM BURNUP ZONE
}

ROD ELEVATION 191/2 Inches FROM BOTTOM 


\section{ROD ELEVATION 191/2 Inches}

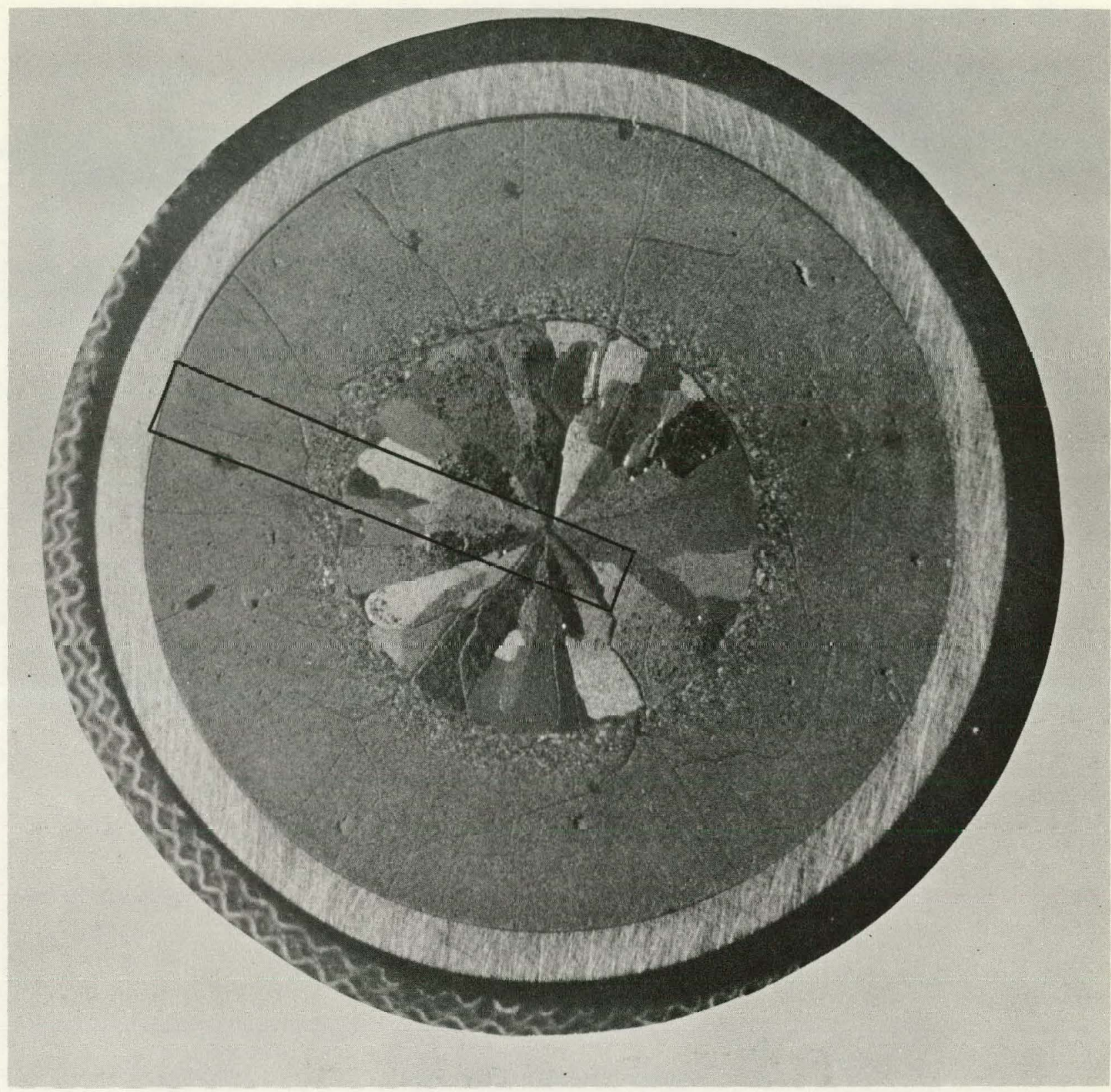

NEG. No. 9010-01 (OFF $600 \mathrm{SiC}$ )

PHOTOMACROGRAPH OF TRANSVERSE FUEL

ROD SECTION AT LOCATION OF MAXIMUM

BURN-UP BETWEEN PELLETS 36 AND 37. 
ROD ELEVATION 191/2 Inches

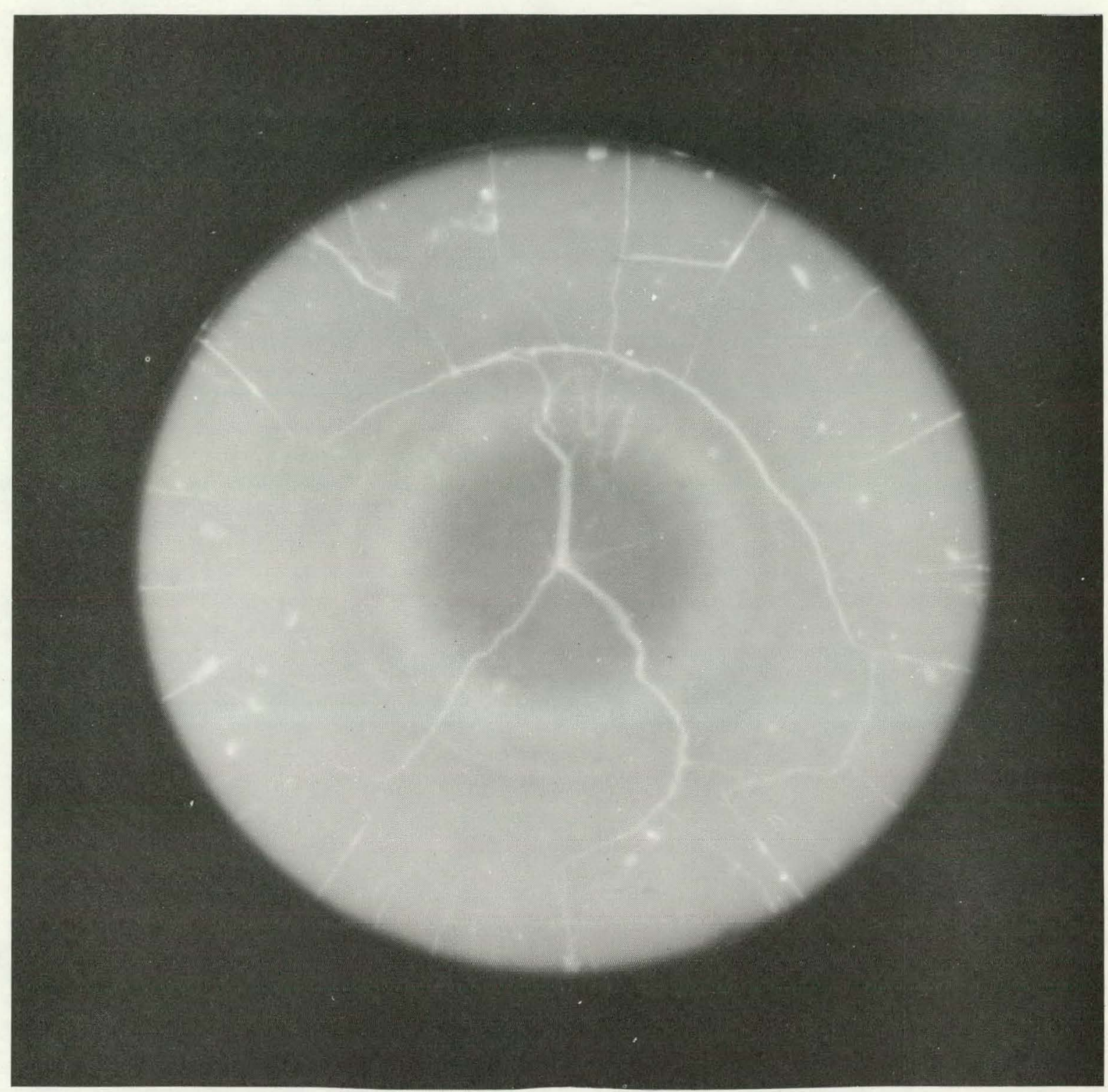

NEG. No. YUIU-U2

$10 \mathrm{X}$

$\beta-\gamma$ AUTORADIOGRAPH OF SAME SECTION AS IN

NEG. No. 9010-01. 
ROD ELEVATION 191/2 Inches

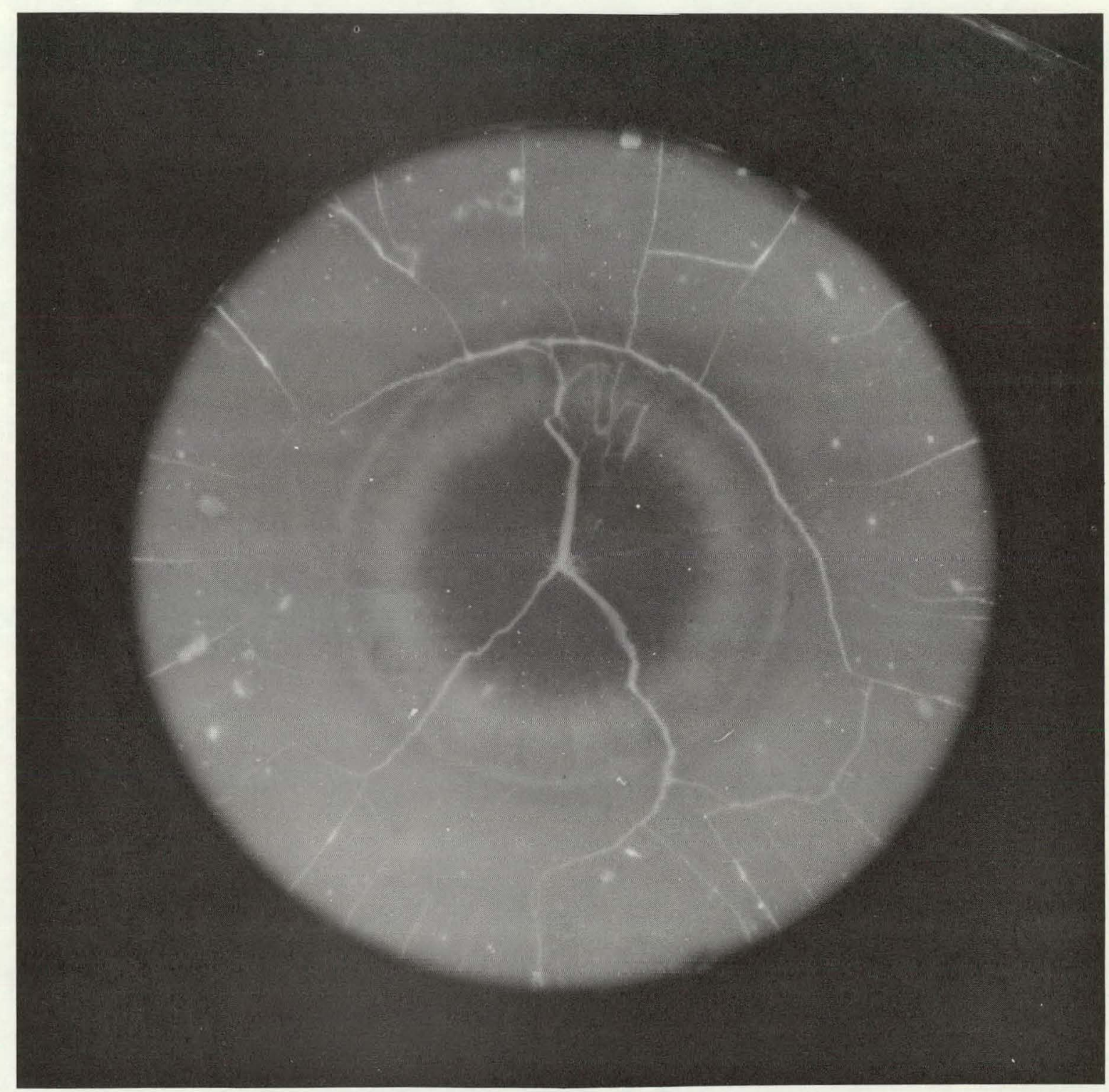

NEG. No. 9010-27

ANOTHER $\beta-\gamma \quad$ AUTORADIOGRAPH OF THE

SECTION SHOWN IN 9010-01 AFTER POLISHING

1000 


$$
x
$$



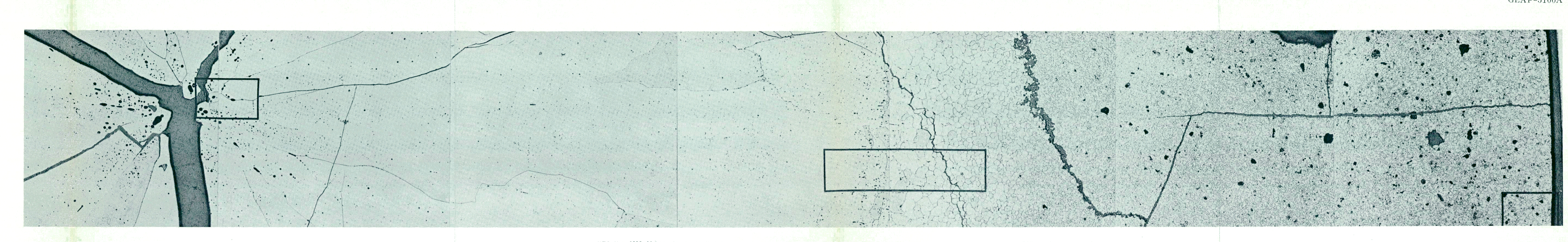

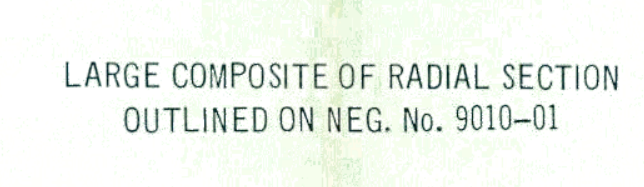

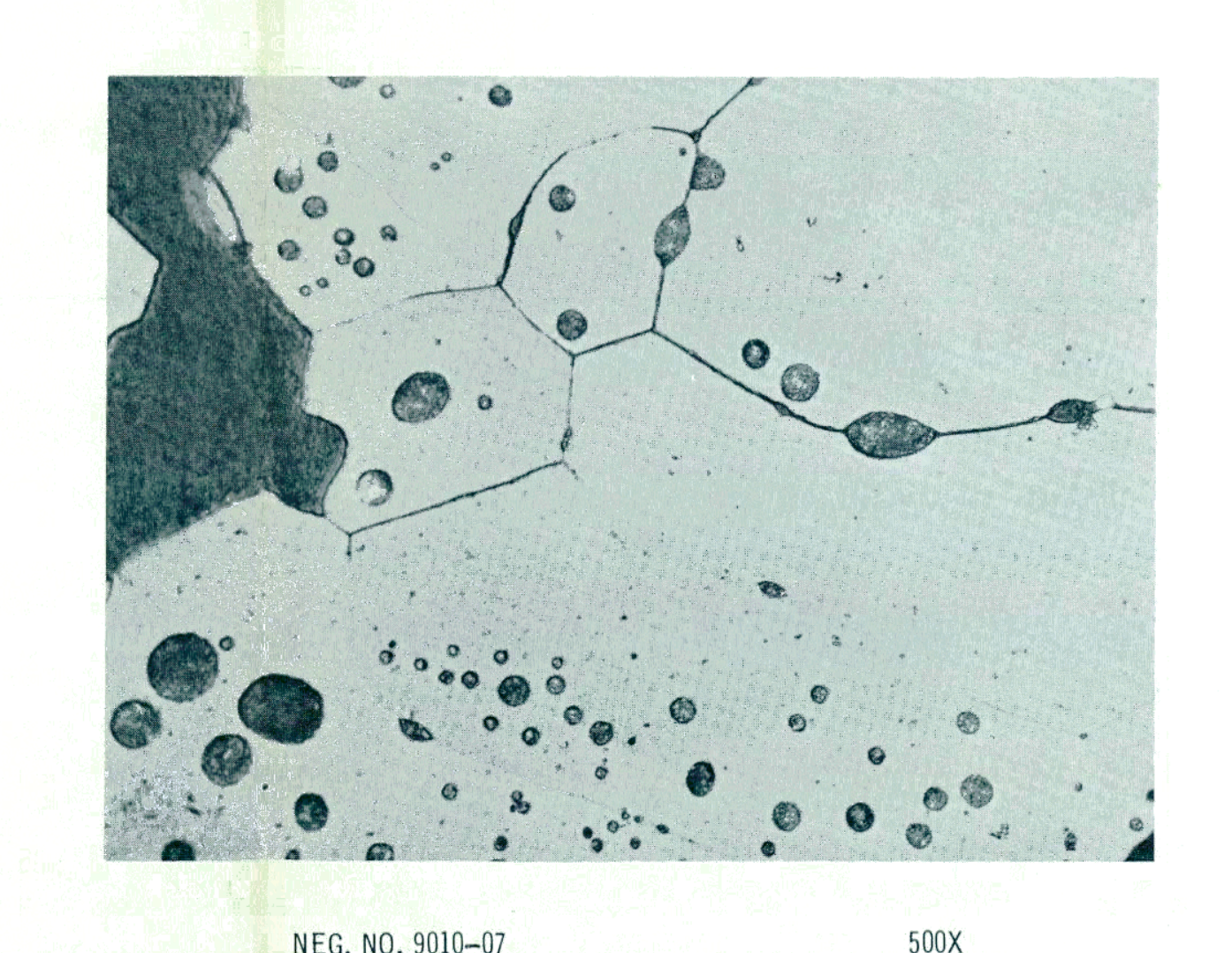

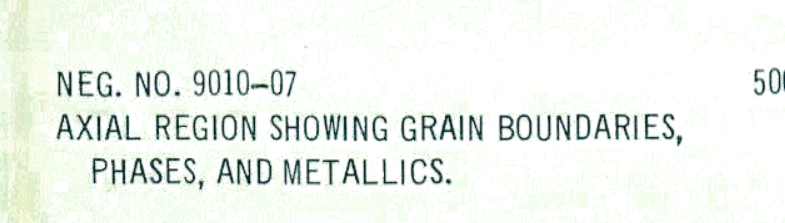

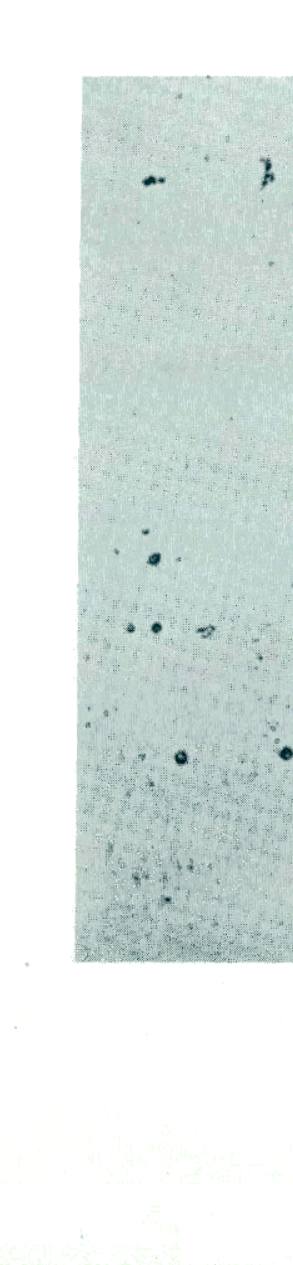

$\therefore$

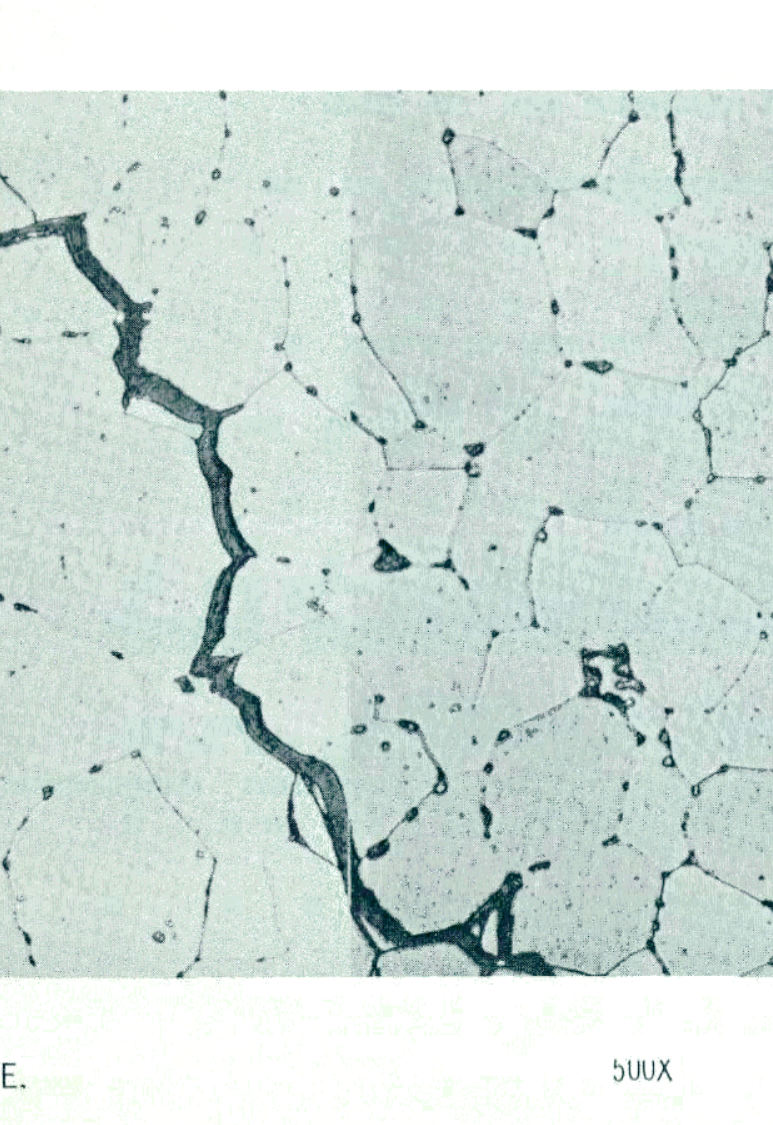

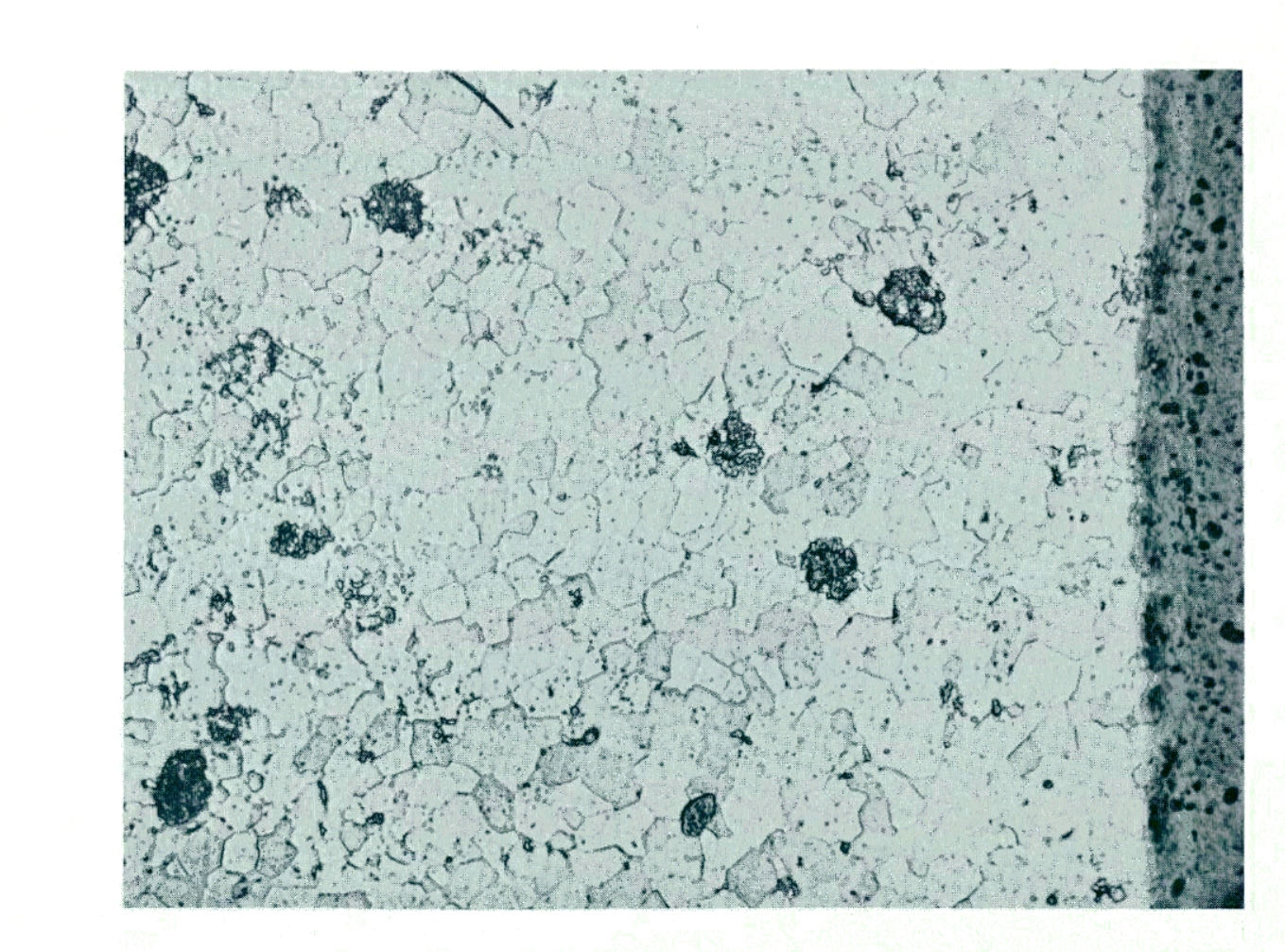




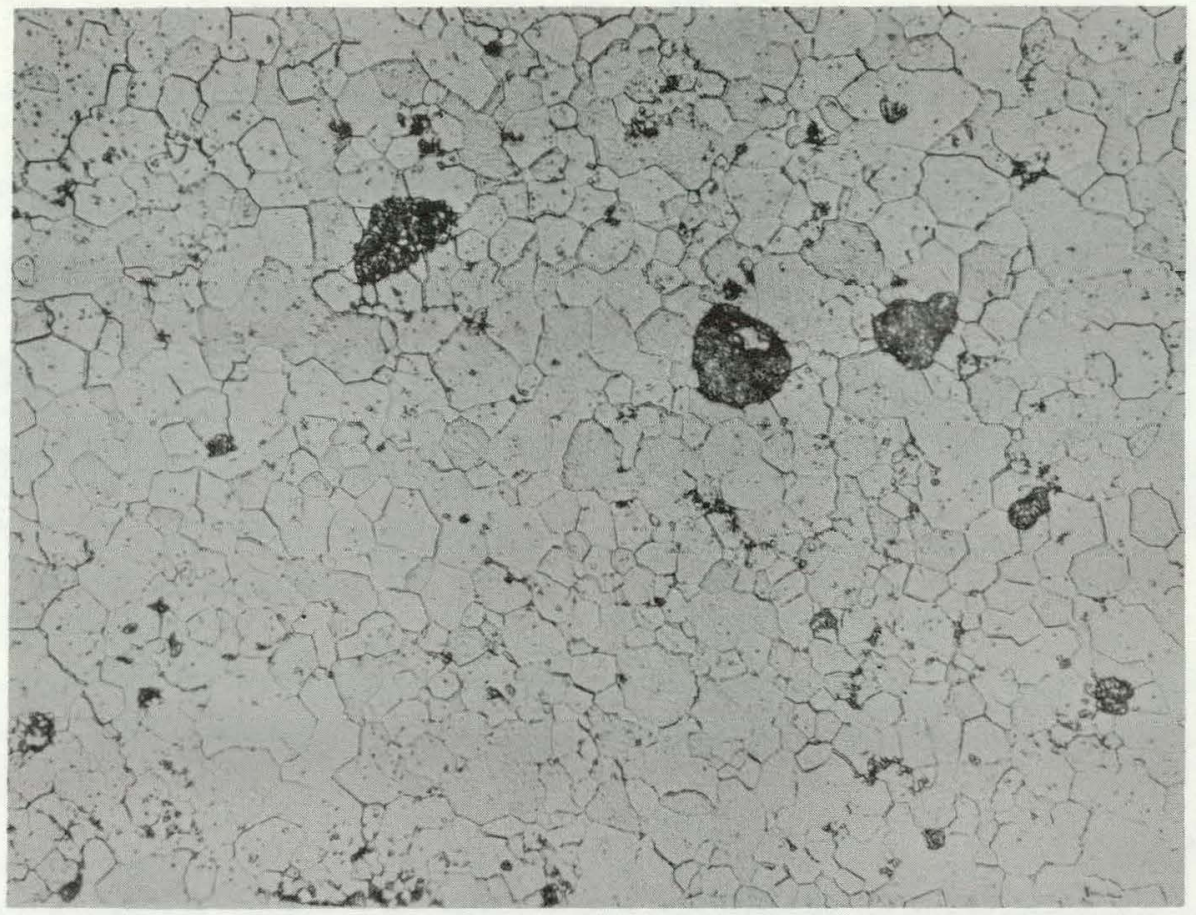

NEG No. 9010-20

$500 X$

"AS SINTERED" GRAIN STRUCTURE NEAR OUTSIDE DIAMETER.

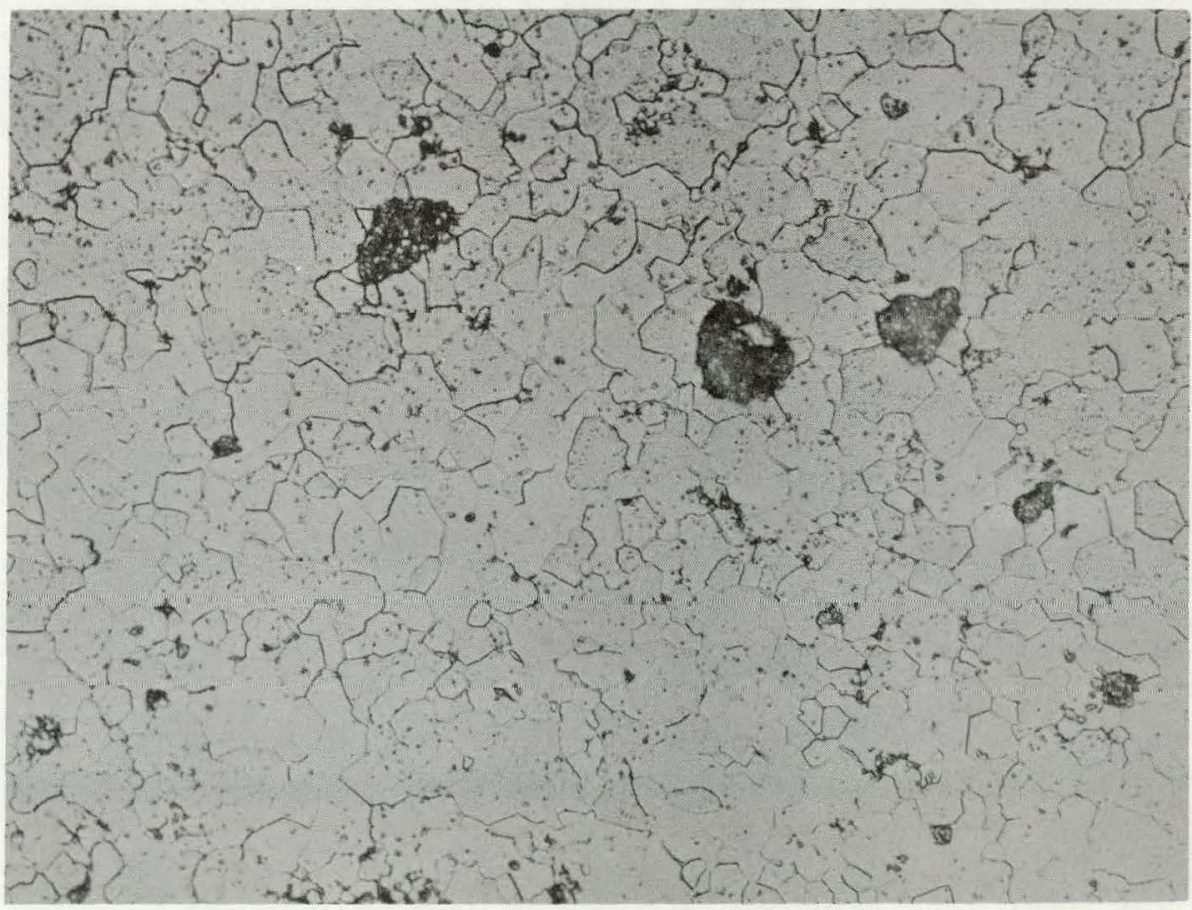

NEG. No. 9010-21 (ETCHED)

$500 x$

"AS SINTERED" GRAIN STRUCTURE NEAR OUTSIDE DIAMETER, ANOTHER VIEW. 


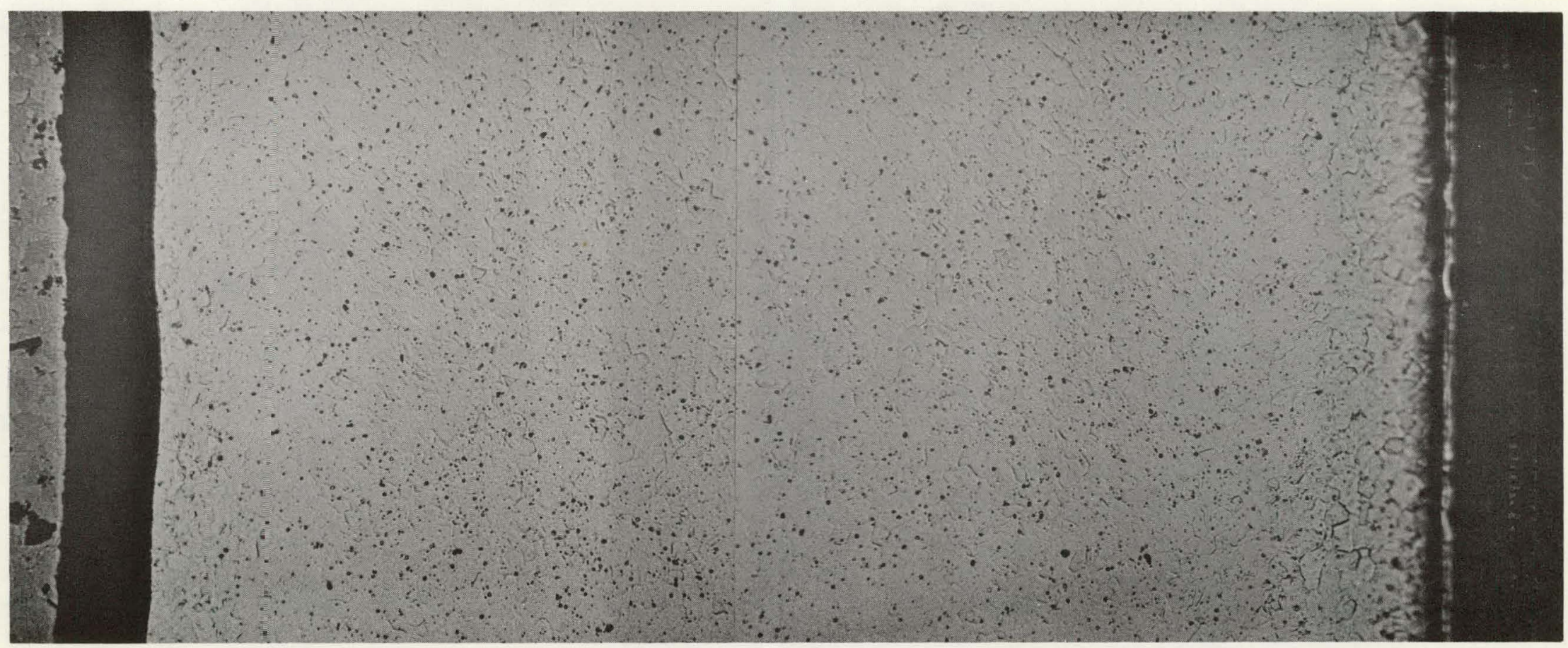

NEG. №. 9010-22/9010-23 (ETCHED)

250X

COMPOSITE OF CLADDING WALL SHOWING GRAIN BOUNDARIES. 


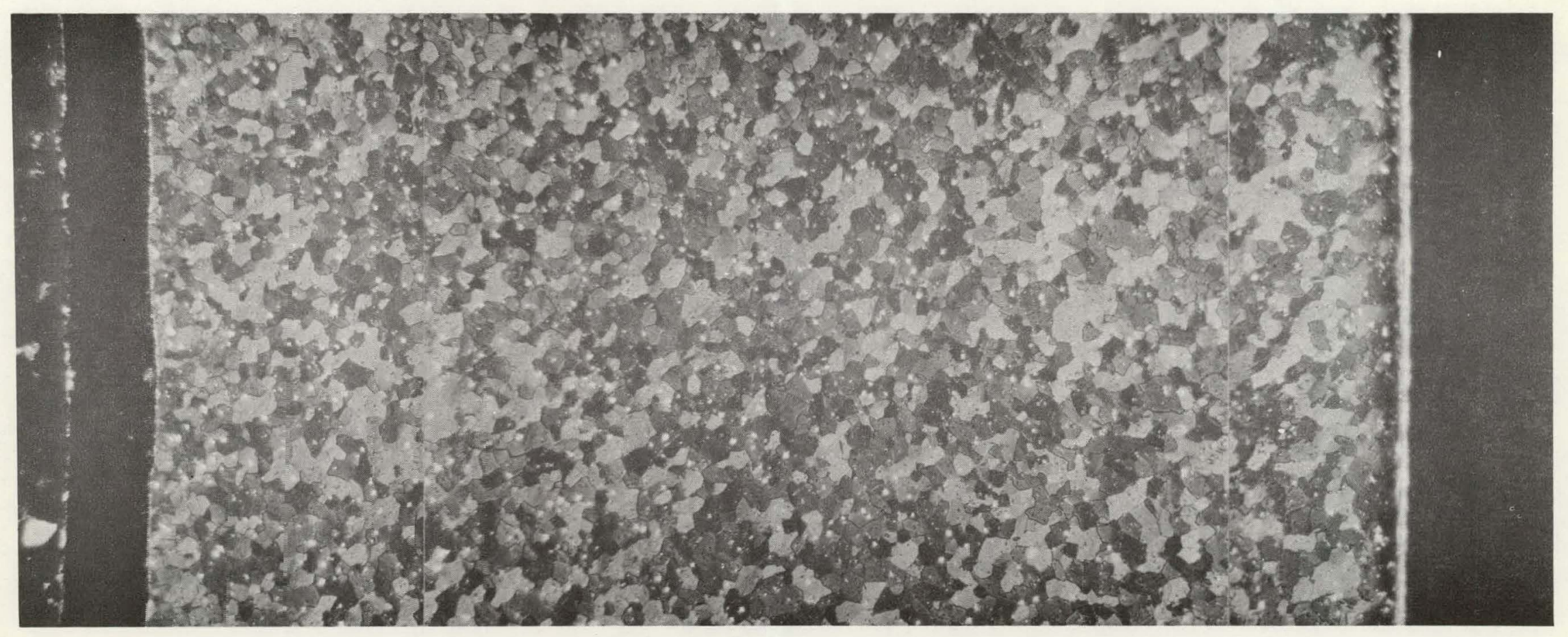

NEG. No. 9010-24/9010-26 (ETCHED)

$250 X$

COMPOSITE OF SAME PART OF CLADDING WALL AS SHOWN PREVIOUS PAGE USING POLARIZED LIGHT TO BETTER SHOW GRAIN STRUCTURE. 


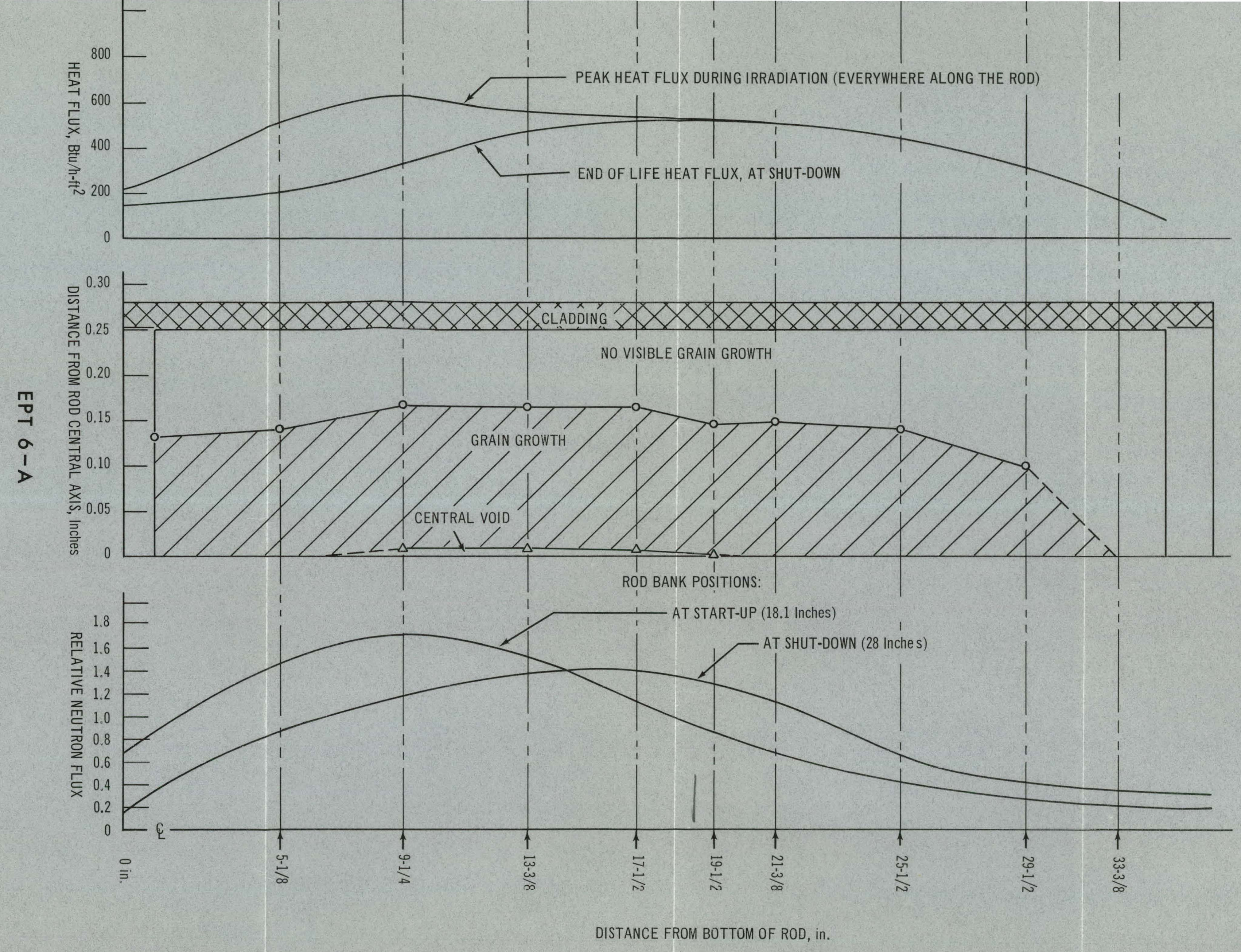




\title{
EPT-6 ROD-D
}

\author{
FRACTURE SECTIONS
}


ROD ELEVATION $45 / 8$ Inches

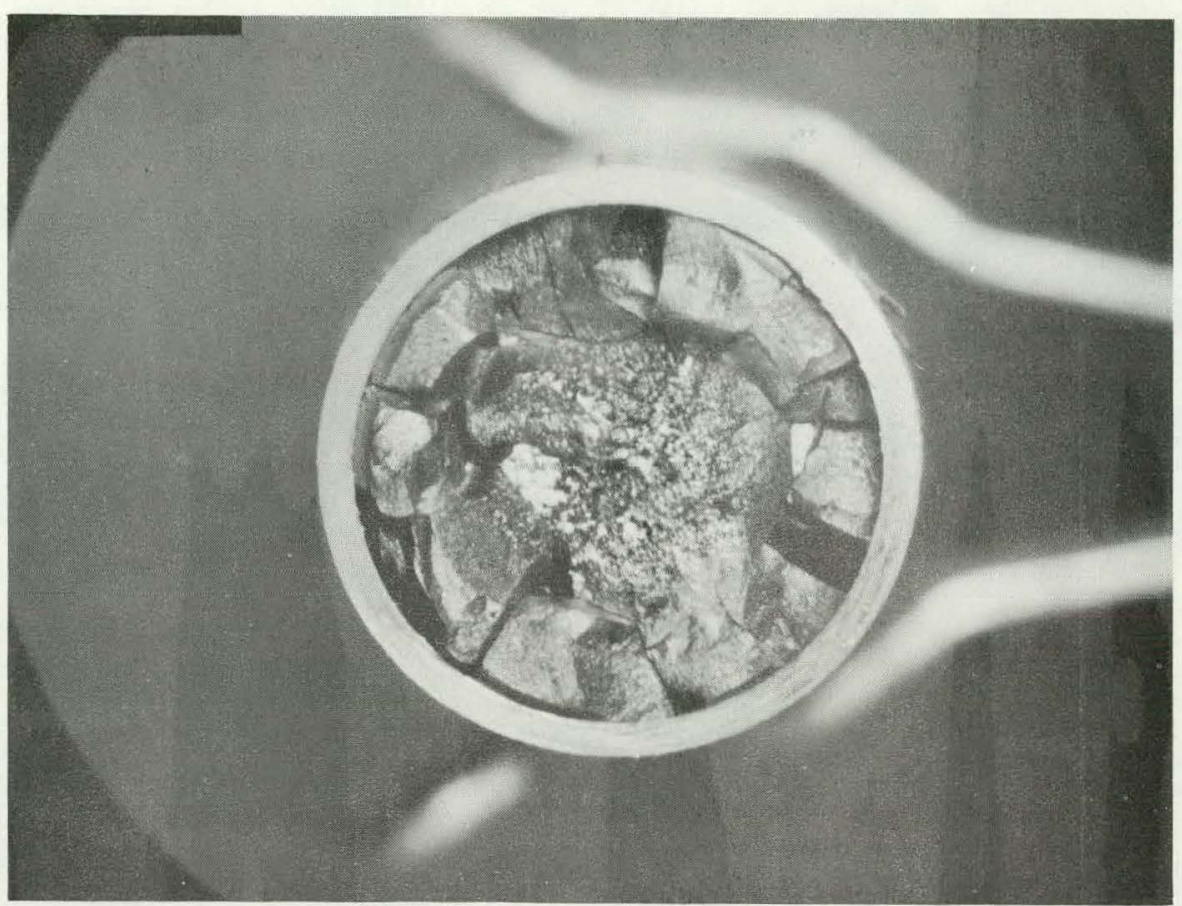

NEG. No. 19211

$4 X$

BOTTOM OF PELLET 8.

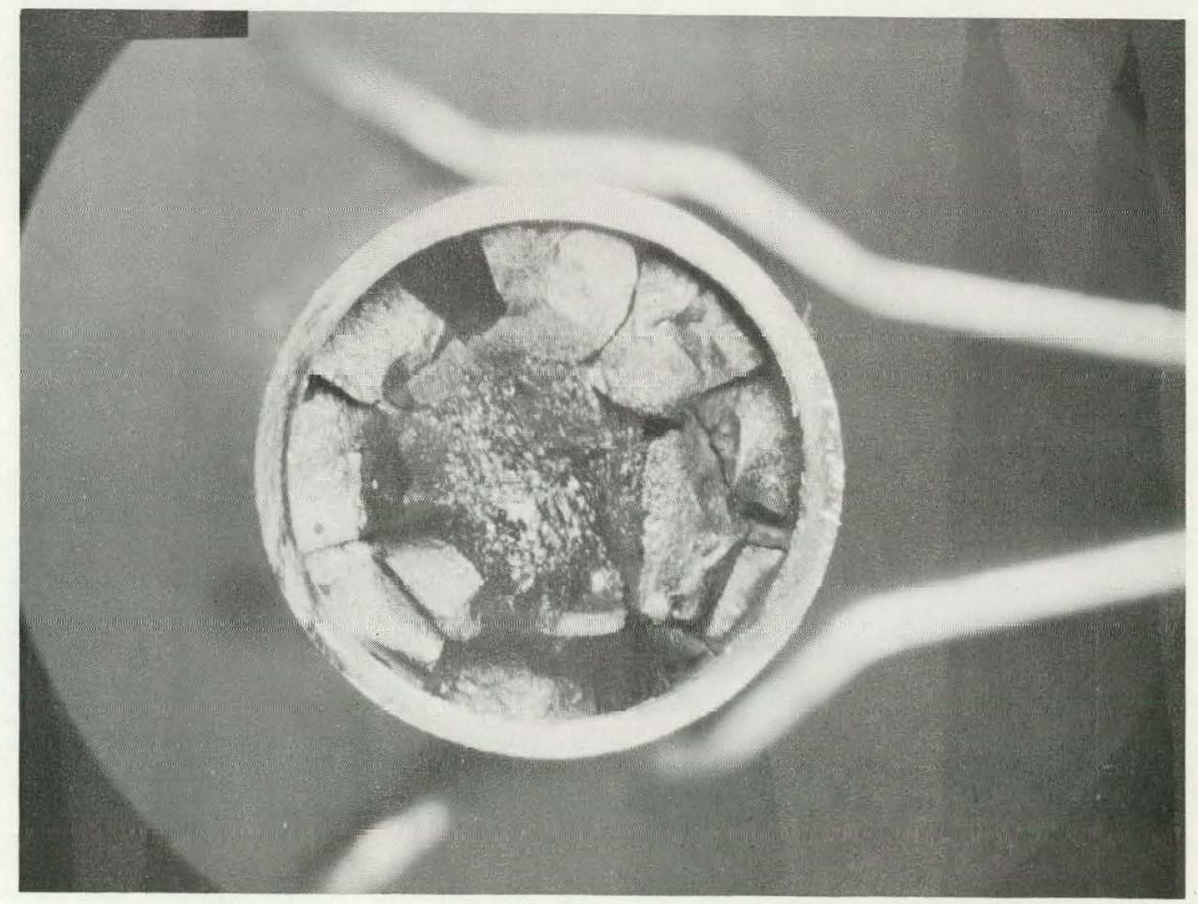

NEG. No. 19212

$4 X$

TOP OF PELLET 7. 


\section{ROD ELEVATION 5-71/2 Inches}

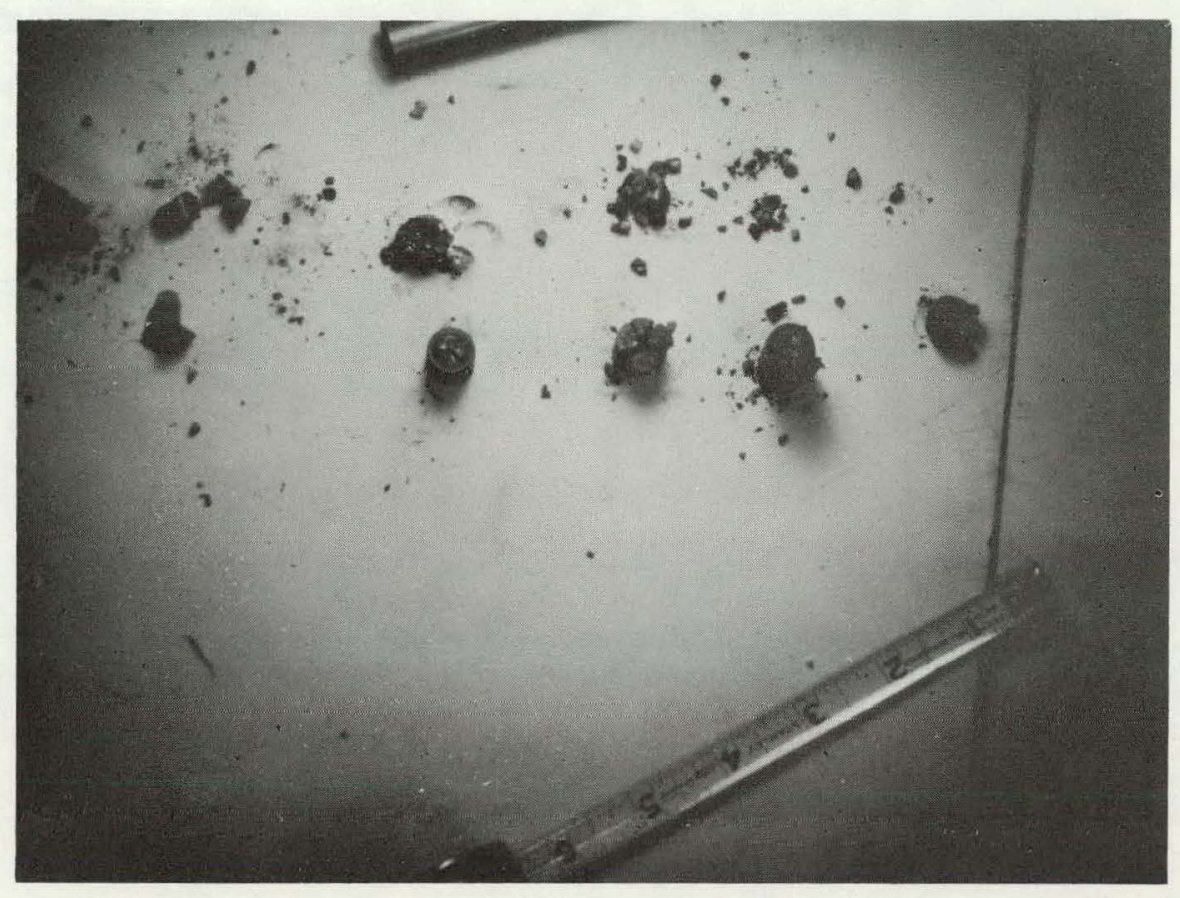

NEG. No. 19148

$1 / 4 X$

FUEL PELLETS 9-13 AS SEPARATED. 
ROD ELEVATION 5/2 In.

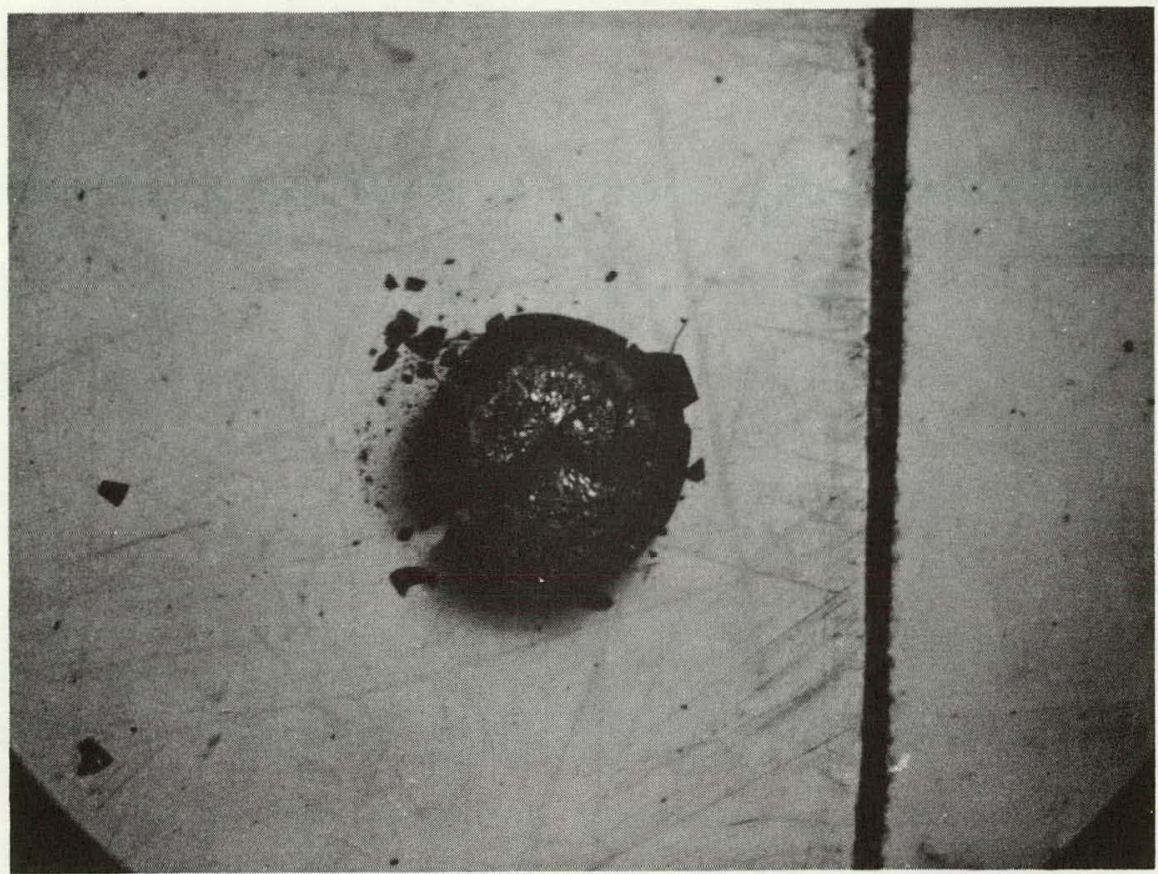

NEG. No. 19152

$3 / 2 X$

MIDDLE OF PELLET 9.

ROD ELEVATION 5-3/4 In.

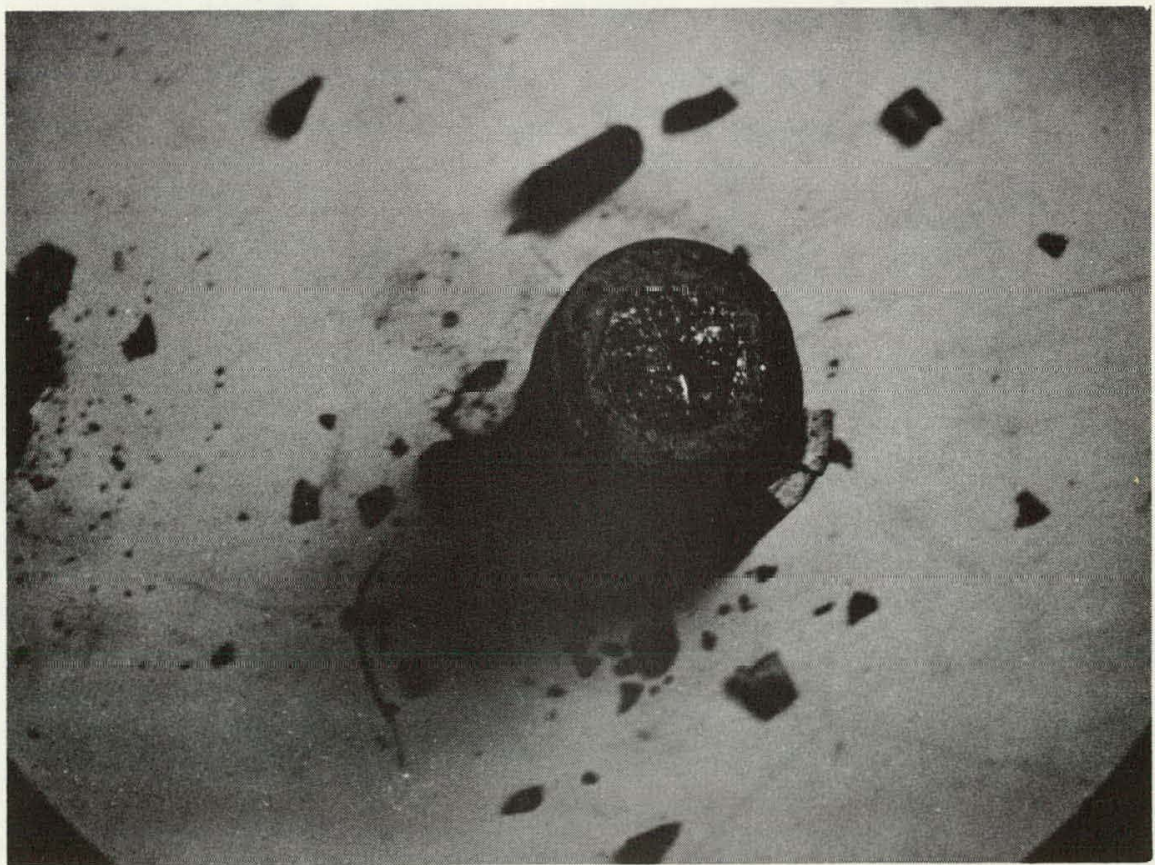

NEG. No, 19151

$3 / 2 X$

PELLETS Nos. $10 \& 11$, SHOWING THE BOTTOM OF PELLET 10. 


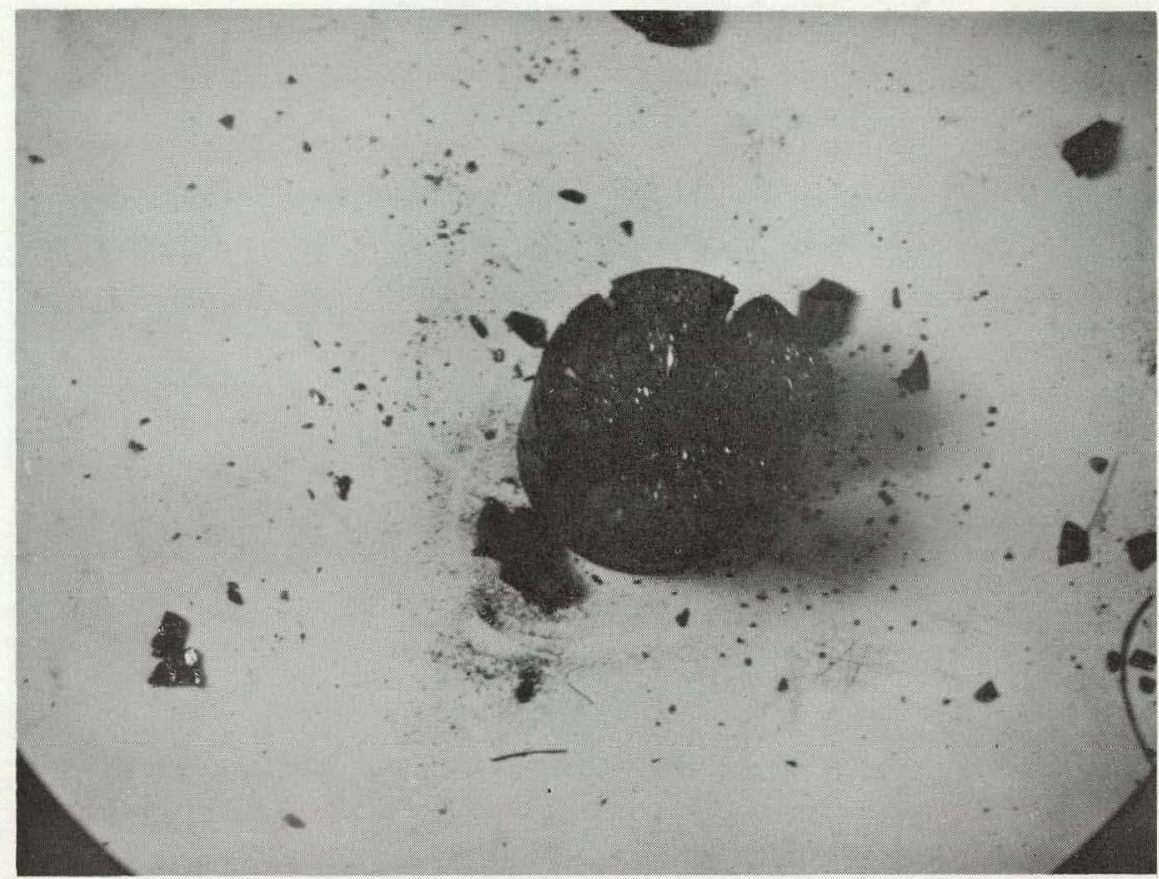

NEG. No. 19150

$3 / 2 x$

BOTTOM OF PELLET 12.

ROD ELEVATION $63 / 8 \mathrm{In.} 7 \mathrm{ln}$.

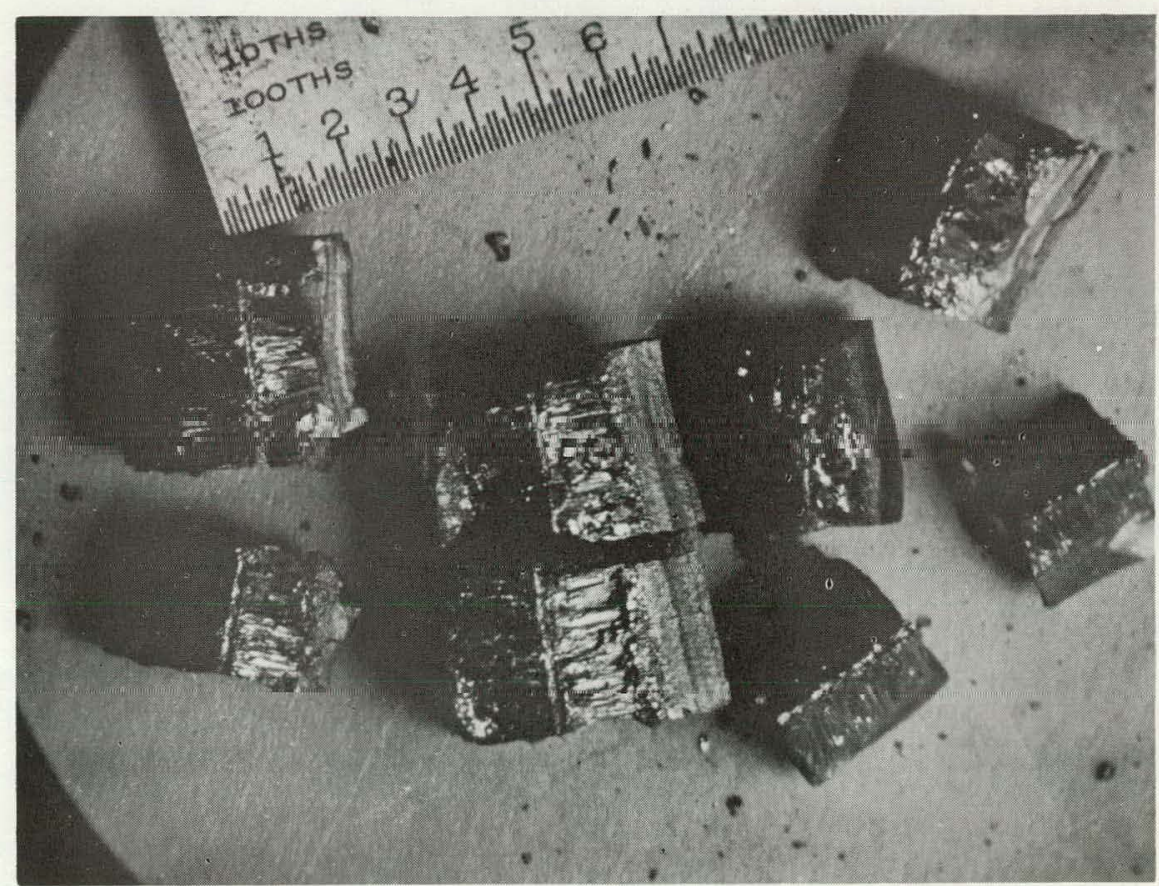

NEG. No. 19153

$5 / 2 X$

LONGITUDINAL DIVISION OF PELLET 12. 
ROD ELEVATION 7 Inches

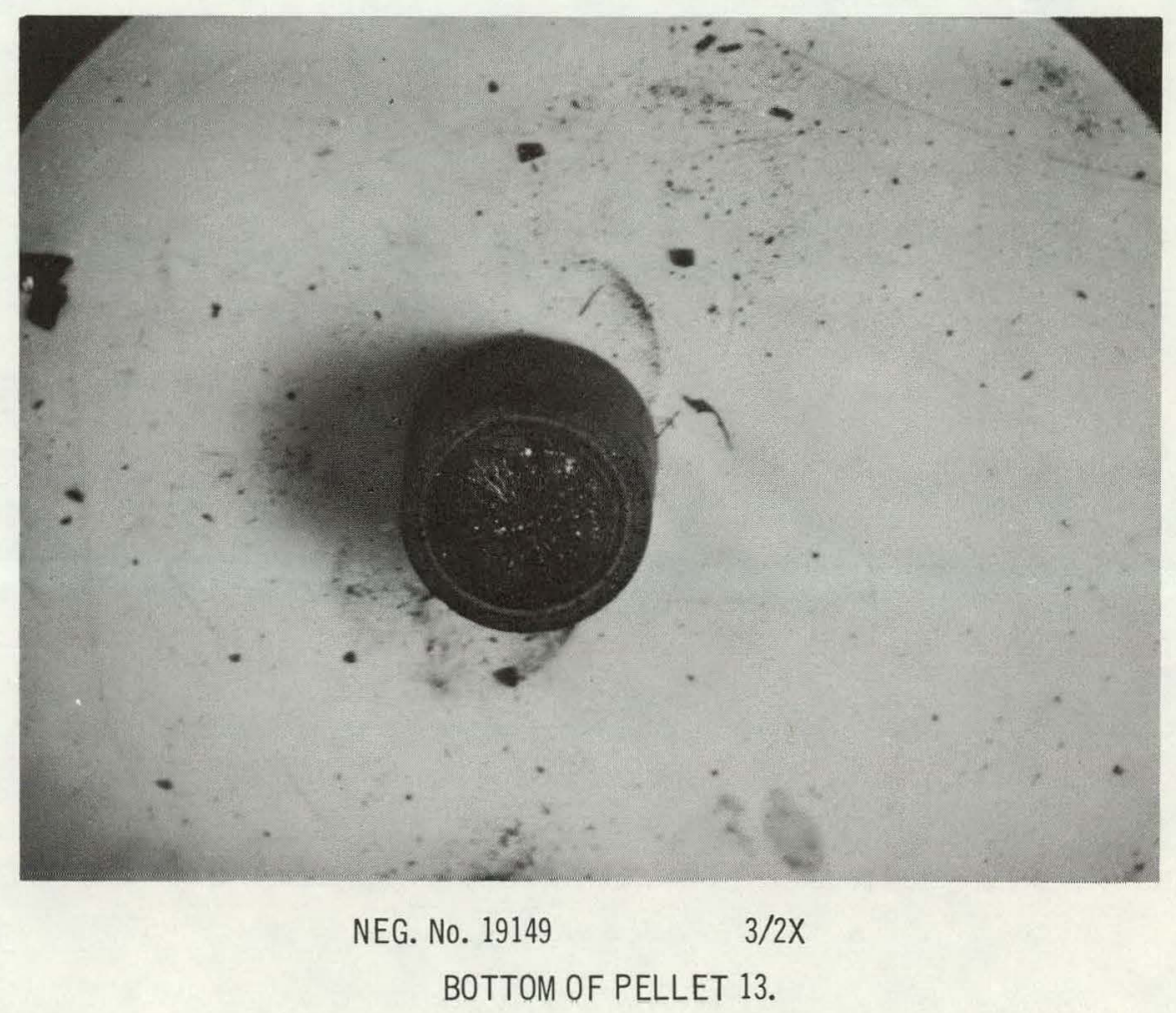


ROD ELEVATION 71/2 Inches

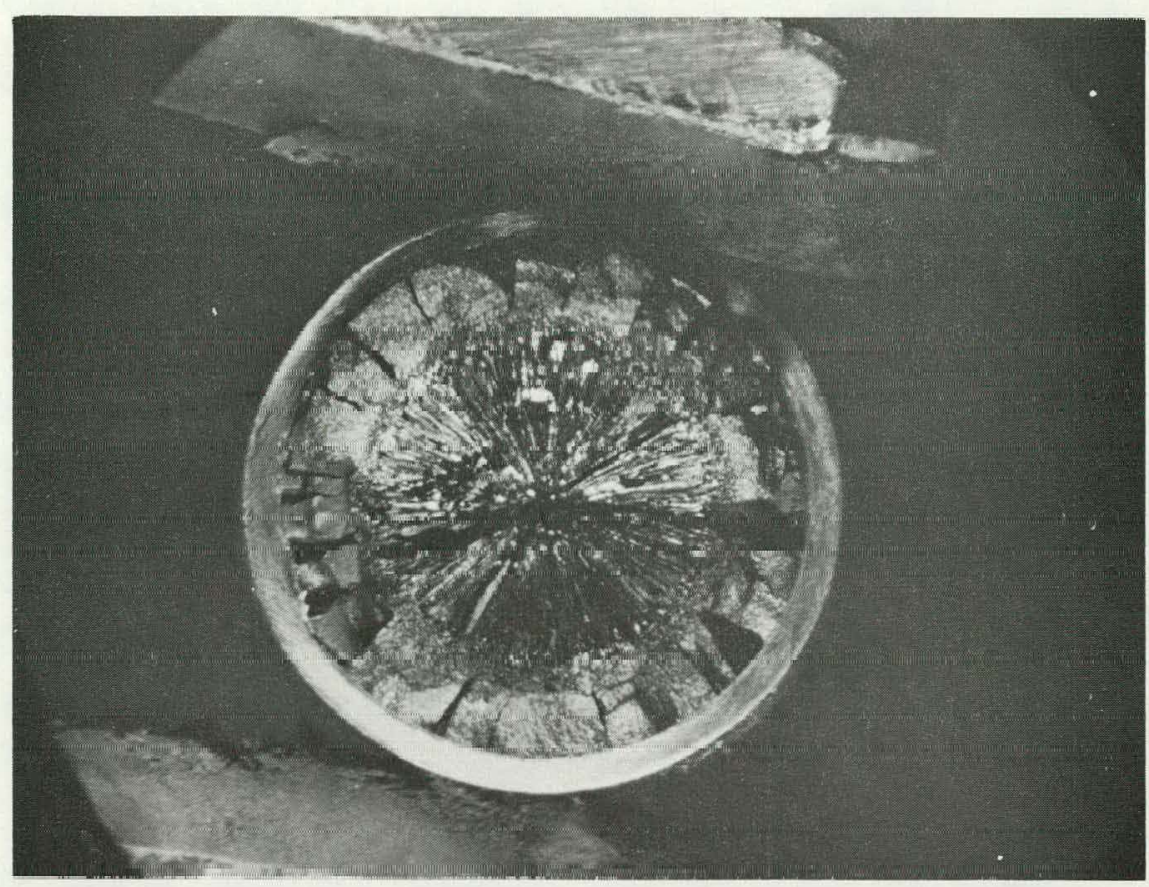

NEG. No. 19126

$4 X$

BOTTOM OF PELLET 14.

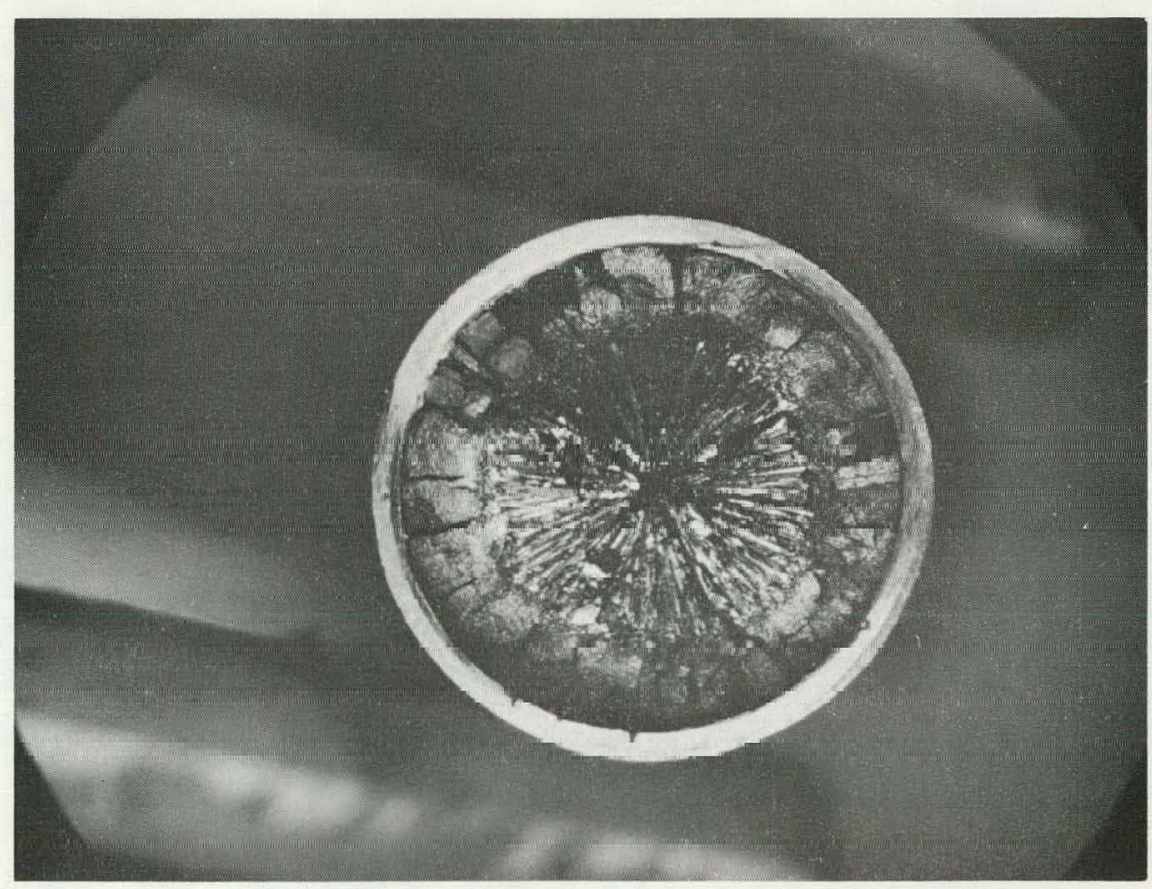

NEG. No. 19127

$4 X$

TOP OF PELLET 13. 
ROD ELEVATION 8 Inches

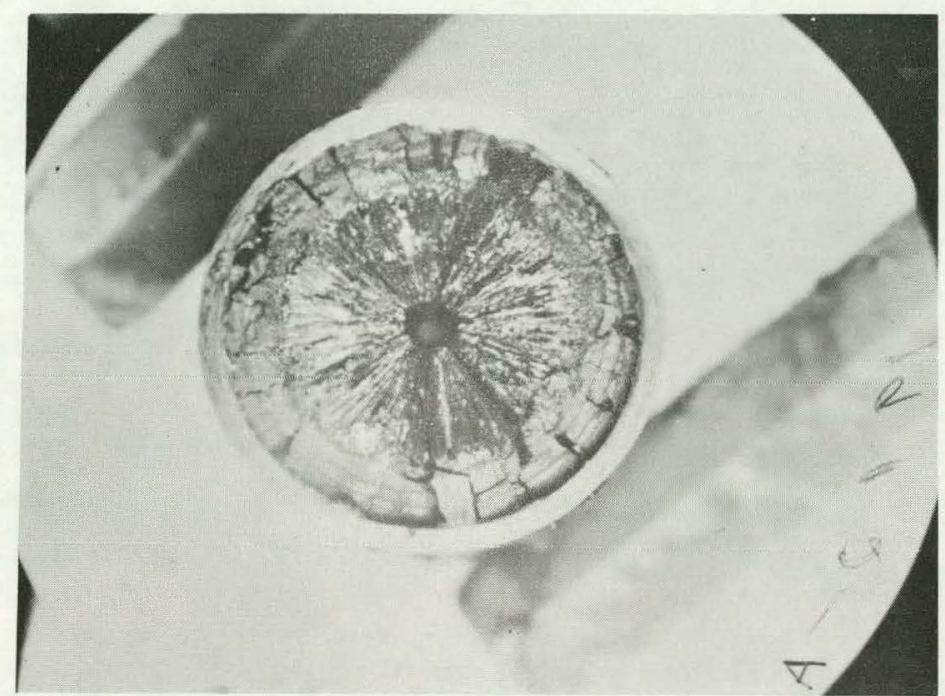

NEG. No. 19125

$4 X$

BOTTOM OF PELLET 14.

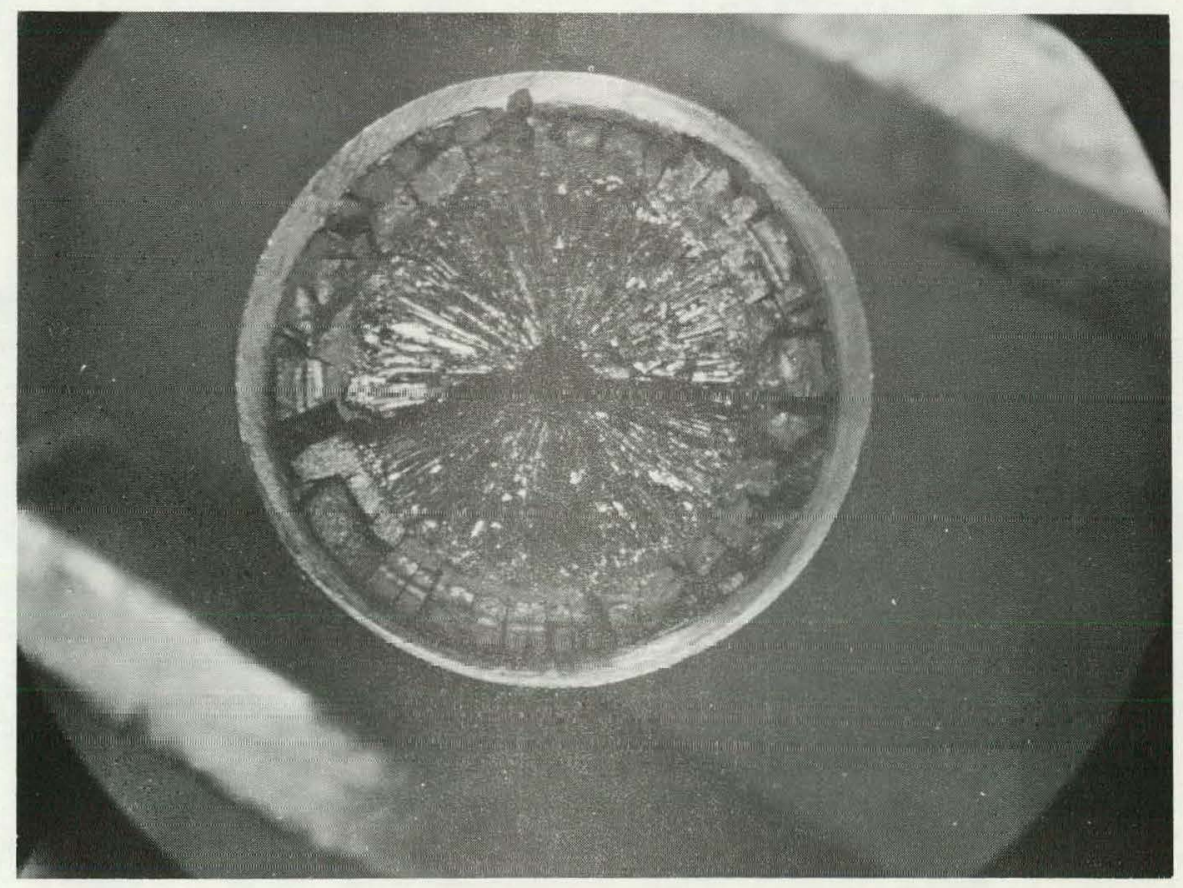

NEG. No. 19124

$4 x$

IUP UF PELLET 16. 


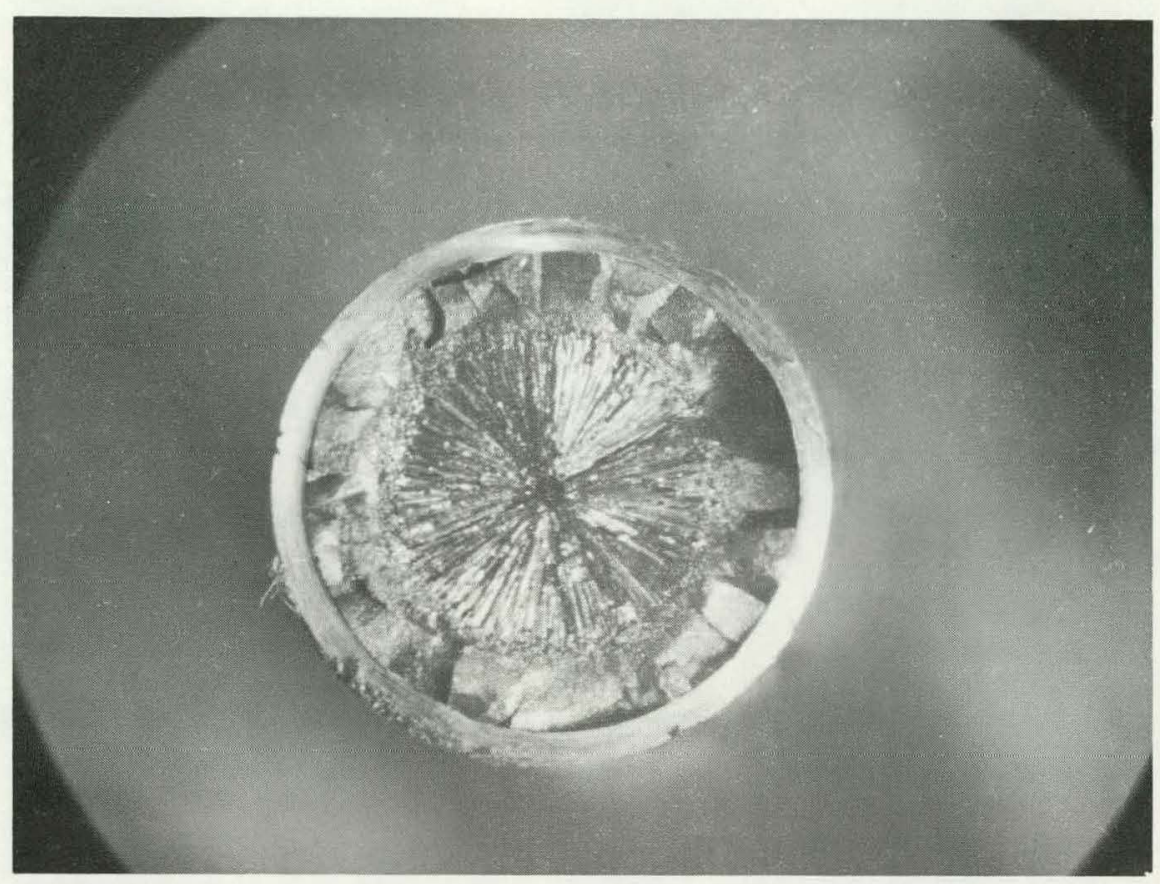

NEG. No. 19123

$3 x$

BOTTOM OF PELLET 20.

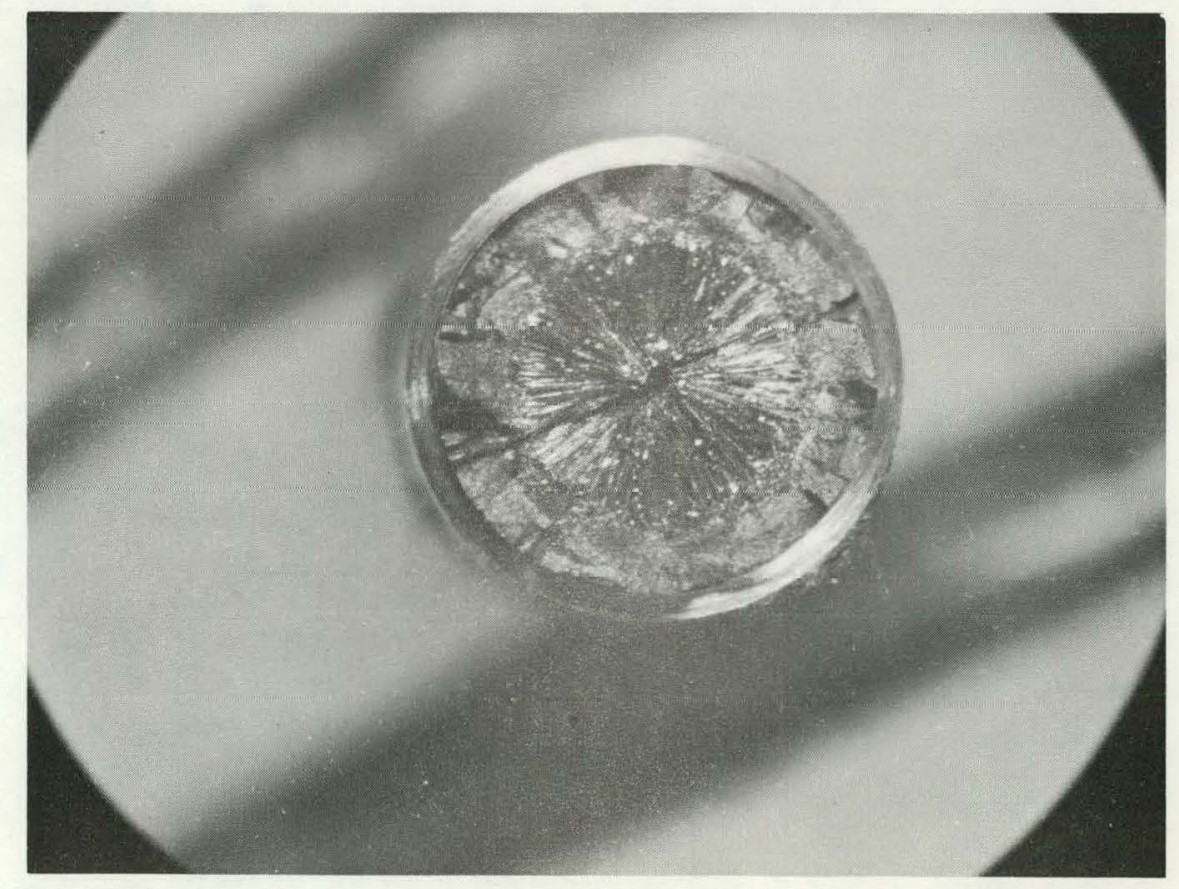

NEG. No. 19122 $3 x$

TOP OF PELLET 19. 
ROD ELEVATION 14 Inches

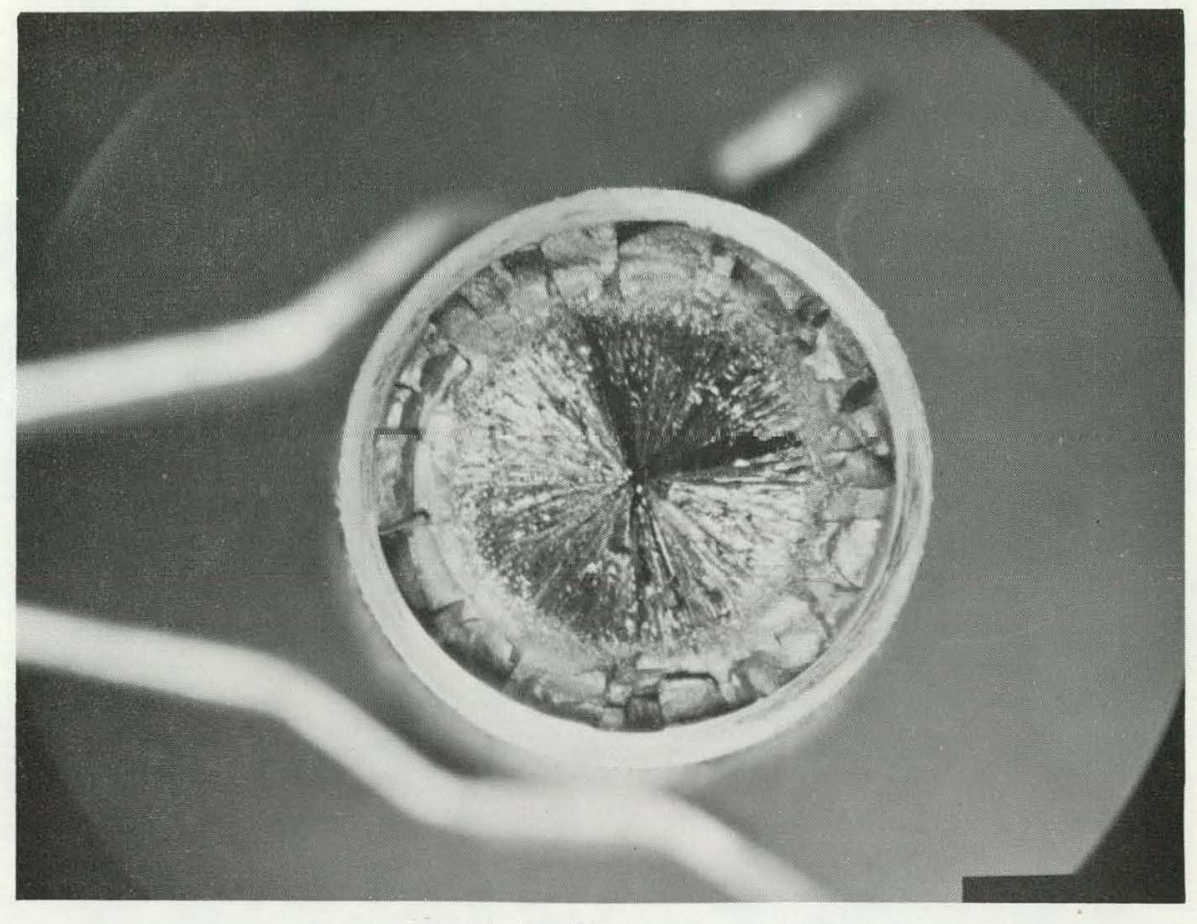

NEG. No. 19213

$4 X$

BOTTOM OF PELLET 27

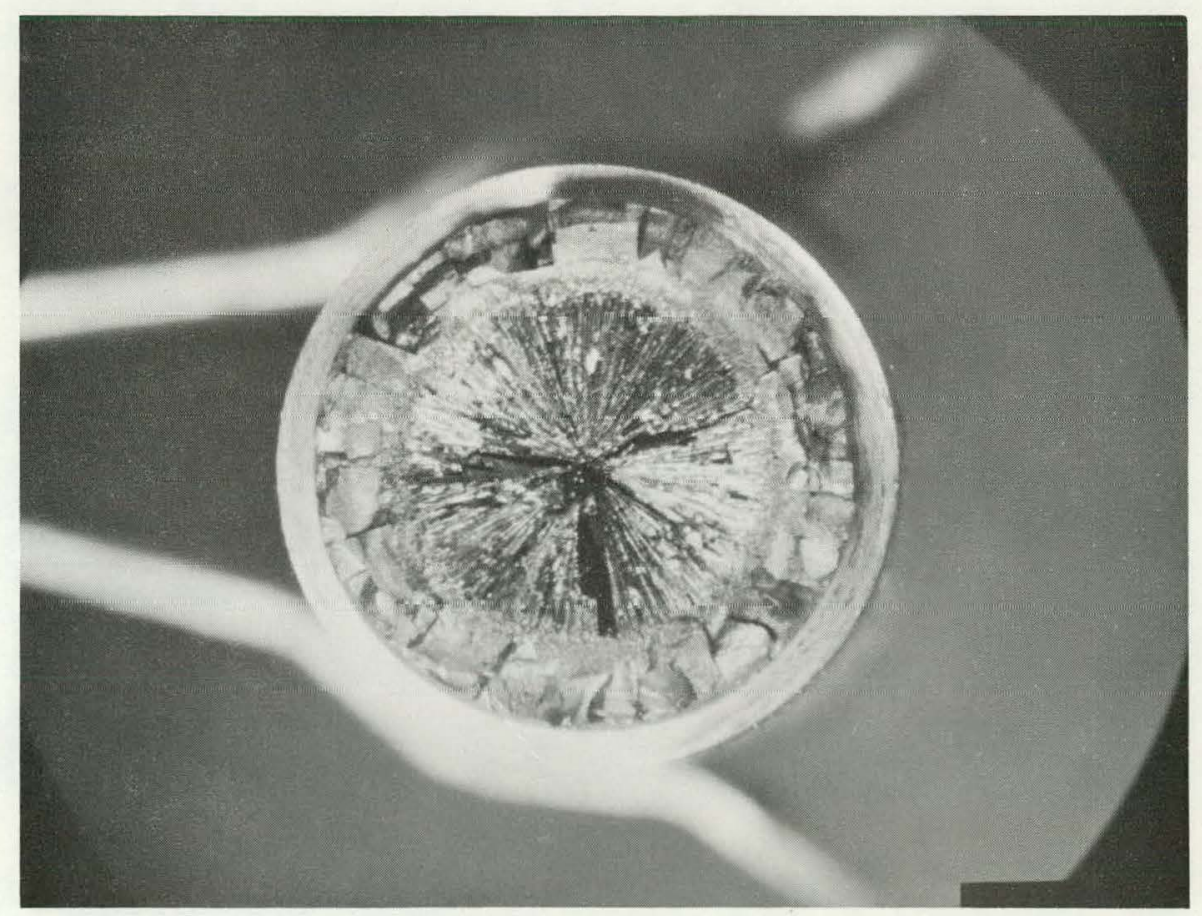

NEG. No. 19214

$4 \mathrm{X}$

TOP OF PELLET 26. 
GEAP-5100A

ROD ELEVATION 18 Inches

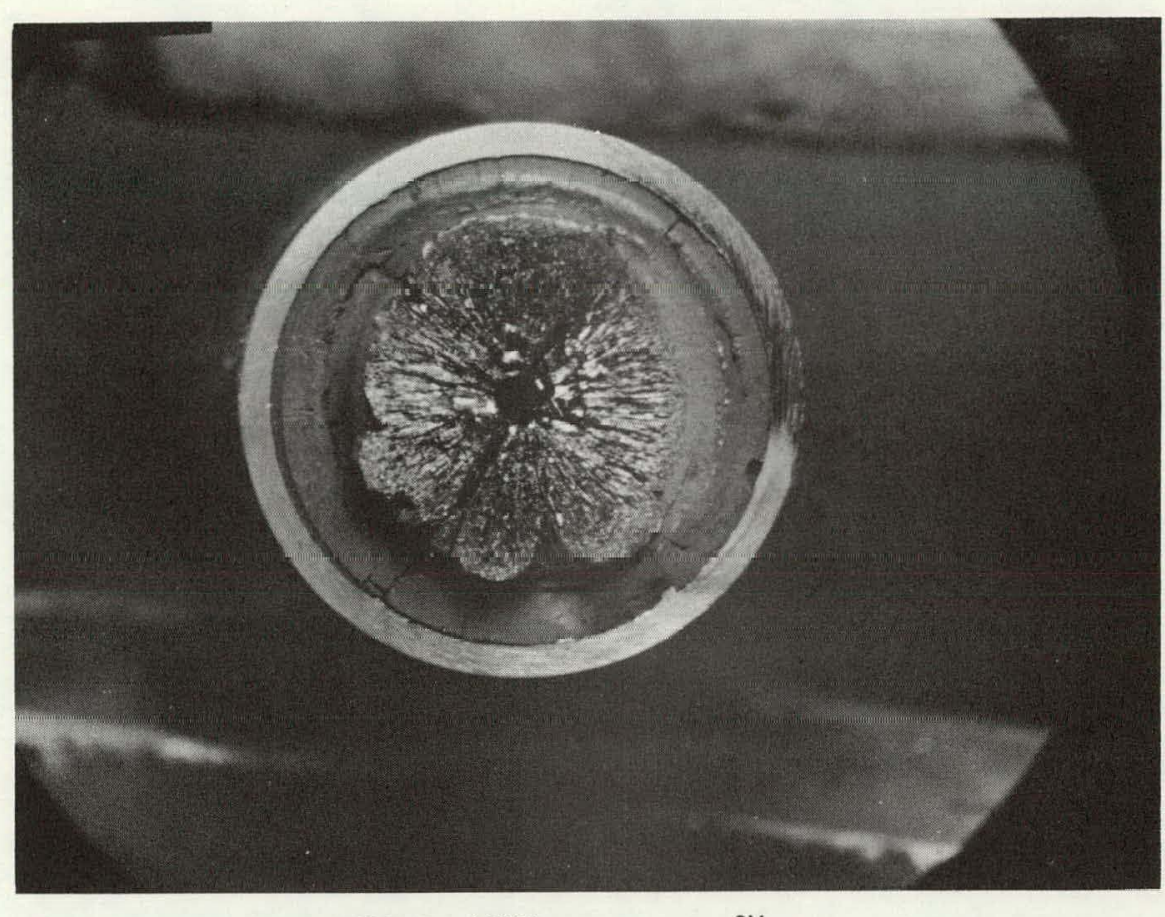

NEG. No. 19131

$3 x$

BOTTOM OF PELLET 34.

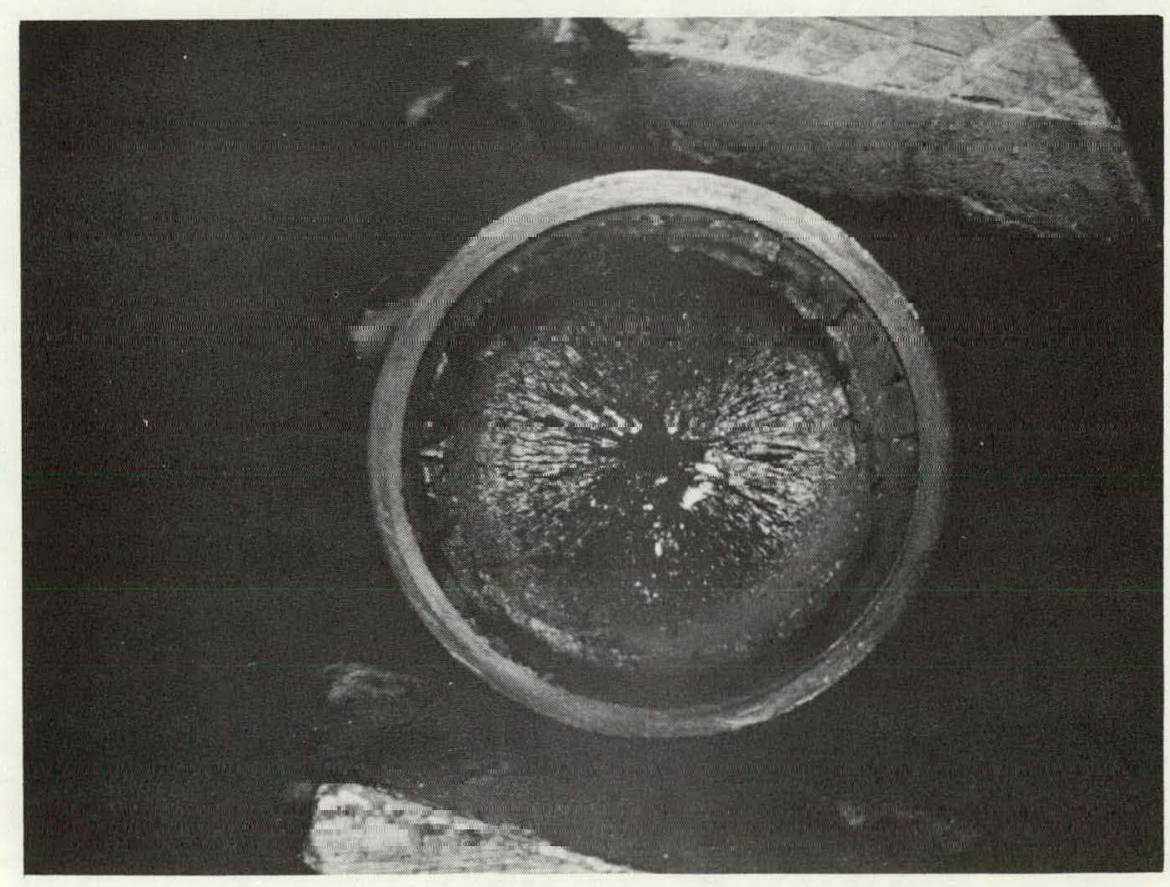

NEG. No. 19130

$3 x$

TOP OF PELLET 33. 


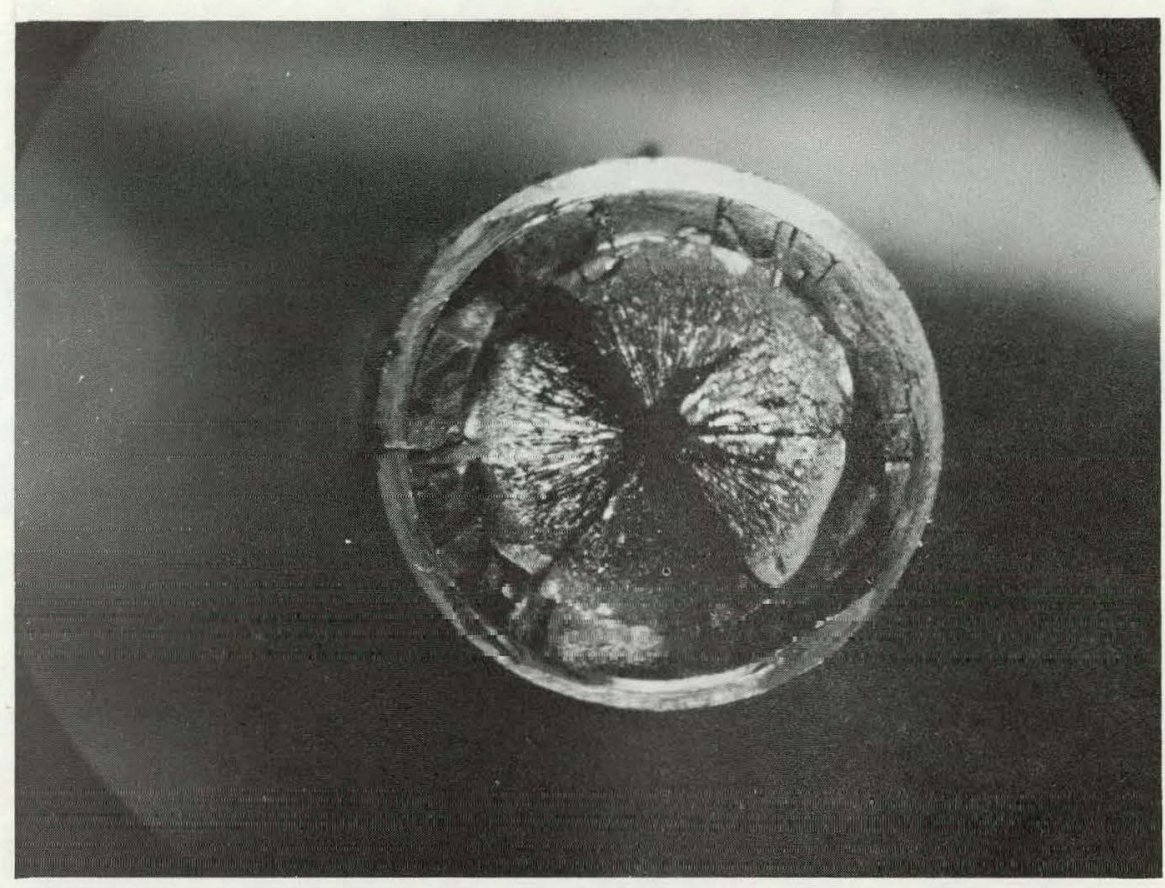

NEG. No. 19129

$3 X$

BOTTOM OF PELLET 35.

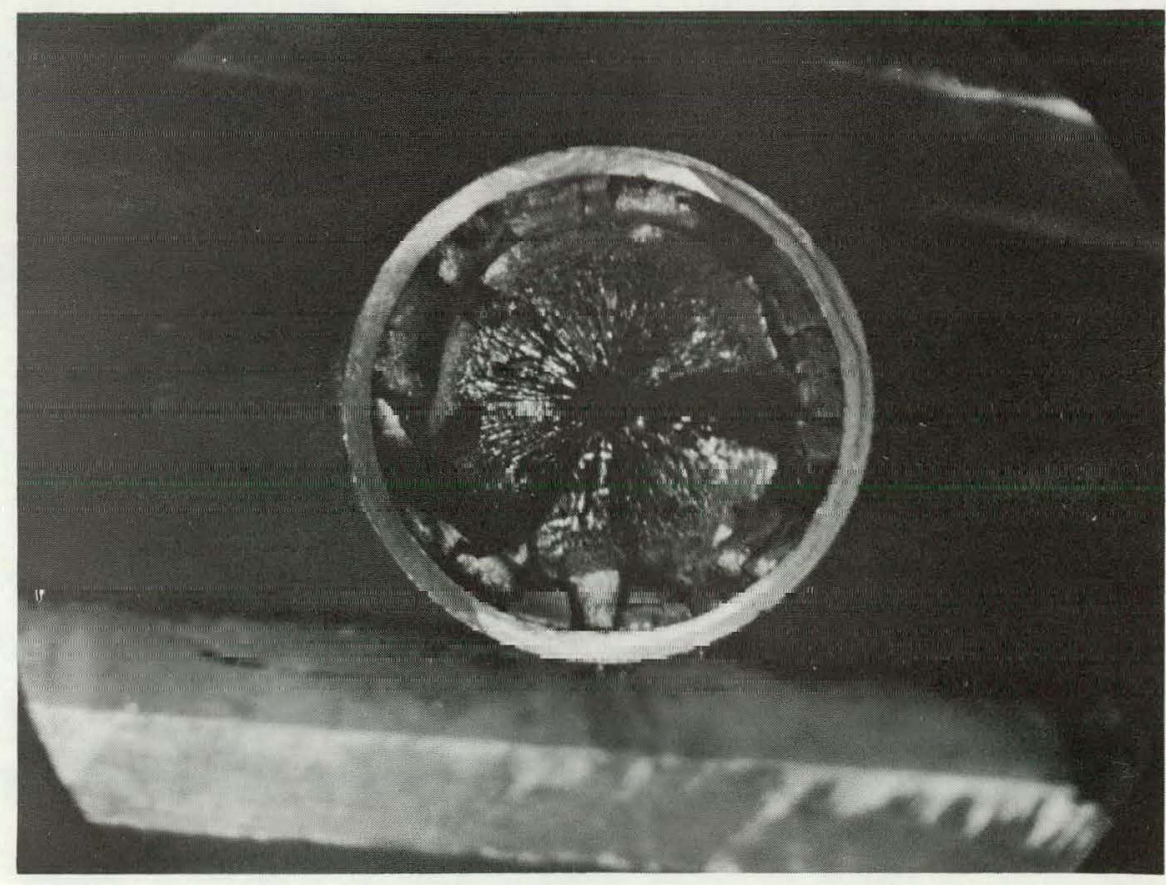

NEG. No. 19128

$3 X$

TOP OF PELLET 34. 


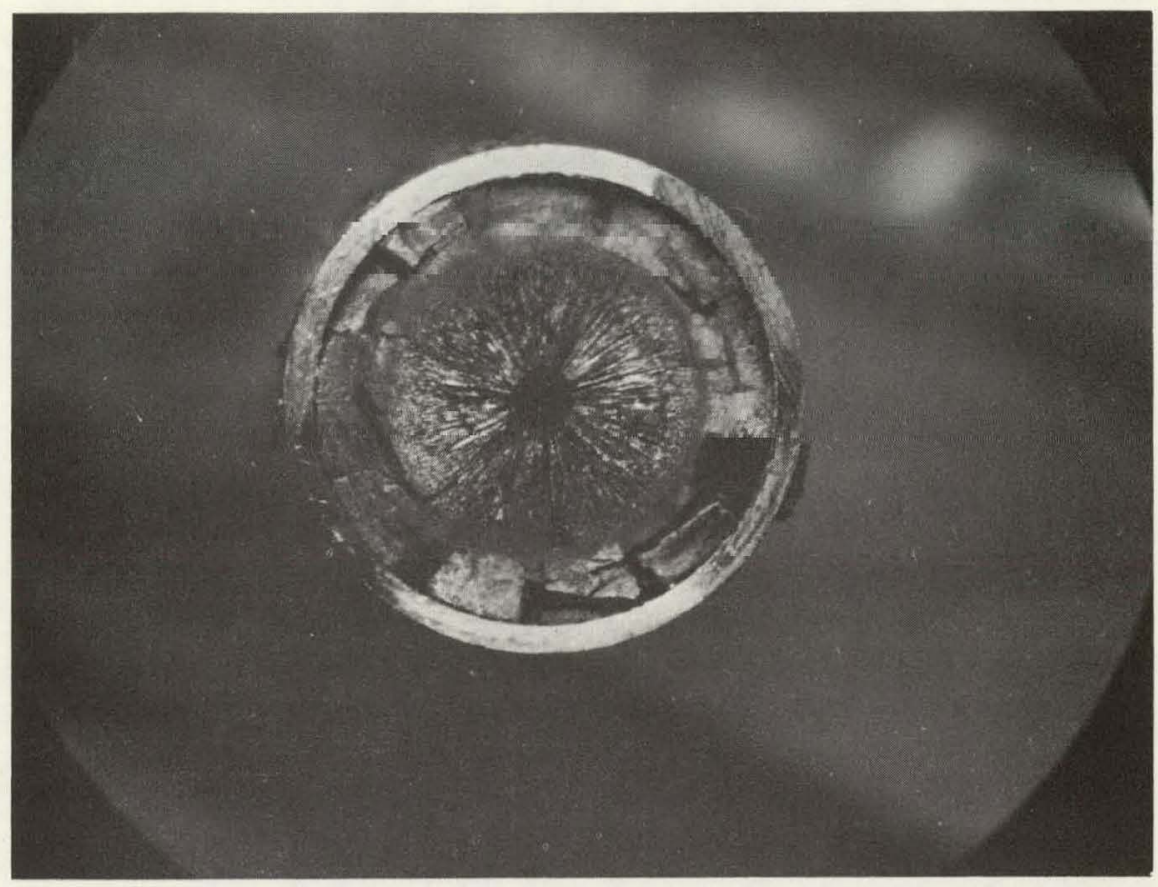

NEG. No. 19133

$3 x$

BOTTOM OF PELLET 36.

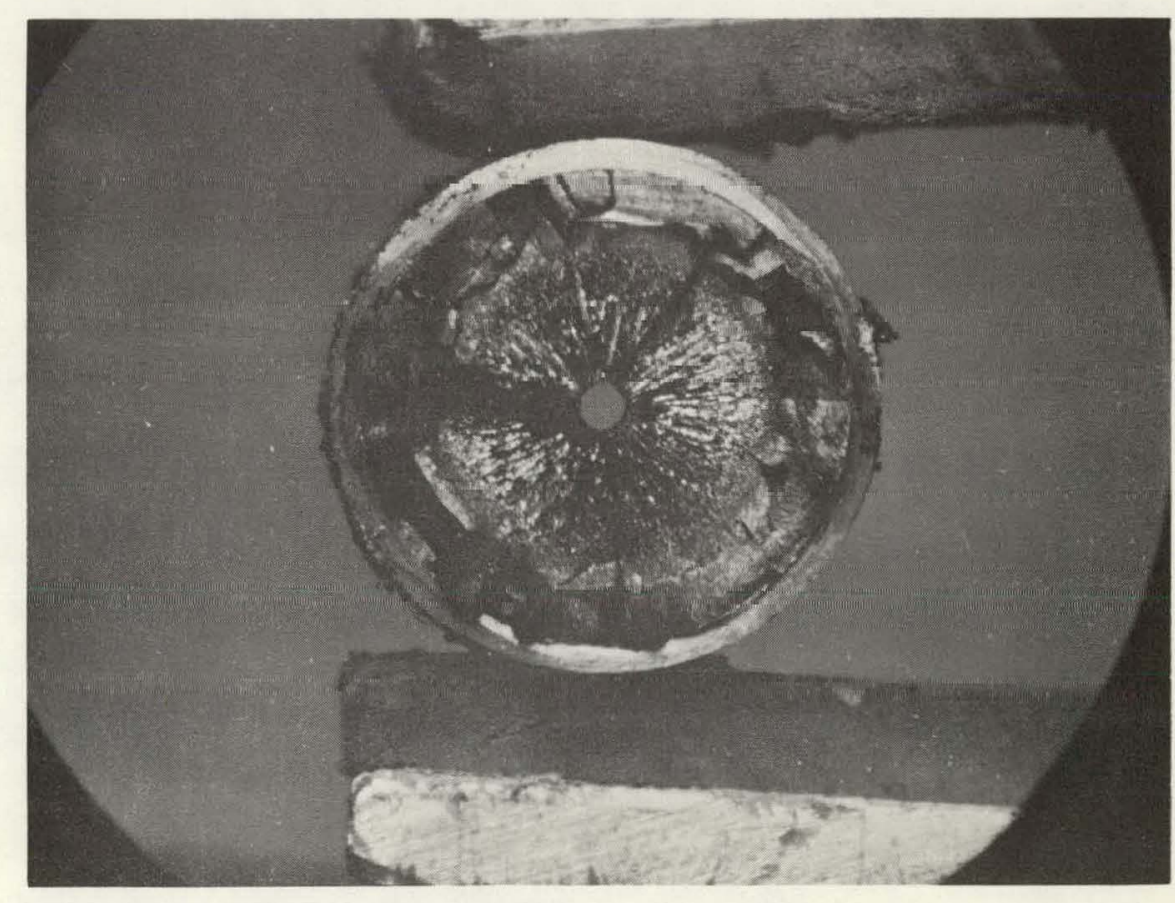

NEG. No. 19132

$3 \mathrm{X}$

TOP OF PELLET 35. 


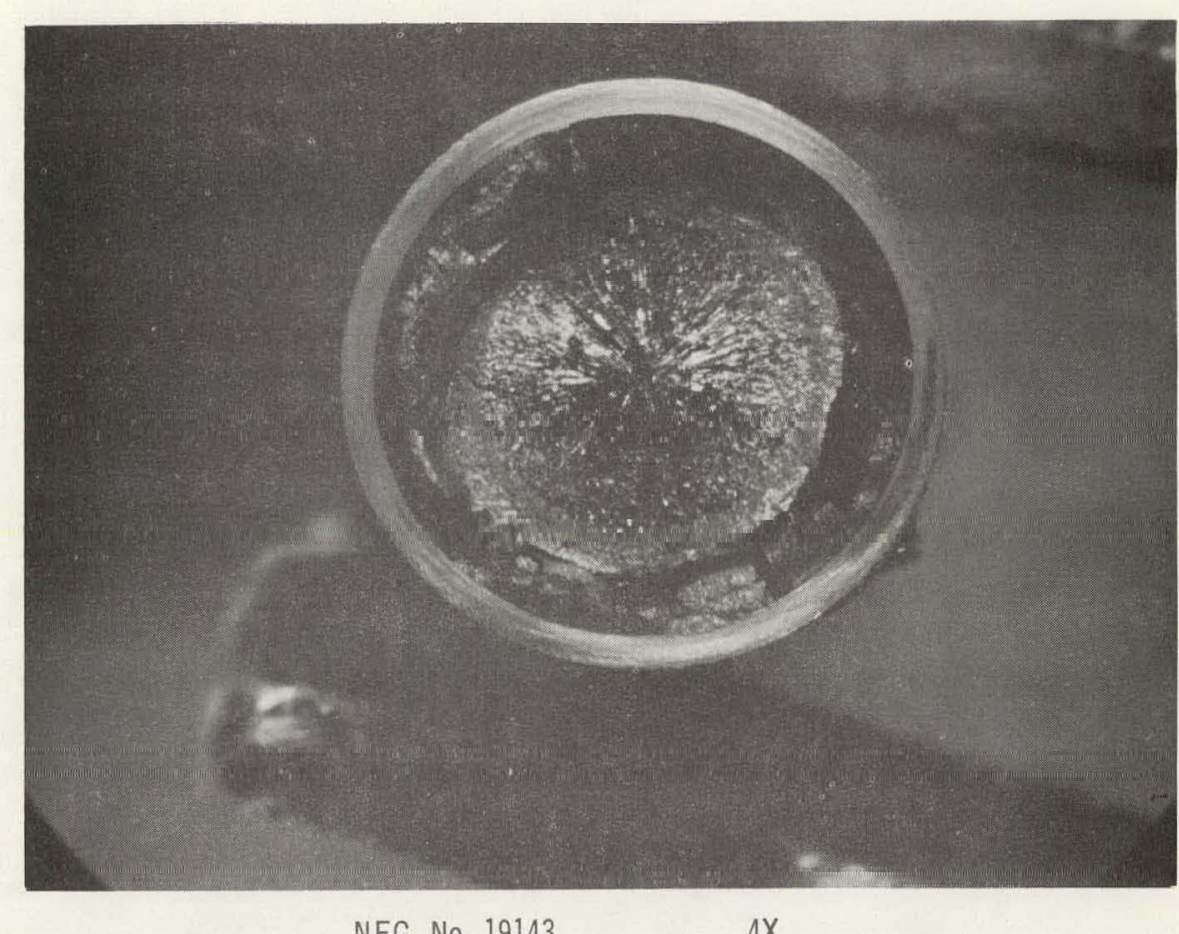

BOTTOM OF PELLET 46.

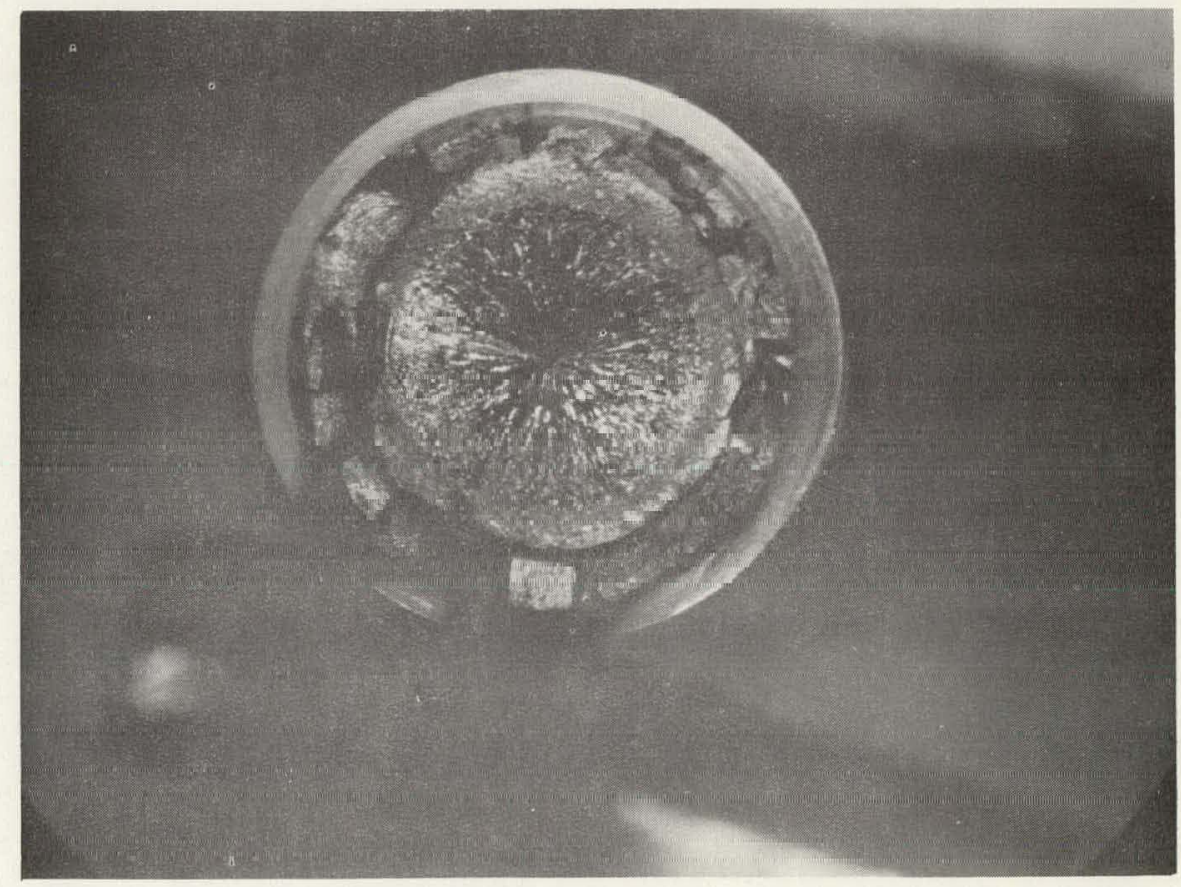

NEG. No, 19144

$4 X$

TOP OF PELLET 45. 


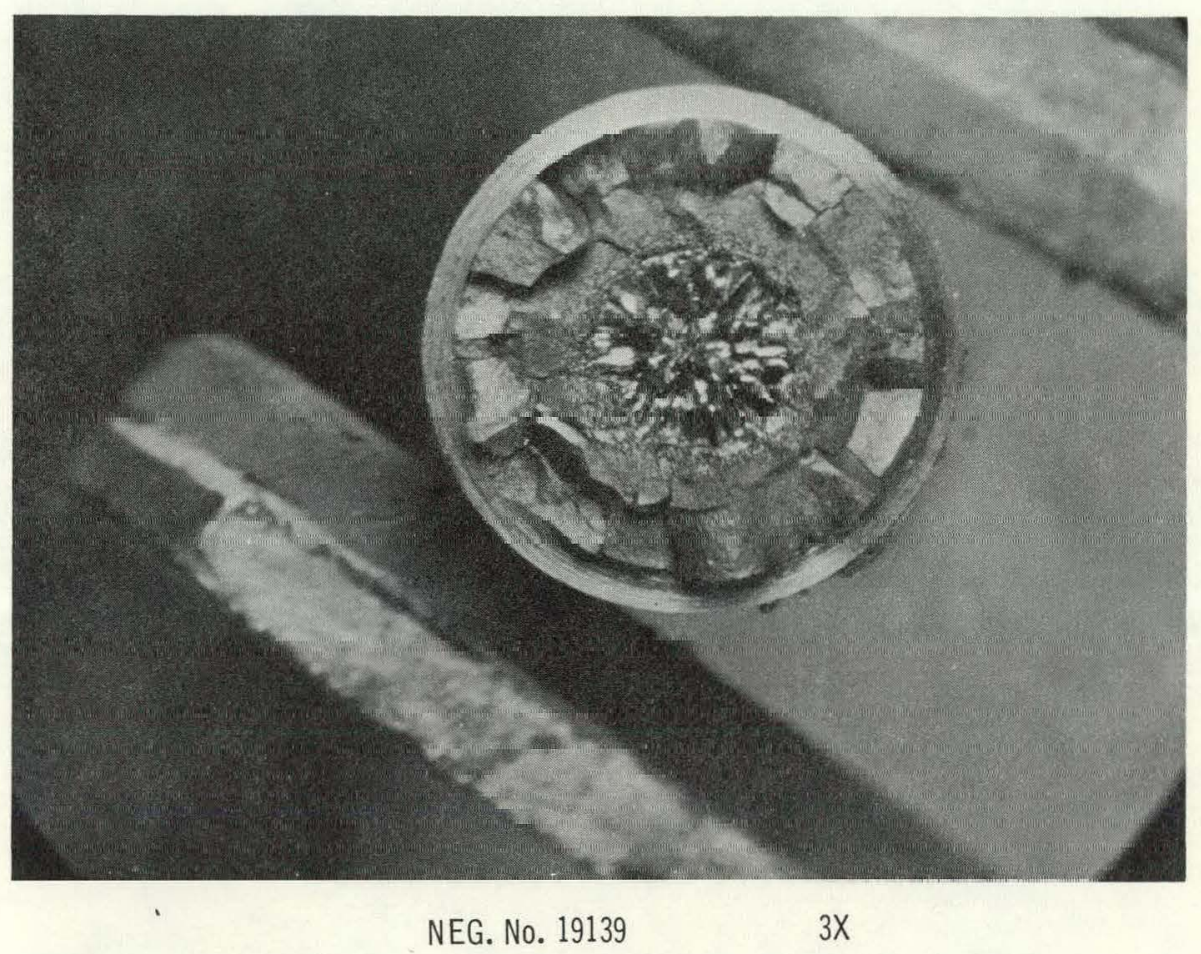

EST. BOTTOM OF PELLET 53.

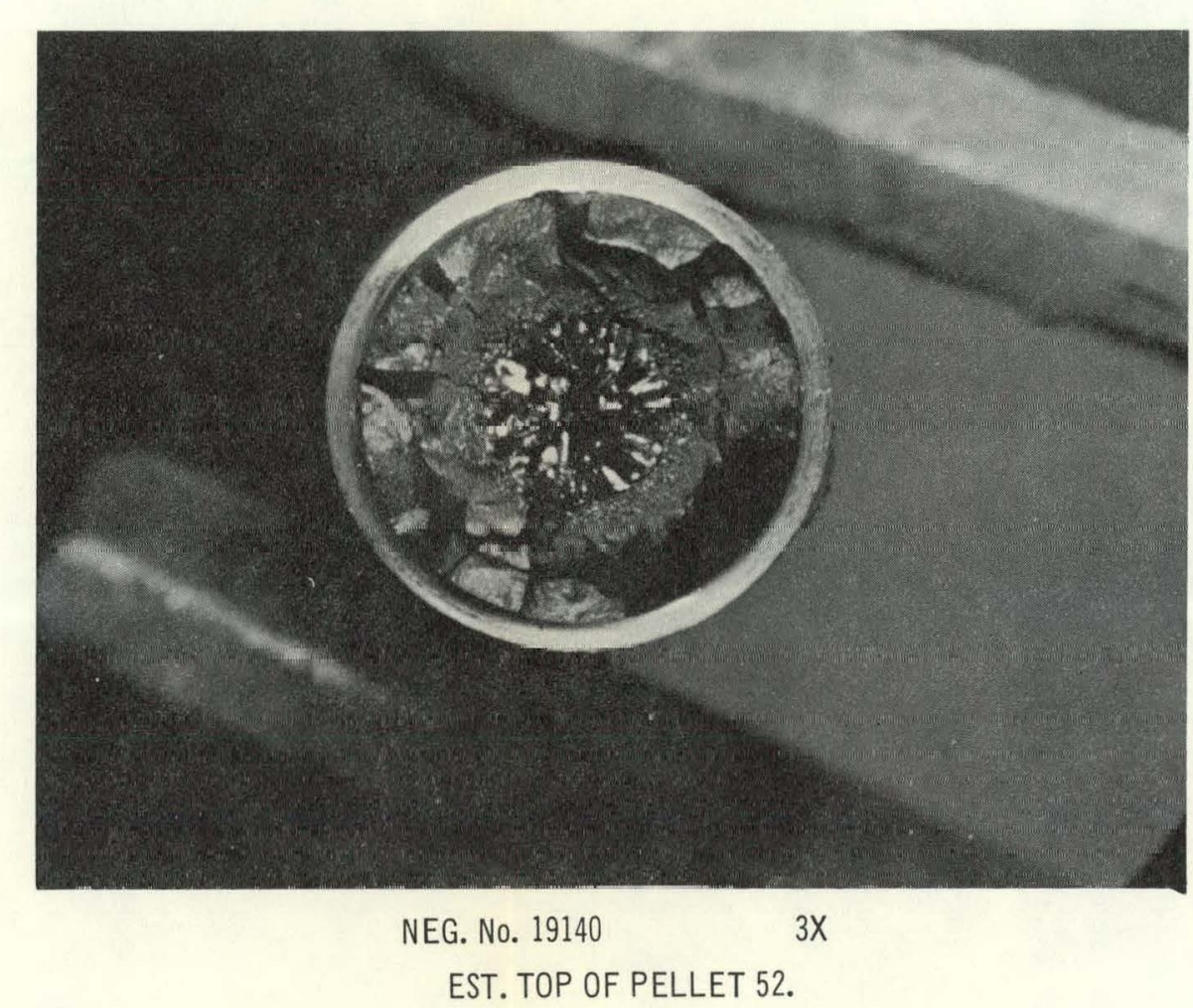

EST. TOP OF PELLET 52.

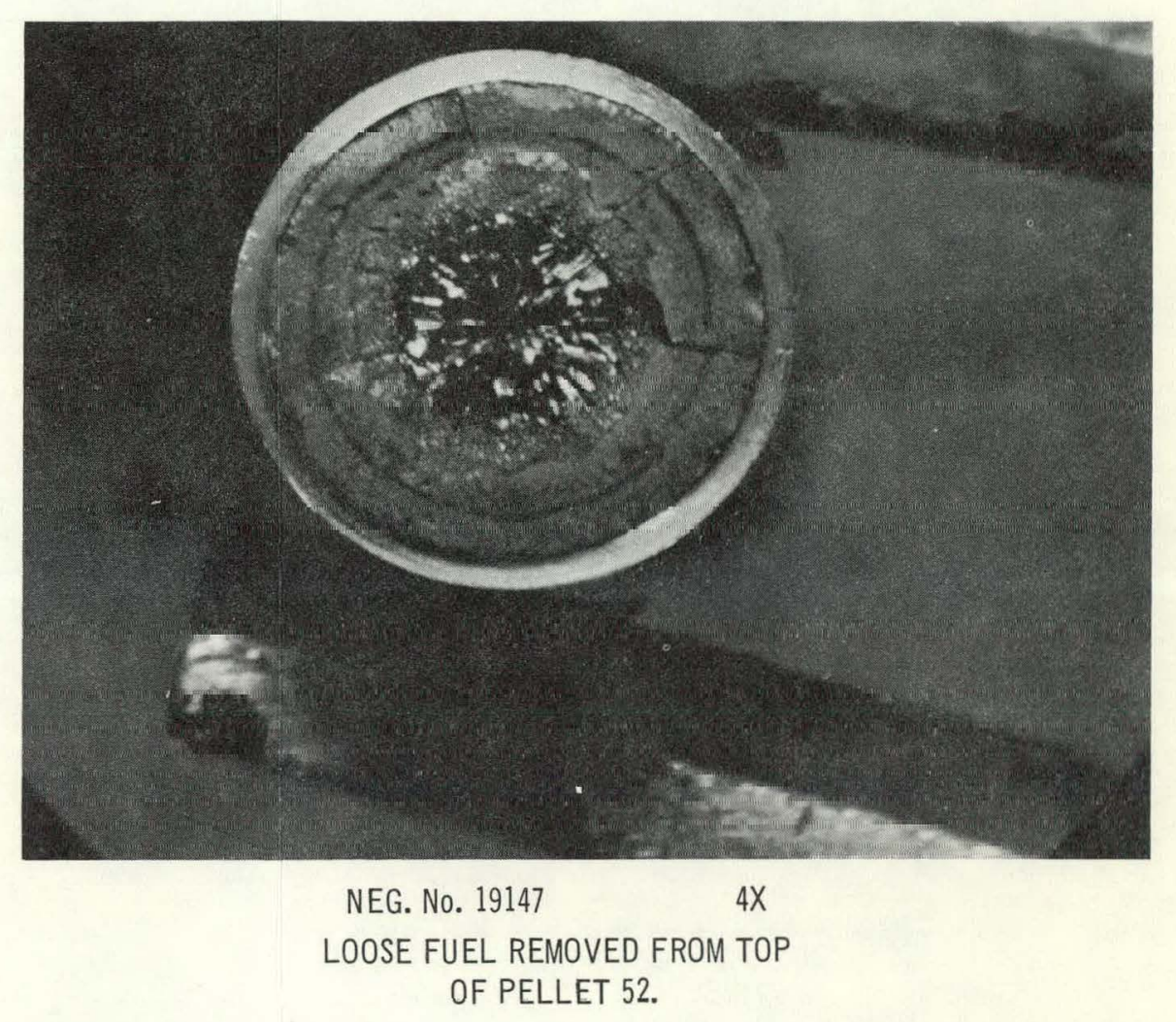


ROD ELEVATION $283 / 8$ Inches

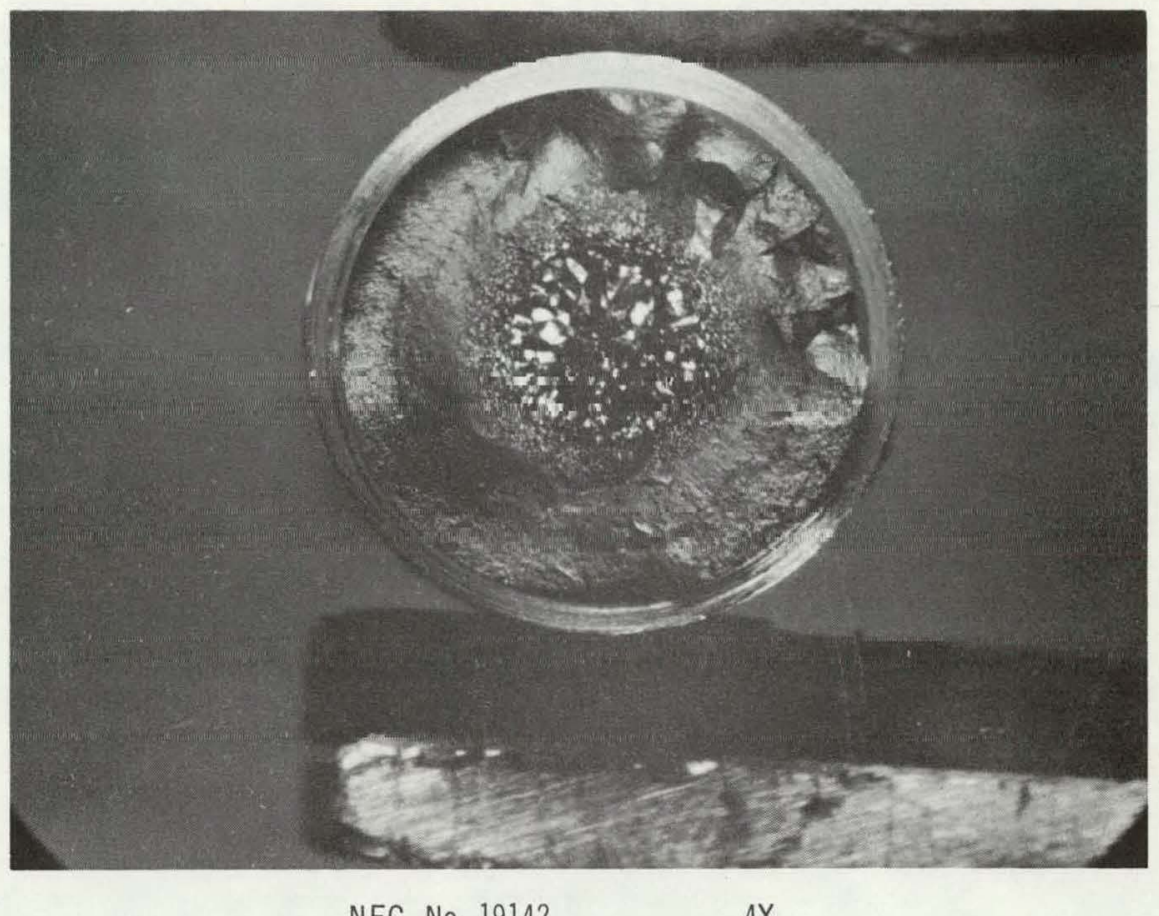

NEG. No. 19142

$4 X$

BOTTOM OF PELLET 54.

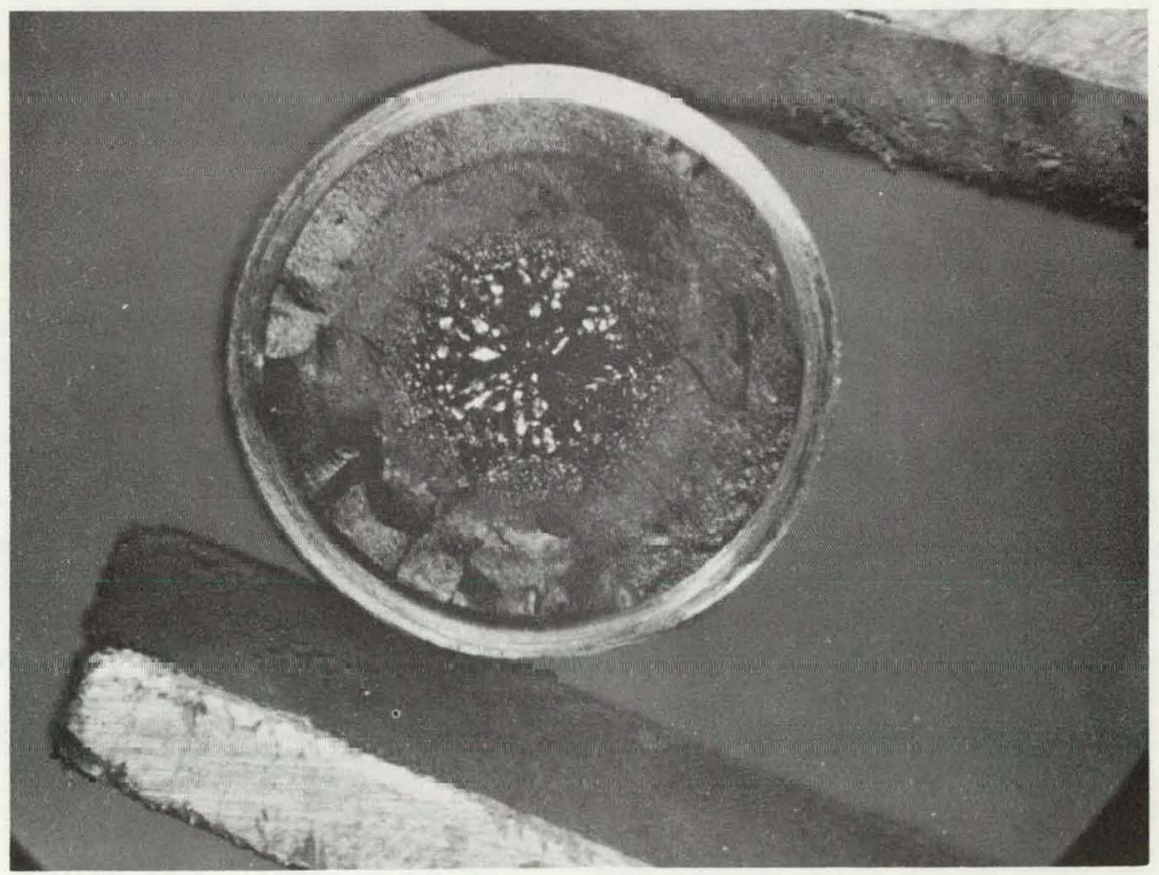

NEG. No. 19141

$4 X$

TOP OF PELLET 53. 
ROD ELEVATION $31 \frac{114}{4}$ Inches

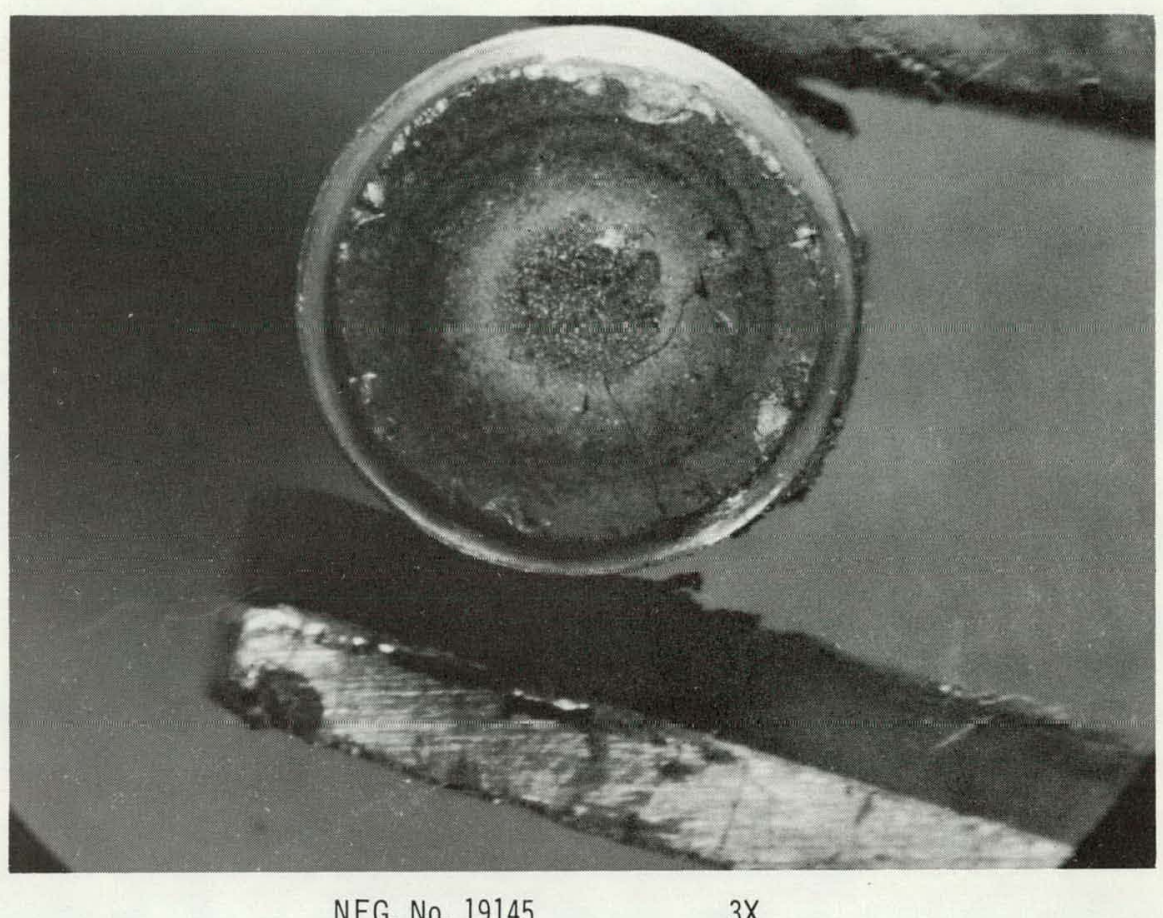

EST. BOTTOM OF PE!LET 59.

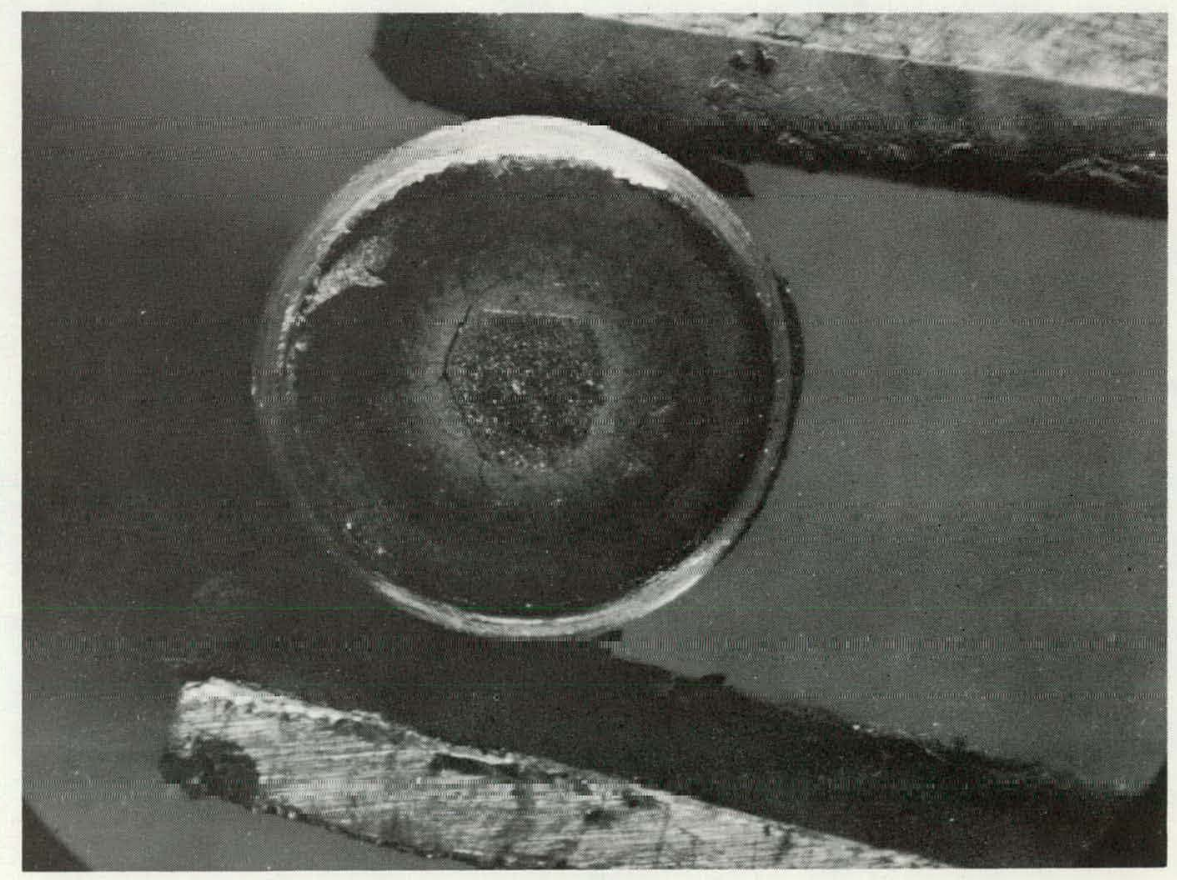

NEG. No. 19146

$3 x$

EST. TOP OF PELLET 58. 


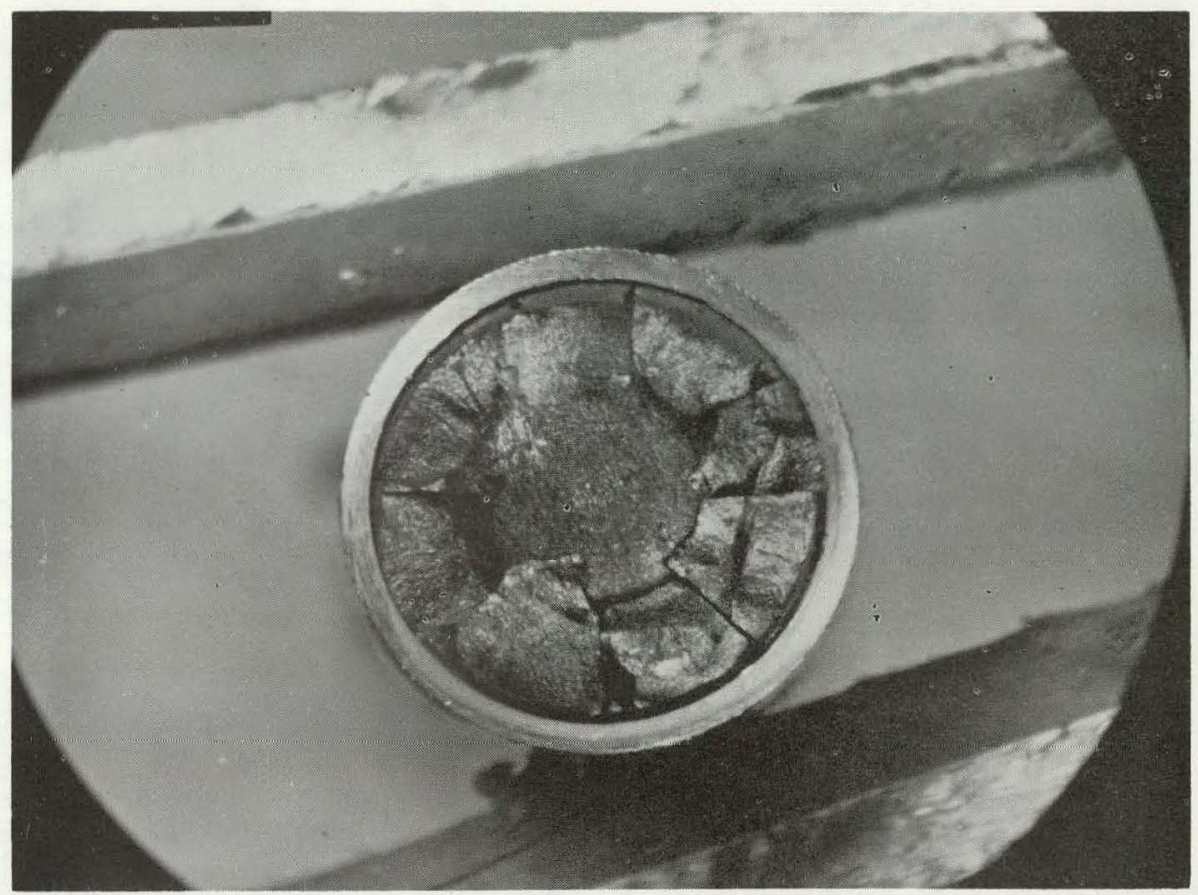

NEG. No. 19134

$3 x$

BOTTOM OF PELLET 60.

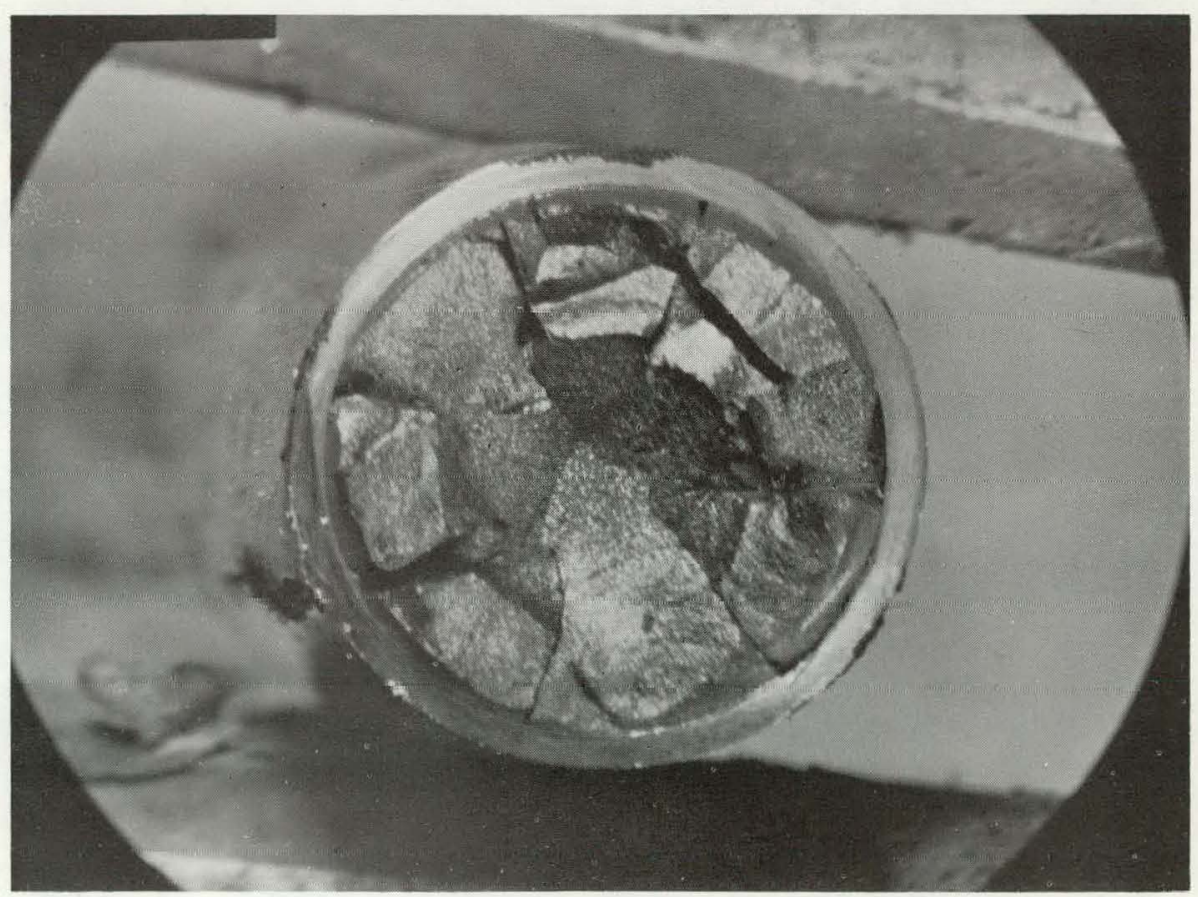

NEG. Nn. 19135

TOP OF PELLET 59. 


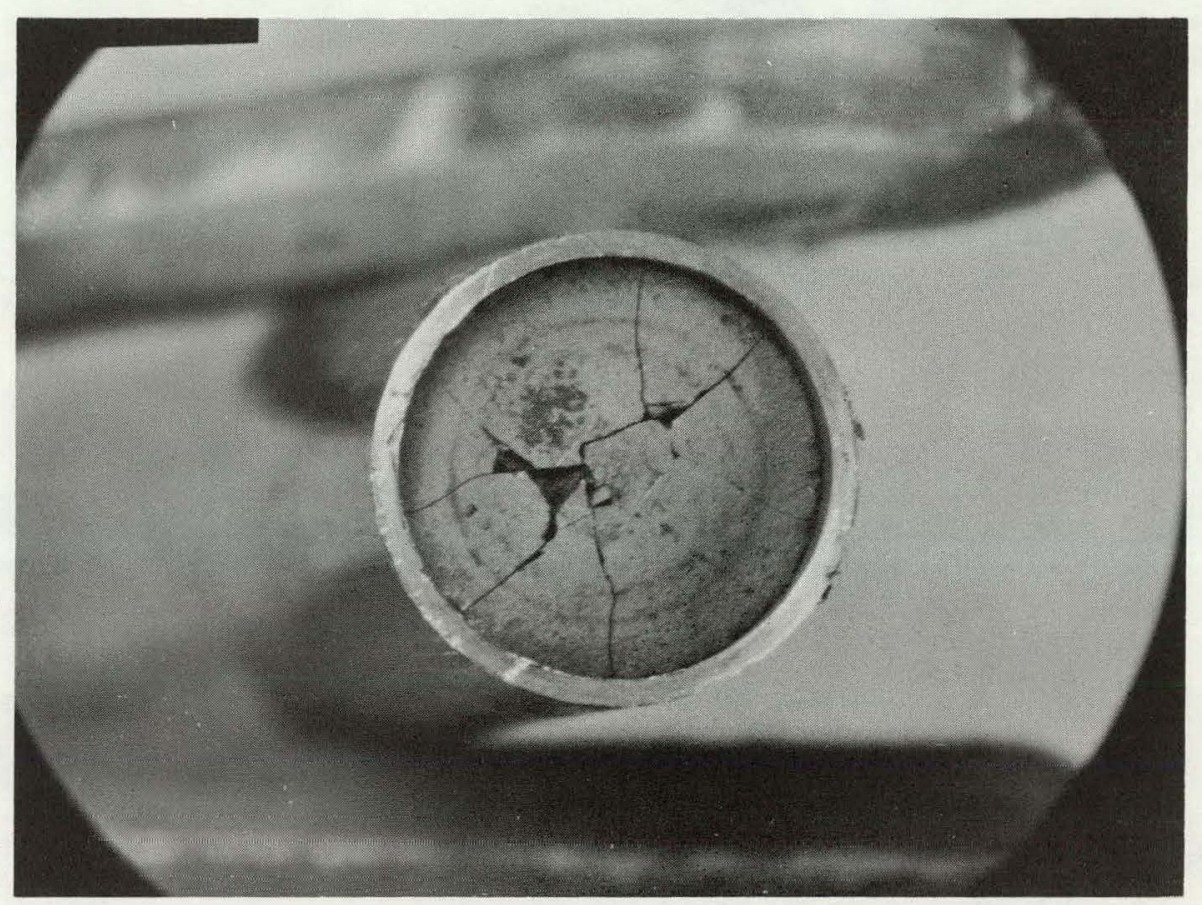

NEG. No. 19138

$3 \mathrm{X}$

TOP OF FUEL COLUMN BELOW Zr-2

DISC, PELLET 65. 


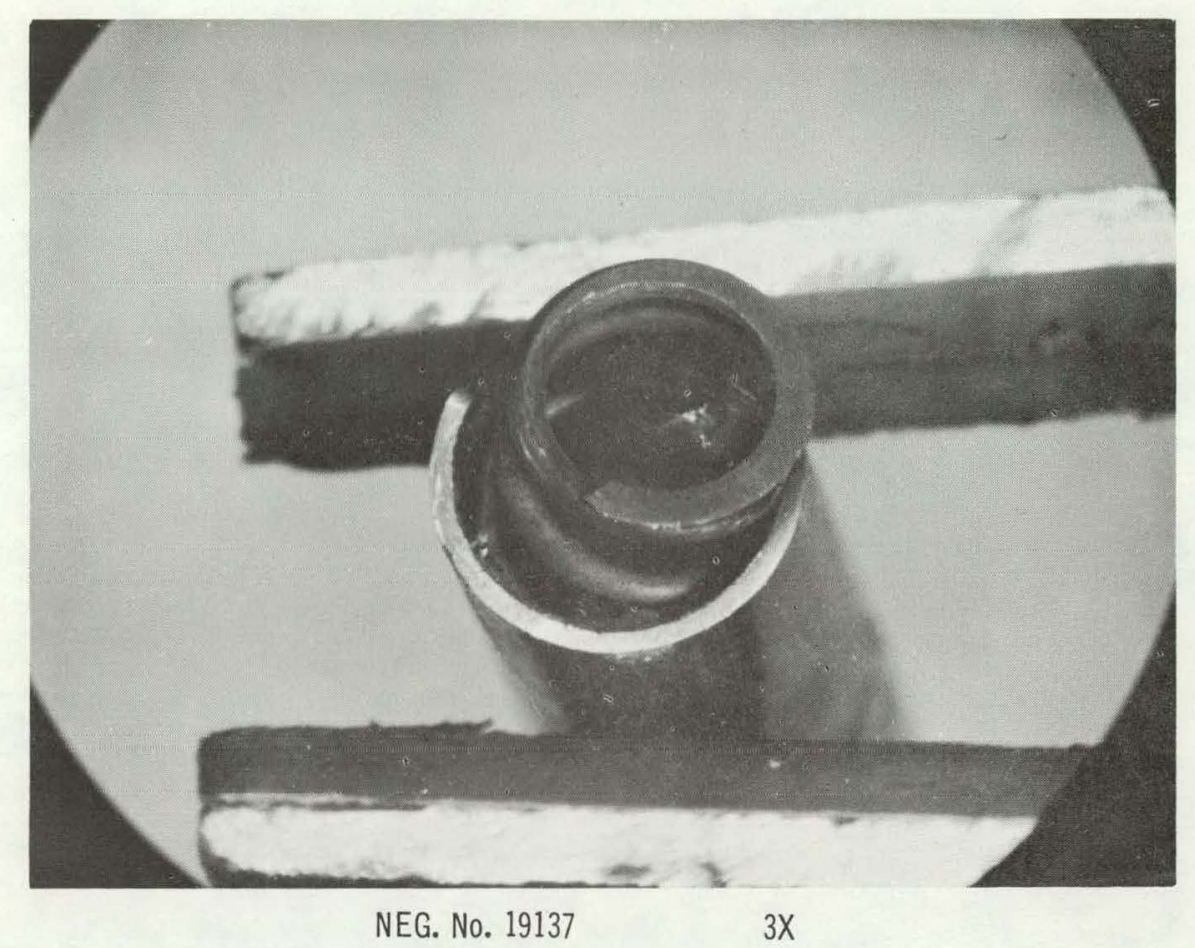

COMPRESSION SPRING IN PLENUM

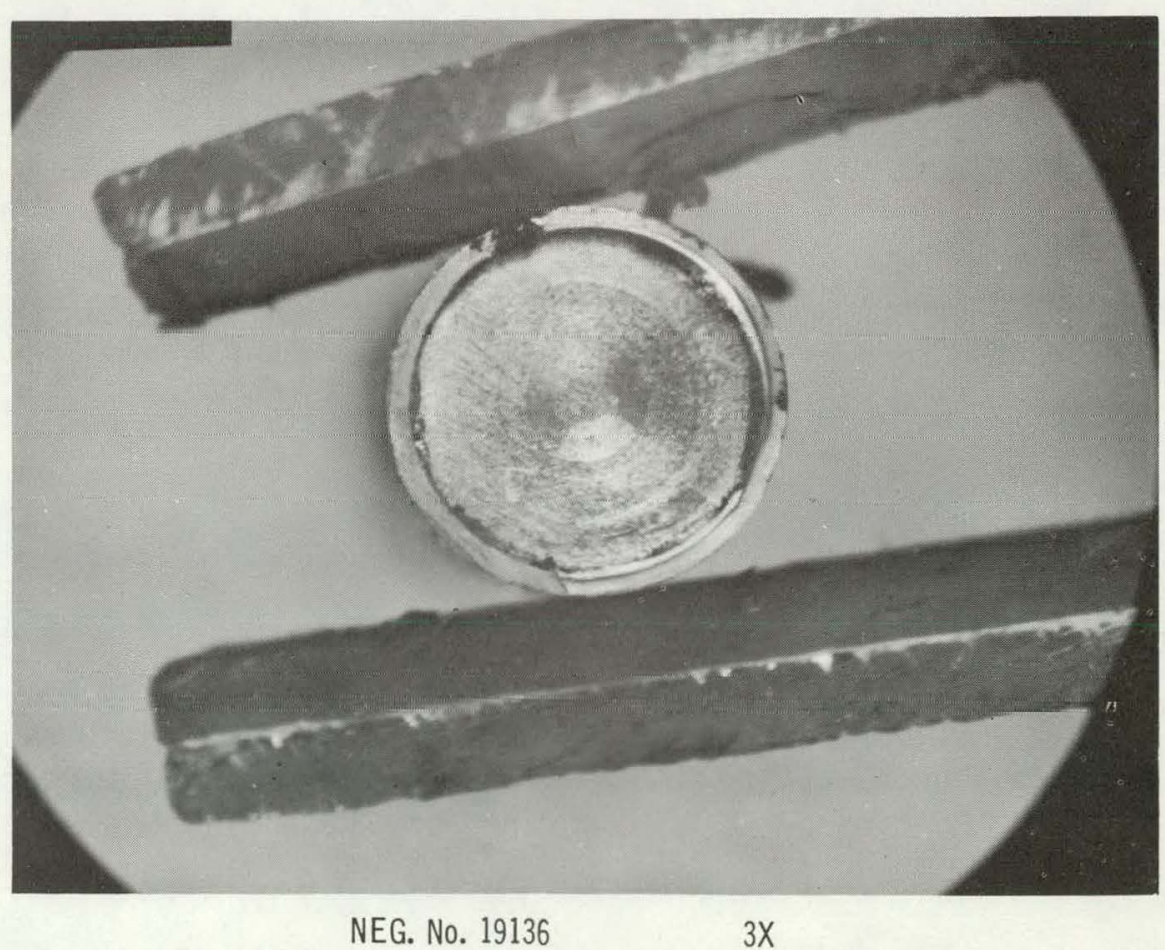

Zr-2 DISC ABOVE FUEL. 


\section{EPT-6 ROD-D}

\section{METALLOGRAPHIC SECTIONS}

ALL SECTIONS ARE “AS POLISHED" UNLESS MARKED "ETCHED." ALL LIGHTING USED IS "BRIGHT FIELD" UNLESS MARKED "POLARIZED LIGHT."

NUMBERS AFTER AUTORADIOGRAPH CAPTIONS INDICATE NUMBER OF DAYS AFTER END OF IRRADIATION. 
TABLE 8

MAIN METALLOGRAPHIC SECTIONS ROD 6-D

When Section was of Interest

Section was Made to Show

Section Number
Start-Up (4/24/62)

PHF* $\quad$ MS**

8561

8577

MS**

8576

Shut-Down

$(5 / 14 / 62)$

Pages in Photo Collection

Axial Distance from Bottom of Rod, in.

8

$81 / 4-91 / 4$

$91 / 4-10 \quad 1 / 4 \quad 181 / 4$

Control Rod Bank Position, in.

19.3

19.3

19. 3

28.1

Post Irradiation Diameter, in. :

Fuel

0.544

0.606

0.589

0.574

0.564

Fractional Diameter Increase at Section:

1.072

1.043

1.019

Rod Average Heat Flux at Time of Interest, Btu/h-ft ${ }^{2}$ 453,000

453,000

453,000

483,000

Axial Peaking Factor at Section

1.57

1.59

1.62

1.32

Peak Heat Flux at Section

$$
\text { Life, Btu/h-ft }{ }^{2}
$$

711,000

720,000

734,000

638,000

Estimated Heat Flux after

$$
\text { Swelling, Btu/h-ft }{ }^{2}
$$

746,000

$1,001,000$

751,000

763,000

End of Life Heat Flux,

$$
\mathrm{Btu} / \mathrm{h}-\mathrm{ft}^{2}
$$

406,000

425,000

448,000

596,000

Normalized Radius for Melting

$(\alpha \mathrm{M})$

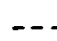

$--$

0.133

Flux Depression Factor

Before Swelling:

$$
\begin{aligned}
& { }_{\mathrm{T}}\left(\mathrm{h}_{\text {gap }}=2000\right),{ }^{\circ} \mathrm{F} \\
& \int_{\mathrm{T}_{\mathrm{S}}}^{\mathrm{T}} \mathrm{kdt} \text {, watts } / \mathrm{cm} \\
& \int_{0}^{\mathrm{T}} \mathrm{mdt} \text {, watts } / \mathrm{cm} \\
& \text { * Peak Heat Flux Zone } \\
& \text { ** Maximum Bwelling Züe } \\
& \text { ***Maximum Burnup Zone }
\end{aligned}
$$

0.24

964

65.0

95.4 
TABLE 8. (Continued)

Start-Up (4/24/62)

After Swelling:

$\int_{0}^{T_{m}} k d t$, watts $/ c m$

$---$

95.4

Based on Autoradiography

Normalized Radius for Melting,

$-\therefore$

0.496

$--$

0.410 $(\alpha \mathrm{M})$

Flux Depression Factor

0.185

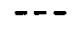

$-\cdot-$

0.205

Before Swelling: $\mathrm{T}_{\mathrm{S}},{ }^{\circ} \mathrm{F}$

1056

1070

1075

1007

$\int_{T_{s}}^{T_{m}} k d t$, watts $/ c m$

59.5

$--$

59.4

$\int_{0}^{T_{m}} k d t$, watts $/ \mathrm{cm}$

91.7

$--$

$---$

90.7

After Swelling:

$$
\begin{aligned}
& { }^{T_{s^{\prime}}}{ }^{\circ} \mathrm{F} \\
& \int_{\mathrm{T}_{\mathrm{s}}{ }^{\mathrm{T}} \mathrm{kdt}, \text { watts } / \mathrm{cm}} \\
& \int_{0}^{\mathrm{T}_{\mathrm{m}}} \mathrm{kdt}, \text { watts } / \mathrm{cm}
\end{aligned}
$$$$
1108
$$$$
--
$$$$
64.0
$$

97.3

$--$

91.1 


\title{
EPT-6 ROD-D
}

\author{
PEAK HEAT FLUX ZONE
}

ROD ELEVATION 8 Inches FROM BOTTOM 
GEAP-5100A

\section{ROD ELEVATION 8 Inches}

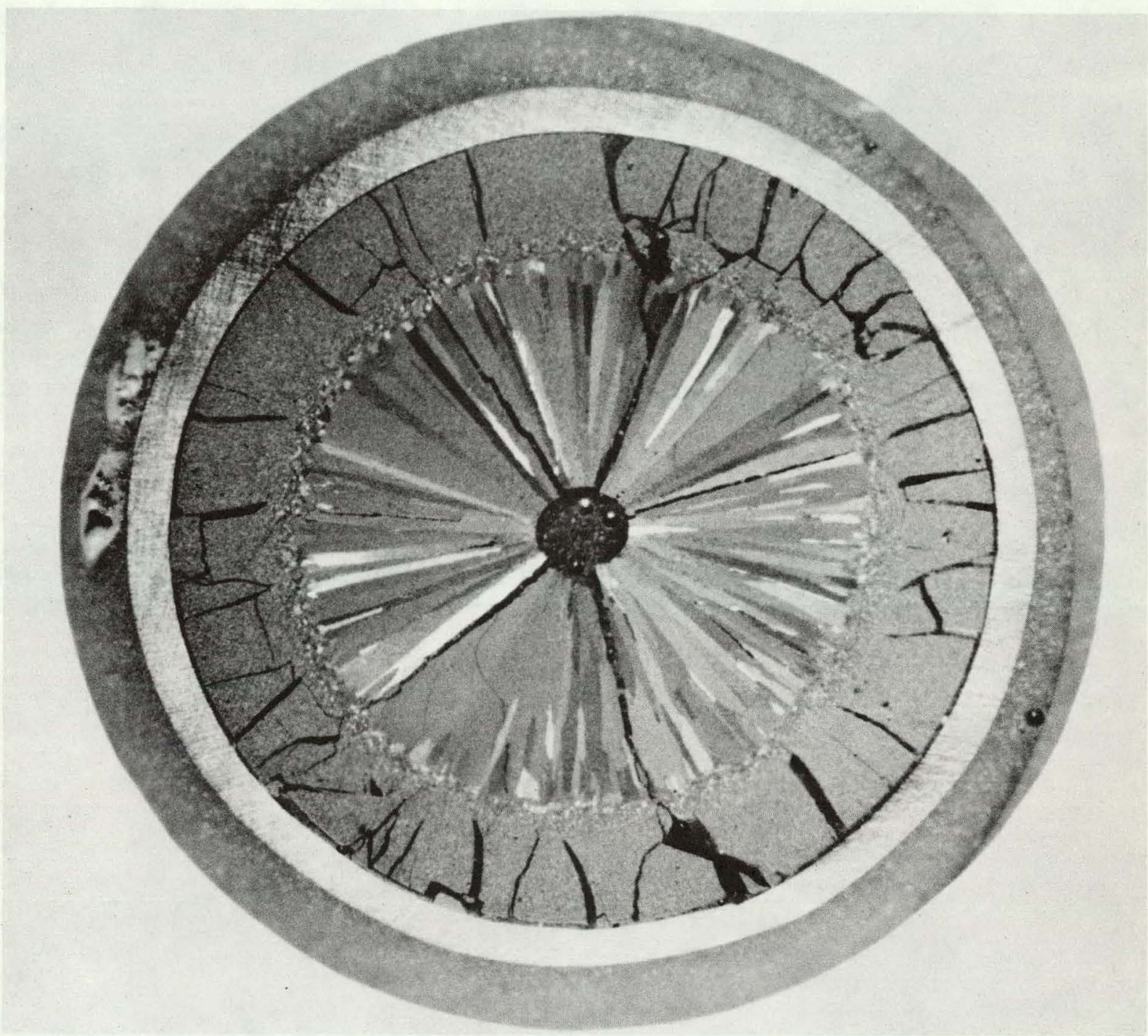

NEG. No. 8561-01 (OFF $600 \mathrm{SiC}$ ) 10X

PHOTOMACROGRAPH OF TRANSVERSE FUEL ROD SECTION AT PEAK HEAT FLUX ZONE BETWEEN PELLETS 15 \& 16. 


\section{ROD ELEVATION 8 Inches}

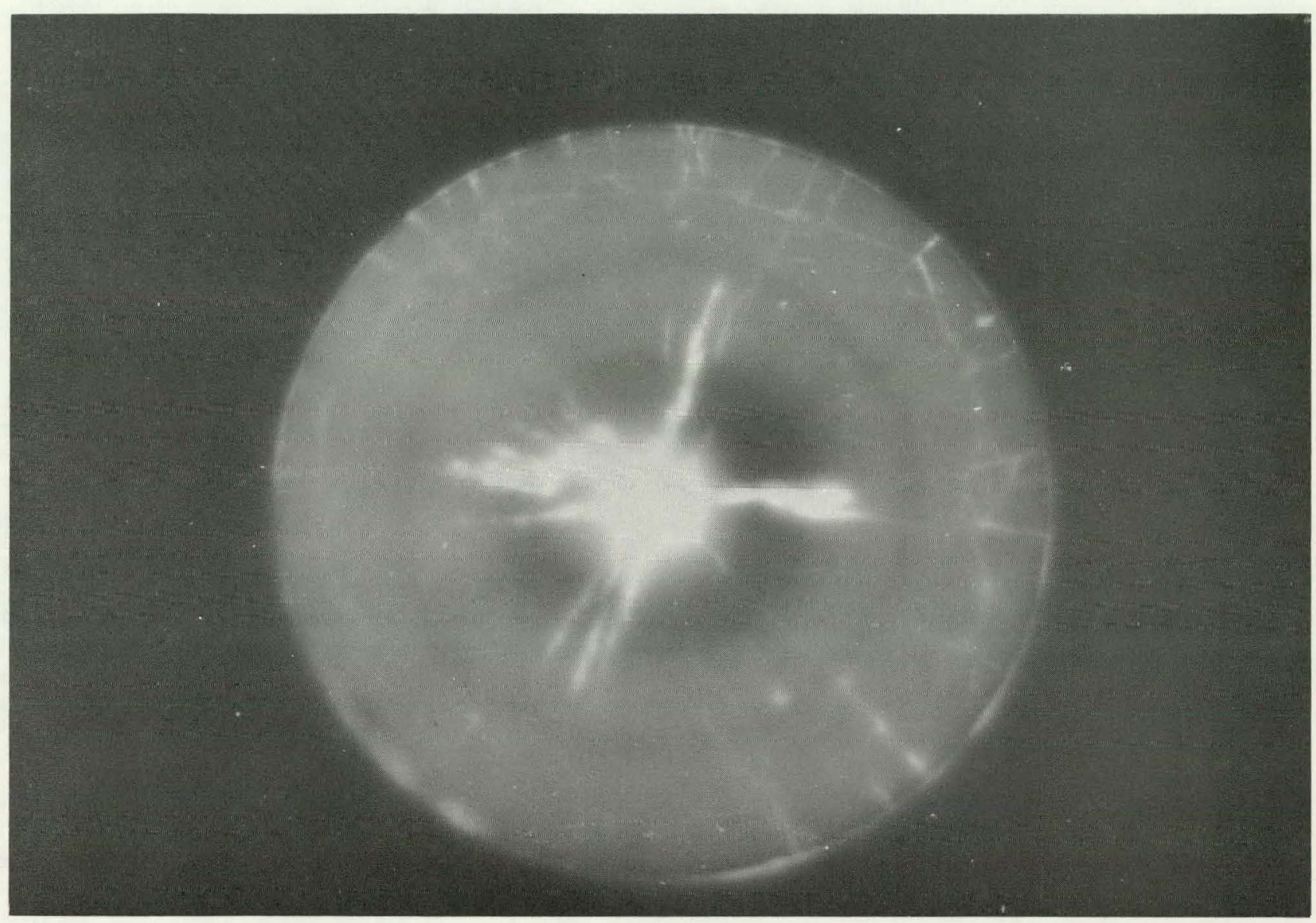

NEG. No. 8561-00

10X

$\beta \cdot \boldsymbol{\gamma}$ AUTORADIOGRAPH OF SAME SECTION

AS IN NEG. No. 8561-01 



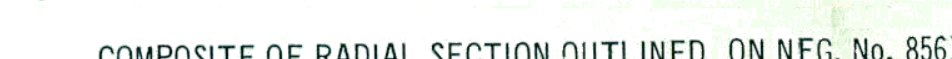




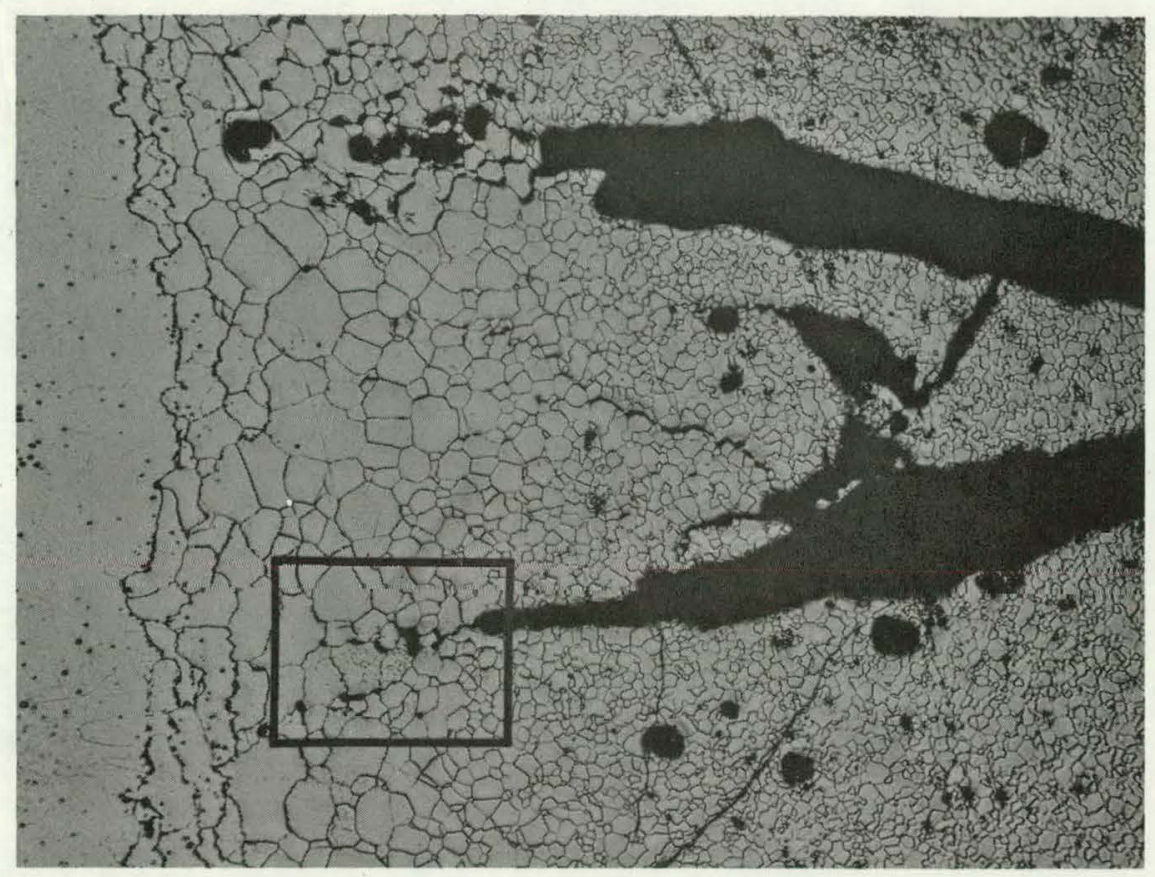

NEG. No. 8561-24 (ETCHED) 100X

TERMINUS OF A RADIAL CRACK IN THE OUTER BAND OF FUEL.

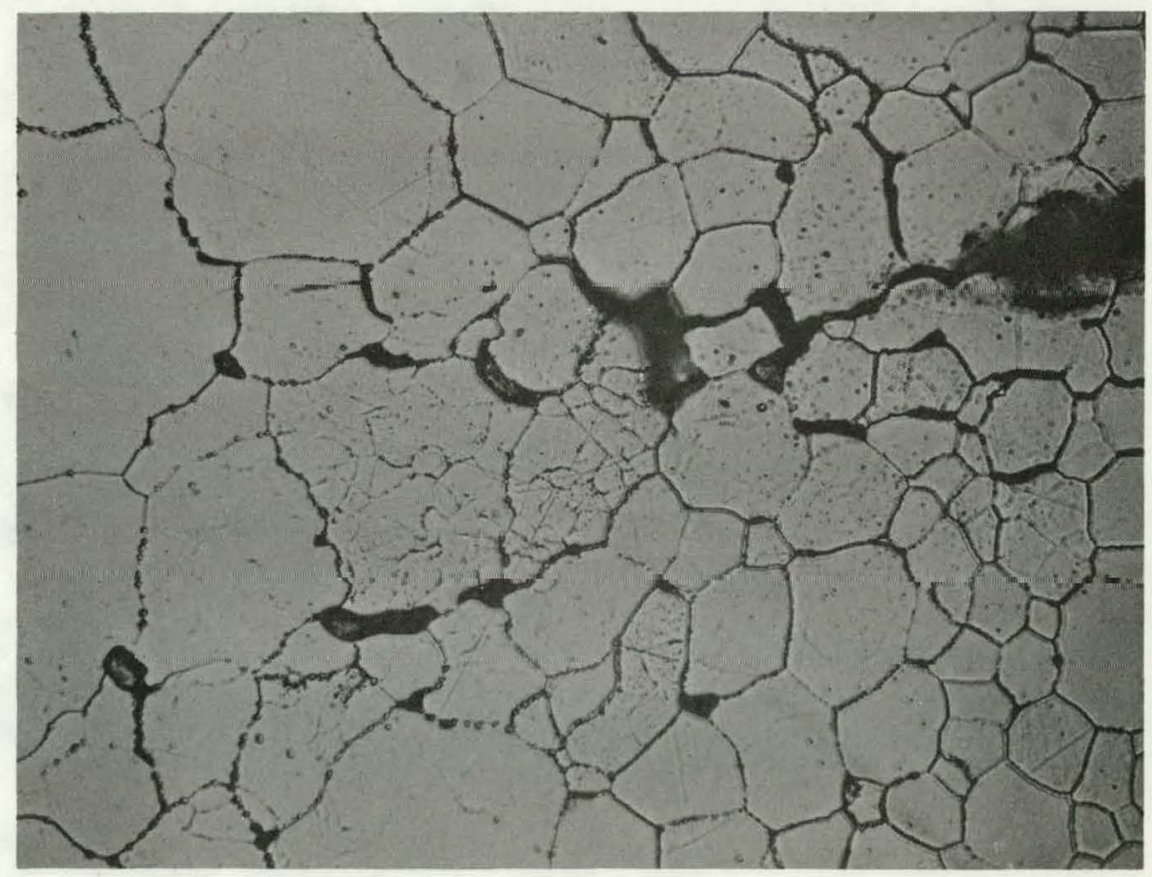

NEG. No. 8561-25 (ETCHED) 100X

ENLARGEMENT OF CRACK TERMINUS. 


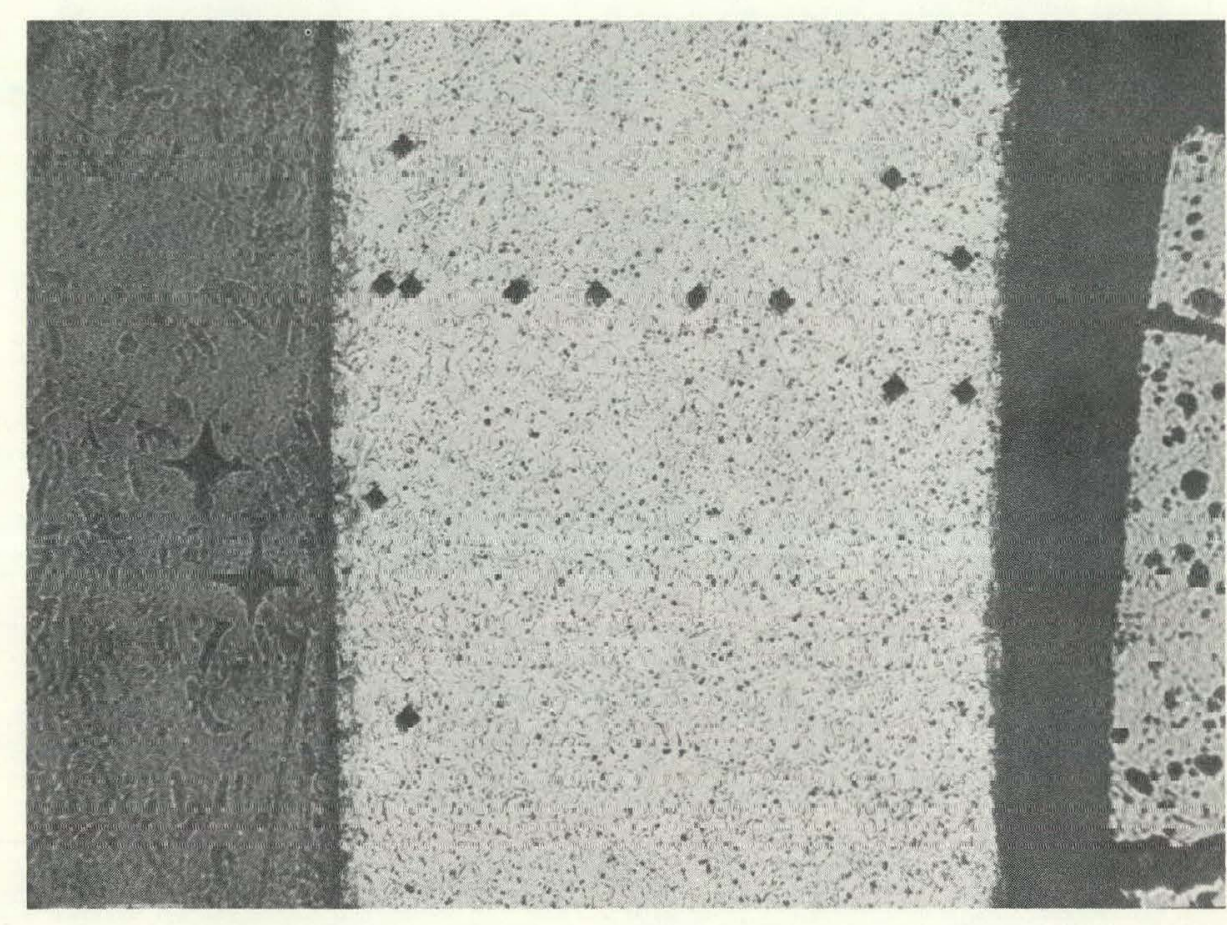

NEG. No. 8561-23

$100 x$

REPRESENTATIVE SECTION OF THE CLADDING NEAR THE BULGE SHOWING HARDNESS INDENTS

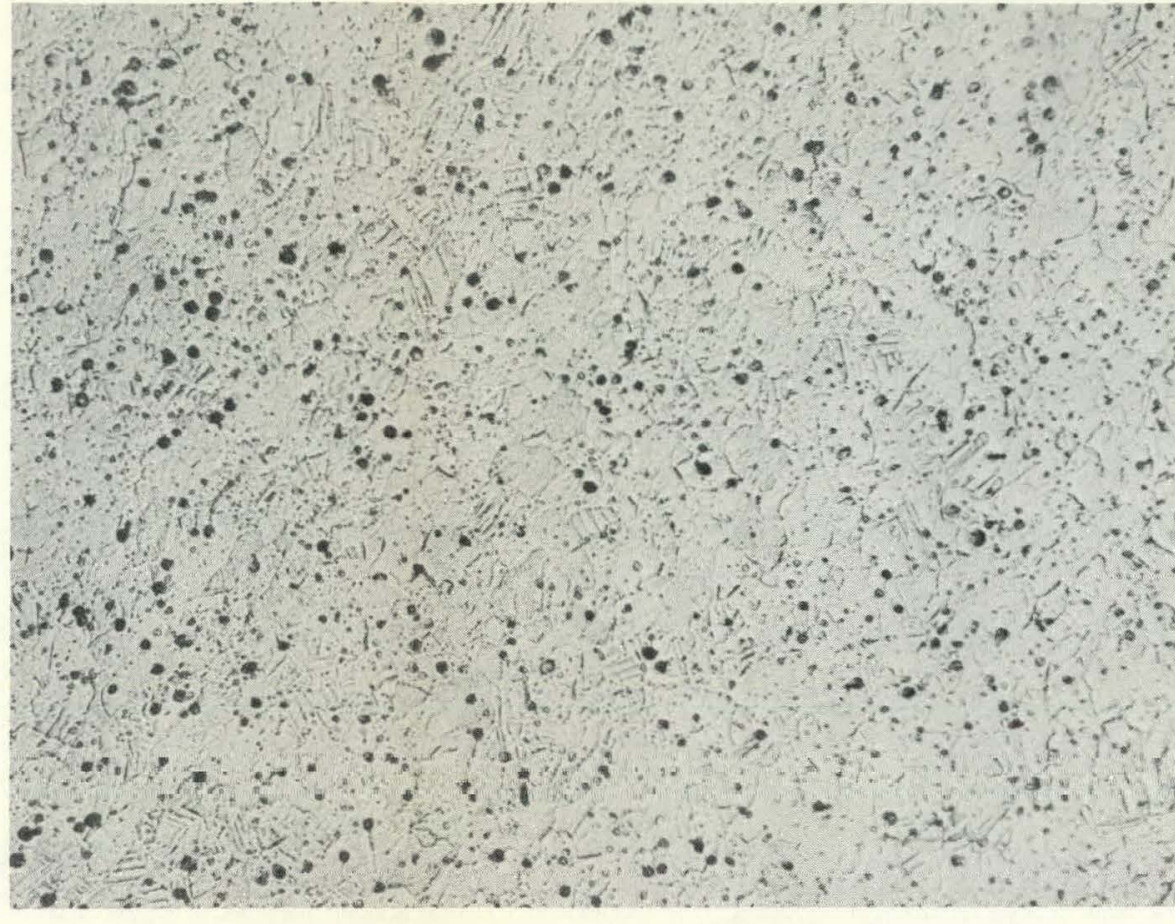

NEG. No. 8561-22 250X
A REPRESENTATIVE SECTION OF THEICENTRAL REGION OF THE CLADDING SHOWING TWINNING

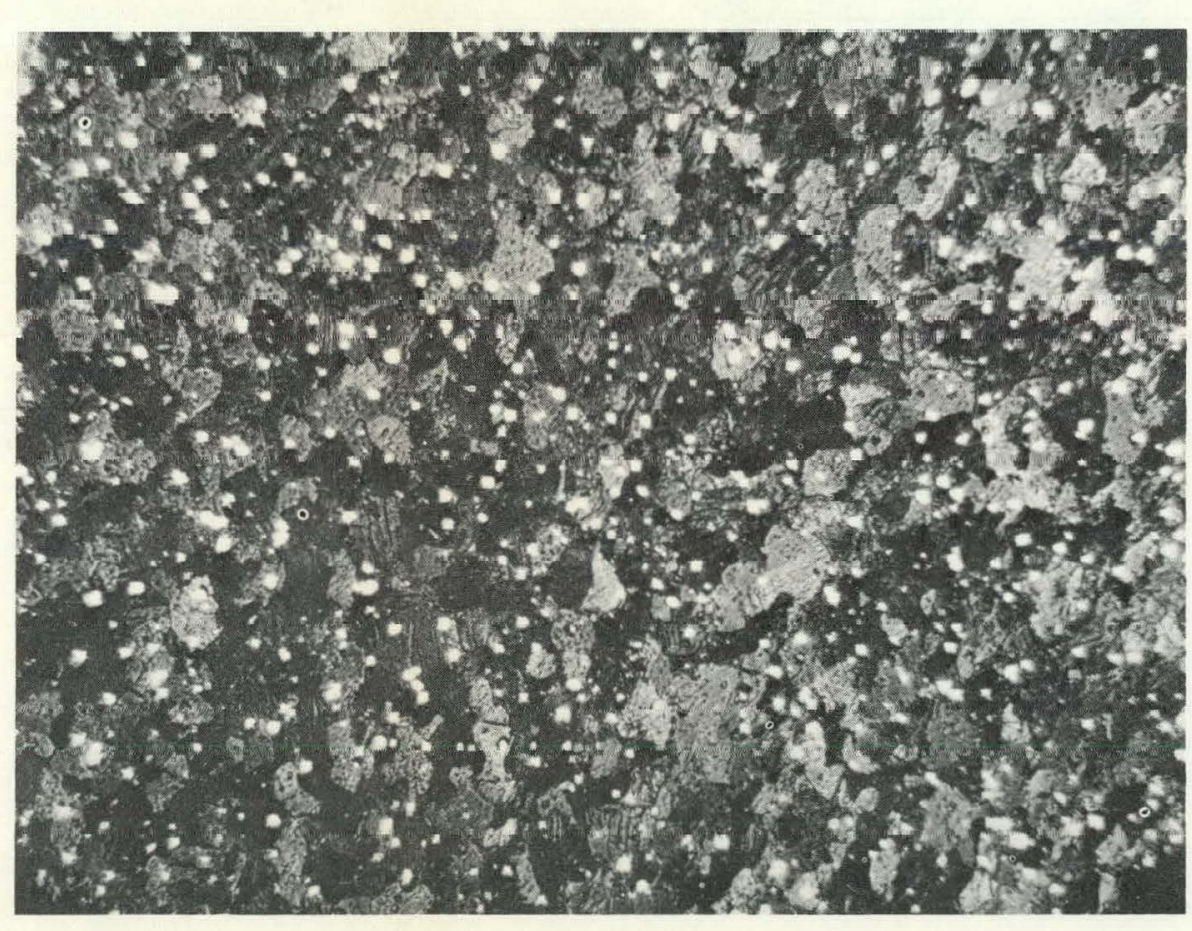

NEG. No. 8561-21

$250 \mathrm{X}$

SAME AREA AS SHOWN IN NEG No. 8561-22 USING POLARIZED IGHT TO SHOW GRAIN STRUCTURE.

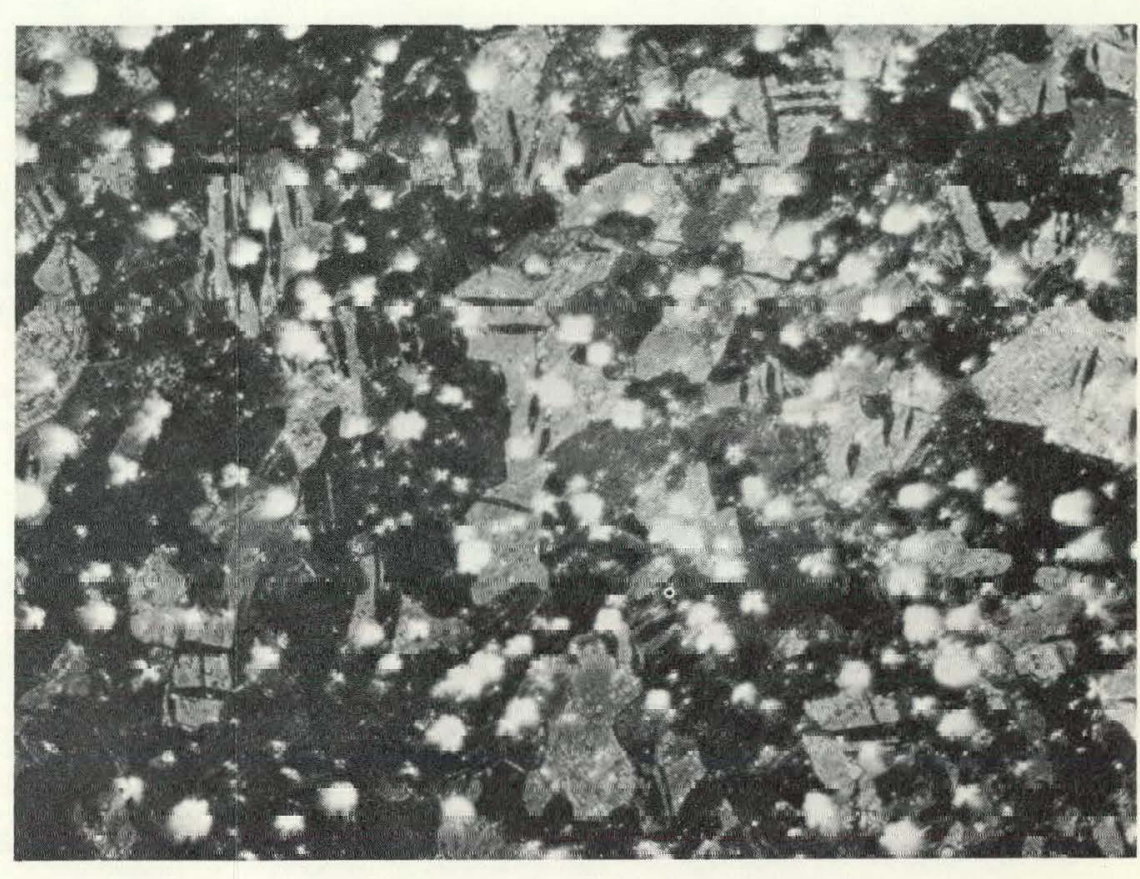

NEG. No. 8561-20 $500 x$ ENLARGEMENT OF SAME AREA (AS NEG No. 8561-21). 
TABLE 9.

\section{MICROHARDNESS DATA SHEET}

EPT 6-D

Bulge In Clad at Peak Heat Flux

$0.1 \mathrm{~kg}$ Load

Test No.

1

2

3

4

5

6

7

8

9

10

11
Aver. Dia. Length,
Filar Units

85.5

91.0

89.0

85.0

89.0

87.5

88.5

82.5

83.5

87.5

89.0
Dia. Length, $\mathrm{mm}$.

0.0281

0.0299

0.0292

0.0279

0.0292

0.0287

0.0291

0.0271

0,0274

0.0287

0.0292

\section{Met 8561}

$40 \mathrm{x}$ Objective

$0.3283 \times 10^{-3} \mu \mu$

(Conversion Factor)

$\underline{\mathrm{DPH}}$

235

207

218

238

218

225

219

253

247

225

218

227. 6 Aver.

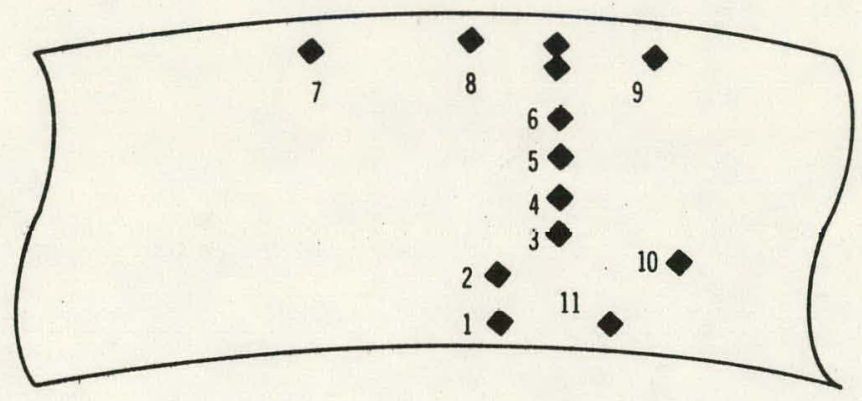




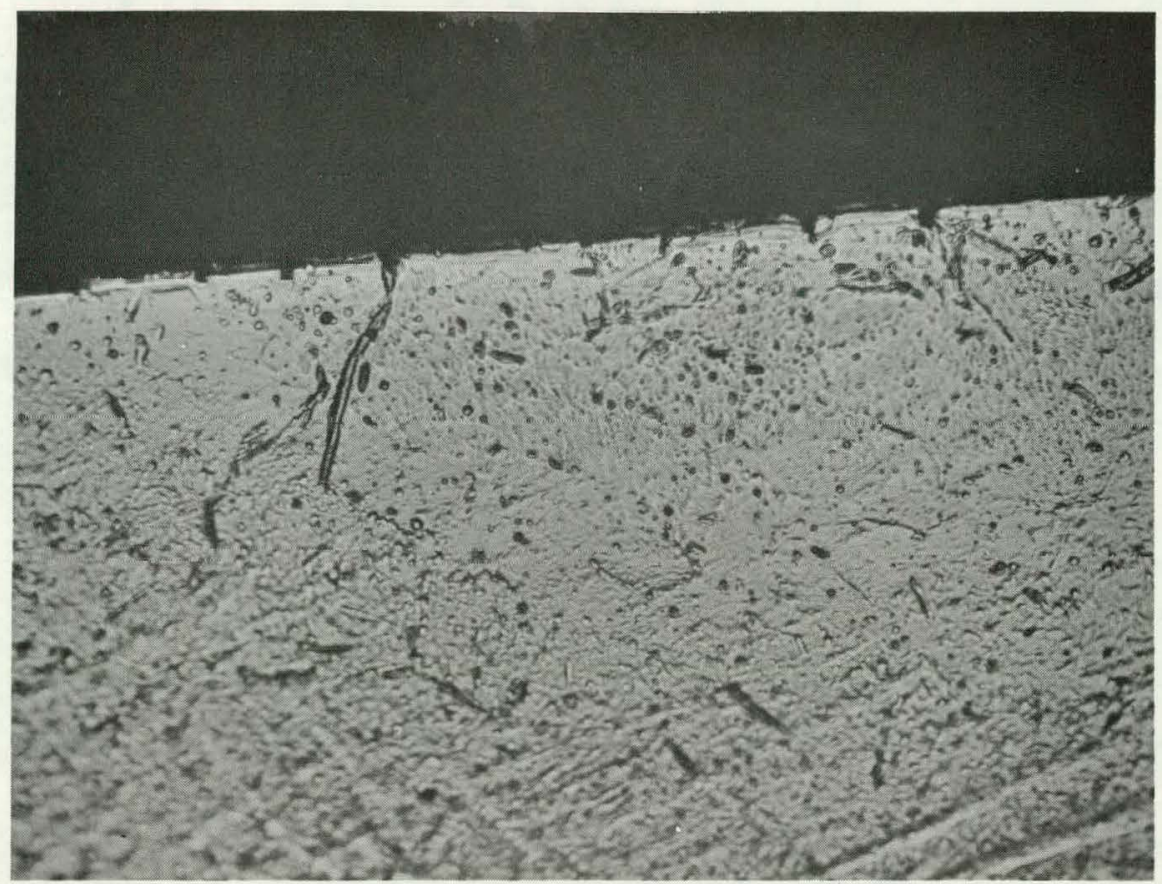

NEG. No. 8561-17

$660 x$

OUTER SURFACE OF CLADDING

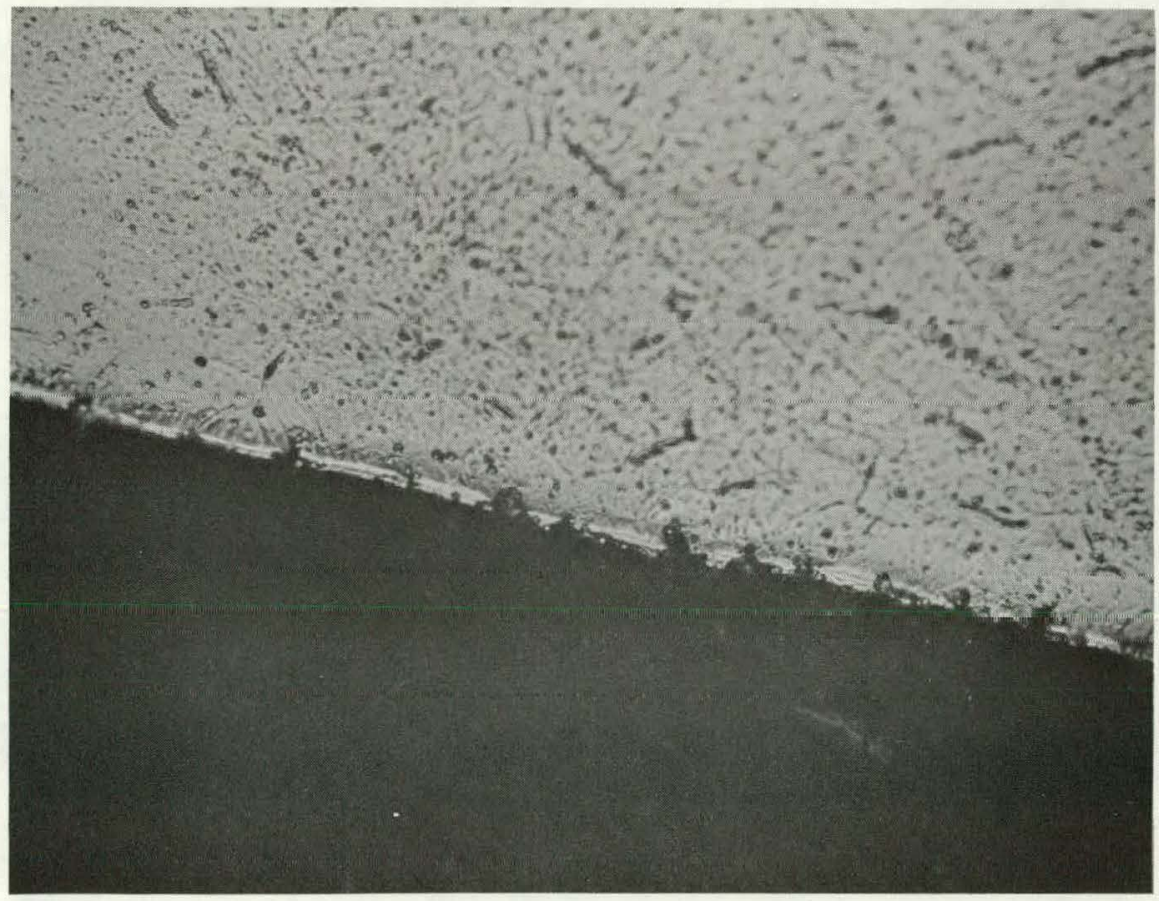

NEG. No. 8561-18

$660 x$

INNER SURFACE OF CLADDING 


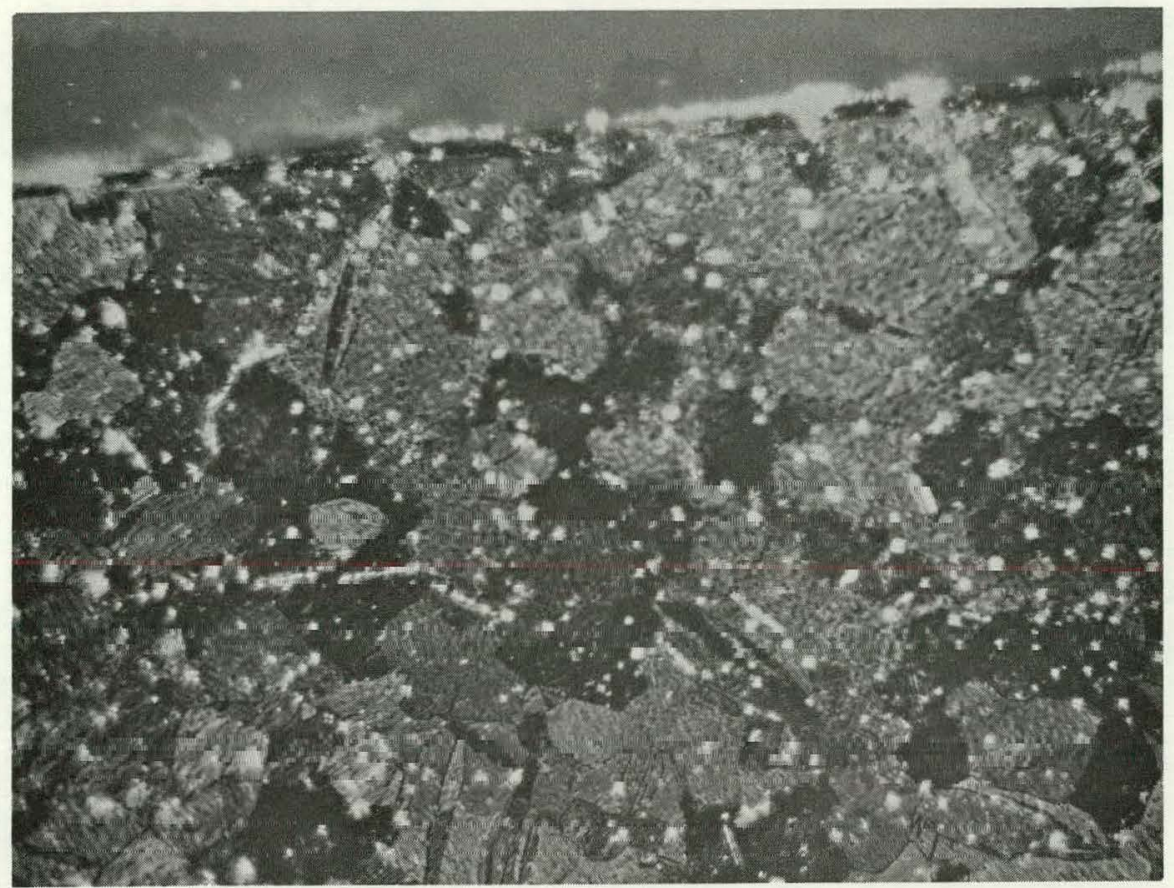

NEG. No. $8561-16$

$660 \mathrm{X}$

OUTER SURFACE OF CLADDING (AS ON

NEG. No. 8561-17).

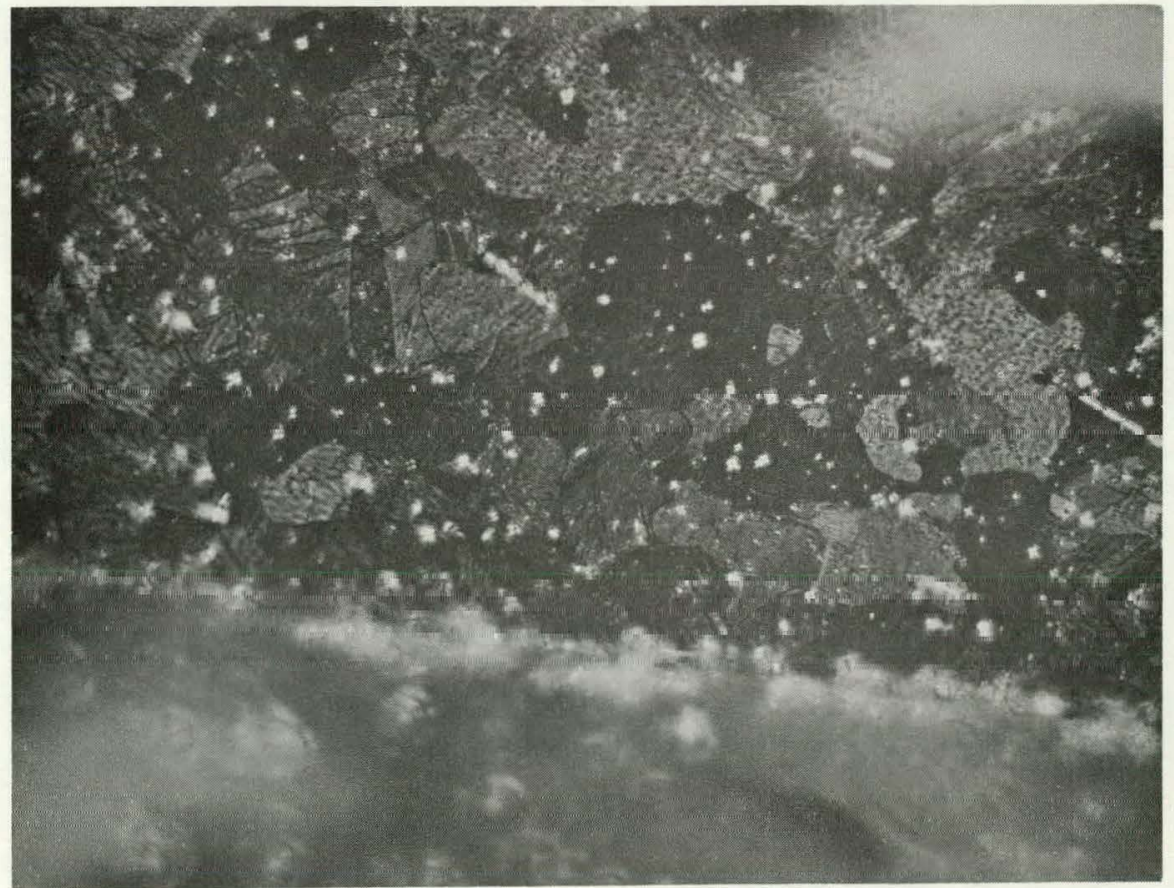

NEG. No. $8561-19$

$660 x$

INNER SURFACE OF CLADDING (AS ON NEG.

No. 8561-18). 

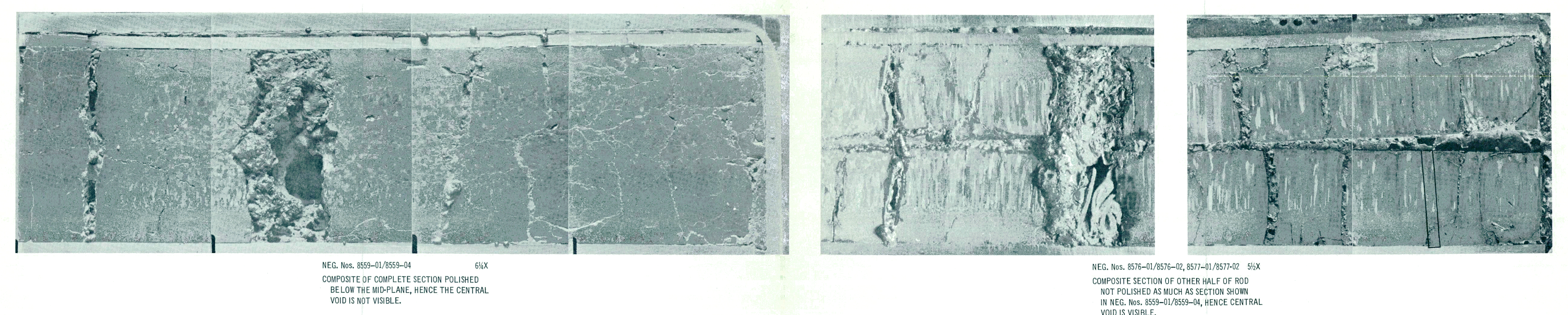

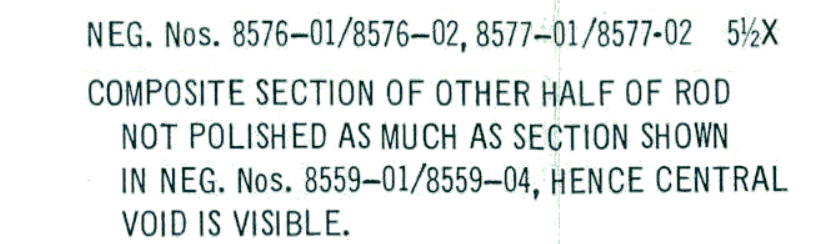




\section{ROD ELEVATION 71/2-8 Inches}

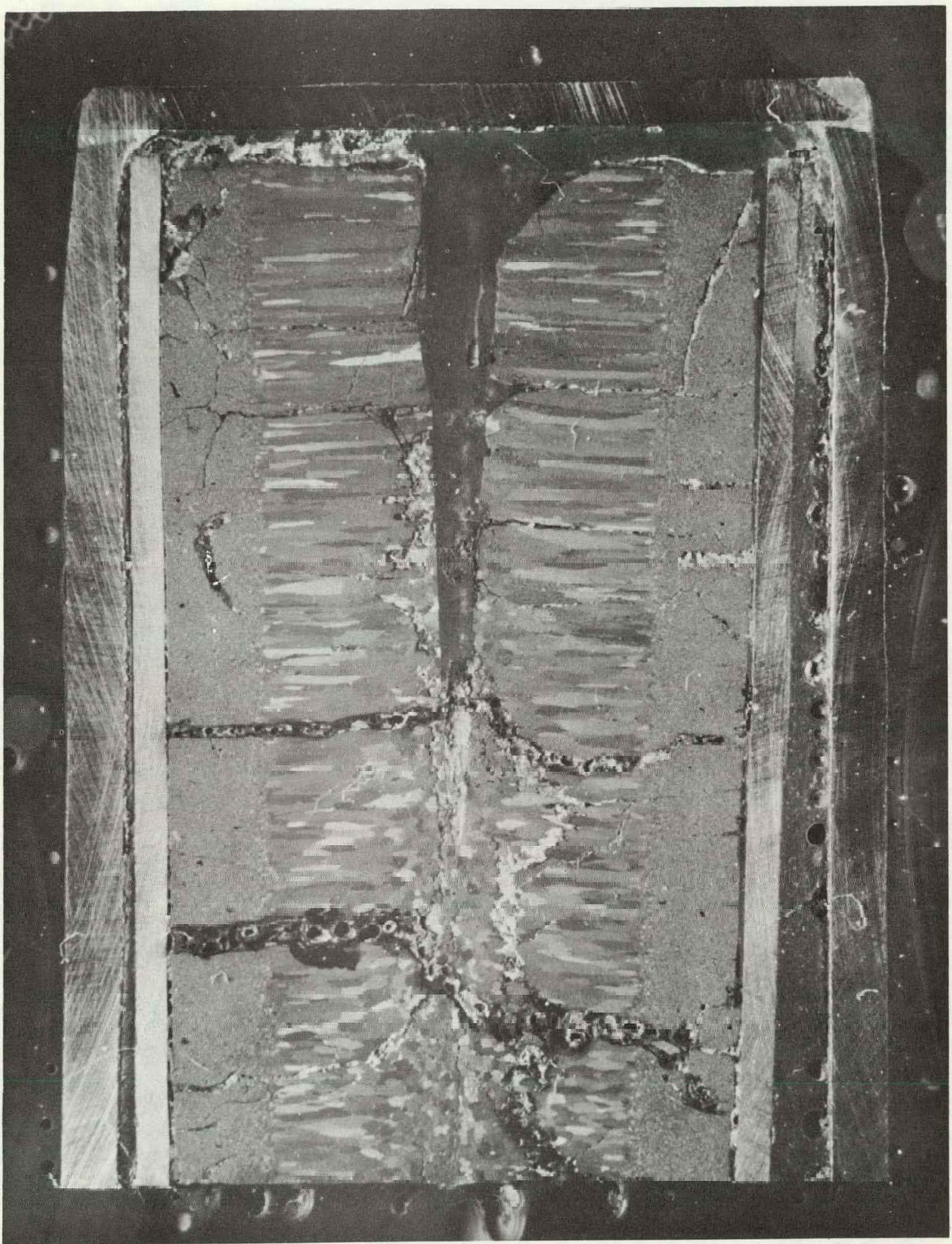

NEG. No. 8577-33 (OFF $600 \mathrm{SiC}$ )

PHOTOMACROGRAPH OF THE PARI OF THE ROD SHOWN IN 8577-01/8577-02 FURTHER POLISHED 


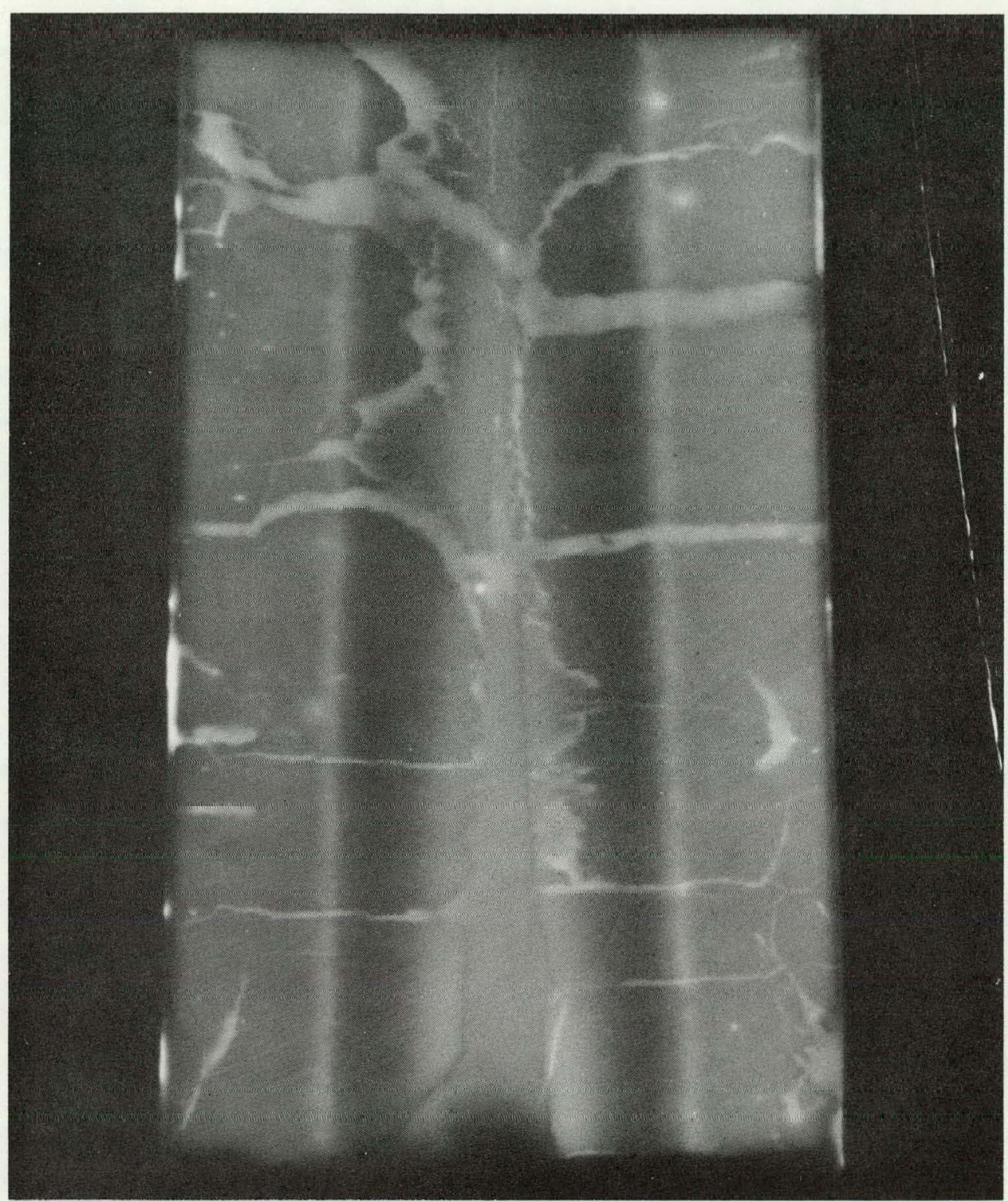

NEG. No. 8577-34

$7 X$

$\beta \cdot \boldsymbol{\gamma}$ AUTORADIOGRAPH OF THE SECTION SHOWN IN NEG. No. 8577.33

1000 


\section{ROD ELEVATION 8-9 Inches}

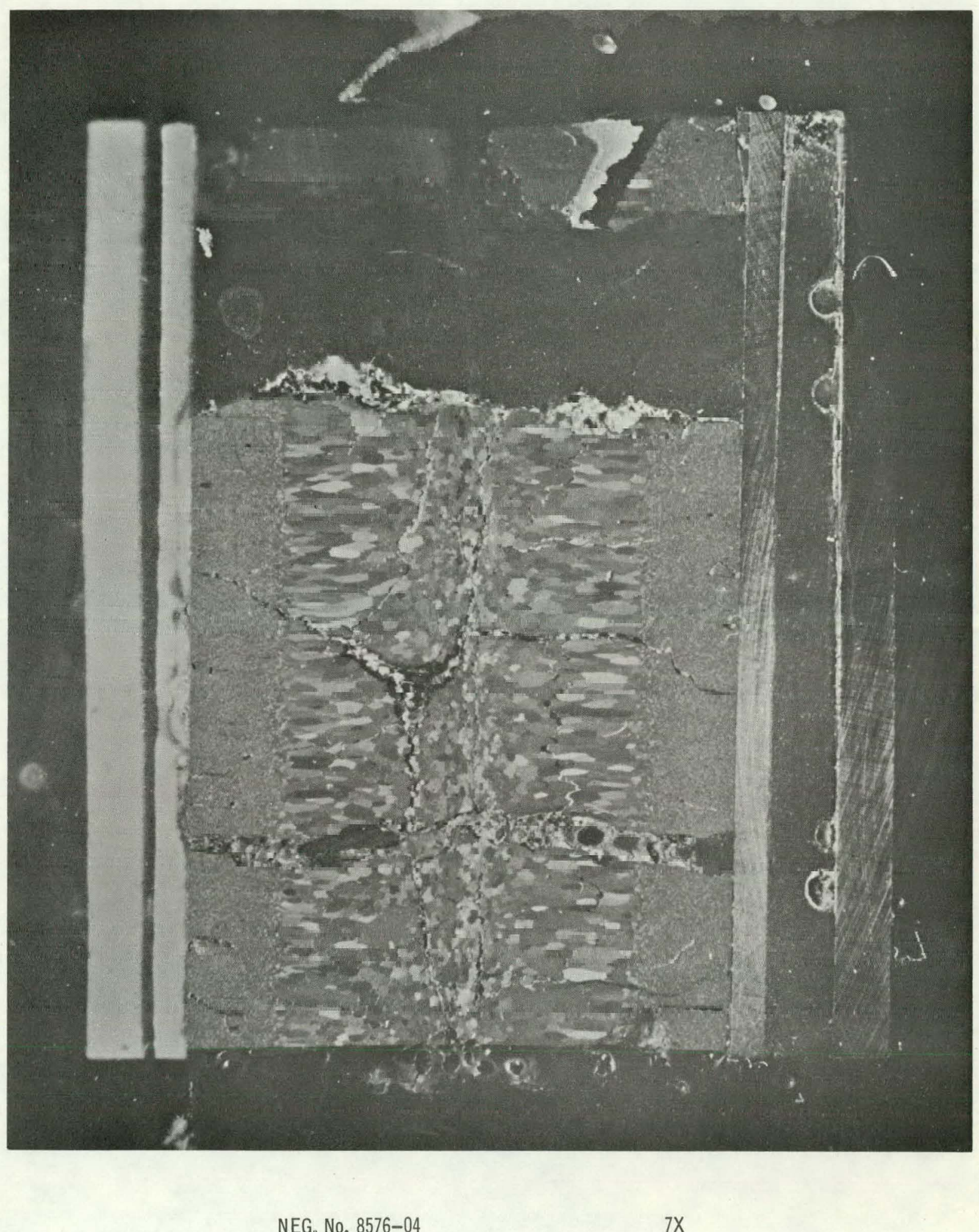

PHOTOMACROGRAPH OF THE PART OF THE ROD SHOWN IN NEG. No. 8576-01/8576-02 


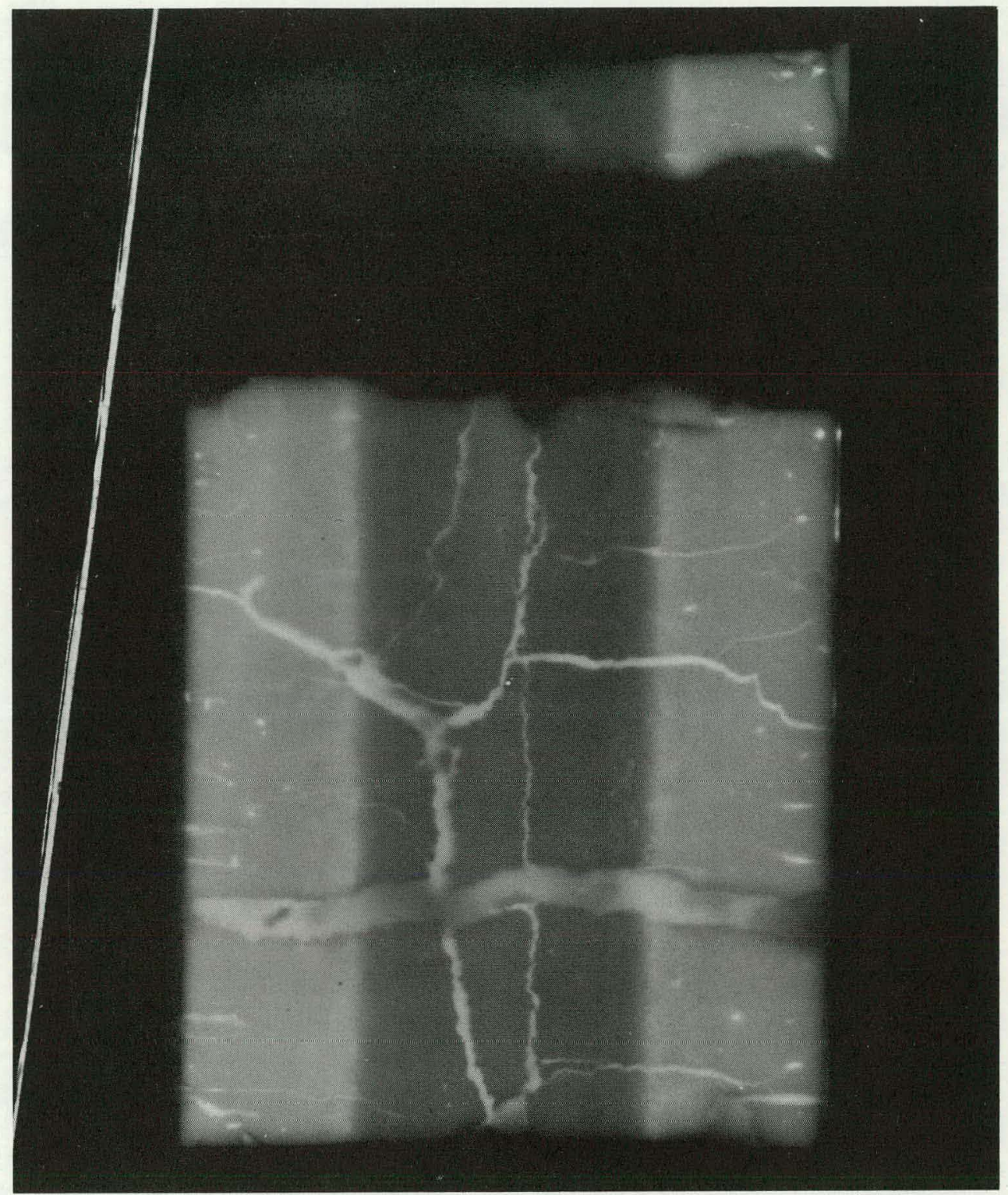

NEG. No. 8576-05

$\beta-\gamma$ AUTORADIOGRAPH OF THE SECTION SHOWN IN NEG. No. 8576-04。 


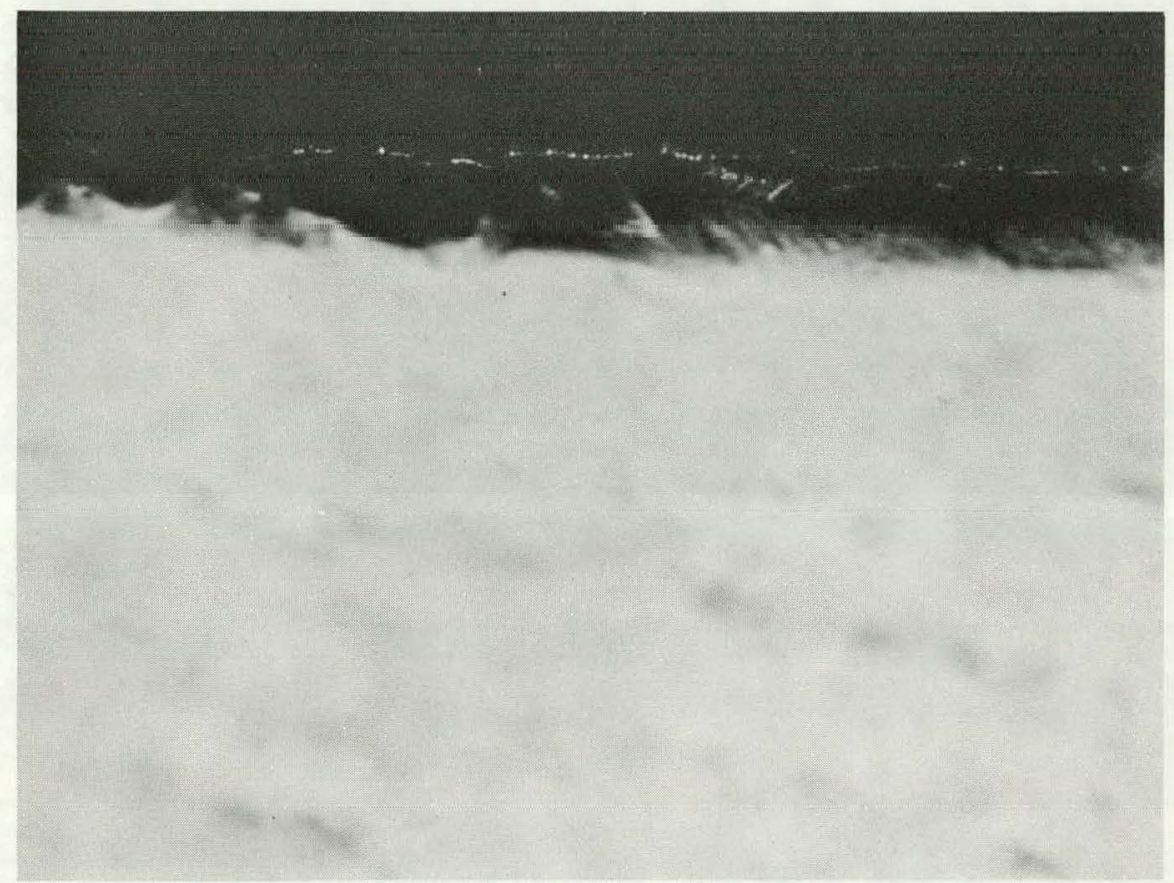

NEG. No. 8576-03

$750 \mathrm{X}$

REFERENCE PHOTOMICROGRAPH OF THE SURFACE

FILM. 


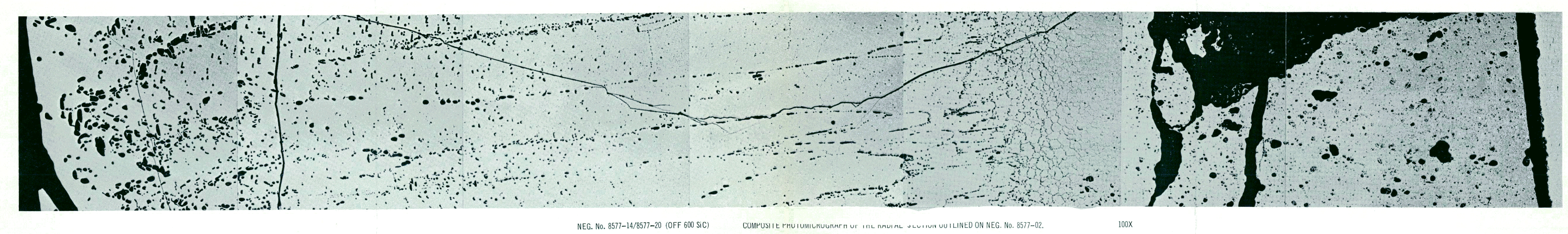




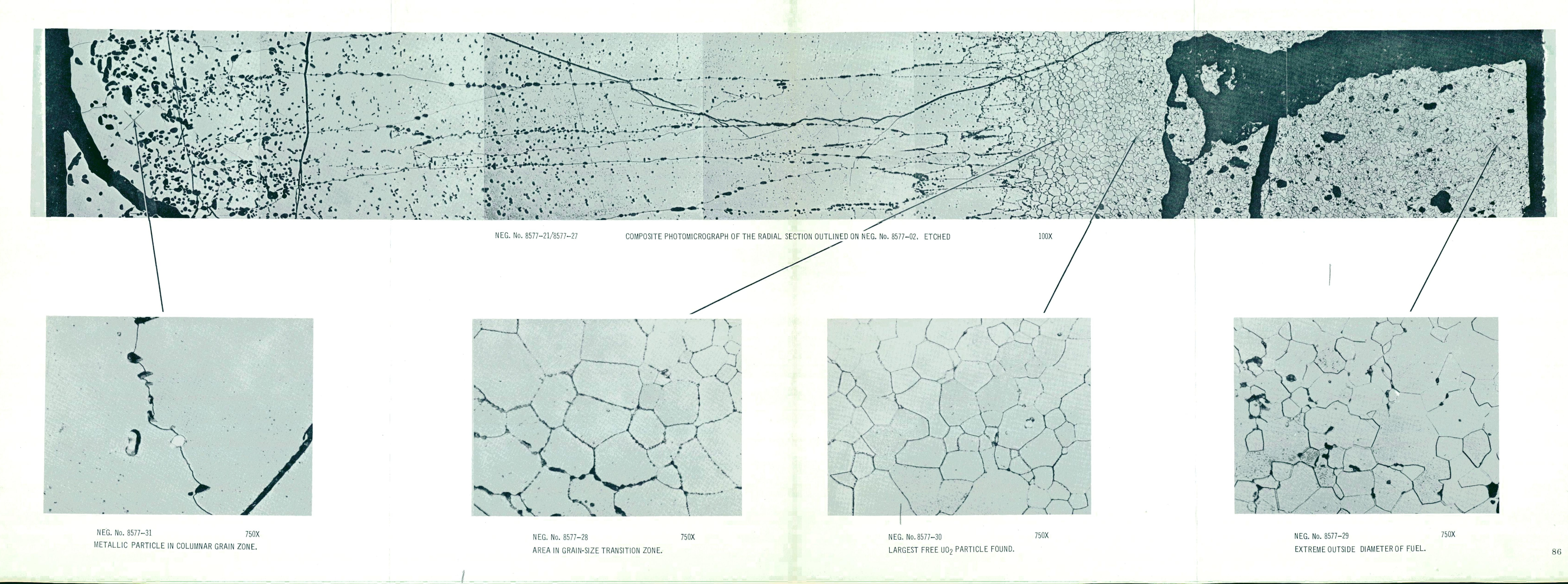




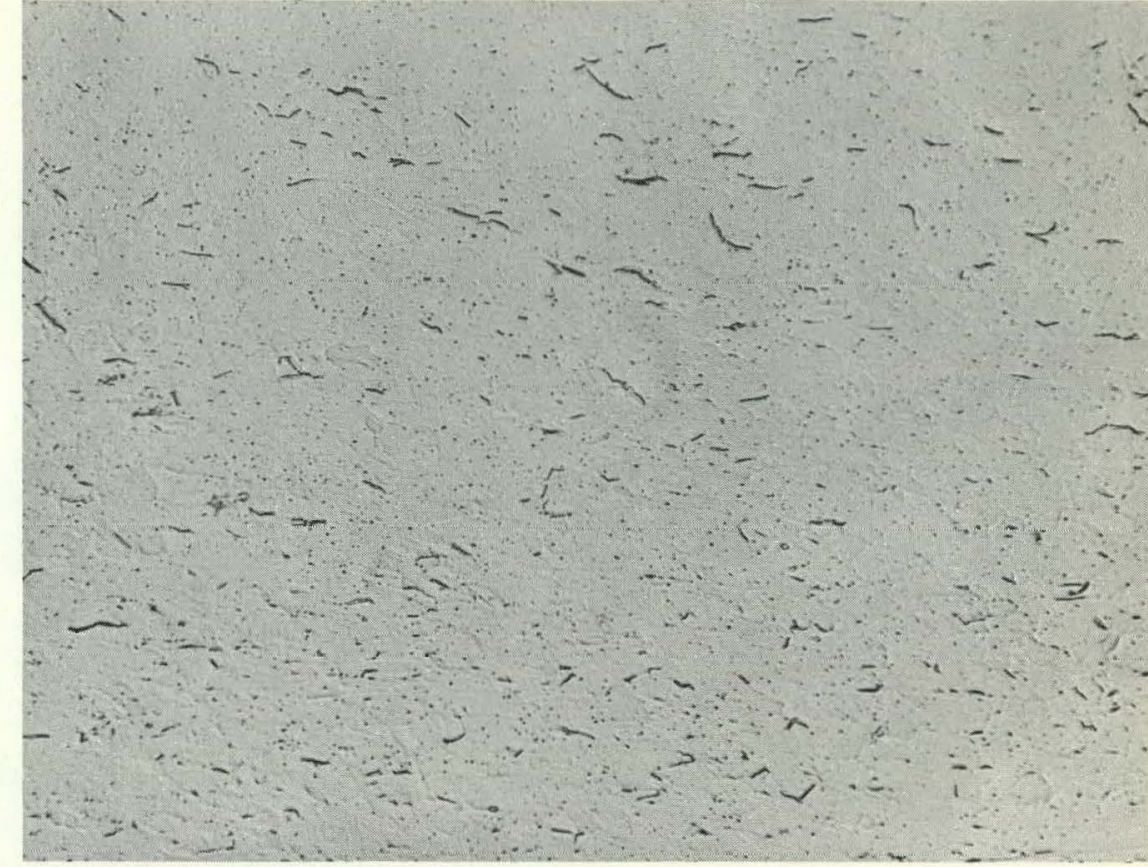

NEG. No. 8577-11 (ETCHED)

$250 x$

REPRESENTATIVE AREA SHOWING HYDRIDE

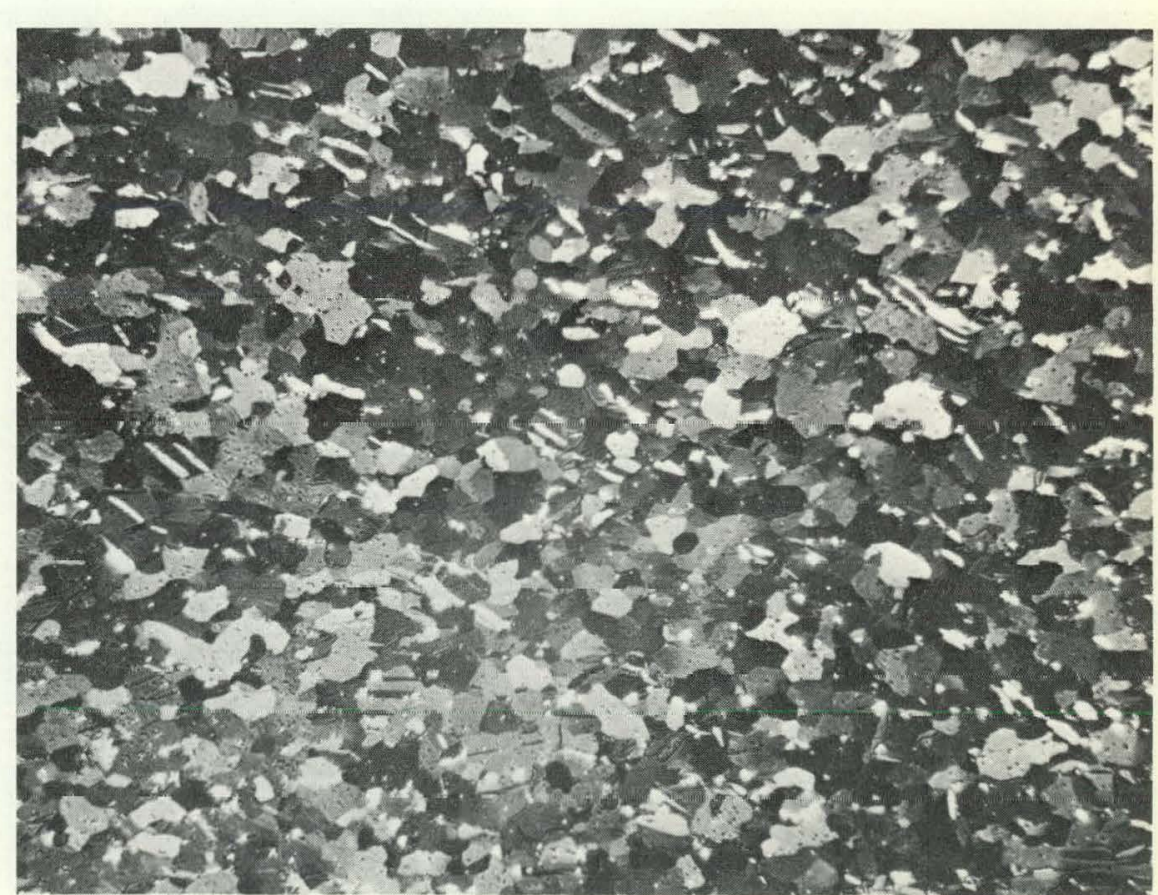

NEG. No. $8577-10$

SAME AREA AS IN NEG. No. 8577-11 USING

POLARIZED LIGHT TO SHOW GRAIN STRUCTURE.
MICROSCOPIC SECTION IN AREA OF MAXIMUM HYDRIDE IN CLAD

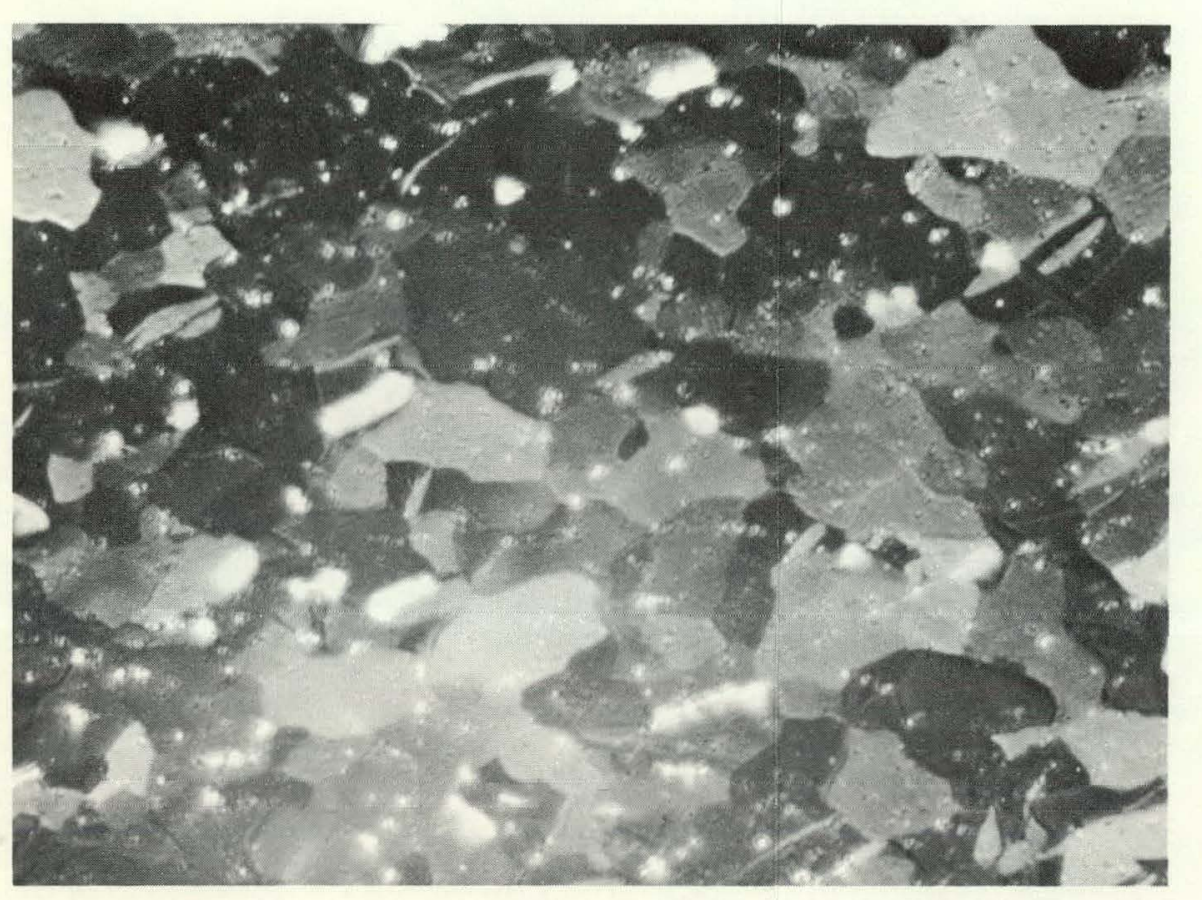

NEG. No. 8577-09

ENLARGEMENT OF AREA SHOWN IN NEG. No.

$750 x$ 


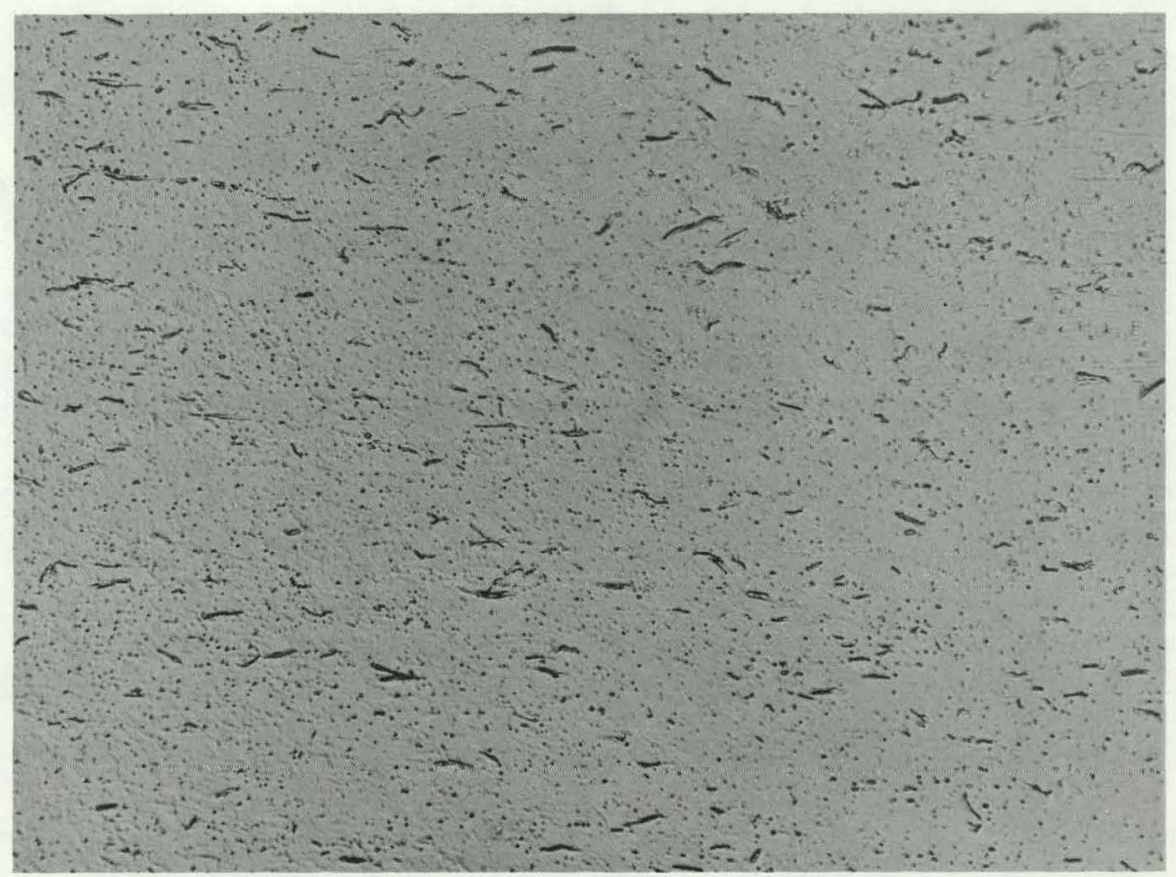

NEG. No. 8577-12 (ETCHED)

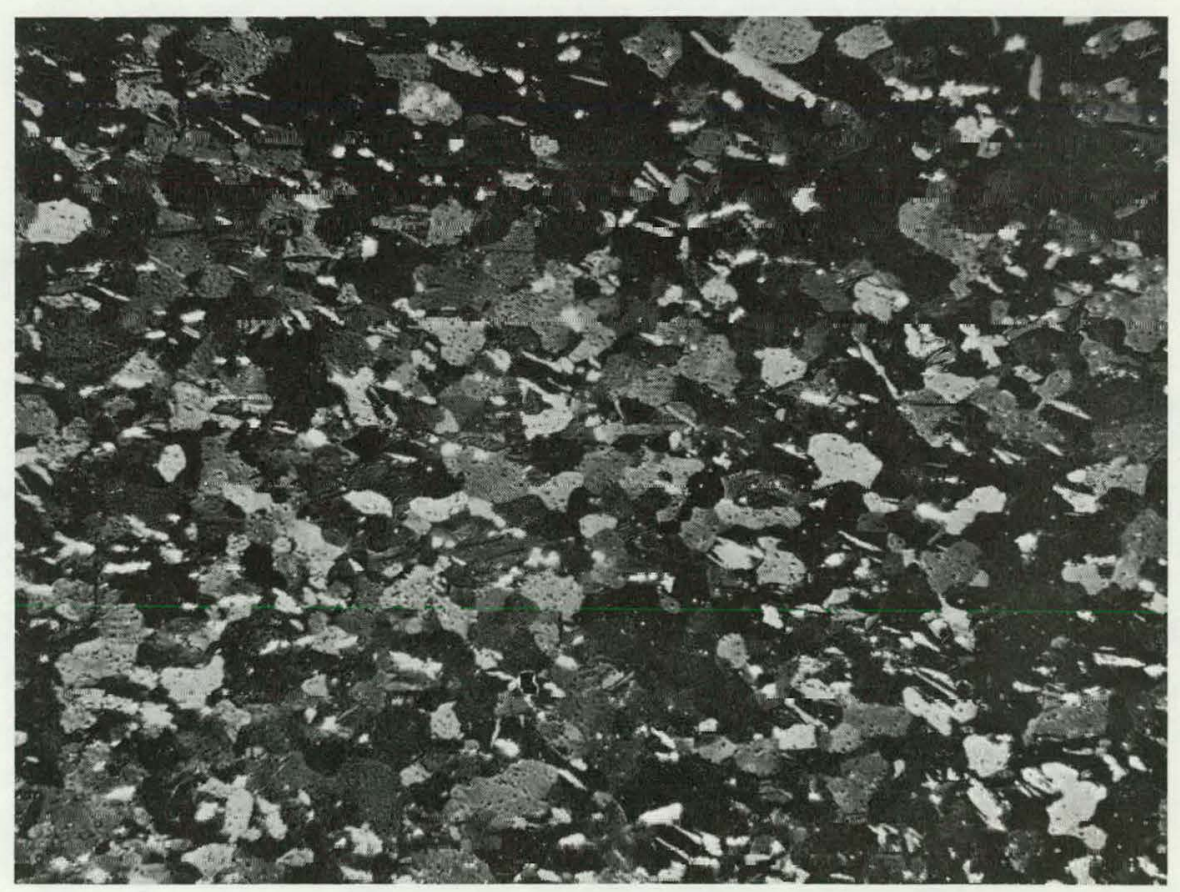

NEG. No. 8577-13 (ETCHED) 


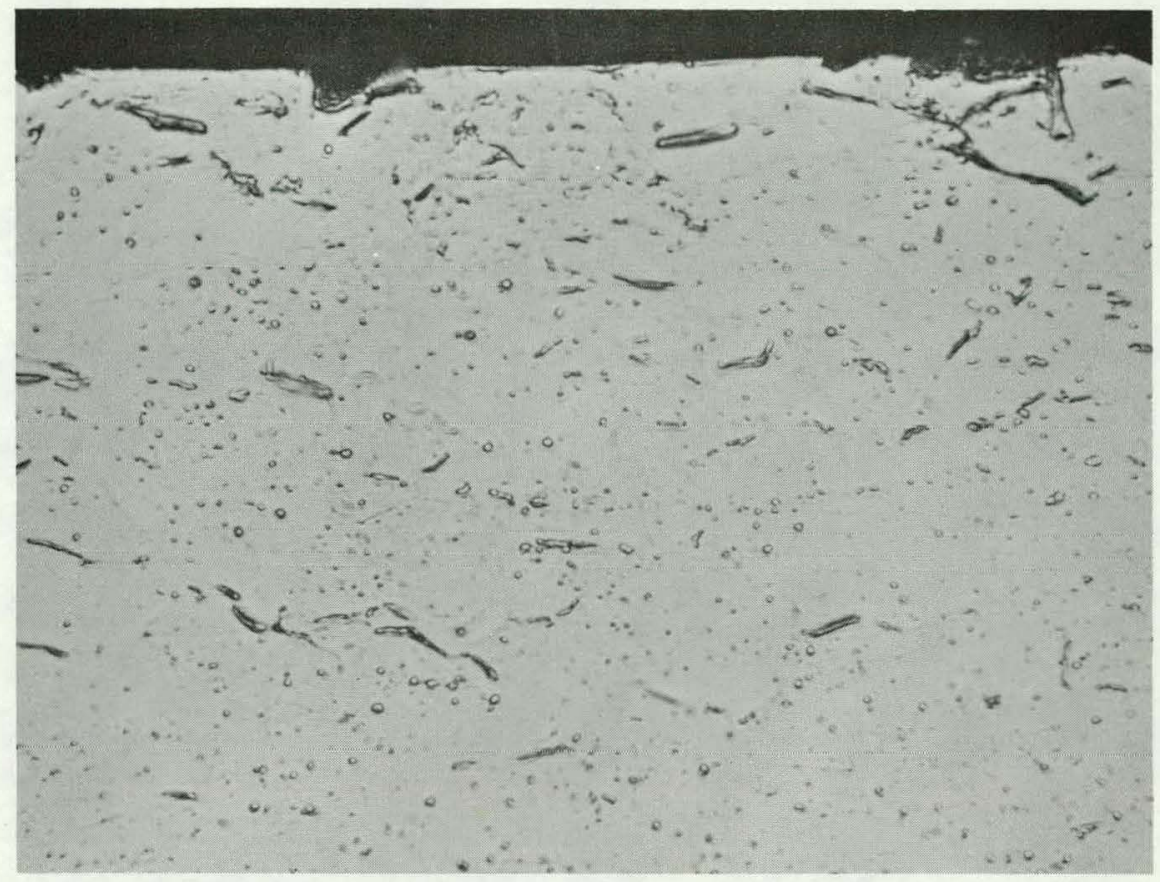

NEG. No. 8577-07 (ETCHED)

$750 X$

BRIGHT FIELD.

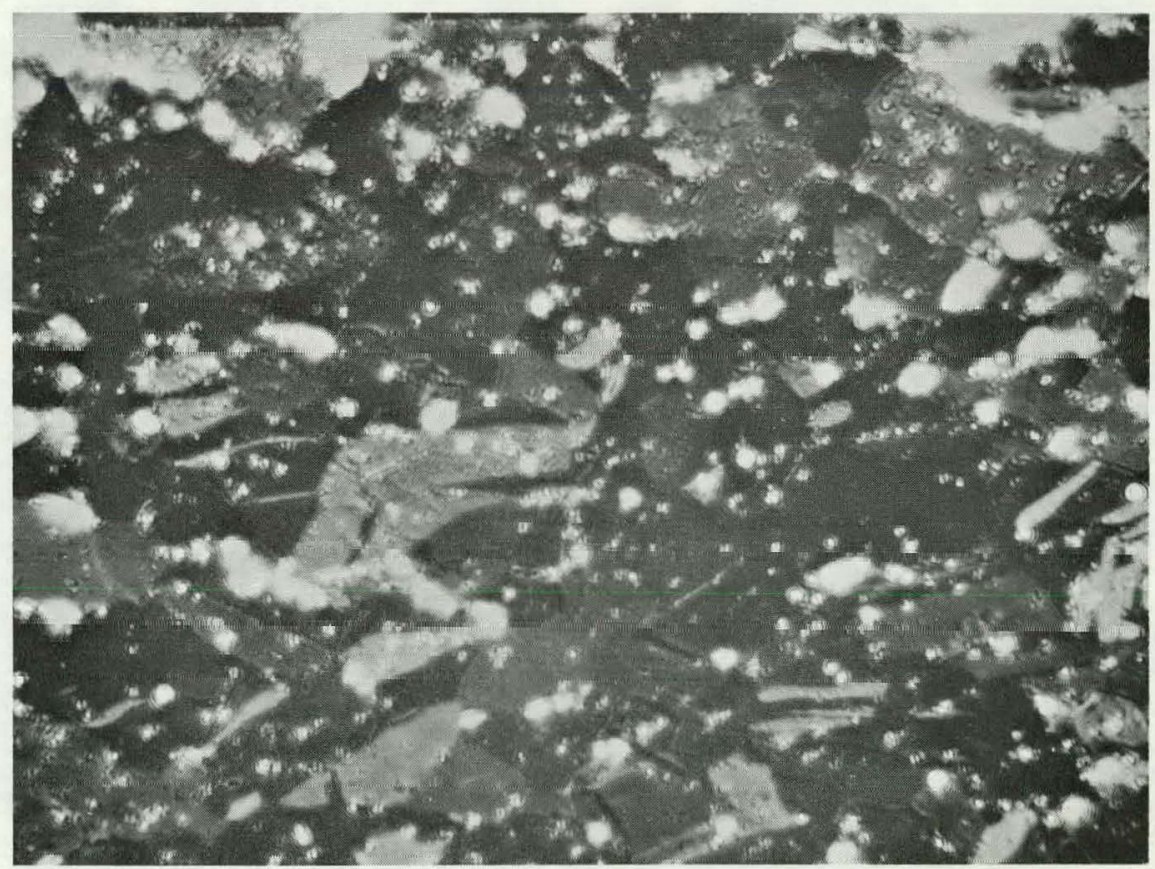

NEG. No. 8577-08

$750 x$

POLARIZED LIGHT USED TO SHOW GRAIN STRUCTURE 
GEAP-5100A

CLAD CORROSION AT ZONE OF MAXIMUM SWELLING

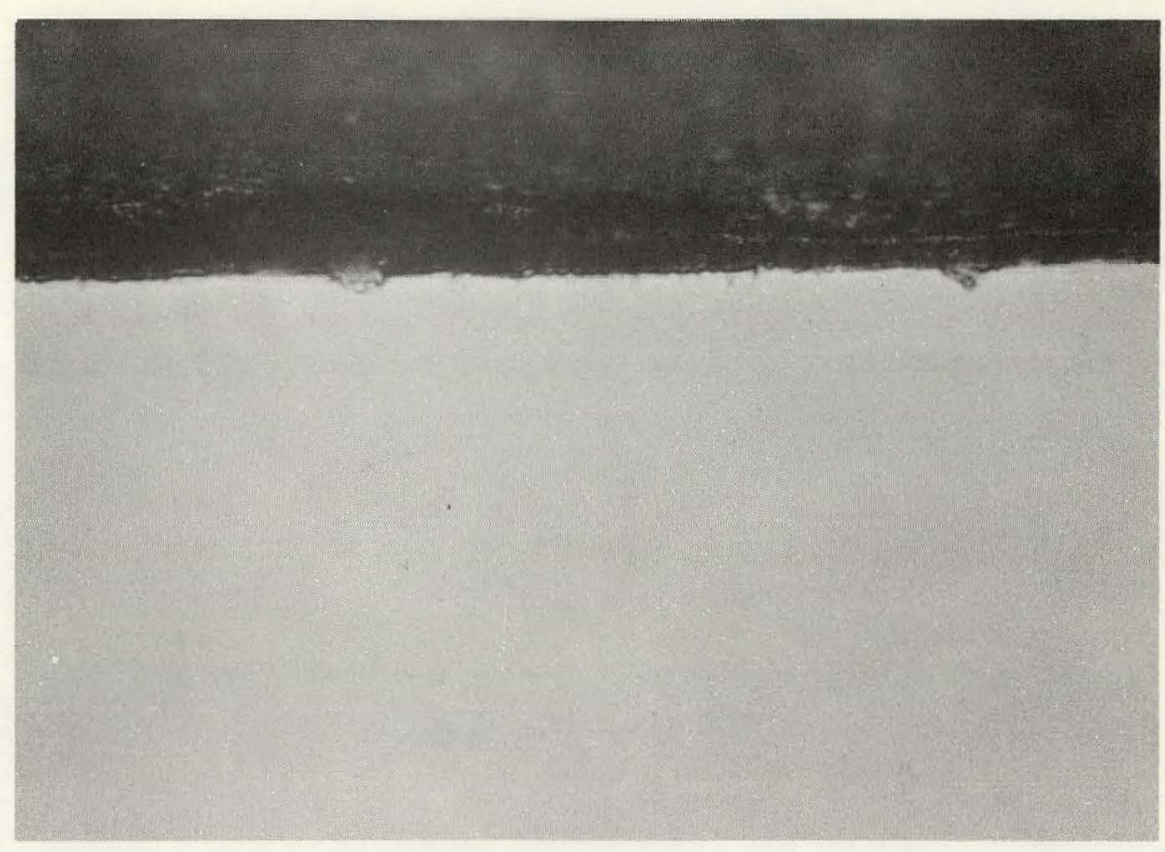

PACKING COMPOUND

CLAD O.D.

NEG. No. 8577-03 (OFF $1 \mu$ )

$750 X$

CORROSION FILM ON ONE SIDE OF ZONE.

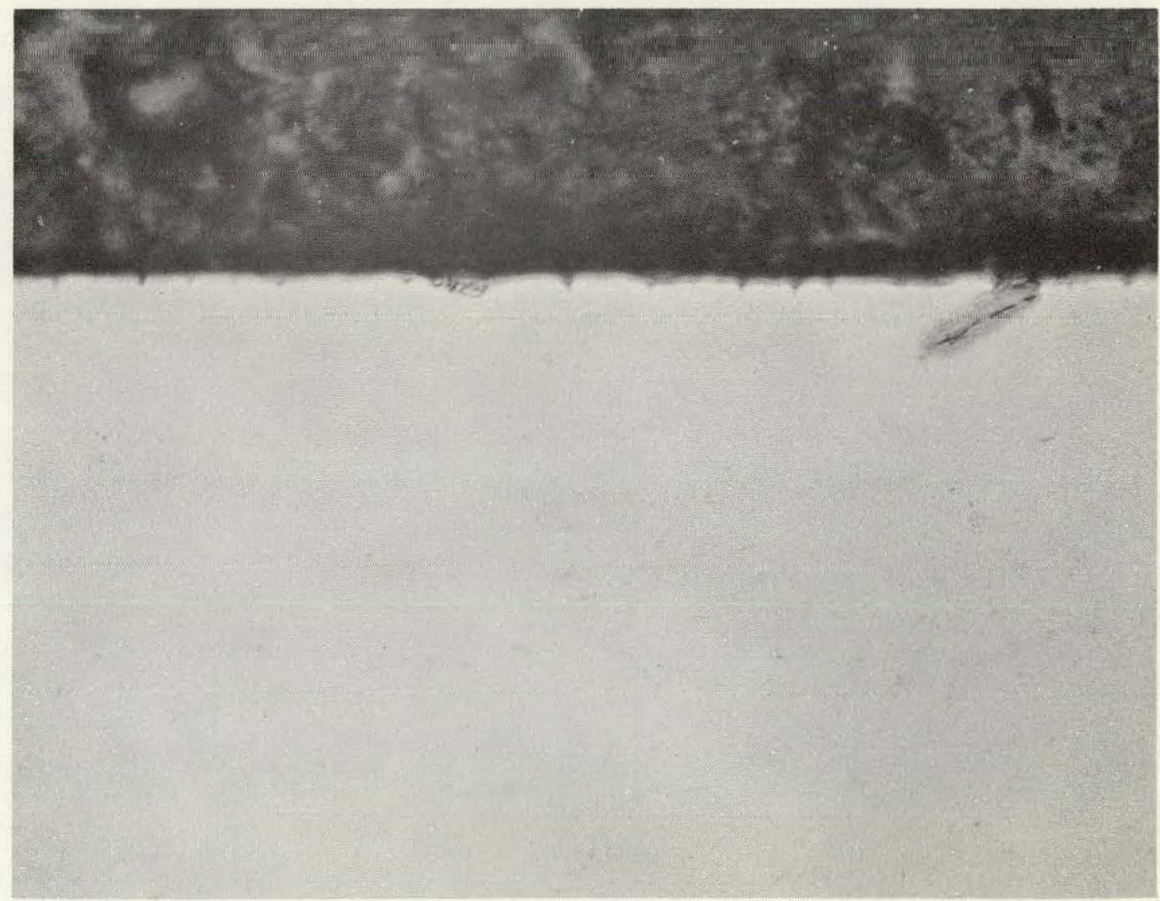

PACKING COMPOUND

CLAD O.D.

NEG. No. 8577-04 (OFF $1 \mu$ )

$750 \mathrm{X}$

CORROSION FILM ON OTHER SIDE OF ZONE. 


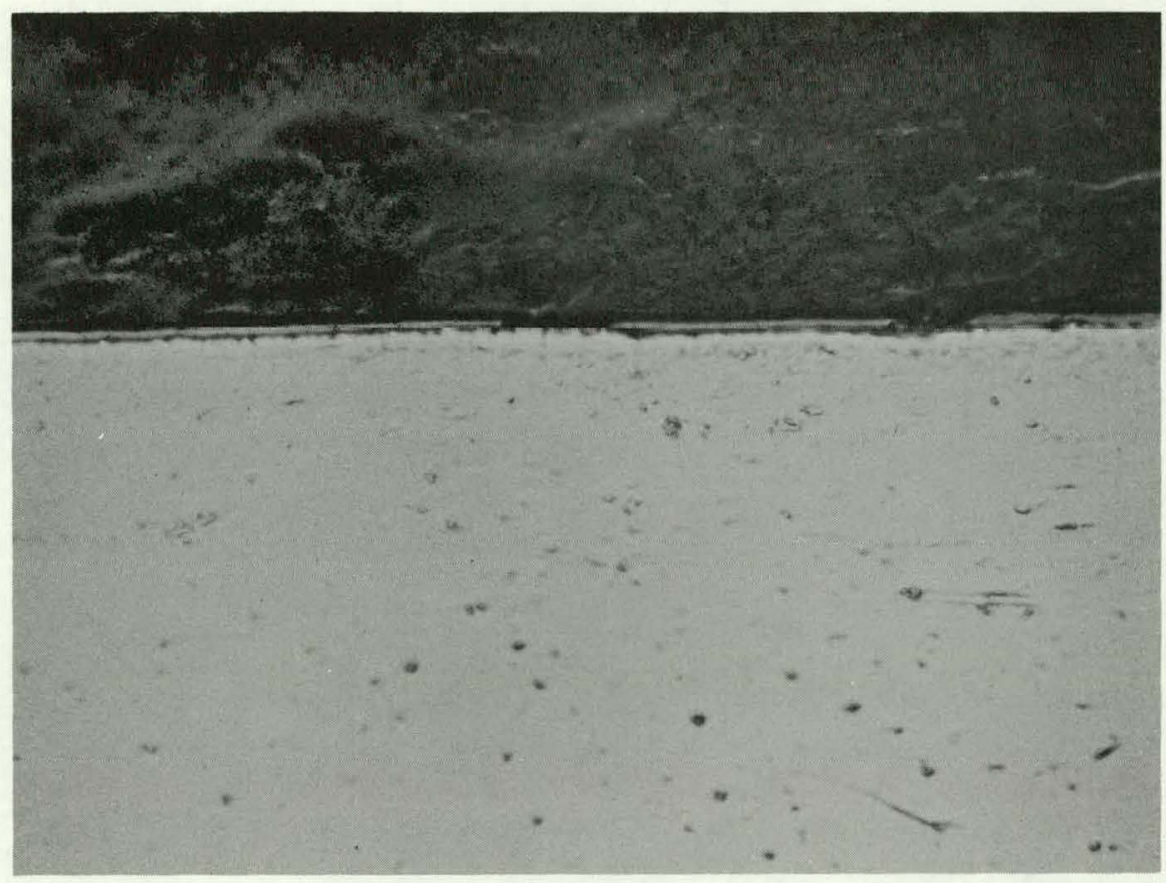

NEG. No. 8577-06 (OFF $1 / 4 \mu)$

$750 X$

FINER POLISHING OF CLADDING EDGE TO SHOW CORROSION FILM

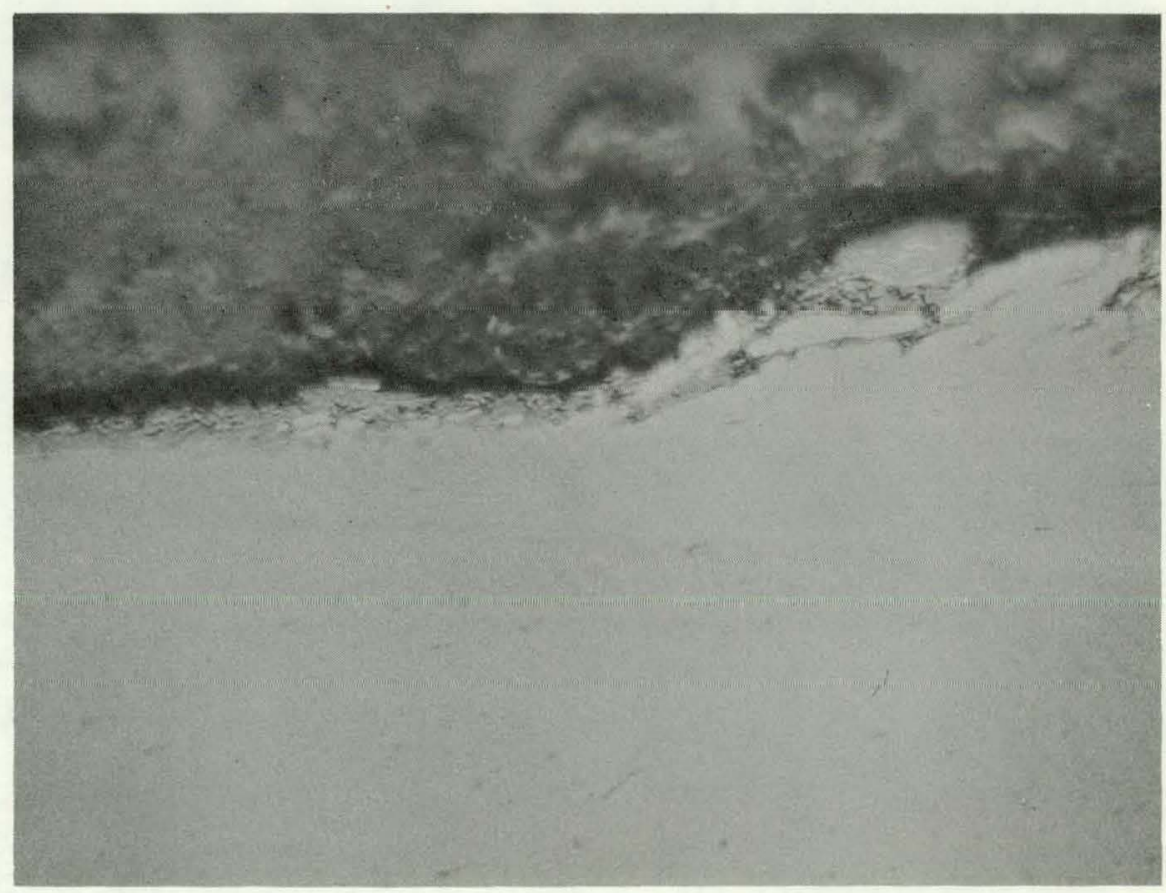

NEG. No. 8577-05 (OFF $1 \mu$ )

$750 X$

MAXIMUM CORROSION IN UNIQUE AREA. 


\title{
EPT-6 ROD.D
}

\author{
MAXIMUM BURNUP ZONE
}

ROD ELEVATION 18 Inches FROM BOT TOM 


\section{ROD ELEVATION 18 Inches}

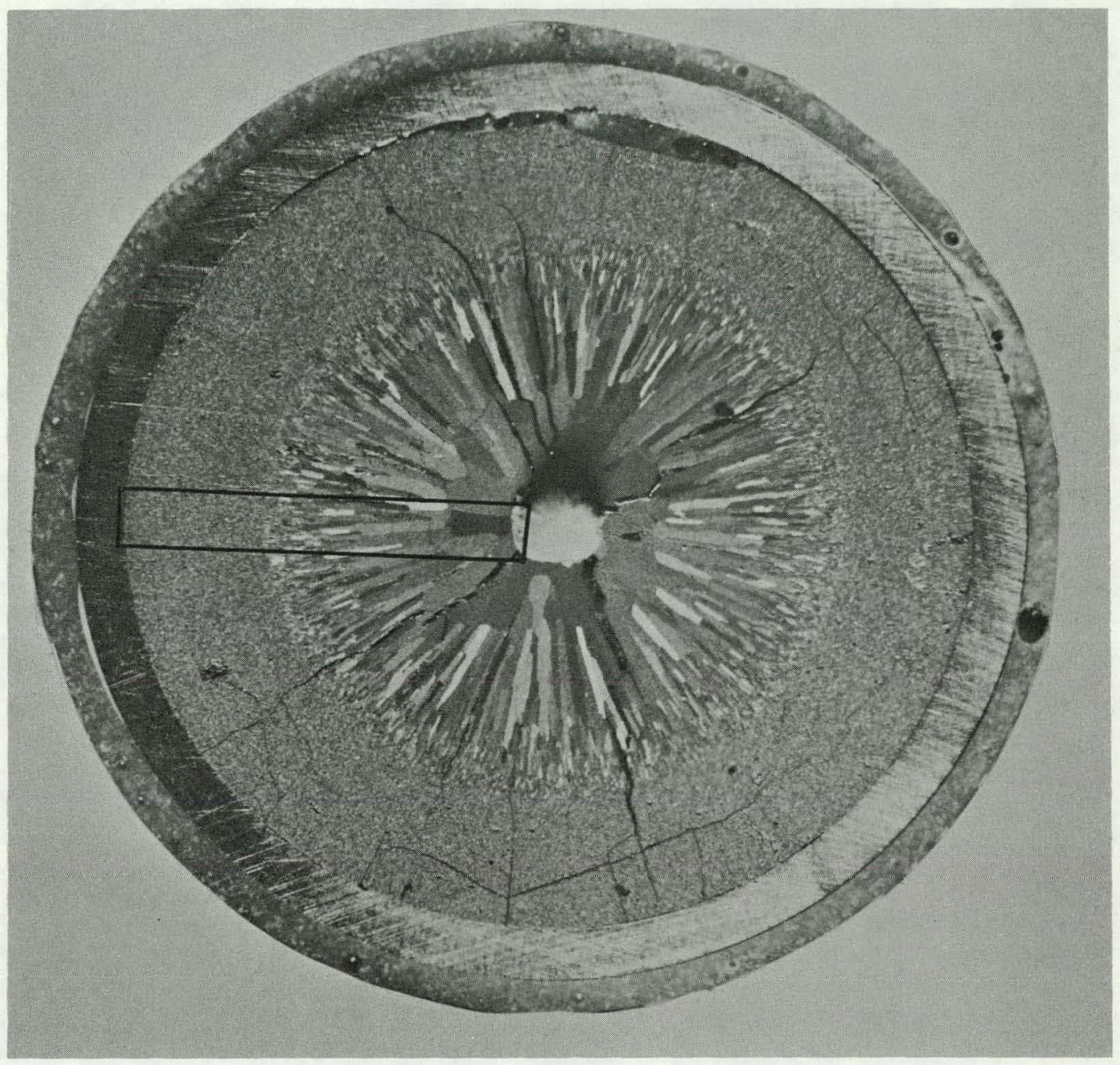

NEG. No. 8560-01

$8 X$

PHOTOMACROGRAPH OF TRANSVERSF FIJEL.

ROD SECTION AT ZONE OF MAXIMUM BURNUP

BETWEEN P.ELLETS 34 AND 35. 
ROD ELEVATION 18 Inches

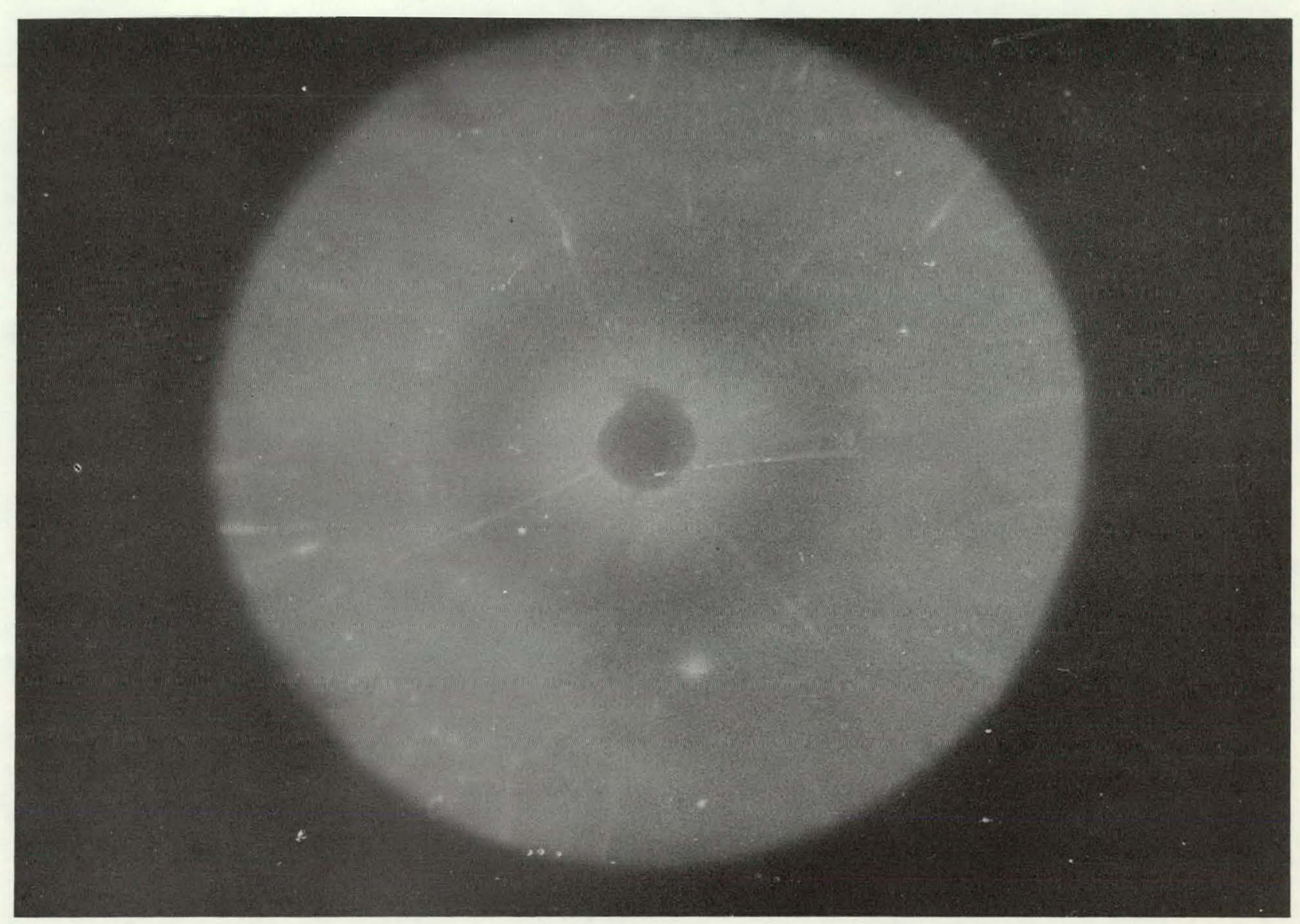

NEG. No. 8560-00

$8 X$

$\beta \cdot \boldsymbol{\gamma}$ AUTORADIOGRAPH OF SECTION SHOWN

IN NEG. No. 8560-01

330 
ROD ELEVATION 18 Inches

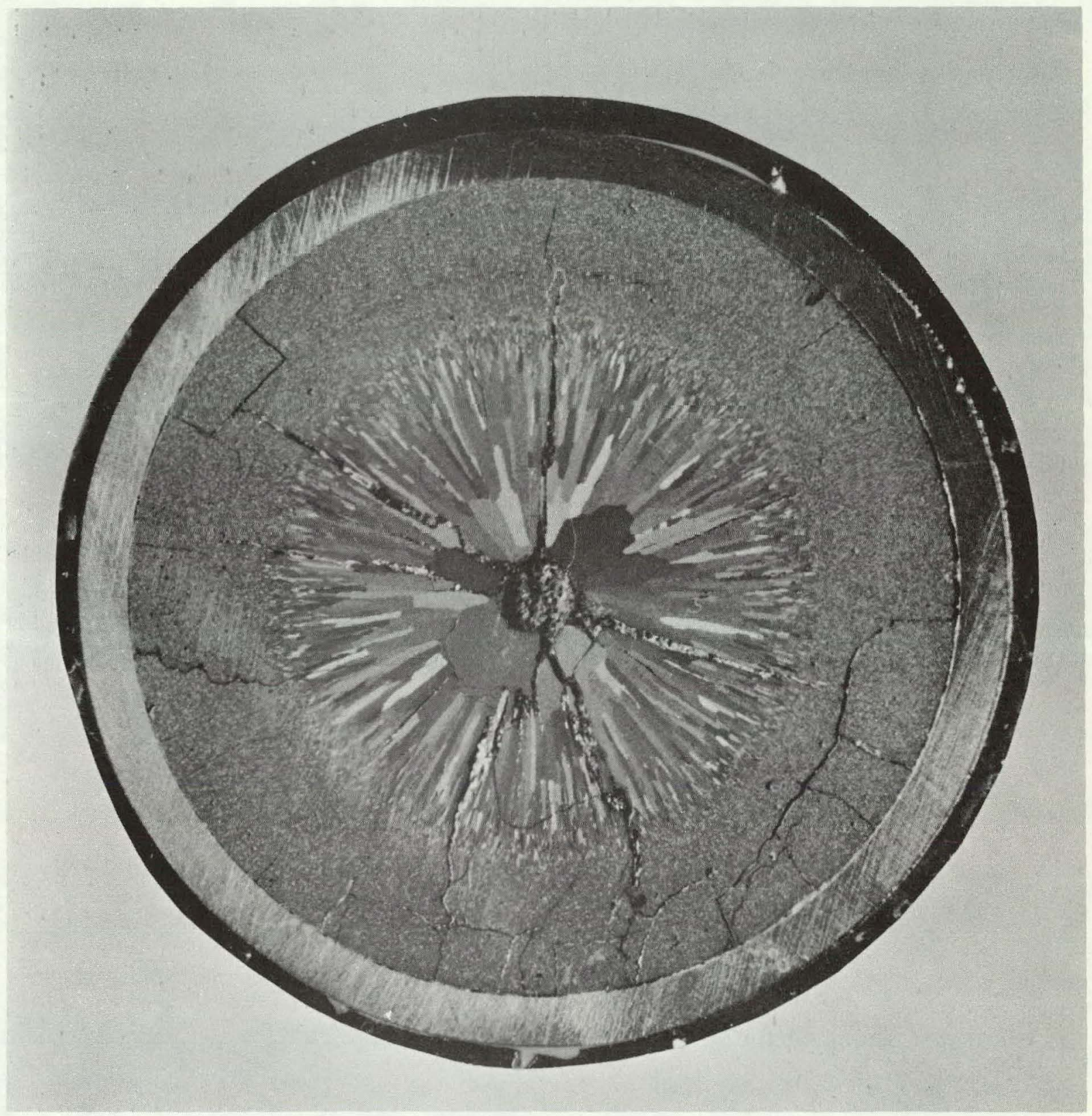

NEG. No. 8560-23 (OFF $600 \mathrm{SiC})$

PHOTOMACROGRAPH OF TRANSVERSE FUEL ROD SECTION AT MAXIMUM BURN-UP ZONE BETWEEN ESTIMATED PELLETS 34 \& 35. 
ROD ELEVATION 18 Inches

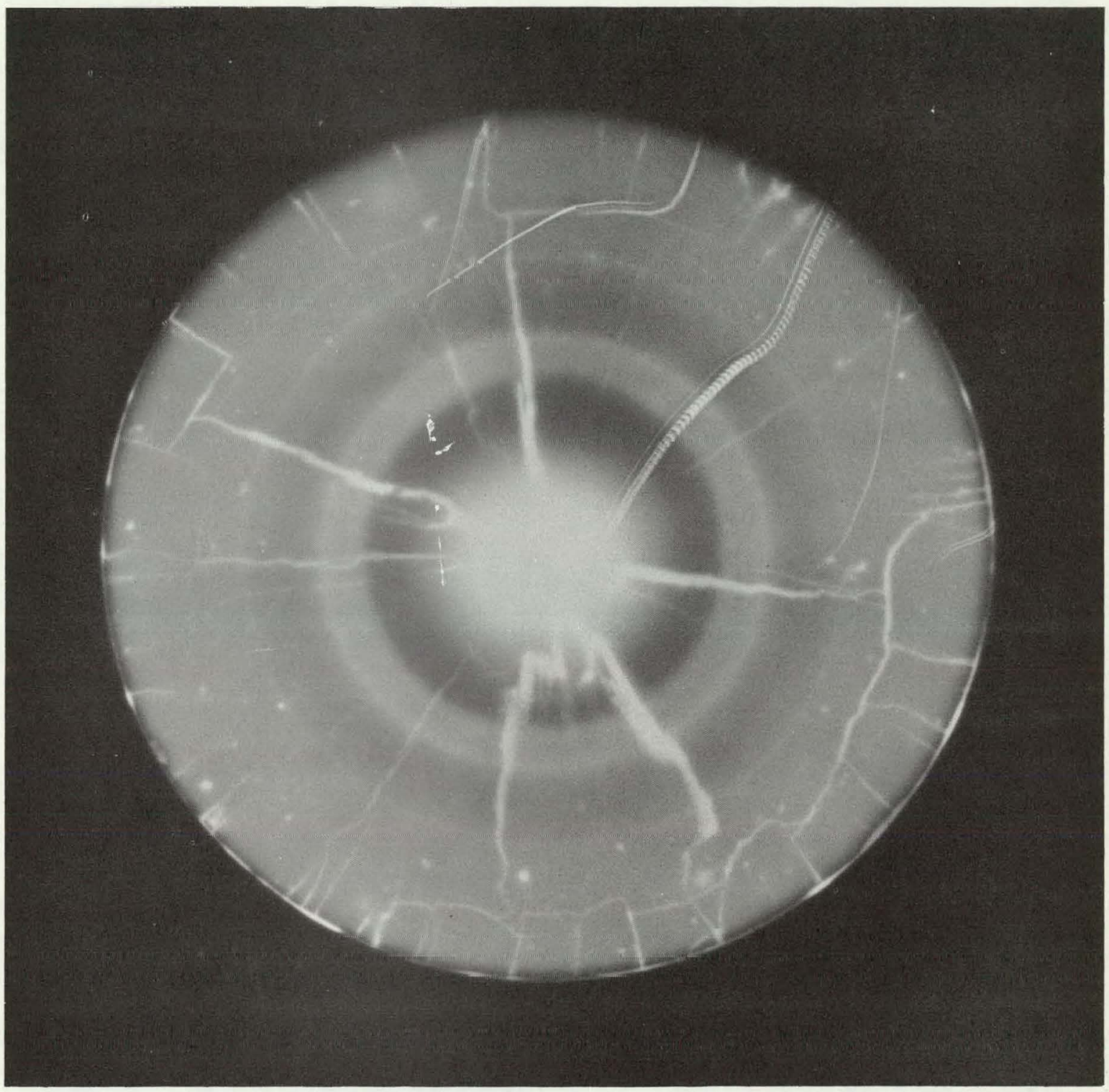

NEG. No. 8560-24 $10 \mathrm{X}$

$\beta \cdot \gamma$ AUTORADIOGRAPH OF SAME SECTION AS IN NEG. No. 8560--23. 

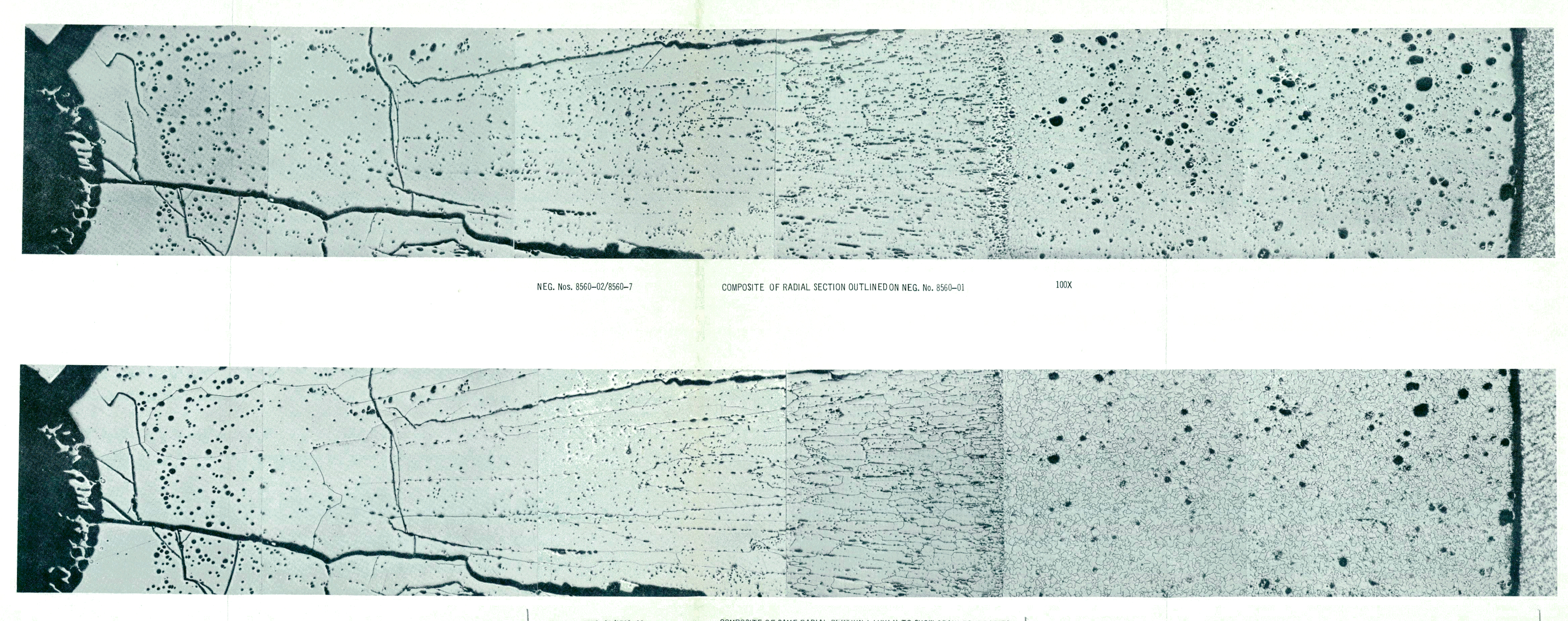
GEAP-5100A

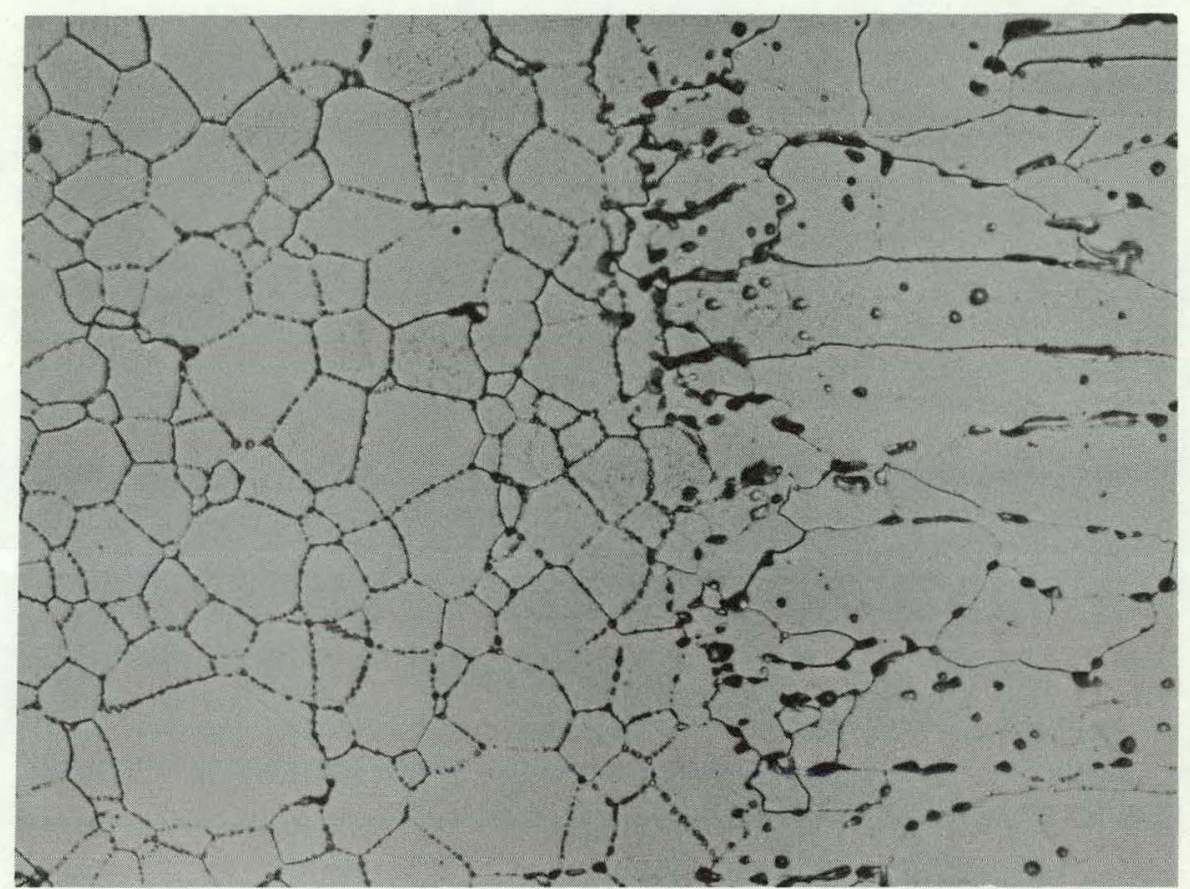

NEG. No. $8560-14$

$500 x$

TRANSITION REGION BETWEEN COLUMNAR AND EQUIAXED GRAINS IN RADIAL SECTION ON NEG. Nos. 8560-08/8560-13 (PAGE 66), SHOWS POROSITY (OR 2nd PHASE) IN BOUNDARIES OF SMALL EQUIAXED GRAIN. 

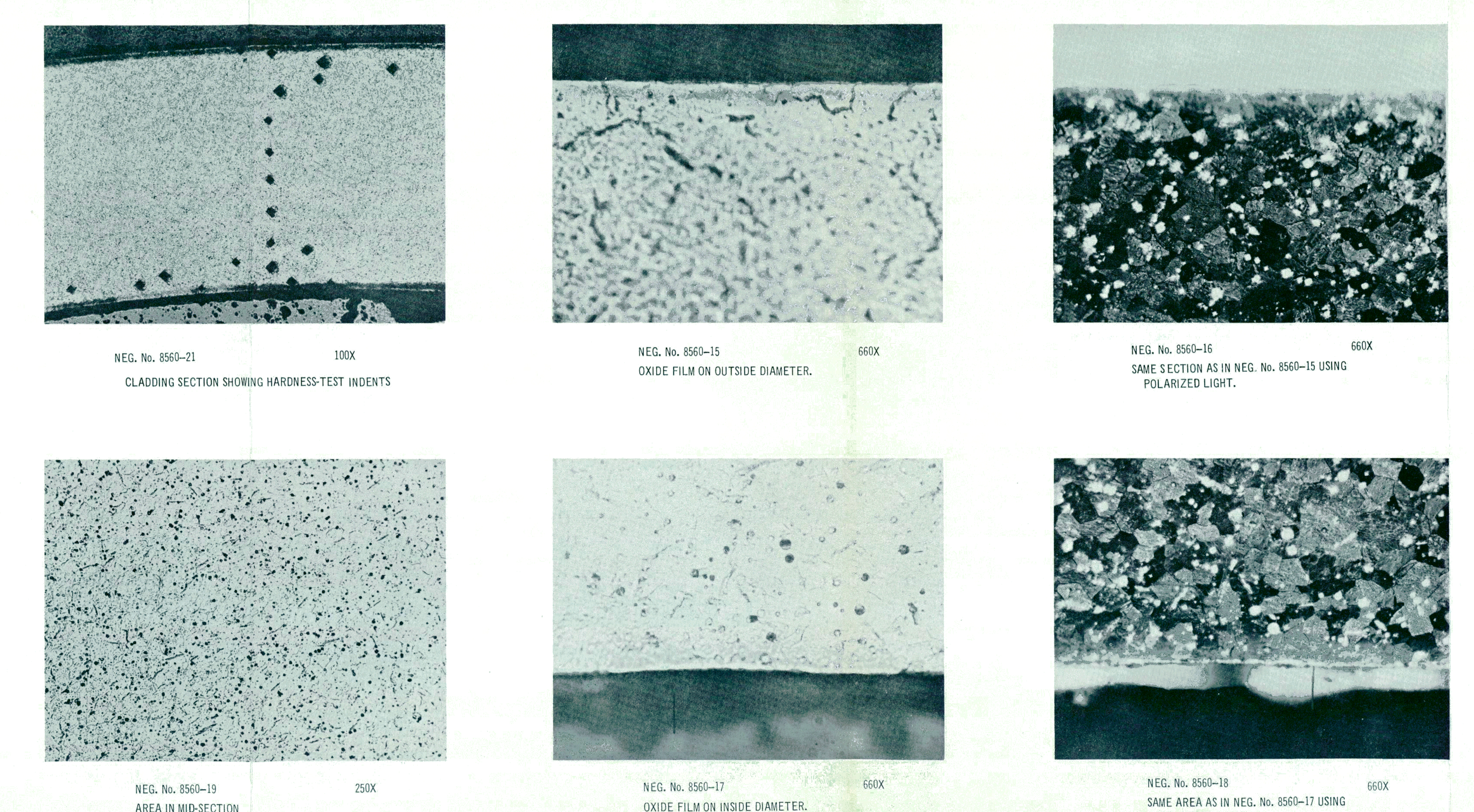

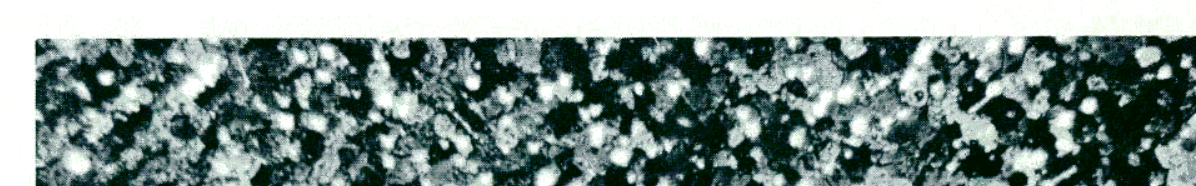

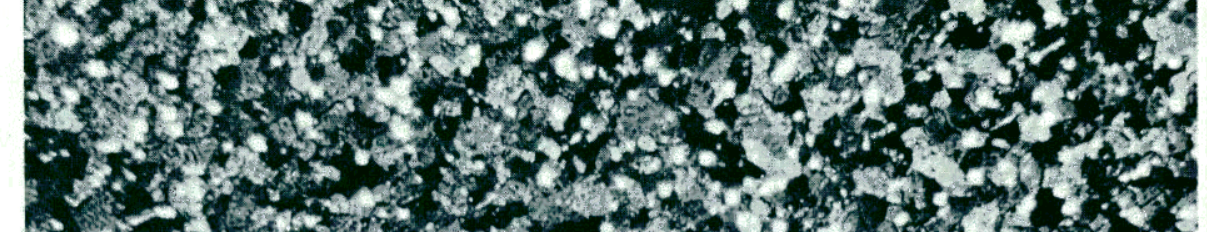

420,50
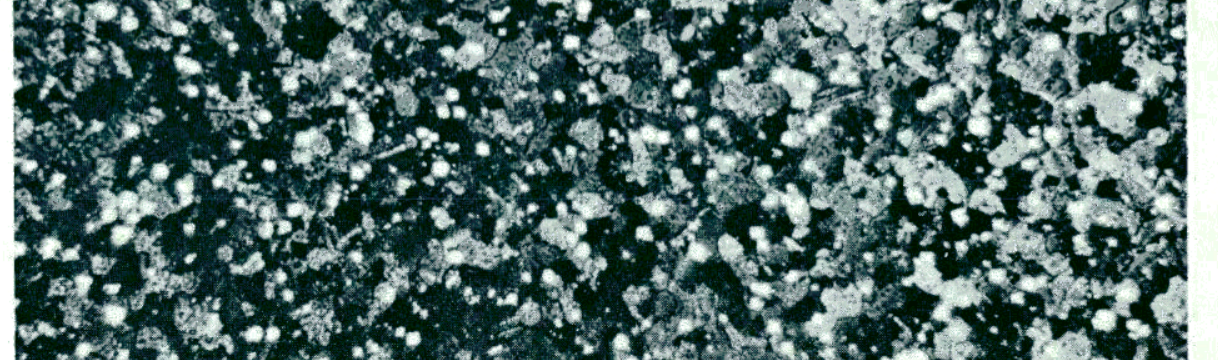

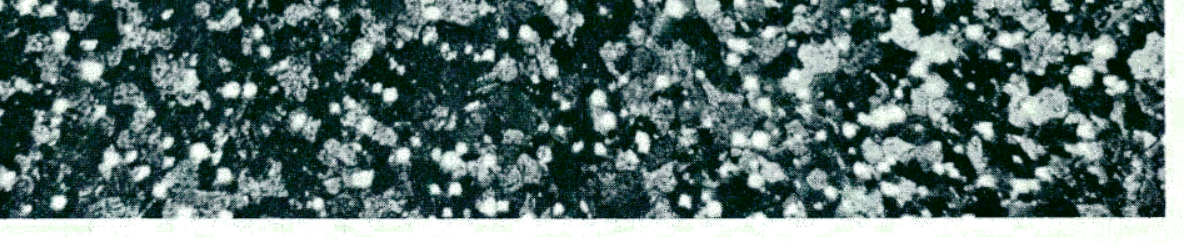

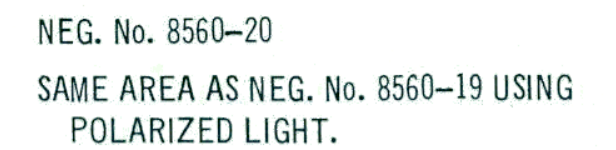


TABLE 10.

\section{MICROHARDNESS DATA SHEET}

EPT 6-D

Maximum Burnup Region

$0.1 \mathrm{~kg}$ Load

\begin{tabular}{c} 
Test No. \\
\hline 1 \\
2 \\
3 \\
4 \\
5 \\
6 \\
7 \\
8 \\
9 \\
10 \\
11 \\
12 \\
13
\end{tabular}

Aver. Dia. Length, Filar Units

93.5

112.5

103.0

118.0

86.5

88.0

91.0

97.5

88.0

111.0

86.5

107. 0

71.5
Dia. Length, $\mathrm{mm}$.

0.0307

0.0369

0.0338

0.0387

0.0284

0.0289

0.0298

0.0320

0.0287

0.0364

0.0284

0.0351

0.0235
Met 8560

$40 \mathrm{x}$ Objective

$0.3283 \times 10^{-3} \mu \mu$

(Conversion Factor)

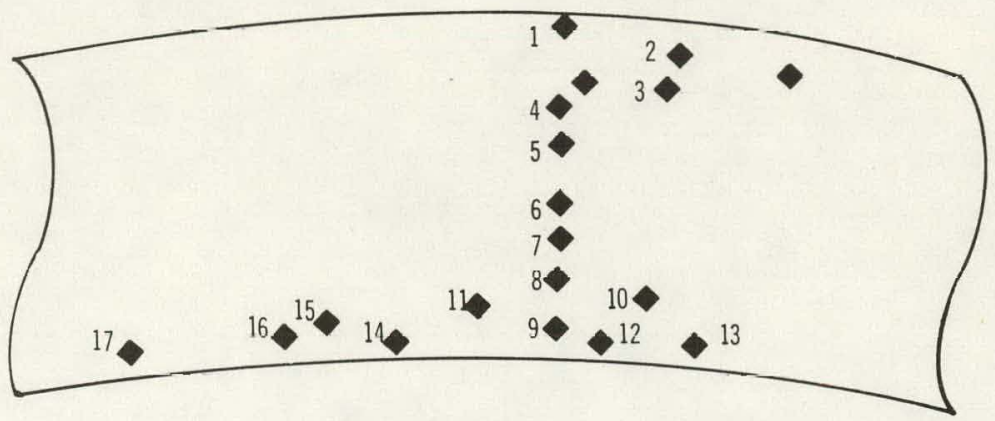

DPH

197

136

162

124

230

222

209

181

222

140

230

151

236*

14

15

16

17
66.5

113.5

101. 0

86.0
0.0218

0.0373

0.0332

0.0282
390 *

133

168

233

182.5 Average

* Not Included in Average 
EPT-6 ROD-D

OTHER ROD SECTIONS 
ROD ELEVATION 3 Inches

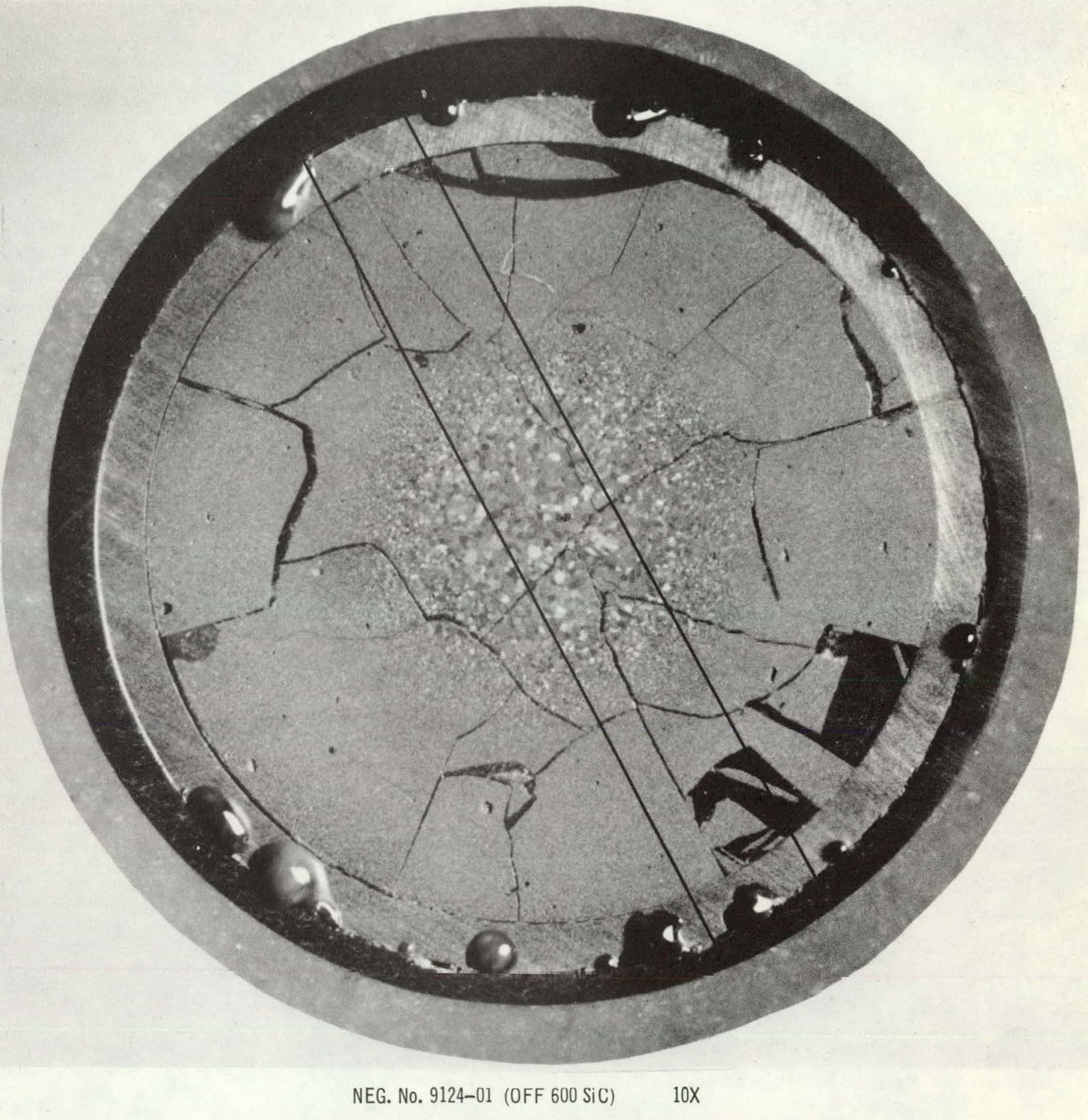

PHOTOMACROGRAPH OF A TRANSVERSE SECTION. 
ROD ELEVATION 3 Inches

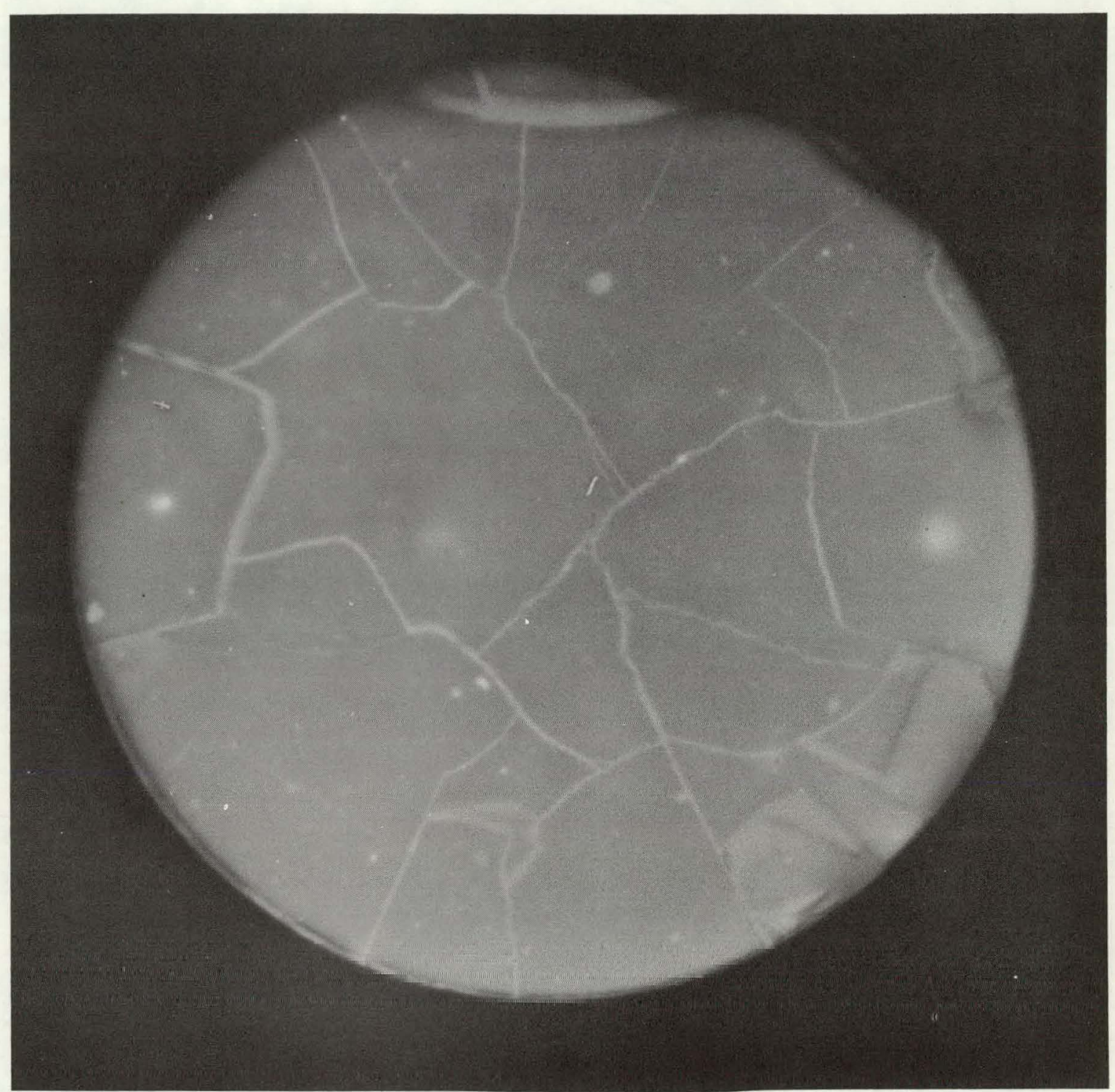

NEG. No. 9124-02

$10 X$

$\beta \cdot \gamma$ AUTORADIOGRAPH OF SAME AREA AS

IN NEG. No. 9124-01; 19 R/min. 70 Min.

EXPOSURE. 


\section{ROD ELEVATION 3 Inches}

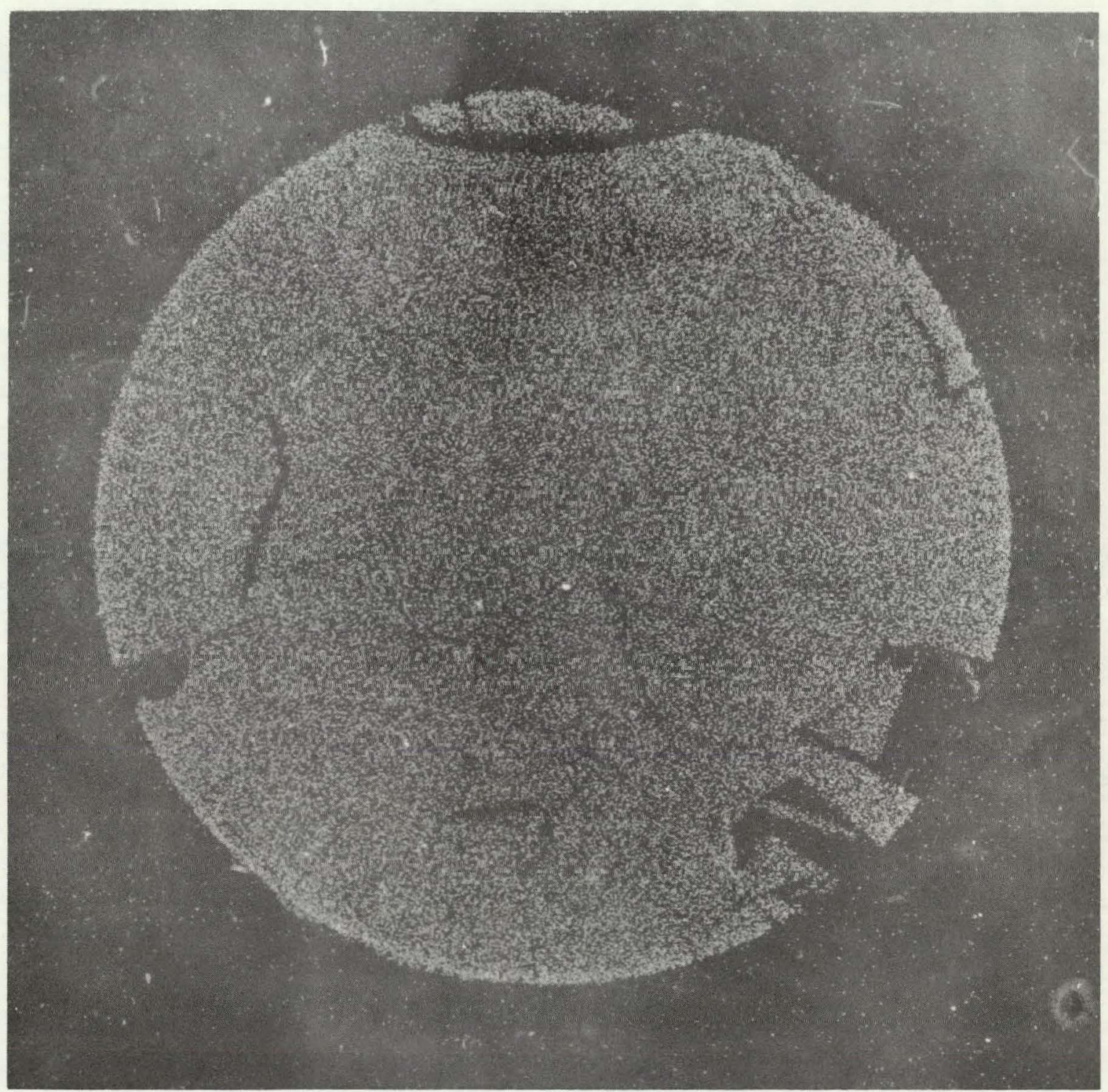

NEG. No. 9124-03

$10 \mathrm{X}$

a AUTORADIOGRAPH OF SAME AREA AS IN NEG. No. 9124-01, $1 \mathrm{~min}$. EXPOSURE. 
ROD ELEVATION 3 Inches

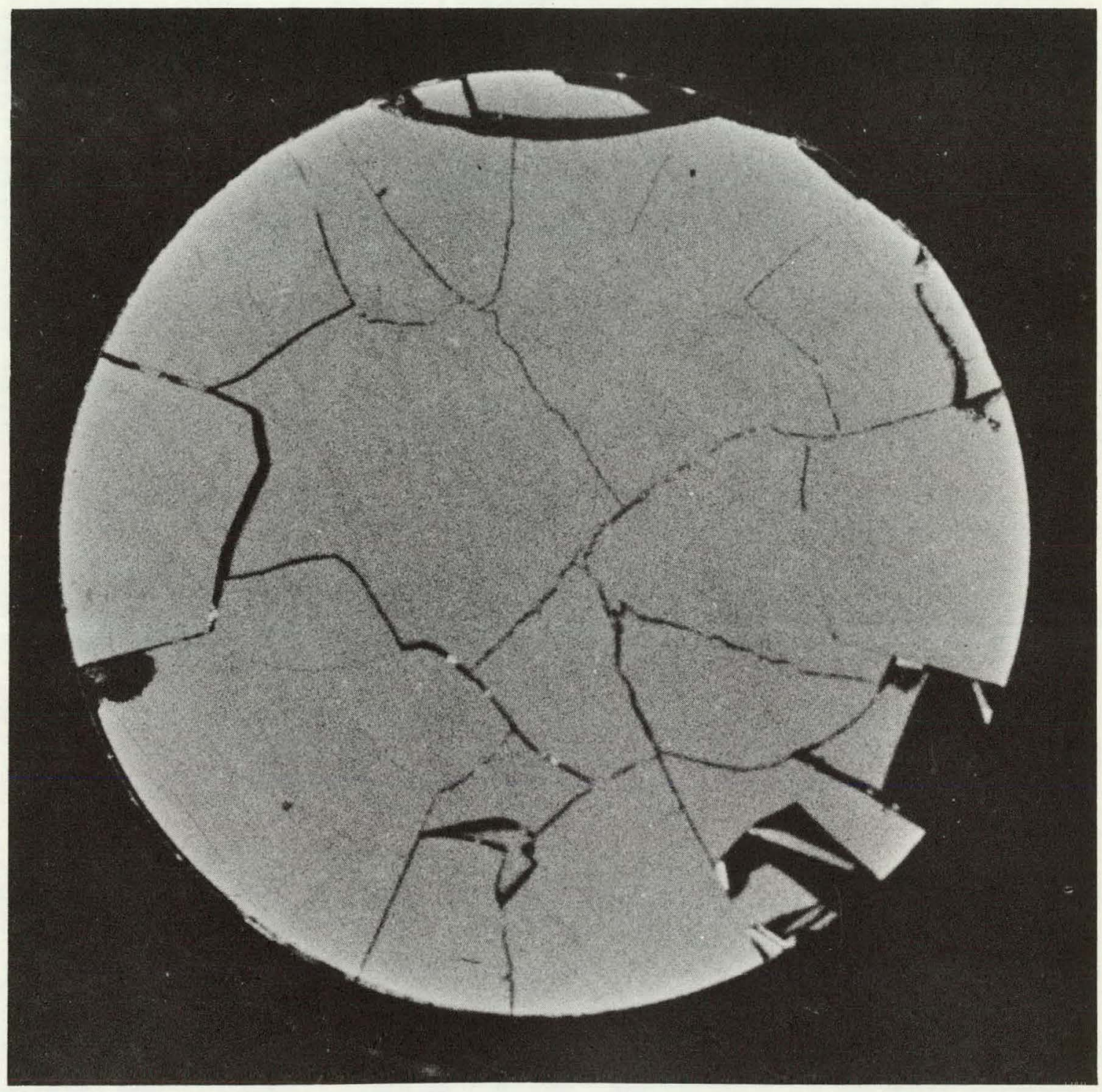

NEG. No. 9124-12

$10 x$

a AUTORADIOGRAPH AS IN NEG. No.

9124-03 WITH 5 MINUTE EXPOSURE.

950 


\section{ROD ELEVATION 3 Inches}

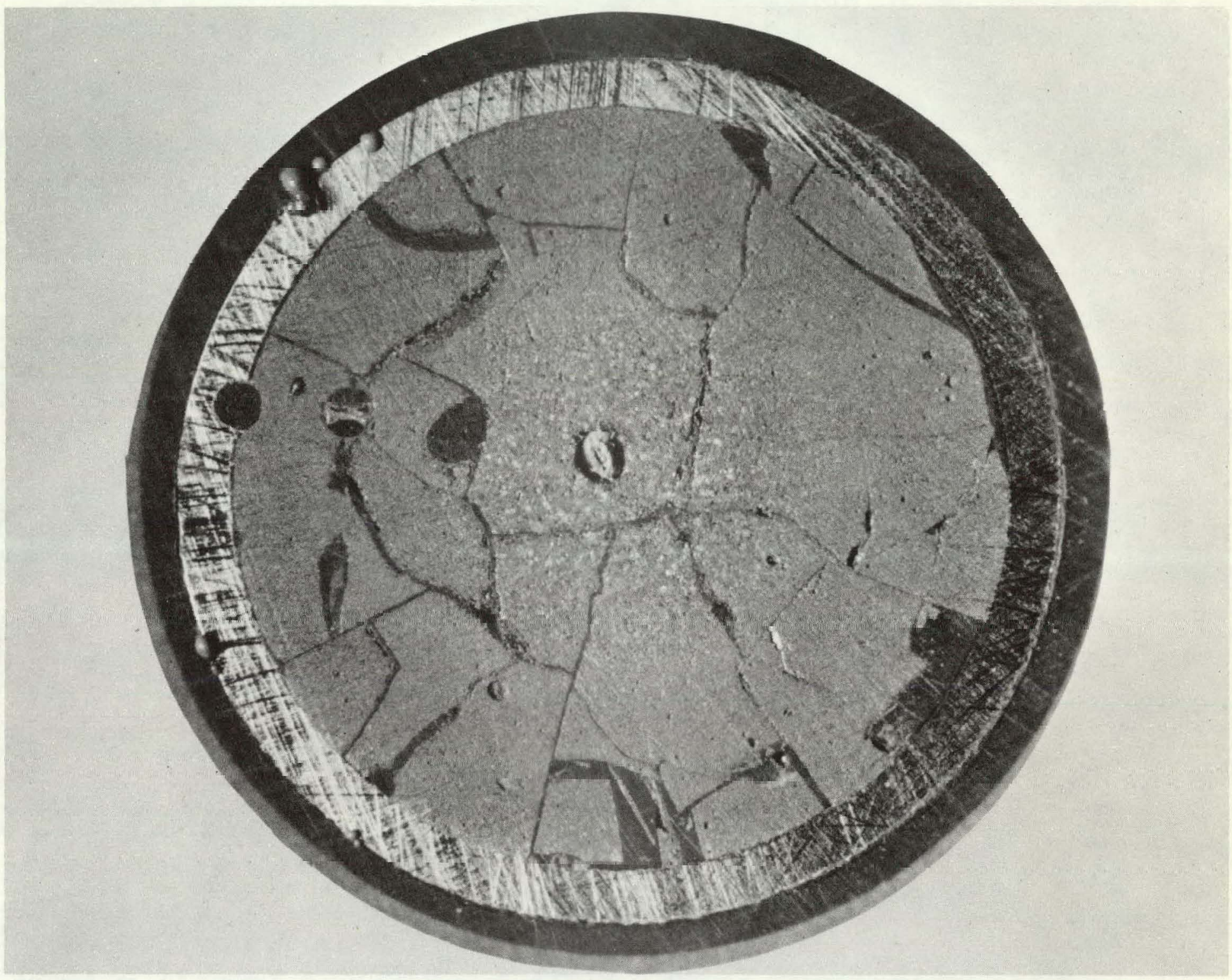

NEG. No. 9124-13 (OFF $600 \mathrm{SiC}$ ) 10X

SAME SECTION AS IN NEG No. 9124-01 AFTER

FURTHER POLISHING AND REMOVAL OF

FISSION PRODUCTS MIGRATION SAMPLES. 

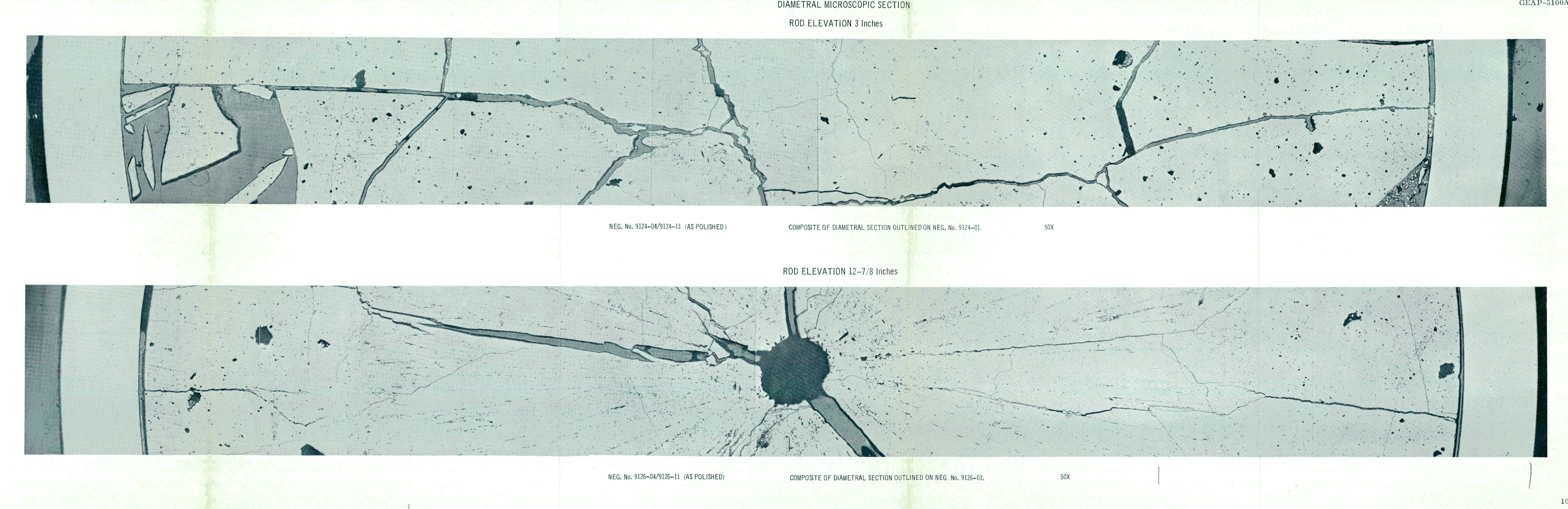
ROD ELEVATION $12-7 / 8$ Inches

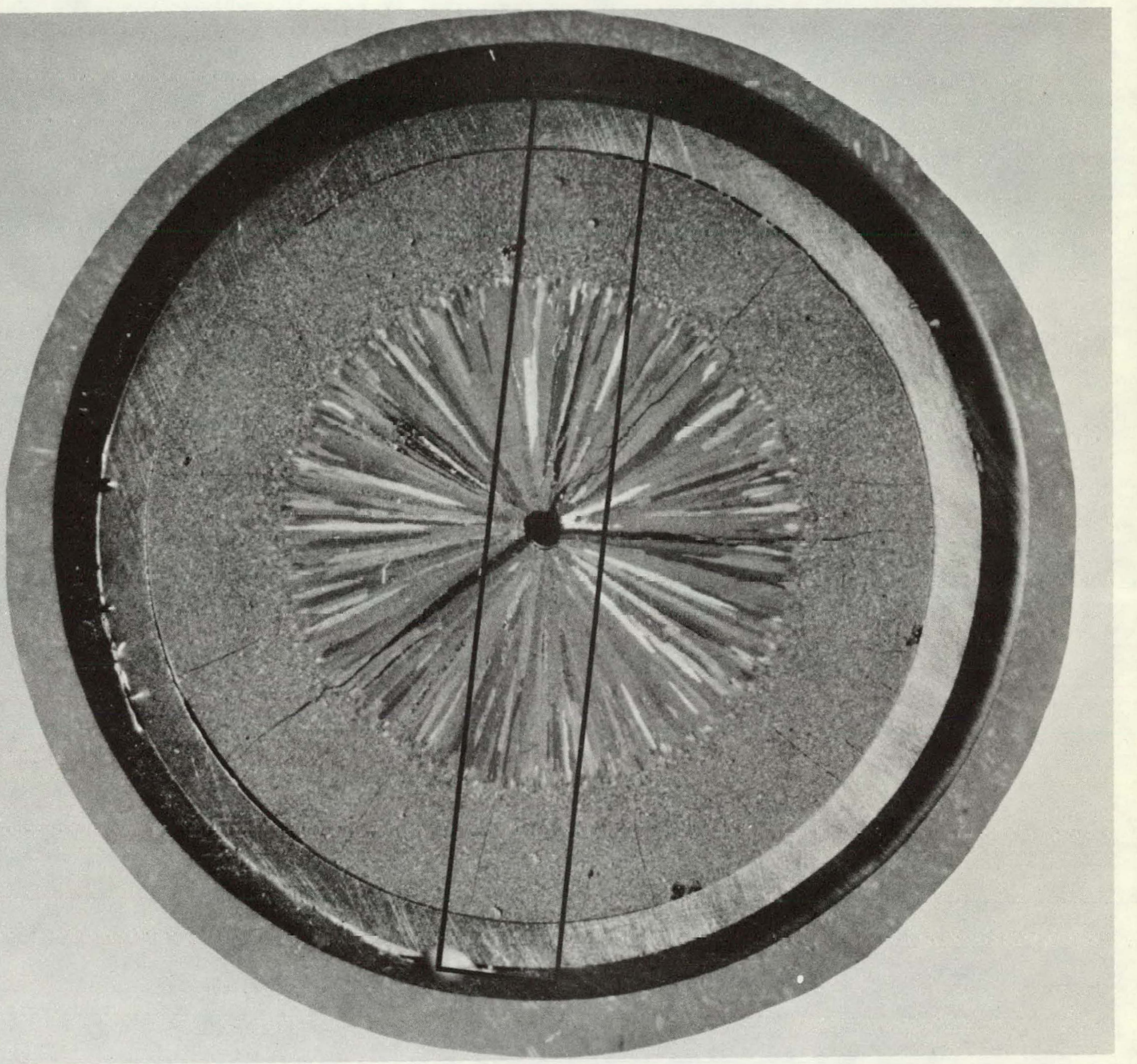

NEG. No. 9126 -01 (OFF $600 \mathrm{SiC}$ )

$10 \mathrm{X}$

PHOTOMACROGRAPH OF A TRANSVERSE SECTION. 


\section{ROD ELEVATION 12-7/8 Inches}

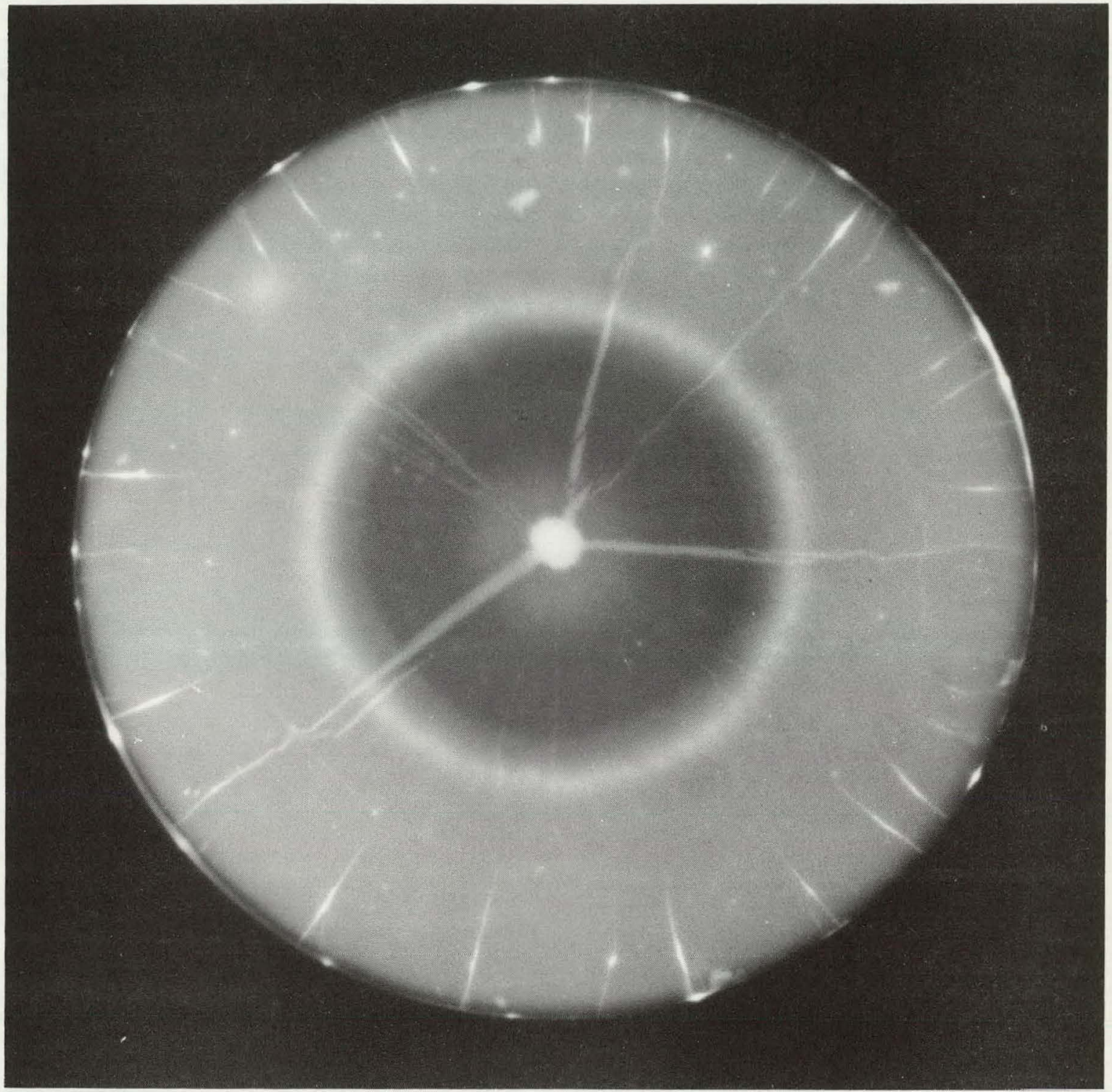

NEG. No. 9126-02

$10 \mathrm{X}$

$\beta \cdot \boldsymbol{r}$ AUTORADIOGRAPH OF SAME AREA AS IN NEG. No. 9126-01; 34 R/min. FOR 38 MINUTE EXPOSURE. 
ROD ELEVATION 12-7/8 Inches

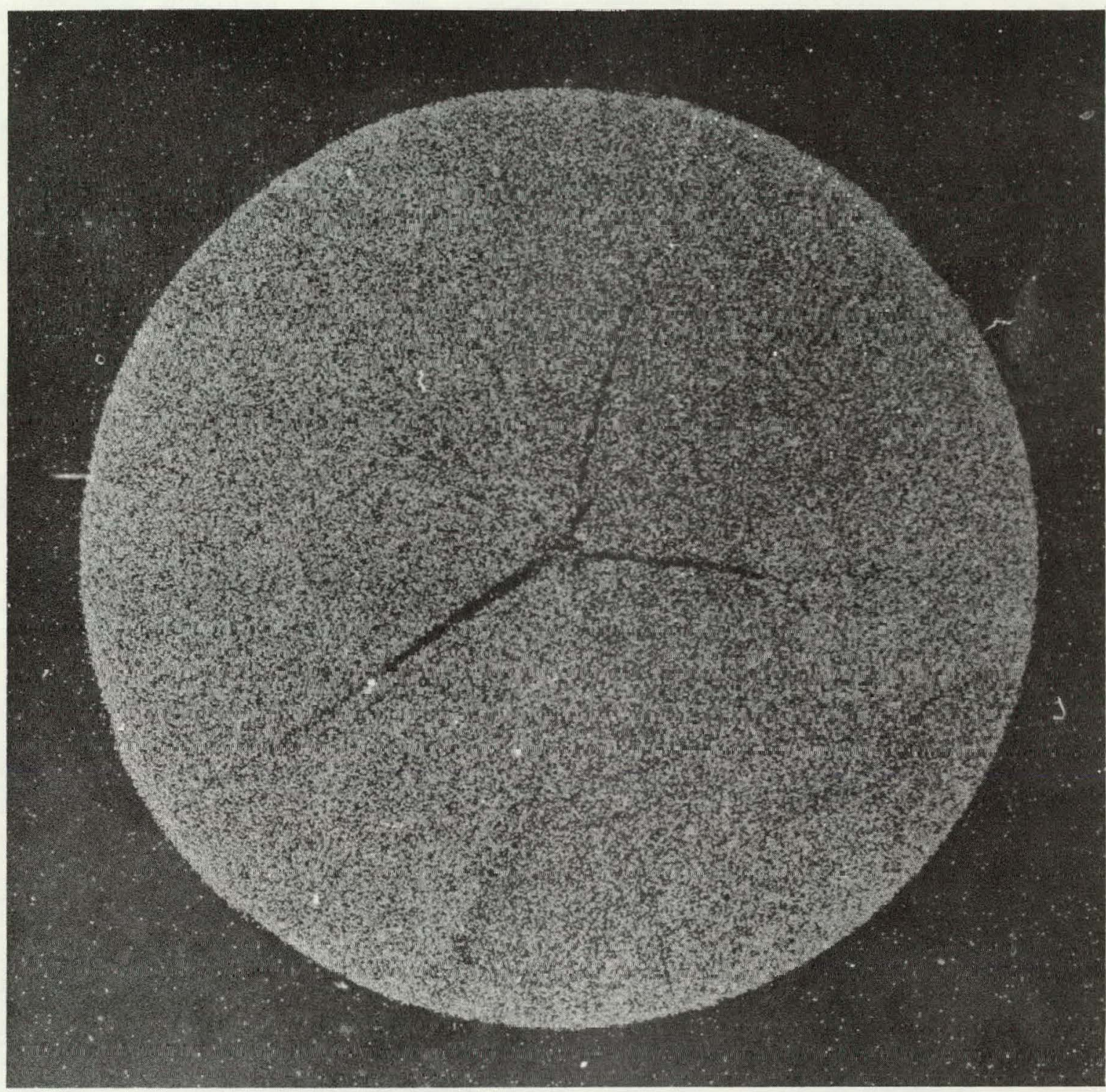

NEG. No. 9126-03

$10 \mathrm{X}$

a AUTORADIOGRAPH OF SAME AREA AS IN

NEG. No. 9126-01; 1 MINUTE EXPOSURE 
ROD ELEVATION 12-7/8 Inches

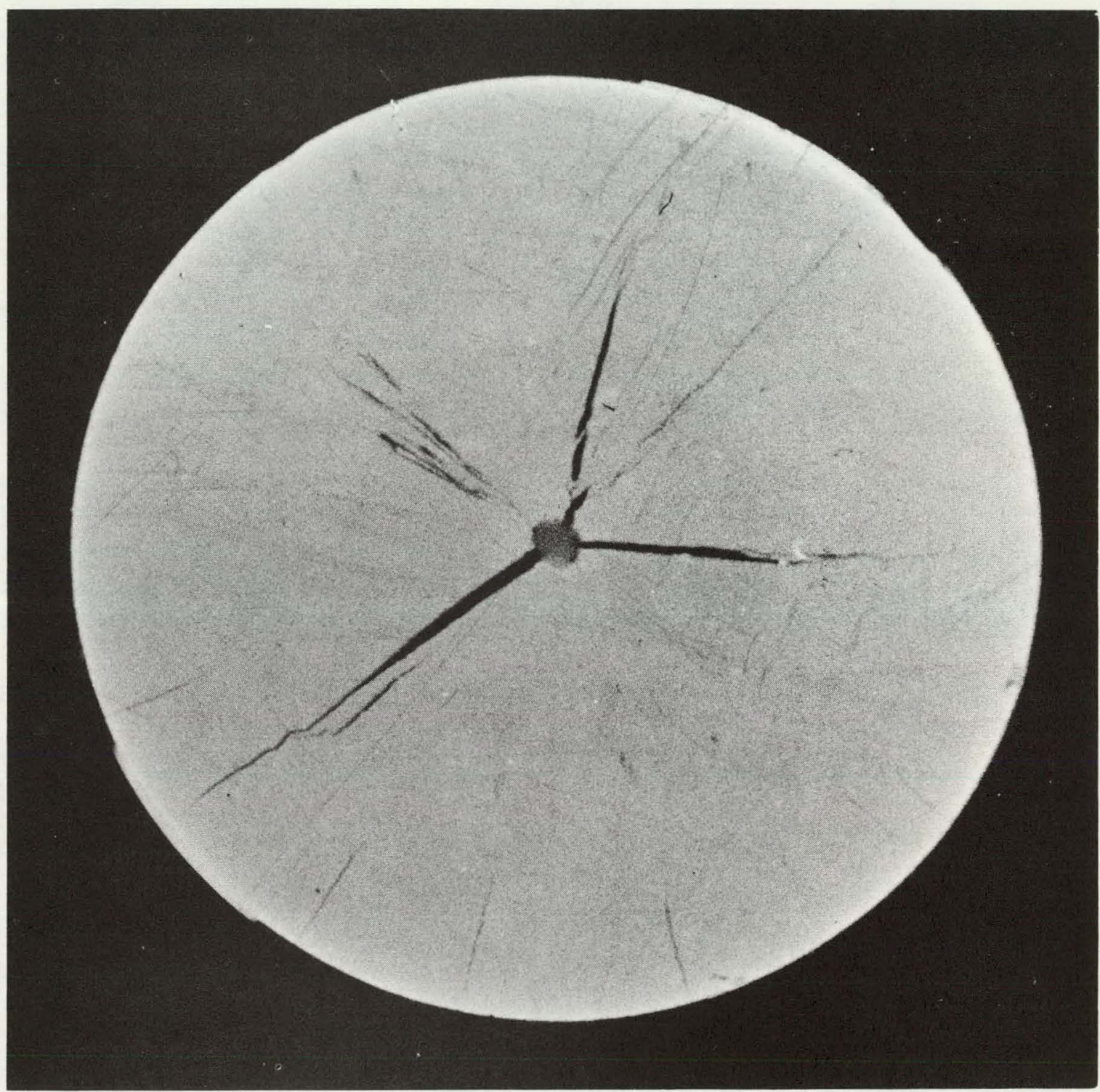

NEG. No. $9126-12$

$10 \mathrm{X}$

a AUTORADIOGRAPH LIKE NEG. No. 9126-03

BUT WITH 5 MINUIE EXPOSURE 


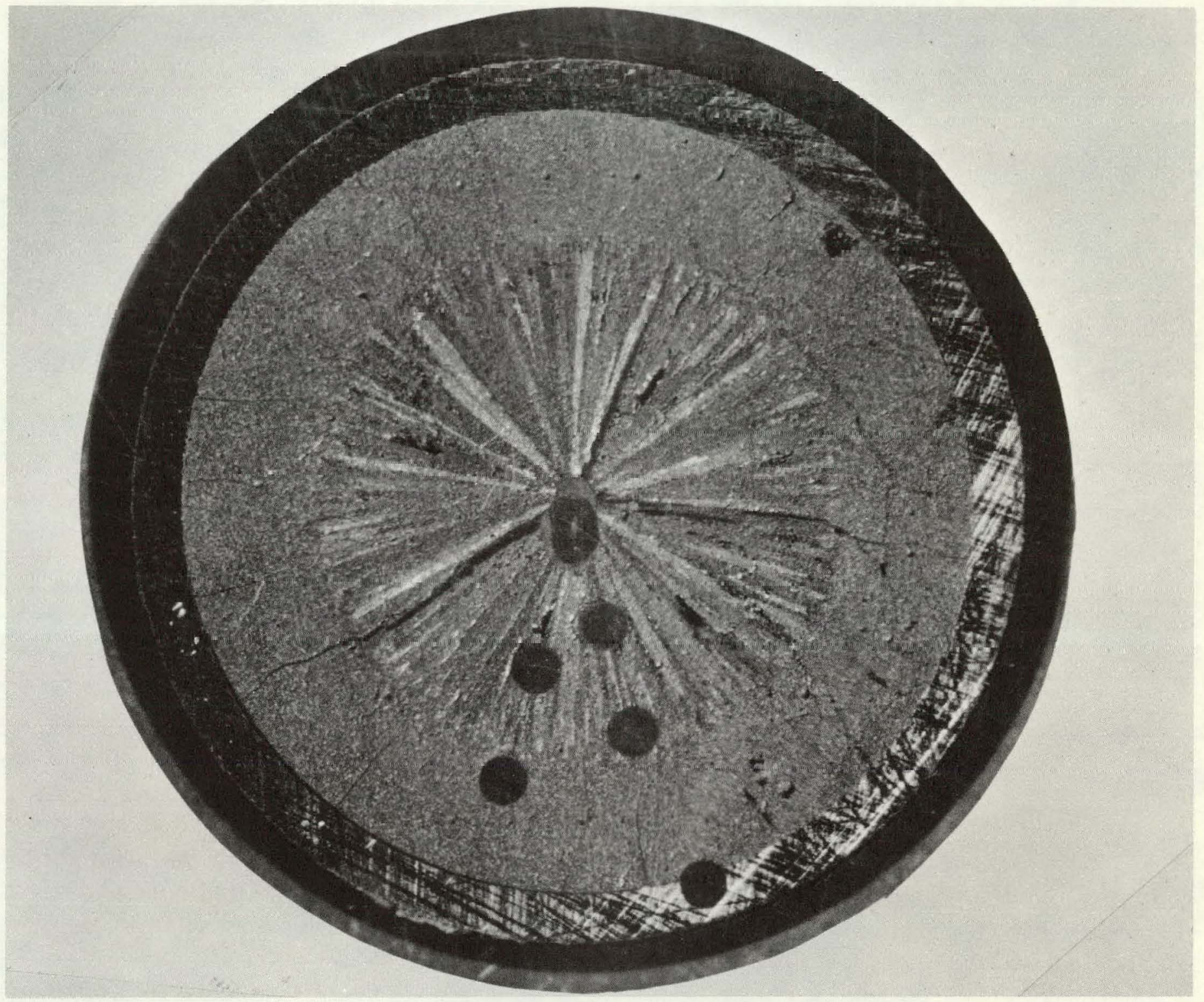

NEG. No. 9126-13

SAME SECTION AS IN NEG. No. 9126-01 AFTER

FURTHER POLISHING AND REMOVAL OF

FISSION PRODUCTS MIGRATION SAMPLES. 
ROD ELEVATION 171/4/4 Inches

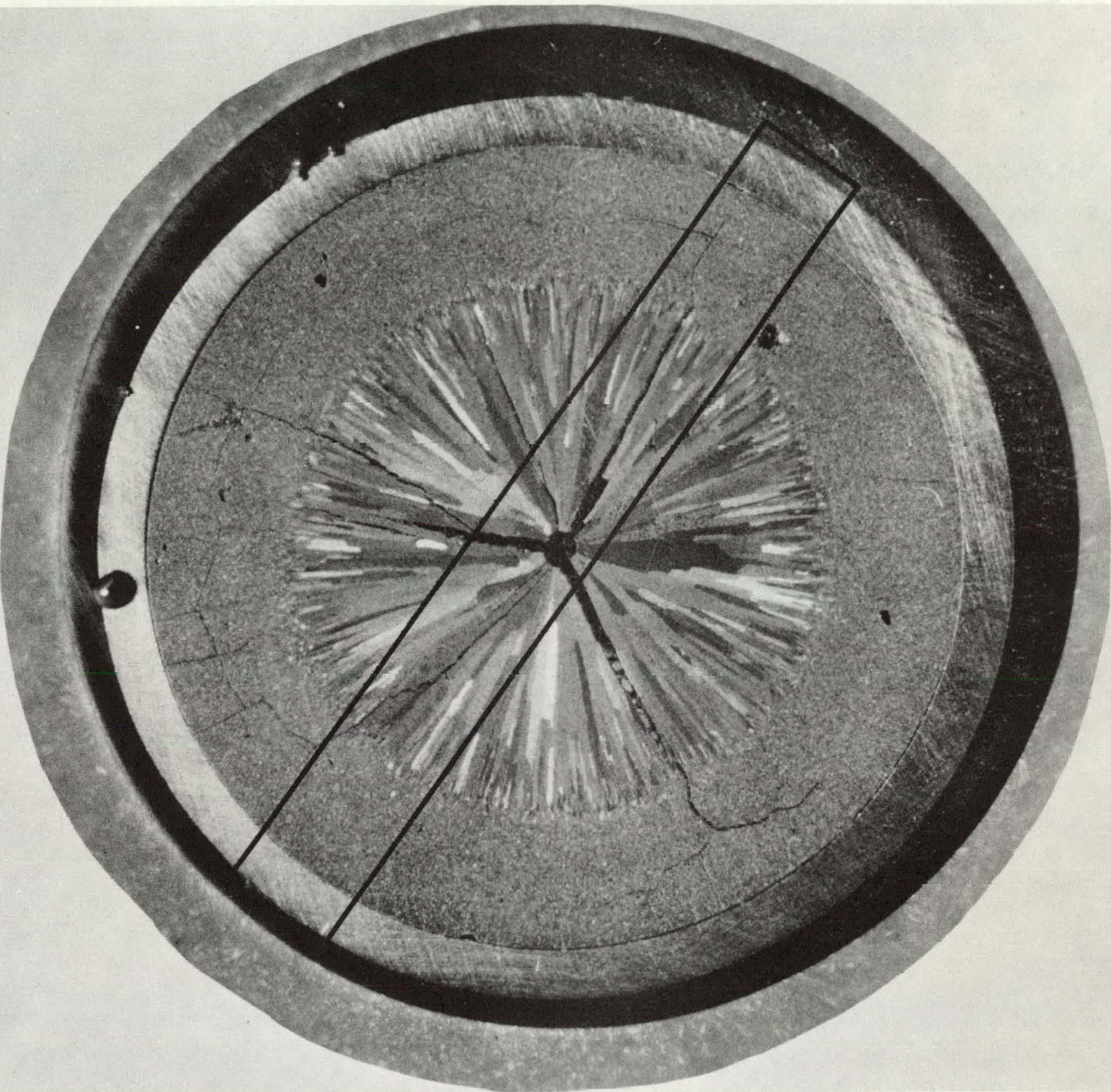

NEG. NO. YILI-UL

10X

PHOTOMACROGRAPH OF A TRANSVERSE SECTION. 
ROD ELEVATION 17\%1/4 Inches

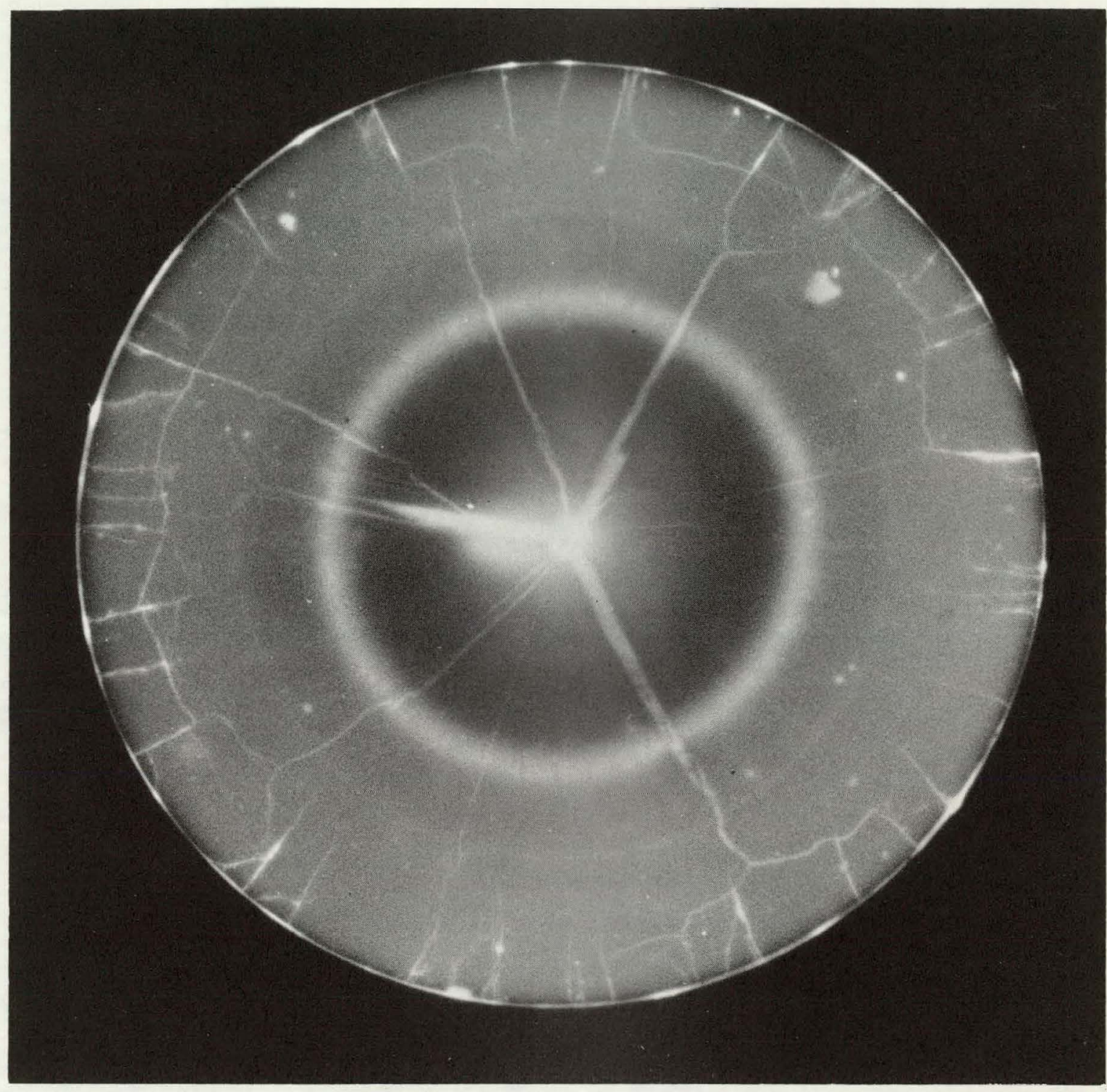

NEG. №. 9127-02

$10 X$

$\beta-\gamma$ AUTORADIOGRAPH OF SAME SECTION AS

IN NEG. No. 9127-01, 38 R/Min. FOR

33.5 IN EXPOSURE.

950 


\section{ROD ELEVATION 171/4 Inches}

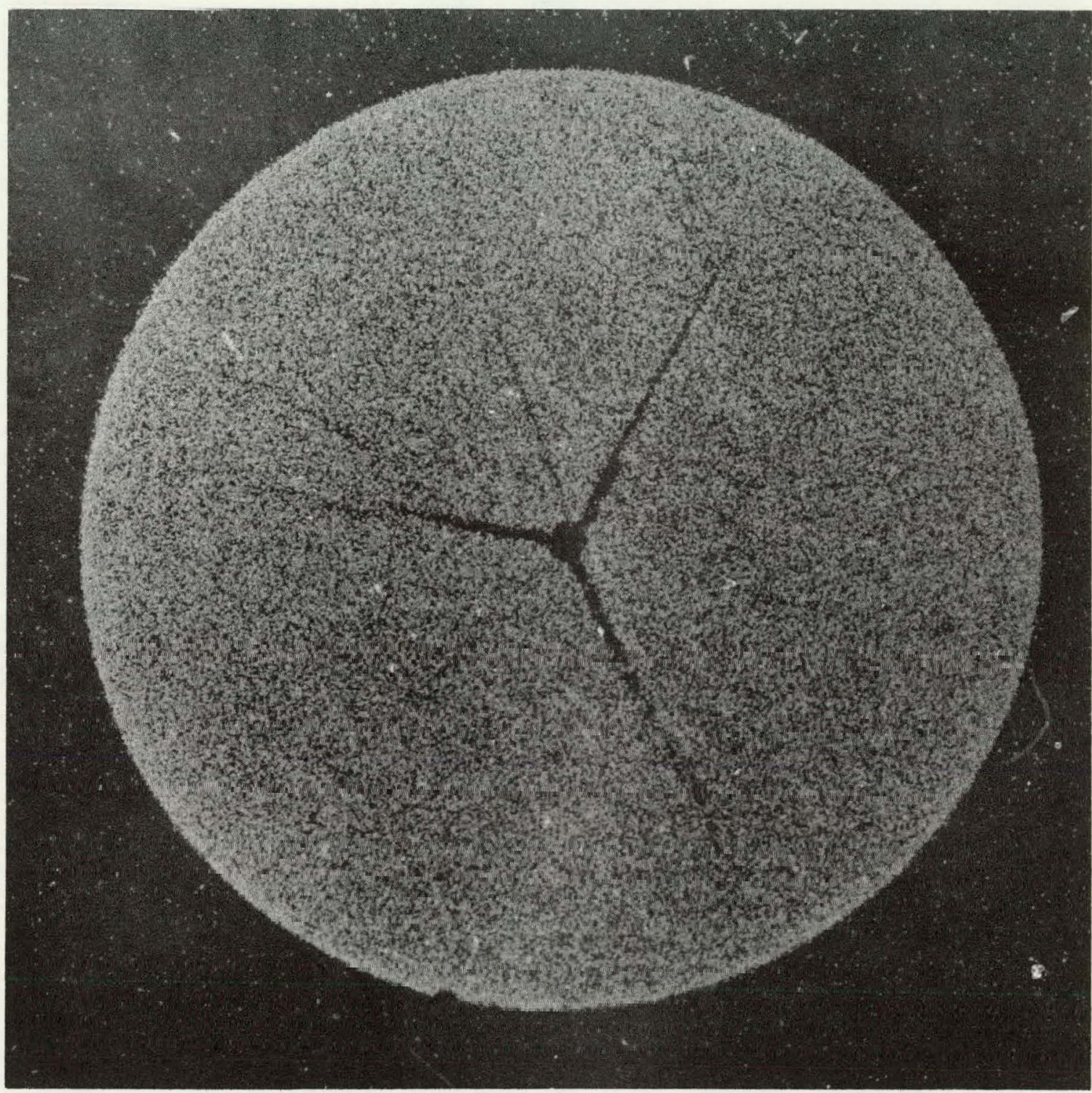

NEG. No. 9127-03

$10 \mathrm{X}$

a AUTORADIOGRAPH OF SAME AREA AS

IN NEG. No. 9127 -01, 1 MINUTE EXPOSURE. 
ROD ELEVATION 17\%1/4 Inches

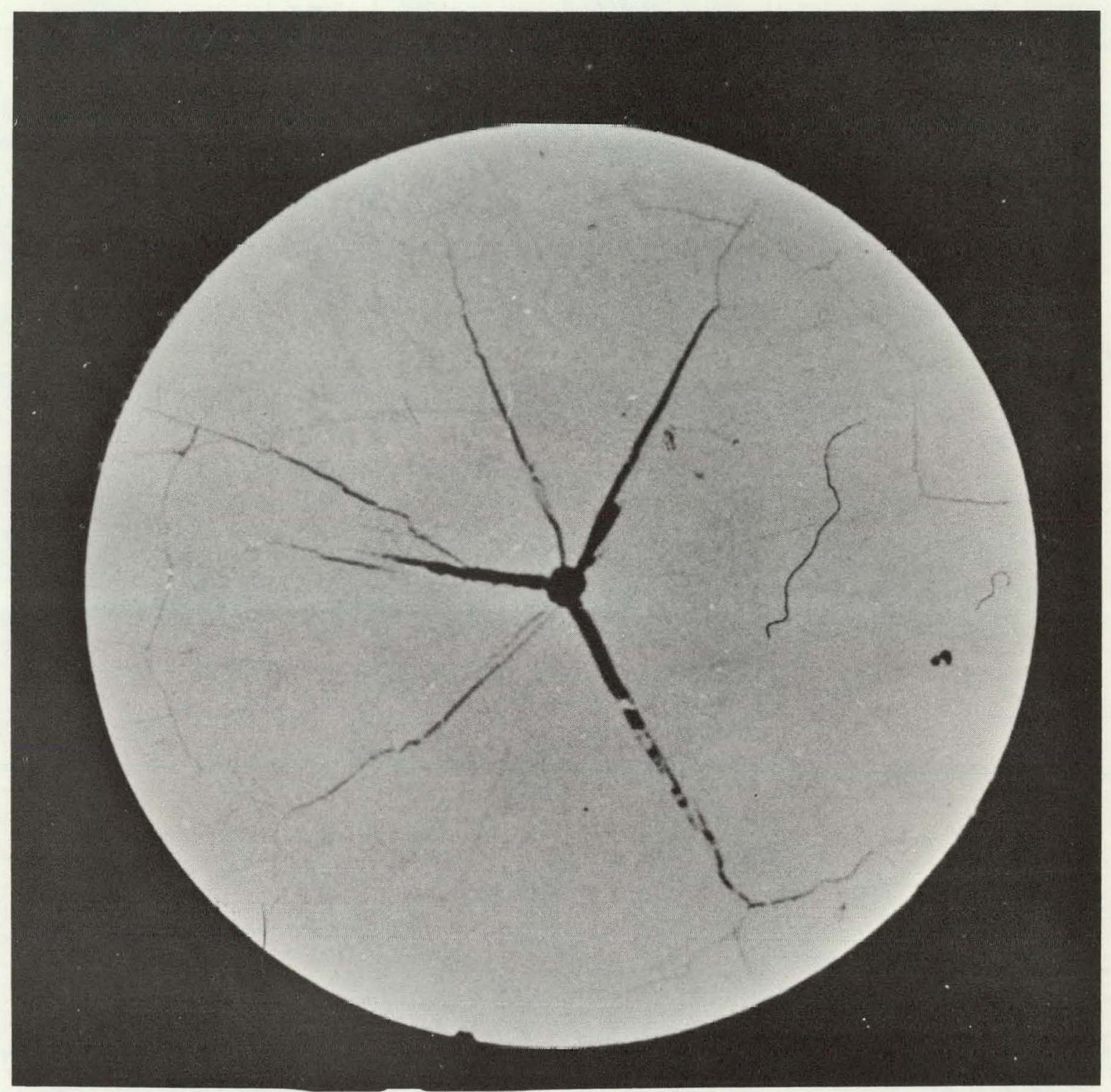

NEG. No. 9127-13

$10 \mathrm{X}$

a AUTORADIOGRAPH AS IN NEG. No.

9127-03 WITH 5 MINUTE EXPOSURE 
ROD ELEVATION 171/4 Inches

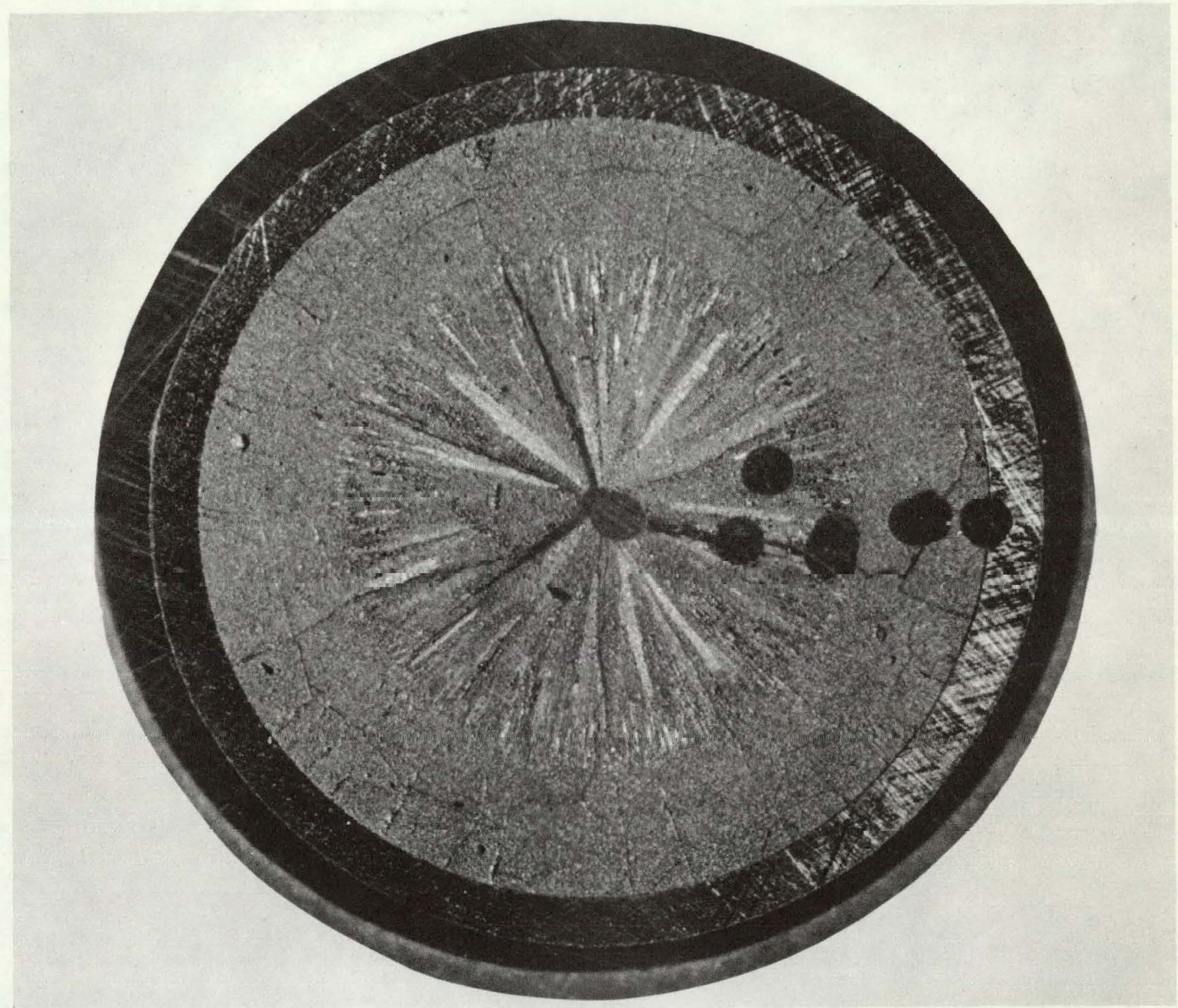

NEG. No. 9127-14

10X

PHOTOMACROGRAPH OF SAME SECTION

AS IN NEG. No. 9127-01 AFTER FURTHER

POLISHING AND REMOVAL OF FISSION

PRODUCTS MIGRATION SAMPLES. 


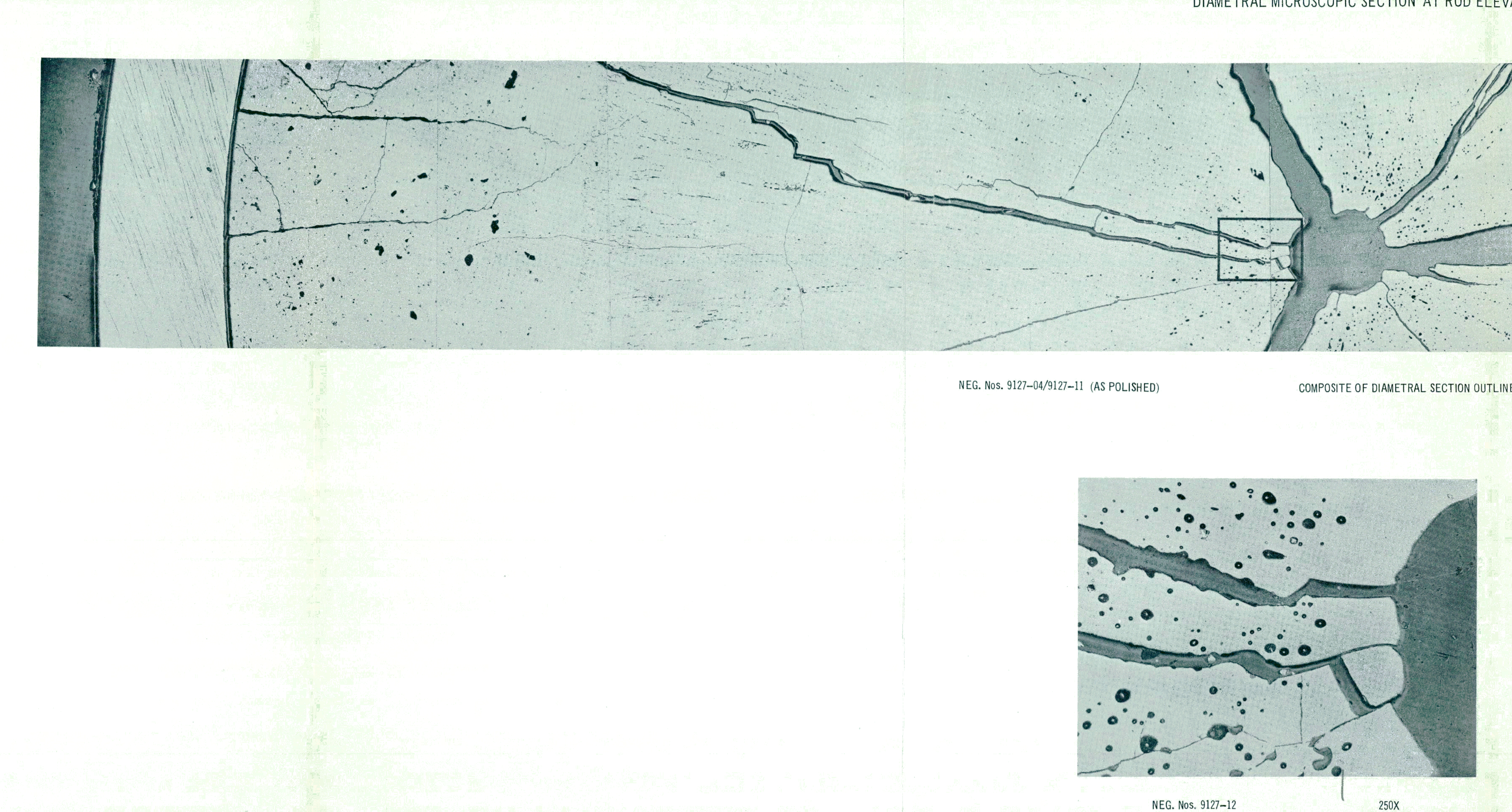


ROD ELEVATION 221/4/4nches

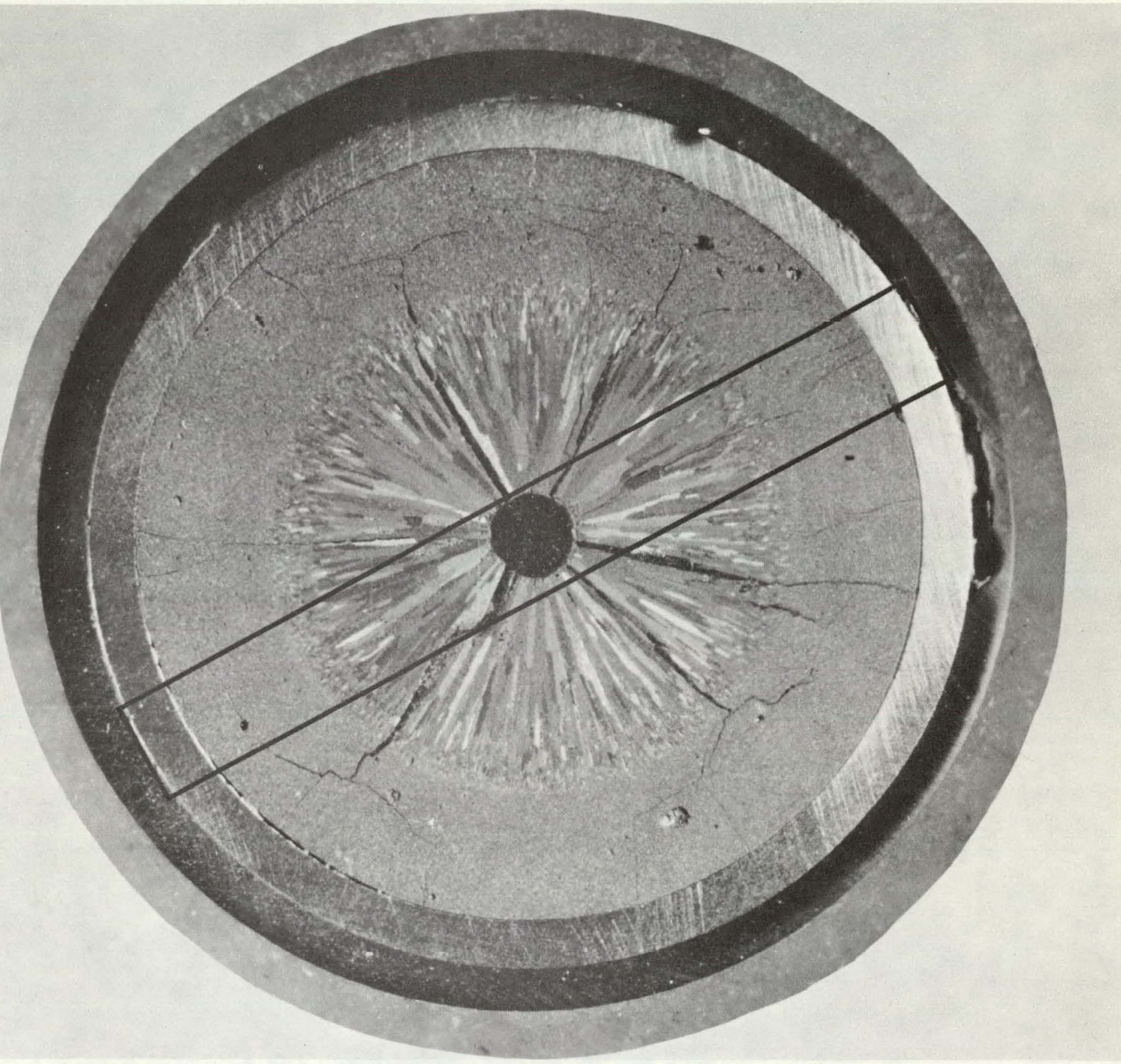

NEG. No. 9125-01 (OFF $600 \mathrm{SiC}$ )

$10 X$

PHOTOMACROGRAPH OF A TRANSVERSE SECTION 
ROD ELEVATION 221/4 Inches

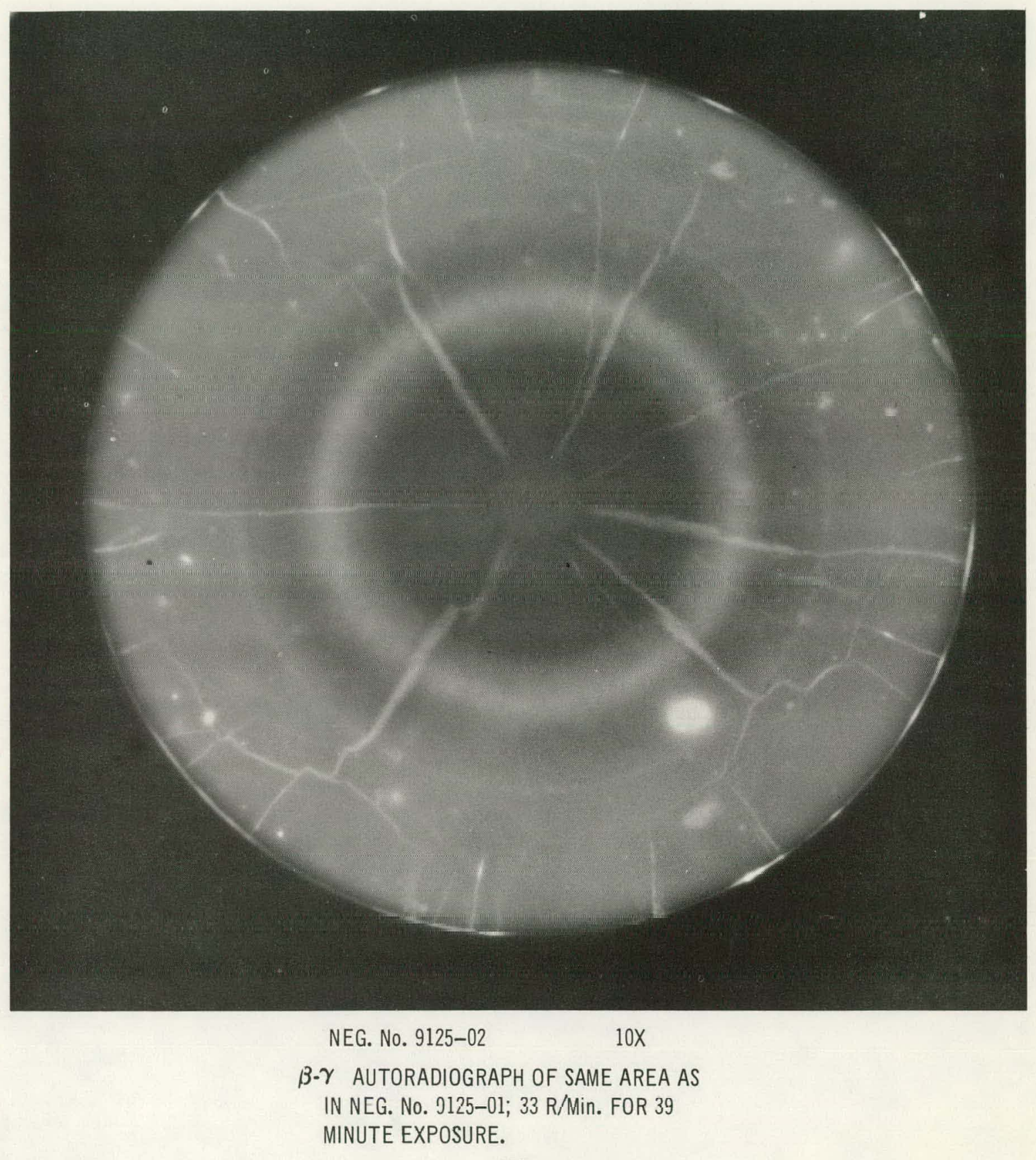




\section{ROD ELEVATION 221/4 Inches}

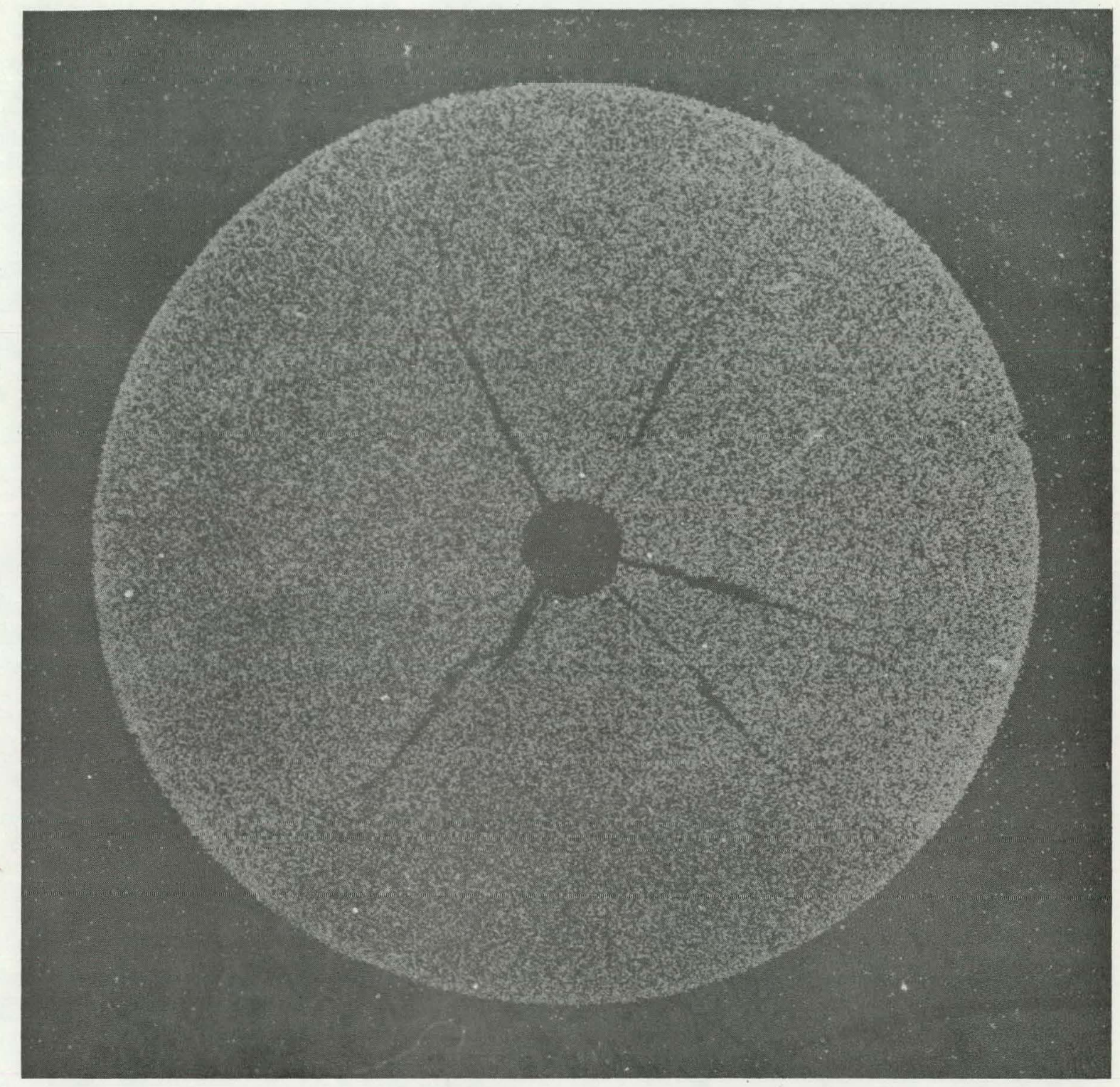

NEG. No. 9125-03

$10 \mathrm{X}$

$\alpha$ AUTORADIOGRAPH OF SAME AREA AS

IN NEG. No. 9125-01, 1 MINUTE EXPOSURE

950 
GEAP-5100A

ROD ELEVATION 221\% Inches

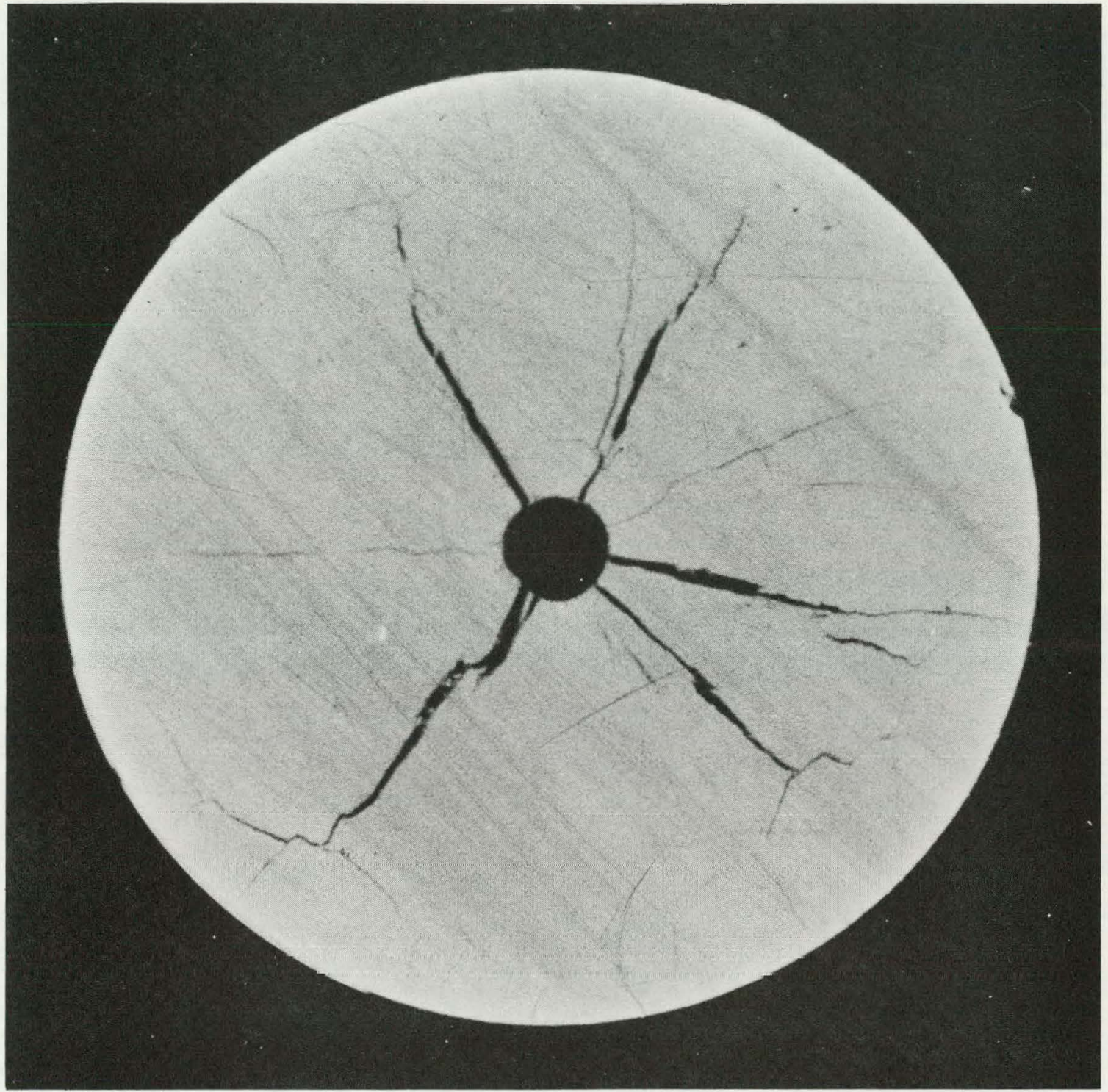

NEG. No. 9125-14 10X

a AUTORADIOGRAPH AS IN NEG. No, 9125-13

WITH 5 MINUTE EXPOSURE. 


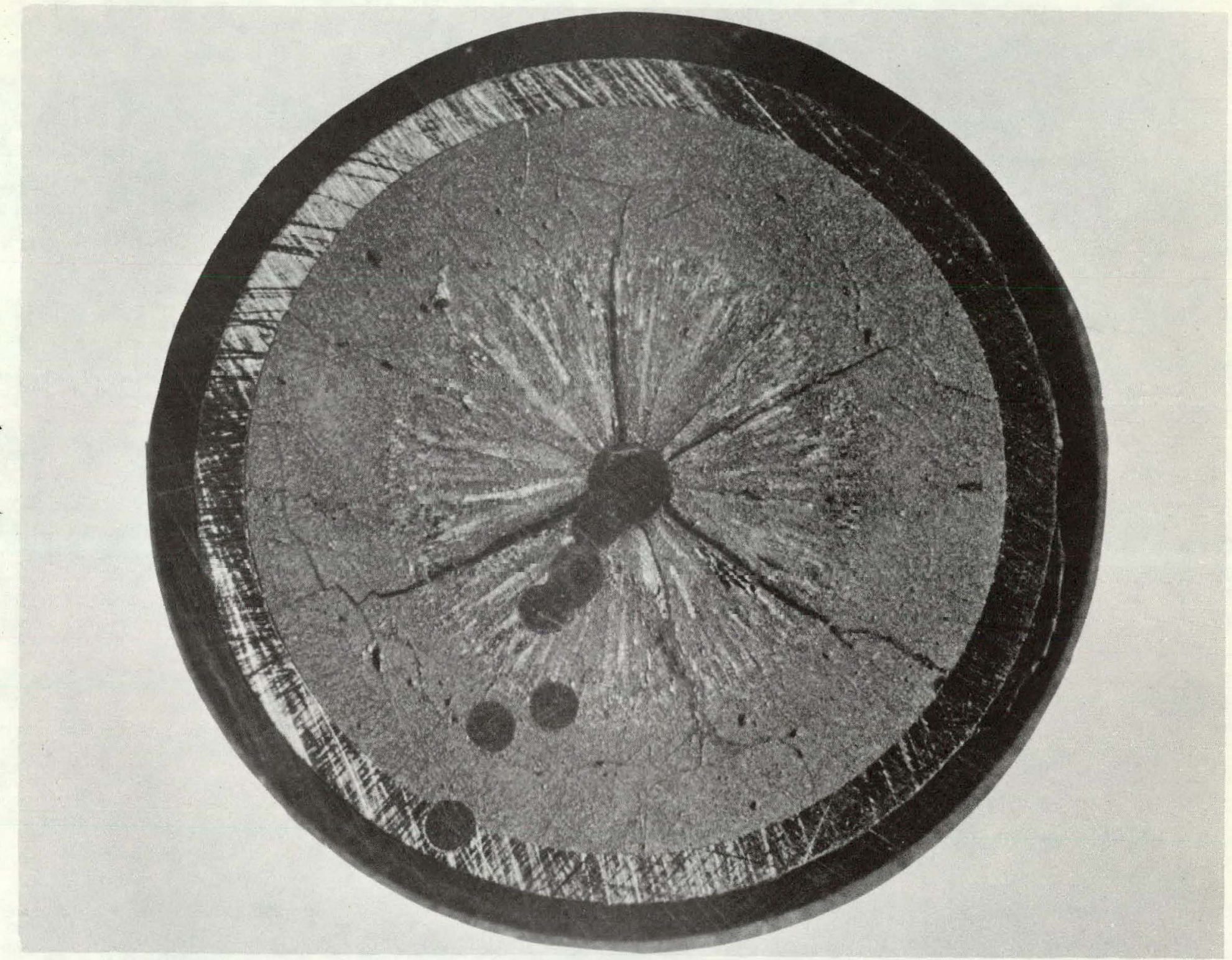

NEG. No. $9125-14$

$10 x$

SAME SECTION AS IN NEG. No. 9125-01 AFTER

FURTHER POLISHING AND REMOVAL OF

FISSION PRODUCTS MIGRATION SAMPLES. 

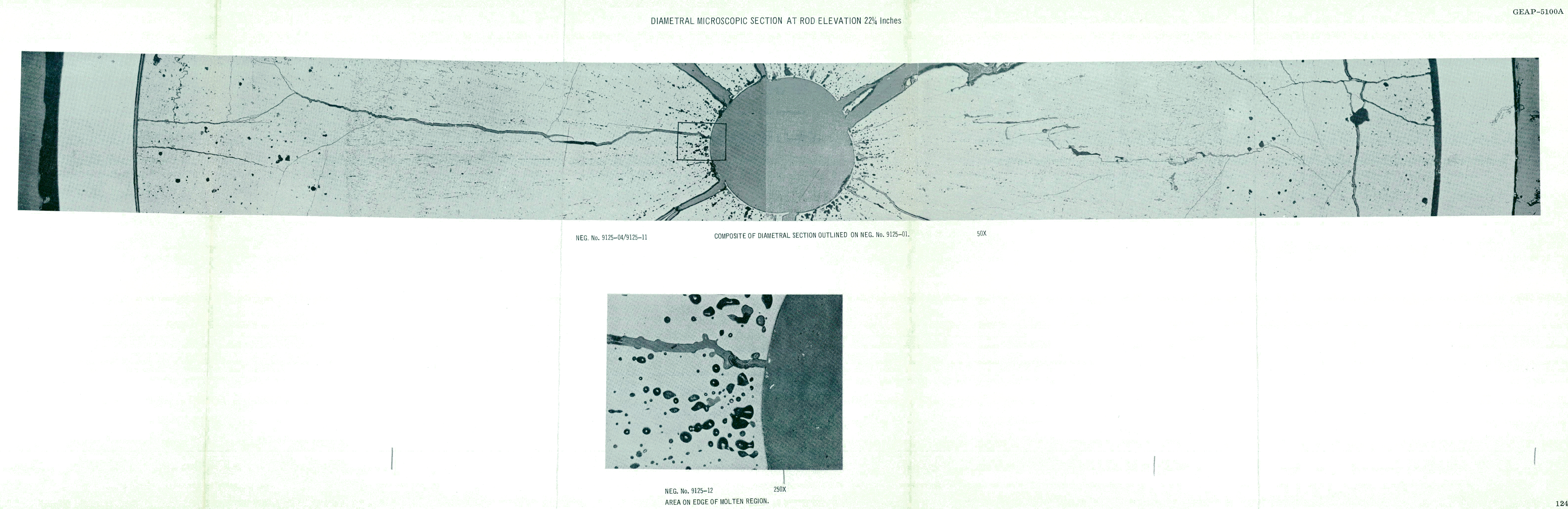
ROD ELEVATION 31-7/8 Inches

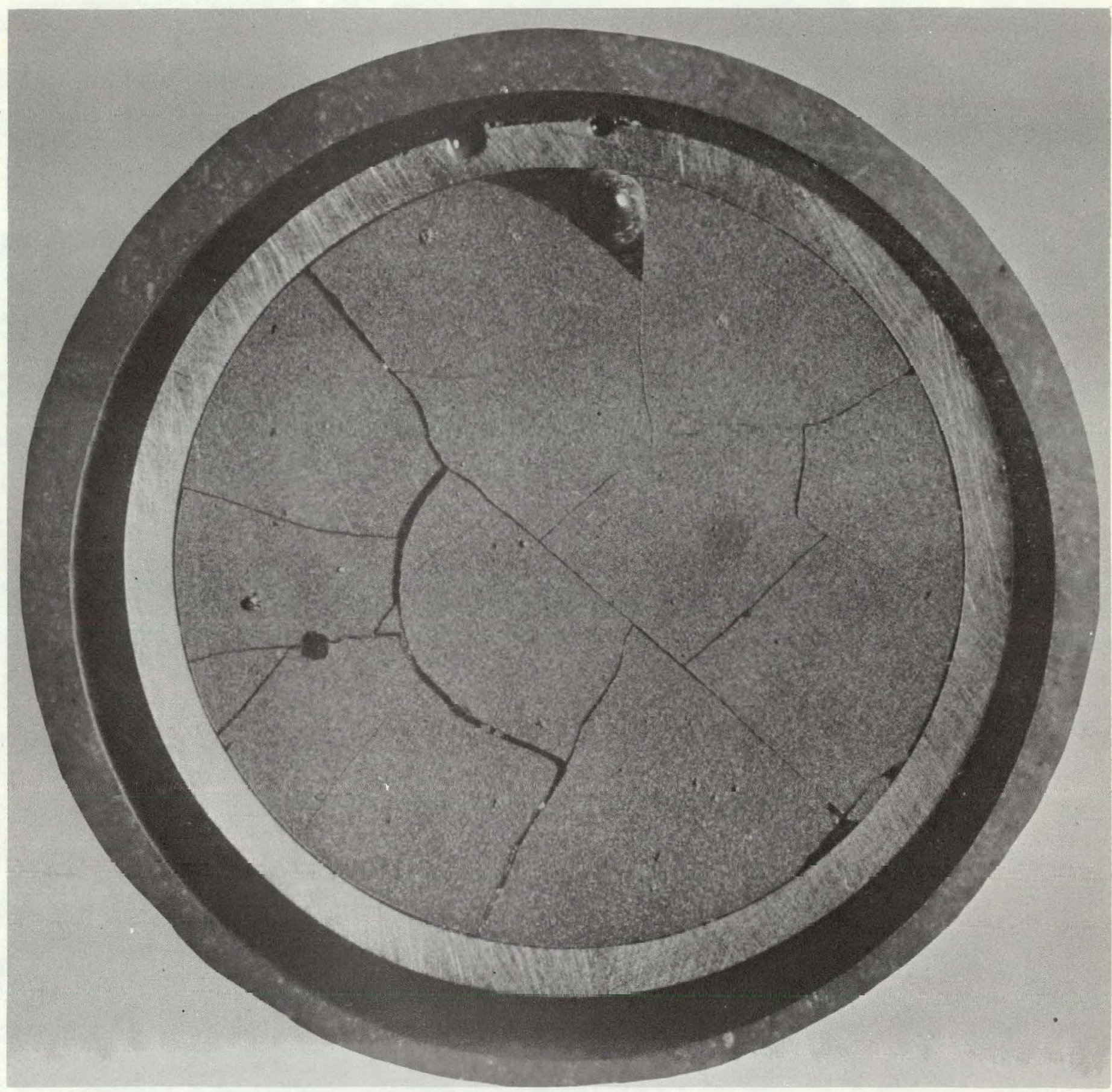

NEG. No. 9128-01 (UFF $600 \mathrm{SiC}$ )

$10 \mathrm{X}$

PHOTOMACROGRAPH OF A TRANSVERSE SECTION 


\section{ROD ELEVATION 31-7/8 Inches}

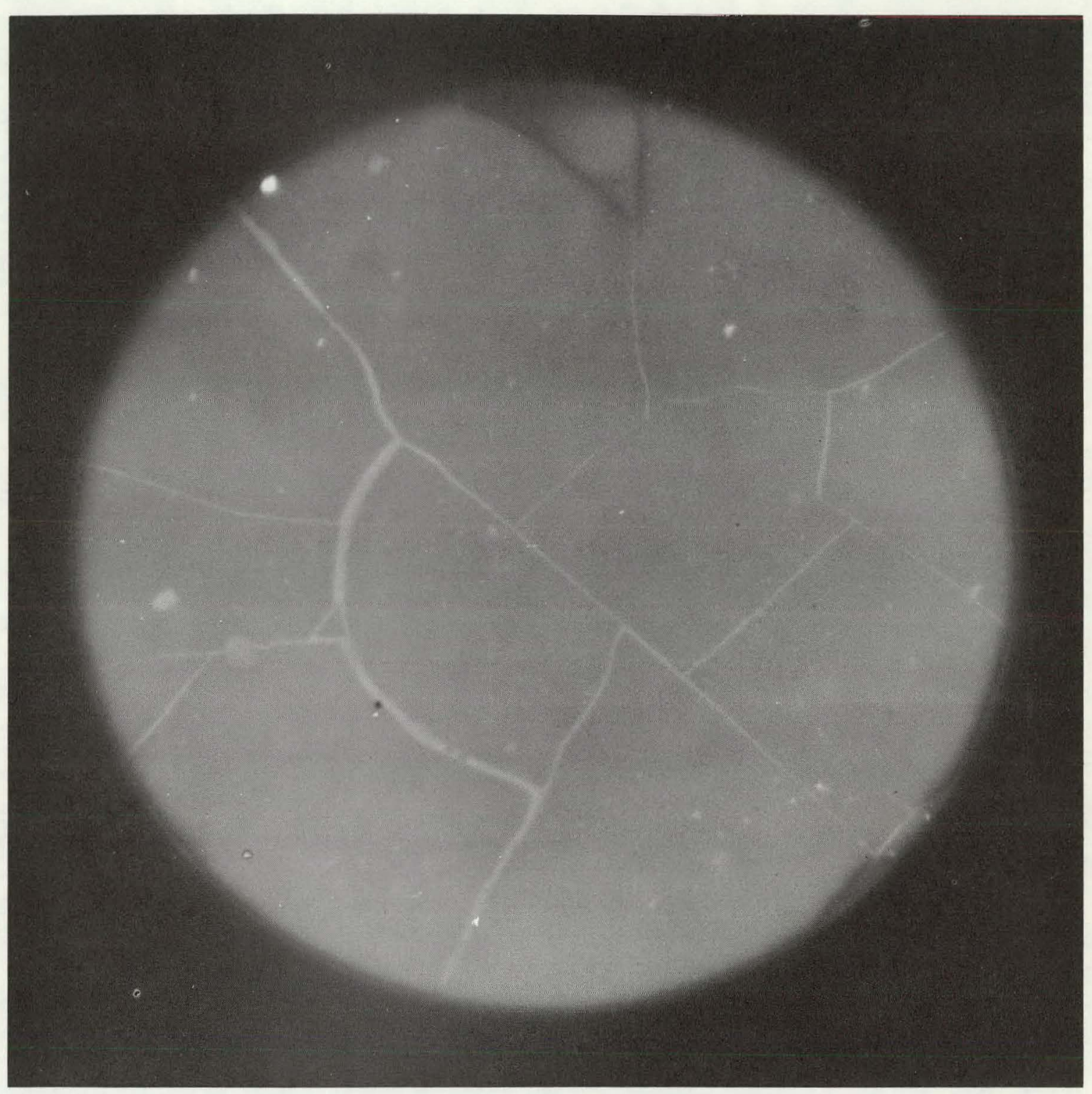

NEG. No. 9128-02

$10 \mathrm{X}$

$\beta-\gamma$ AUTORADIOGRAPH OF SAME AREA AS IN NEG. No. 9128-01; 9 R/Min. FOR 150 MINUTE EXPOSURE. 
GEAP-5100A

\section{ROD ELEVATION 31-7/8 Inches}

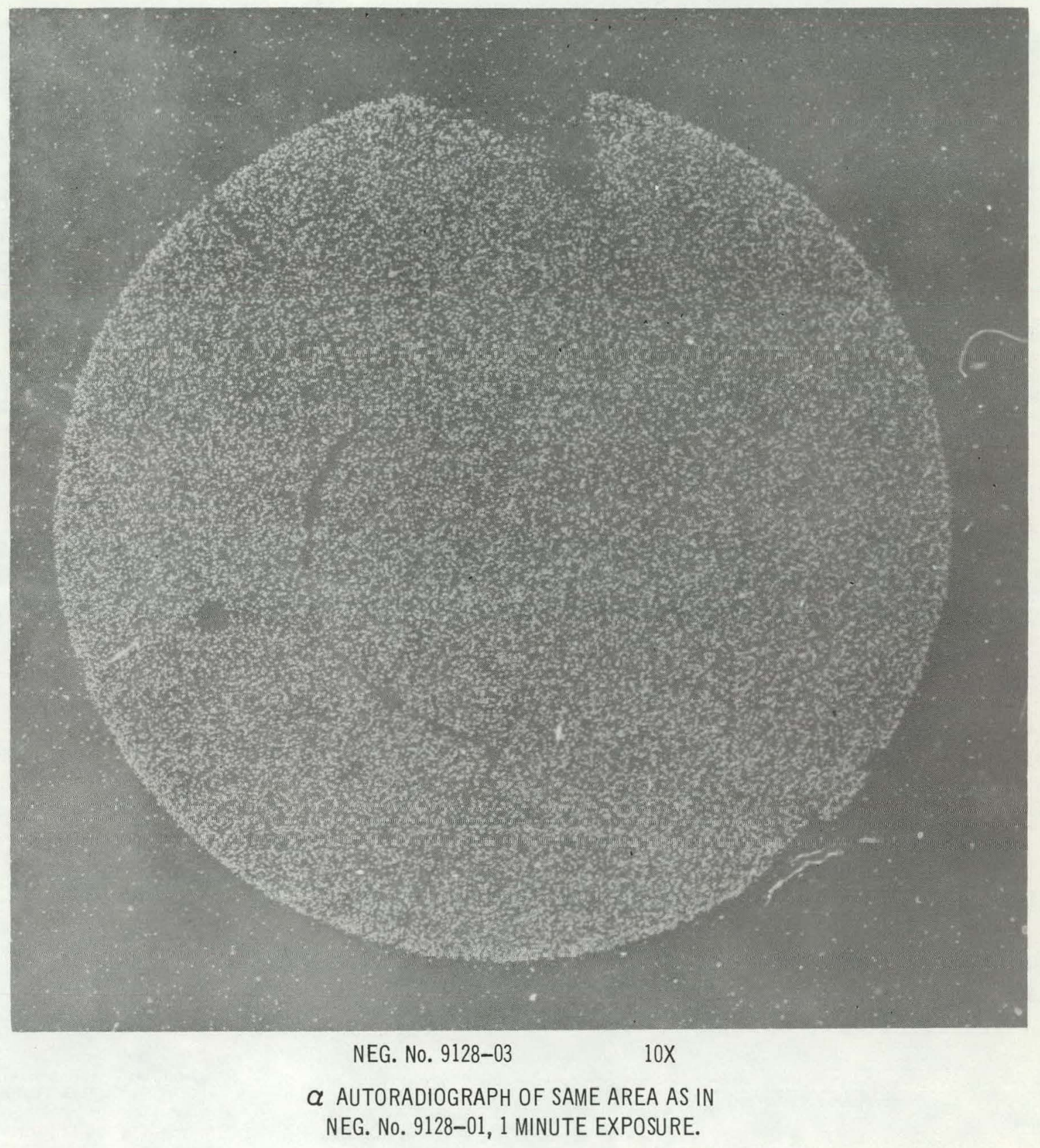


ROD ELEVATION 31-7/8 Inches

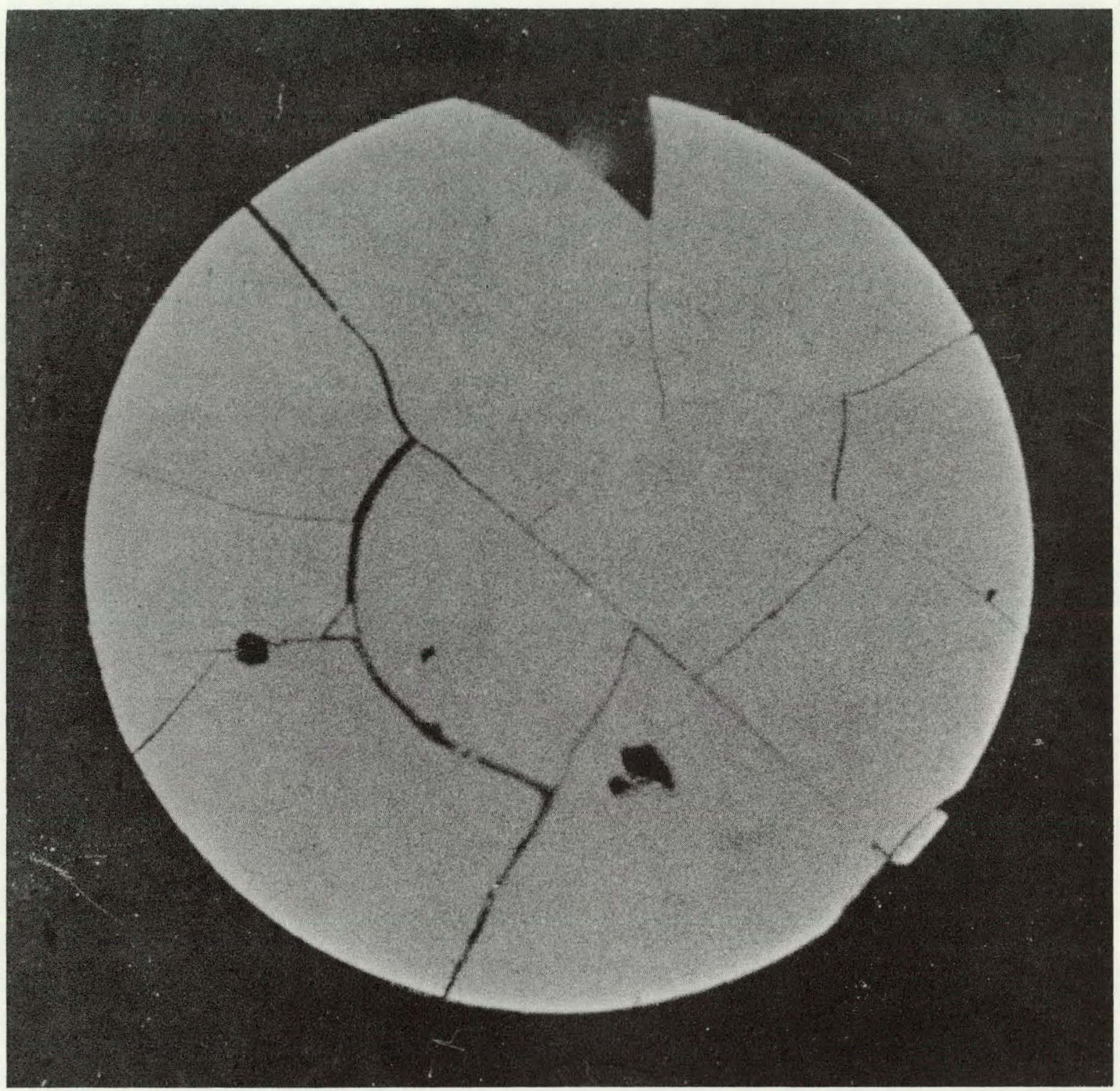

NEG. No. 9128-04

$10 \mathrm{X}$

a AUTORADIOGRAPH AS IN NEG. No. 9128-03

WITH 5 MINUTE EXPOSURE 


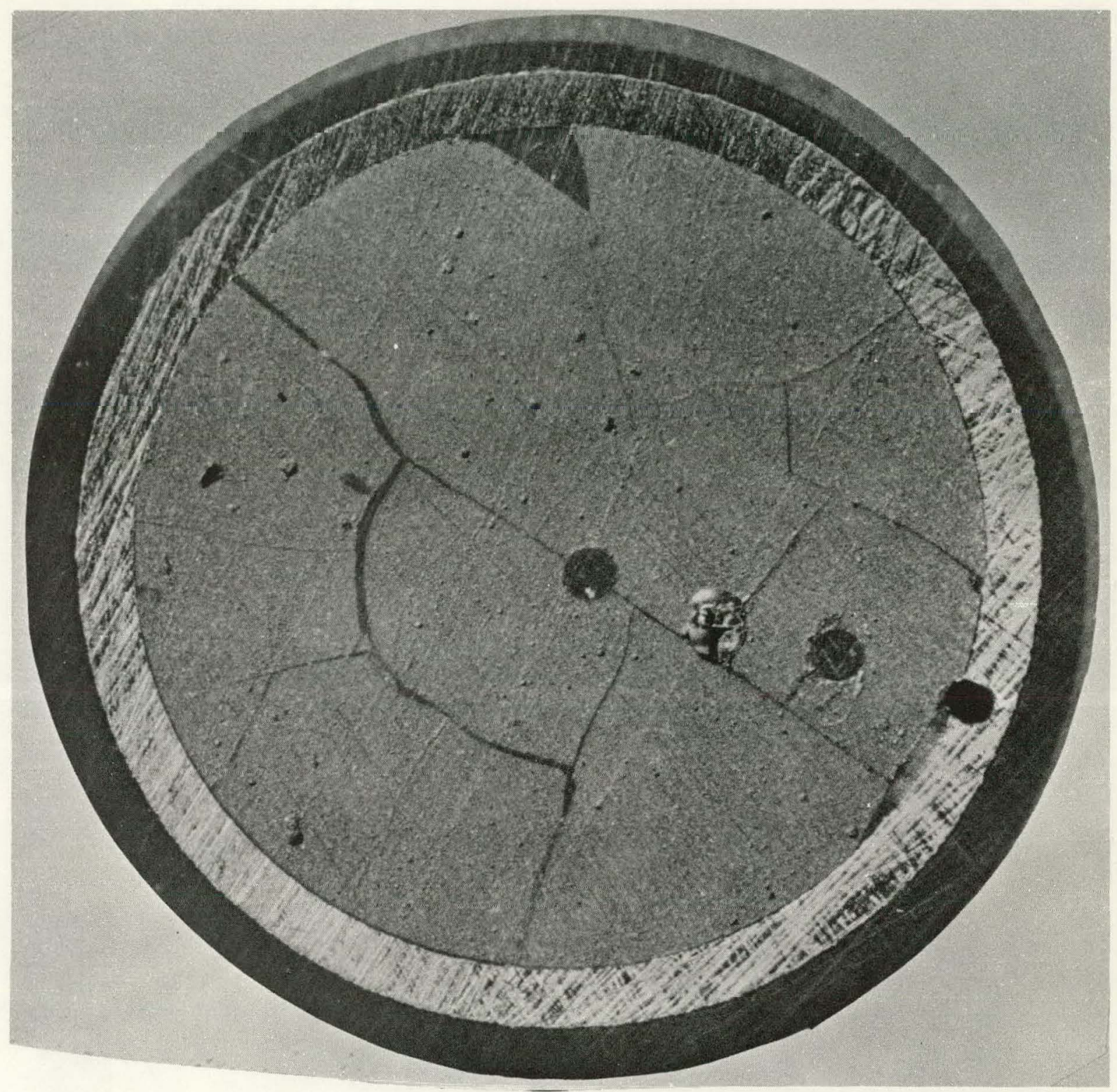

NEG. No. 9128-05

10X

SAME SECTION AS IN NEG. No. 9128-01

AFTER FURTHER POL ISHING AND

REMOVAL OF FISSION PRODUCTS

MIGRATION SAMPI FS. 


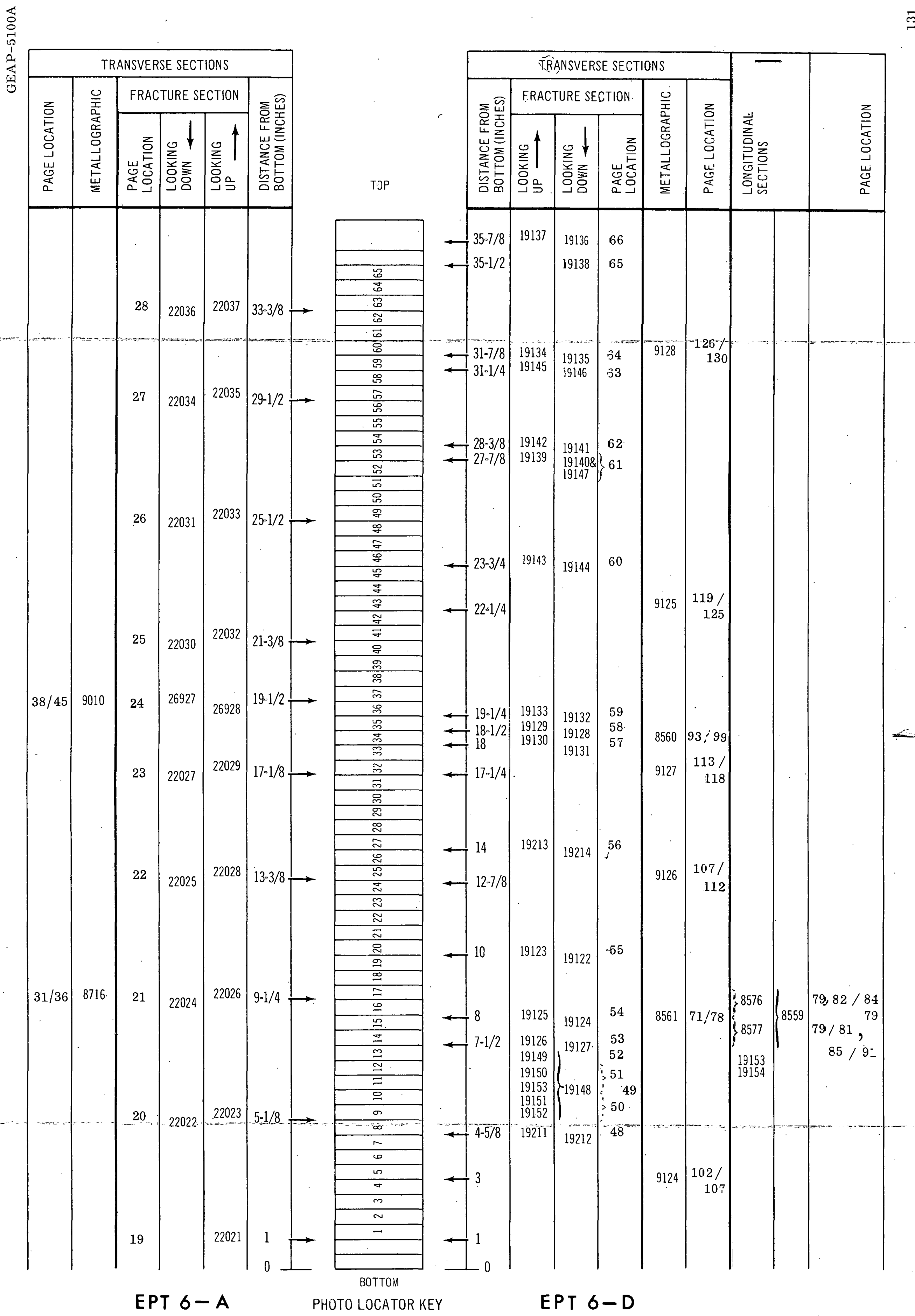

EPT 6-A PHOTO LOCATOR KEY

NOTE: DISTAACE MEASUREMENTS
ARE ACCURATE; PELLET ARE ACCURATE; PELLET.
LOCATION IS APPROXIMATE.

SJALE 1:3.114 
GEAP-5100A

\section{ACKNOWLEDGEMENT}

The authors would like to express their appreciation to R. E. Smith and W. V. Ketron for the excellent metallography, to D. H. Coplin for the data reduction and analysis, to F. R. Hubbard for assembling the report material, and to D. R. Eldredge for editorial and publication services. 
W. H. Brummett, Jr.

U.S. Atomic Energy Commission

San Francisco Operations Office

2111 Bancroft Way

Berkeley, California

Office of For eign Activities

U.S. Atomic Energy Commission

Division of Reactor Development

Washington 25 , D. C.

Fuels and Materials Development Branch

Nuclear Technology

U.S. Atomic Energy Commission

Division of Reactor Development

Washington 25, D. C.

Reports and Statistics Branch

U.S. Atomic Energy Commission

Division of Reactor Development

Washington 25, D. C.

Water Reactors Branch, Civilian Reactors

U.S. Atomic Energy Commission

Division of Reactor Development

Washington 25, D. C.

Water Systems Project Branch

Army Reactors

U.S. Atomic Energy Commission

Washington $25, \mathrm{D}$. C.

U.S. Atomic Energy Commission

Director, Reactor Engineering Division

Chicago Operations Office

9700 South Cass Avenule

Argonne, Illinois

Mr. Robert Macherey

Argonne National Laboratory

9700 South Cass Avenue

Argonne, Illinois

Babcock and Wilcox Company

Atomic Energy Division

P.O. Box 1260

Lynchburg, Virginia

U.S. Atomic Energy Commission

Liaison Office

Scientific Representative

Chalk River, Ontario 
Mr. William D. Manly

Oak Ridge National Laboratory

P. O. Box X

Oak Ridge, Tennessee

Mr. E. A. Evans

Hanford Atomic Power Operation

General Electric Company

Richland, Washington

Mr. J. M. West

General Nuclear Engineering Corporation

P.O. Box 245

Dunedin, Florida

Dr. R. H. Gale

Combustion Engineering, Inc.

Nuclear Division

Prospect Hill Road

Windsor, Connecticut

Dr. R. J. Creagan

Westinghouse Electric Corporation

Atomic Power Department

P. O. Box 355

Pittsburgh 30 , Pennsylvania

Mr. C. B. Graham

Allis-Chalmers Manufacturing Co.

Nuclear Energy Division

Milwaukee 1 , Wisconsin

Fiat

Joint U.S. - EURATOM Program

"Swaging of Uranium Dioxide" and "Uranium Dioxide Fuel Development

Sezione Energia Nucleare

Corso g-Marconi, $10 / 20$

Torino, Italy

Commissariat a l'Energie Atomique

Joint U, S, - EURATOM Program

"Sintered Uranium Oxide"

Direction des Relations Exterieures at des Programmes

Boite Postale 307

Paris 7, France

Battelle Memorial Institute

505 King Avenue

Columbus 1 , Ohio

Attention: R. F. Dickerson

Mr. C. Weber

Atomics International

P. O. Box 309

Canoga Park, California 
Mr. M. Raring

Pratt and Whitney Aircraft

CANEL

P. O. Box 611

Middletown, Connecticut

Mr. E. E. Hayes, Atomic Energy Division

E.I. DuPont de Nemours and Company

2430 Nemours Building

Wilmington, Delaware

Division of Technical Information Extension

Atomic Energy Commission

P. O. Box 62

Oak Ridge, Tennessee 